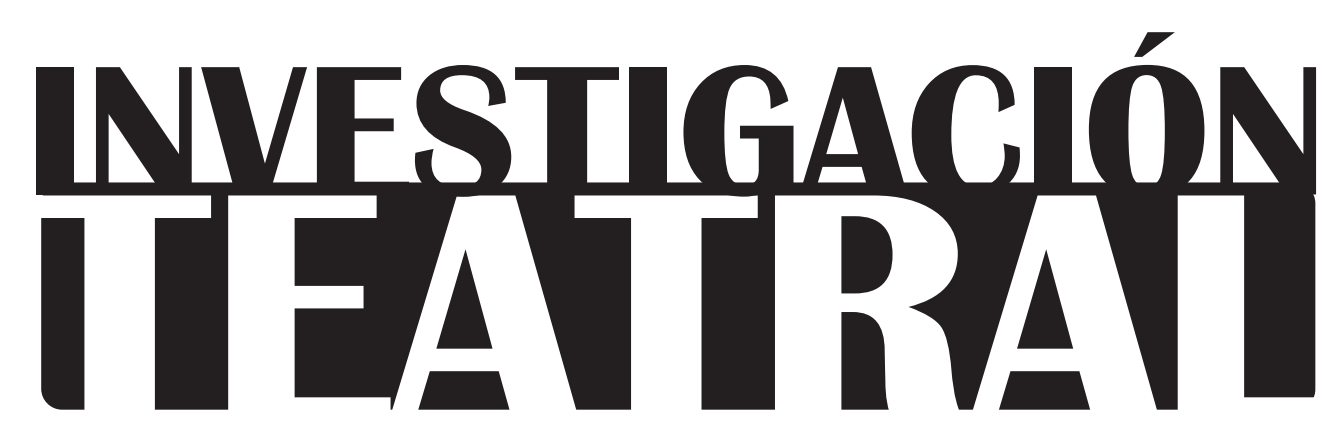

Revista de artes escénicas y performatividad
UNIVERSIDAD VERACRUZANA

Vol. 10, Núm. 15 abril-septiembre 2019 Segunda época

ISSN impreso: $1665-8728$ ISSN electrónico: 2594-0953

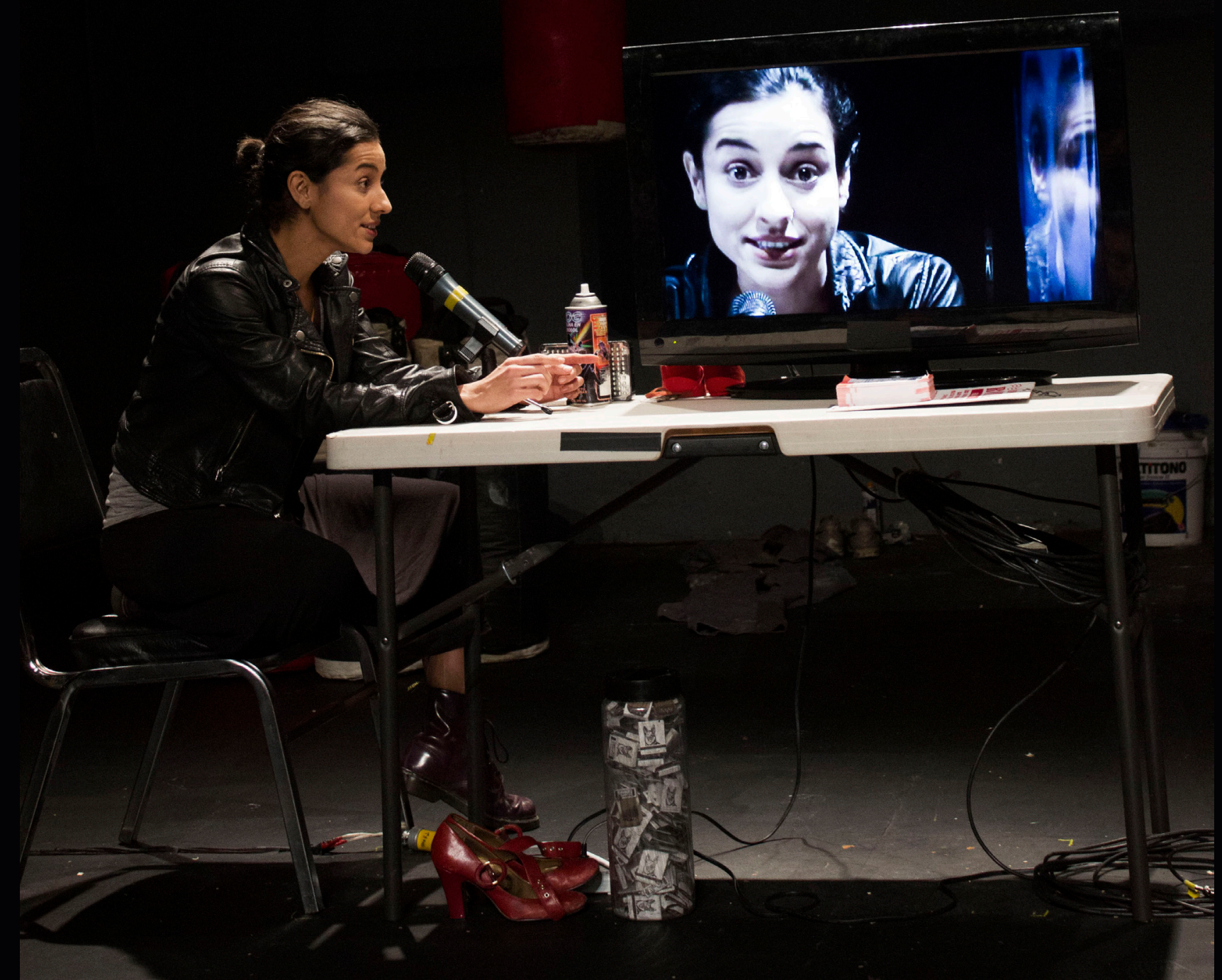




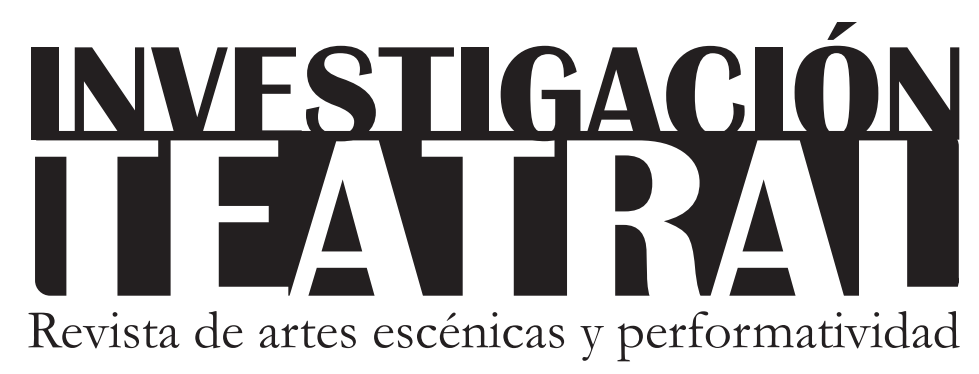




\section{INVESIGACIÓN}

Revista de artes escénicas y performatividad

Director: Antonio Prieto Stambaugh

(Facultad de Teatro y CECDA, Uv, México)

Editora: Gisel Amezcua (Dirección Editorial, UV)

Coeditor: Carlos Gutiérrez Bracho (CECDA, UV)

Coordinación técnica y de vinculación:

Verónica Herrera García

Asistentes de redacción y corrección: María Elena

Rivera Guevara e Indra Haritza Murillo Flores

\section{Consejo Editorial}

Elka Fediuk (CECDA, Uv, México)

Octavio Rivera (Facultad de Teatro, uv, México)

Domingo Adame (Facultad de Teatro, uv, México)

Arturo Díaz (Centro Nacional de Investigación

Teatral “Rodolfo Usigli”-INBA, México)

\section{Consejo Asesor}

José Ramón Alcántara (Universidad

Iberoamericana, México)

André Carreira (Universidad do Estado

de Santa Catarina, Brasil)

Nel Diago (Universidad de Valencia, España)

Jorge Dubatti (Universidad de

Buenos Aires, Argentina)

Josette Féral (Universidad de Quebec, Canadá)

Jacqueline Bixler (Virginia Tech University, E.U.A.)

Donald Frischmann (Universidad

Cristiana de Texas, E.U.A.)

Óscar Armando García (Universidad

Nacional Autónoma de México, México)

Daniel Meyran (Universidad de Perpignan, Francia)

Rodolfo Obregón (Centro Nacional de

Investigación Teatral "Rodolfo Usigli"-INBA)

Alejandro Ortiz Bullé-Goyri (Universidad

Autónoma Metropolitana-A, México)

Diana Taylor (Universidad de Nueva York, Instituto

Hemisférico de Performance y Política, E.U.A.)

Diseño editorial y composición

tipográfica: Héctor Hugo Merino Sánchez

y Cynthia Maribel Palomino Alarcón

Corrección de estilo: Agustín Elizondo (CITRU-INBA)

Imagen de la portada: Antígona González en Baños Roma. México, 2014. Fotografía de Ignacio Ponce.
Dirigir correspondencia a:

Revista Investigación Teatral, Centro de Estudios

Creación y Documentación de las Artes,

Universidad Veracruzana, Paseo de las Palmas 7,

Fraccionamiento Las Ánimas, Xalapa, Veracruz,

C.P. 91190, México. Tel. + 52 (228) 186-4314.

Correo electrónico: investigacionteatraluv@gmail.com

Versión electrónica:

http://investigacionteatral.uv.mx

(C) Universidad Veracruzana

Investigación Teatral. Revista de artes escénicas y performatividad, Vol. 10, Núm. 15, abril-septiembre 2019. Revista semestral del Cuerpo Académico Consolidado Teatro y el Centro de Estudios, Creación y Documentación de las Artes de la Universidad Veracruzana. Editor responsable: Dr. Antonio Prieto Stambaugh. Tel. (228) 8172134 y 18643 14. Reserva de derechos al uso exclusivo del título: No. 04-2013-032212535000-102, e ISSN 1665-8728 (impreso) 2594-0953 (electrónico), ambos otorgados por el Instituto Nacional de Derechos de Autor.

Revista publicada con la colaboración del Centro Nacional de Investigación, Documentación e Investigación Teatral "Rodolfo Usigli”.

El contenido de los textos publicados en esta revista queda bajo responsabilidad de sus autores. Se prohíbe la reproducción parcial o total de esta obra por cualquier medio, sistema y/o técnica electrónica o mecánica sin el consentimiento previo de la Universidad Veracruzana, y podrá hacerse siempre y cuando se cite la fuente incluyendo el título completo y textual del artículo, el nombre del autor, el nombre, la fecha y el número de la revista, así como el nombre de la institución editora. 


\section{Índice}

Presentación

Equipo Editorial. . . . . . . . . . . . . . . . . . . . . . 1

\section{ARTículos}

Un archivo de sombras.

Una mirada etnográfica sobre una pieza de Teatro Línea de Sombra

Rodrigo Parrini

Daniel González Marín

Alfadir Luna . . . . . . . . . . . . . . . . . . . . . . . . . . . . . 4 4

El diálogo afectivo con la tradición en el teatro chileno

reciente: una lectura de Neva, de Guillermo Calderón

Javiera Larrain George . . . . . . . . . . . . . . . . . . . . . . . . . . . 27

Metateatralidad y recepción en el texto

dramático del teatro español barroco

Ximena Gómez Goyzueta . . . . . . . . . . . . . . . . . . . . . . . . 55

¿Cómo será la muerte, ese cesar de sentir?

(En torno a Bodas de sangre, de Antonio Gades)

Nidia Vincent . . . . . . . . . . . . . . . . . . . . . . . . . . . . . . . .78

Meyerhold, entre la técnica extracotidiana de inculturación

y aculturación. Estudio desde la antropología teatral

Sergio Naranjo Velásquez . . . . . . . . . . . . . . . . . . . . . . . . . 103

\section{TESTIMONIO}

El canto vivo en el trabajo del actor.

Taller con el Workcenter de Jerzy Grotowski y Thomas Richards

Carlos Albarrán . . . . . . . . . . . . . . . . . . . . . . . . . . . . . . 122

\section{DOCUMENTO}

La sombra de la feria

Alain-René Lesage y Jacques Philippe d'Orneval

Traducción e Introducción: Alexis Álvarez Jácome. . . . . . . . . . . . . . . . . . . 136 
INVESTIGACIÓNTEATRAL

Revista de artes escénicas y performatividad

Vol. 10, Núm. 15

abril-septiembre 2019

\section{RESEÑA DE PUESTA EN ESCENA}

Lo que queda de nosotros, de Alejandro Ricaño y Sara Pinet

Wendoline Robles Hernández . . . . . . . . . . . . . . . . . . . . . . . . . . 154

RESEÑA DE LIBRO

¿Un mundo al revés? La tradición fársica en Hispanoamérica

Disa Villada Montaño . . . . . . . . . . . . . . . . . . . . . . . . . . . . . . . . . . . . . . 161

Los objetos vivos. Escenarios de la materia indócil

Marysol Arenas Cordourie . . . . . . . . . . . . . . . . . . . . . . . . . . . . . 165

Los payasos. Poetas del pueblo. El circo en México

Carlos Gutiérrez Bracho . . . . . . . . . . . . . . . . . . . . . . . . . . . 170

\section{RESEÑA}

La Muestra Estatal de Teatro de Chihuahua 2018: desmontajes y reseñas

Carlos Urani Montiel . . . . . . . . . . . . . . . . . . . . . . . . . . . . . . . 178

\section{IN MEMORIAM}

Arturo Meseguer Lima (1956-2019)

Francisco Beverido Duhalt. . . . . . . . . . . . . . . . . . . . . . . . . . . 194 


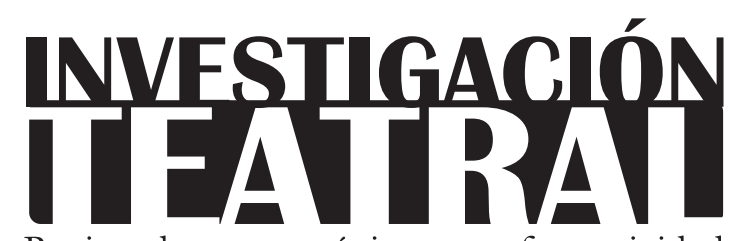

Revista de artes escénicas y performatividad

Vol. 10, Núm. 15

abril-septiembre 2019

Segunda época

ISSN impreso: 1665-8728

ISSN electrónico: 2594-0953

Universidad Veracruzana

\section{Presentación}

Equipo editorial Investigación Teatral*

\footnotetext{
* Universidad Veracruzana, México.

e-mail: investigacionteatraluv@gmail.com
} 


\section{Presentación}

E equipo editorial de Investigación Teatral desea compartir nuestra alegría ante el gran número de lectores que consultan actualmente la revista en su versión digital: las visitas desde diferentes partes del mundo rebasan las 1,000 mensuales. A partir de su inauguración hace ya cinco años, el portal de esta publicación ha sido consultado -hasta marzo de 2019- por más de 20,000 personas. Esto no es sino muestra del interés que tiene la investigación en artes escénicas a nivel global.

Iniciamos este número 15 con un texto escrito por el antropólogo Rodrigo Parrini, en colaboración con Daniel González Marín y Alfadir Luna, quienes reflexionan sobre los objetos de archivo utilizados por la compañía Teatro Línea de Sombras para producir la puesta en escena Baños Roma. Le sigue un texto de la investigadora chilena Javiera Larraín, sobre la obra Neva, del dramaturgo y director Guillermo Calderón. Este creador pertenece a lo que Larraín identifica como la nueva generación de la escena nacional chilena, con trascendencia internacional.

Por otro lado, Ximena Gómez Goyzueta, de la Universidad Autónoma de Aguascalientes, hace una reflexión sobre teatralidad y metateatro en el texto dramático del teatro español barroco. Asimismo, Nidia Vincent, de la Facultad de Letras Españolas de la Universidad Veracruzana, comparte su análisis sobre una coreografía que realizó el creador español Antonio Gades con base en Bodas de sangre, de Federico García Lorca. Vincent argumenta que el coreógrafo logró hacer una paráfrasis del texto teatral para proponer un nuevo discurso basado en lo corporal, lo espacial y lo musical. También presentamos un texto del investigador colombiano Sergio Naranjo Velásquez, quien analiza la propuesta de la biomecánica de Vsévolod Meyerhold desde la perspectiva de la antropología teatral 
de Eugenio Barba. De esta forma, el autor recupera para los creadores escénicos del siglo xxI nociones fundamentales sobre el entrenamiento y trabajo actoral.

En la sección "Documento", está el prólogo en monólogo de La sombra de la feria, pieza de la Comedia Francesa escrita por Alain-René Lesage y Jacques Philippe d'Orneval. Se trata de un texto de 1720 que Alexis Álvarez Jácome traduce por primera vez a lengua española para nuestra revista. El prólogo funciona como una obra cómica breve que se vale de personajes de la Comedia del Arte para ofrecer claves de la situación política, histórica y social que se vivía en el momento que fue escrita.

En la sección “Testimonio" incluimos el texto de Carlos Albarrán, estudiante de la Maestría en Artes Escénicas de la Universidad Veracruzana, quien nos relata su experiencia en el taller que el Workcenter de Jerzy Grotowski y Thomas Richards ofreció en la Ciudad de México el año pasado, siendo la primera visita a México que realiza este legendario Centro de trabajo fundado por Grotowski en Pontedera, Italia. Ahora, en 2019, se conmemoran 20 años del fallecimiento de Jerzy Grotowski (1933-1999), por lo que la revista Investigación Teatral se une con este testimonio a los actos que se realizan alrededor del mundo para reconocer que el legado del maestro polaco sigue vivo.

Continuamos con un grupo de cinco reseñas que abordan puestas en escena y novedades editoriales de gran interés. Cierra el volumen la semblanza-homenaje que el maestro Francisco Beverido hace del actor y promotor Arturo Meseguer, fallecido prematuramente cuando se desempeñaba como director general de Difusión Cultural de la Universidad Veracruzana. Además de haber sido protagonista importante del movimiento teatral de Xalapa desde los años 70 del siglo pasado, Meseguer realizó una incansable labor en pro de la expresión cultural y artística de estudiantes y creadores emergentes a través de los Festivales de Teatro Universitario. 


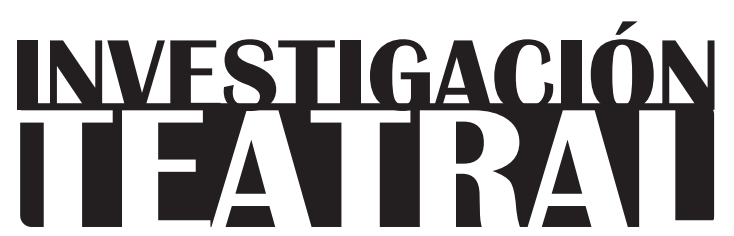

Revista de artes escénicas y performatividad

Vol. 10, Núm. 15

abril-septiembre 2019

Segunda época

ISSN impreso: 1665-8728

ISSN electrónico: 2594-0953

Universidad Veracruzana

\section{Un archivo de sombras. Una mirada etnográfica sobre una pieza de Teatro Línea de Sombra}

Rodrigo Parrini*

Daniel González Marín**

Alfadir Luna****

* Departamento de Educación y Comunicación, Universidad Autónoma Metropolitana, Unidad Xochimilco, México.e-mail: rodparrini@gmail.com

* Departamento de Lenguas/Departamento de Industrias Creativas, Instituto Tecnológico y de Estudios Superiores de Monterrey, México.

e-mail: gonzalez.jesus@itesm.mx

** Facultad de Artes y Diseño Plantel Xochimilco, Universidad Nacional Autónoma de México. Teatro Línea de Sombra, México. e-mail: alfadir.luna@gmail.com

Recibido: 25 de septiembre de 2018

Aceptado: 18 de diciembre de 2018 


\title{
Un archivo de sombras. Una mirada etnográfica sobre una pieza de Teatro Línea de Sombra
}

\section{Resumen}

Entre los materiales que Teatro Línea de Sombra reunió durante su investigación sobre "Mantequilla” Nápoles (boxeador retirado que fundó un club de boxeo en Ciudad Juárez) para producir una de sus piezas emblemáticas: Baños Roma (2013), hay una colección de fotos de rostros sin nombre y otra de credenciales con nombre, pero sin rostros, que pertenecieron a los socios de ese gimnasio. Estos materiales nos sirven para pensar y analizar lo que llamaremos un archivo de sombras, es decir, el registro de siluetas y sujetos cuyos destinos desconocemos, pero también los materiales y las estrategias para reactivar una presencia mediante los lenguajes del teatro. Un archivo de sombras guarda la imagen, pero pierde el destino; por eso, sería un archivo de dispersiones (personales, históricas y estéticas).

Palabras clave: archivo, etnografía, fotografía, teatro, violencia, Ciudad Juárez, México.

\section{An Archive of Shadows. An Ethnographic Perspective on a Piece by Teatro Línea de Sombra}

\begin{abstract}
This article analyzes two sets of materials collected by Teatro Línea de Sombra during their research on "Mantequilla Napoles", retired boxer and founder of a boxing gym in the border city of Ciudad Juarez, to produce the piece Baños Roma (2013). The collection of photos of unidentified faces, and the ID cards with name but without a face of former gym members, conform an archive of shadows, a record of silhouettes and subjects whose fates are unknown, but whose presence can be reactivated through the language of theater. The archive safeguards the image, but loses its destination. It constitutes, in a way, a file of dispersions (personal, historical, and aesthetic).
\end{abstract}

Keywords: Archive, ethnography, photography, theater, violence, Ciudad Juarez, Mexico. 


\section{Un archivo de sombras.}

\section{Una mirada etnográfica sobre una pieza de Teatro Línea de Sombra ${ }^{1}$}

Dice la verdad/quien dice la sombra. Paul Celan

A

finales de 2012, la compañía Teatro Línea de Sombra (TLS) viajó a Ciudad Juárez para investigar la vida del boxeador "Mantequilla" Nápoles y la historia del club de boxeo que él administraba allí: el gimnasio Roma. En ese lugar encontraron, entre muchas otras cosas, una colección de fotos de rostros sin nombre y otra de credenciales con nombre, pero sin rostros, que pertenecieron a sus socios. A partir de esos y muchos otros materiales, TLS creó una pieza que se titula Baños Roma-el nombre del recinto donde se encuentra el gimnasio y que fue un espacio de recreación para las familias durante varias décadas $-{ }^{2}$

1 Este artículo se realizó con apoyo del Fondo Nacional para la Cultura y las Artes, a través del Programa de Fomento a Proyectos y Coinversiones Culturales 2017.

2 Línea de Sombra propone, en su sitio web, la siguiente sinopsis de la pieza: "Baños Roma se originó como una exploración literaria que condujo a la búsqueda de José Ángel “Mantequilla” Nápoles, un ex-campeón mundial del boxeo que vive en Ciudad Juárez. La pieza se elaboró como una conjetura sobre algunos aspectos de la realidad social y política mexicana que se ubica lejos de la construcción verídica de los acontecimientos. El interés de la pesquisa se centró en intentar volcar la imaginación en un orden desde donde fuera posible dotar de sentido ficticio al presente incomprensible y ominoso. El trabajo puede entenderse como una deriva que narra lo que les sucedió a un grupo de colaboradores de la compañía TLs mientras 
INVESTIGACIÓNTEATRAL

Revista de artes escénicas y performatividad

Vol. 10, Núm. 15

abril-septiembre 2019
Un archivo de sombras

Rodrigo Parrini, Daniel González

Marín, Alfadir Luna

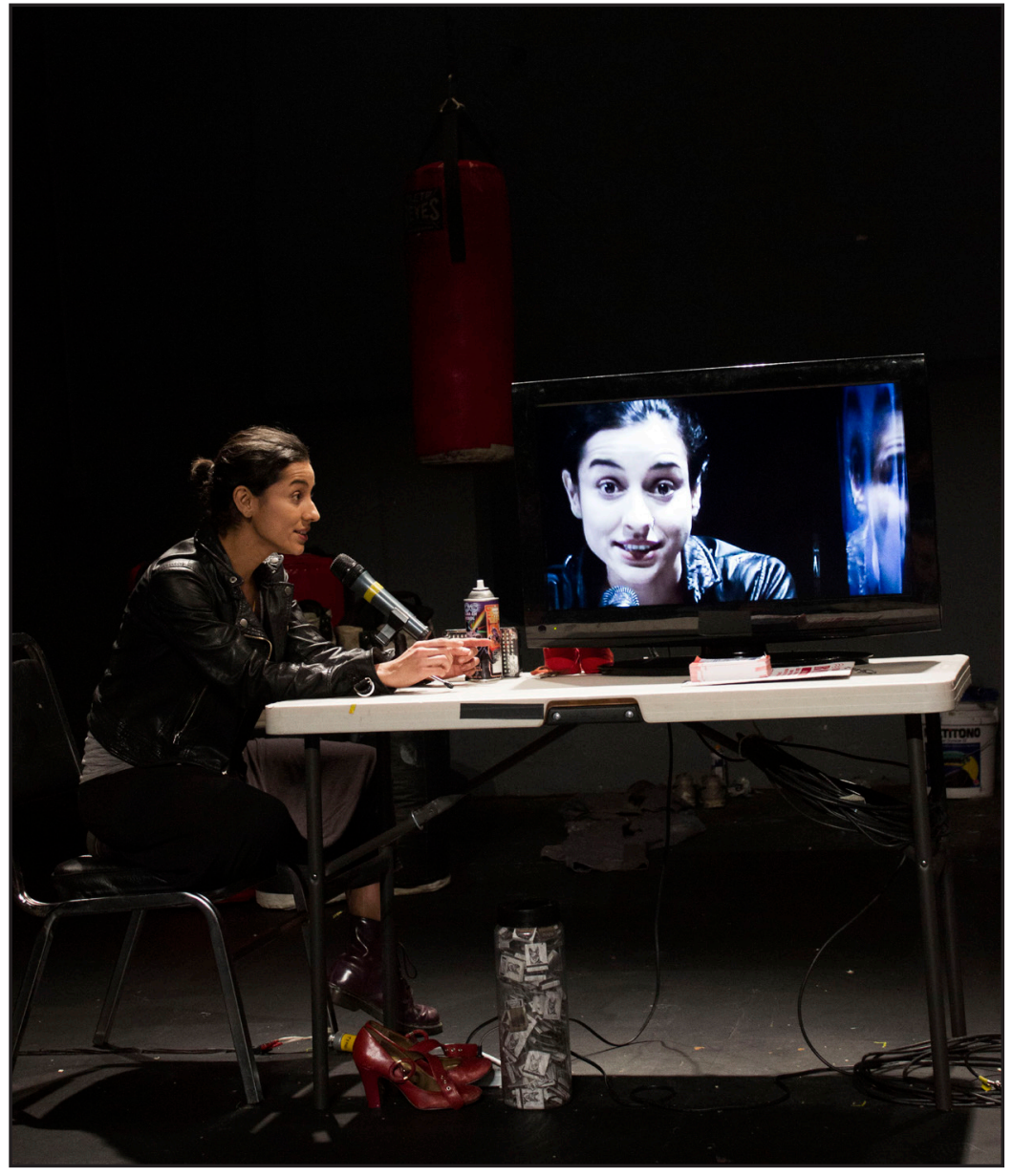

Antígona González en Baños Roma. Teatro El Milagro, Ciudad de México, México, 2014. Fotografía de Ignacio Ponce.

En este artículo intentamos dar cuenta de ese archivo de rostros y nombres disjuntos desde una perspectiva arqueológica y etnográfica. Cuando la compañía visitó la ciudad fronteriza, la urbe experimentaba uno de los periodos más violentos de su historia; los asesinatos acaecidos en esos años se contaban por miles. ${ }^{3}$ El centro de la ciudad era un lugar

buscaban a un ex-boxeador en Ciudad Juárez, quien, veinte años antes, entrenaba jóvenes en un lugar conocido como los Baños Roma" ("Baños Roma” párr. 1).

3 La violencia en Ciudad Juárez ha sido múltiple y polimorfa. Aunque desde finales de la década de los ochenta del siglo pasado comenzaron a divulgarse crímenes en contra de mujeres, predominantemente trabajadoras de las industrias maquiladoras asentadas en la región desde la década de los cuarenta (Martínez, Ciudad Juárez), es a partir de 1993 que la enumeración fue elaborada por fuentes oficiales. Entre 1993 y 1998 se registraron mil 465 homicidios, de los cuales 198 fueron de mujeres (Monárrez, "La cultura 
abandonado y el antiguo gimnasio, administrado por una de las glorias del boxeo mexicano de los años setenta del siglo pasado, estaba en ruinas. Estas fotos y otros objetos e imágenes que TLS reunió forman parte de las huellas materiales de un proceso de creación artística, pero también de la historia social y visual de la ciudad. ${ }^{4}$

Las fotos y las credenciales que nos interesan estaban en los cajones de los escritorios del gimnasio y alguien de la compañía las tomó y embaló. Algunas de ellas se utilizaron en el montaje y otras quedaron guardadas en el estudio del grupo, entre muchos otros objetos. Los integrantes de la compañía se han preguntado en repetidas ocasiones por el destino de quienes aparecen retratados en esas pequeñas imágenes, así como por el rostro de los nombres escritos en unas credenciales de cartón. Es una pregunta-fantasma que recorre la pieza teatral, sin que se explicite, y que orienta nuestra investigación. Es una interrogación que no buscamos responder, pero cuyas repercusiones exploraremos. Ese archivo, que sólo se conserva por un gesto de TLS, se conformó en un tiempo en que otros rostros se disipaban y cuando se exacerba en el país la relación entre violencia y desaparición. No es necesario que ambos fenómenos estén vinculados para que podamos pensar ese momento histórico y estético en el que las imágenes se transforman en un registro singular de la violencia o la ausencia (Diéguez, Cuerpos sin duelo). Desconocemos el destino de quienes fueron fotografiados, pero sabemos que esas imágenes se tomaron en una época particularmente cruenta.

Si fuera correcta nuestra lectura de una pregunta-fantasma que merodea la pieza, pero también la historia de Juárez, el archivo que nos interesa es uno de inquietudes y sombras, antes que de objetos y documentos. Pensamos un archivo de sombras como el registro de siluetas y sujetos cuyos destinos desconocemos, pero también de los materiales y las estrategias para reactivar una presencia. Es decir, si bien TLS no conoció a quienes fueron retratados y cuyas fotos quedaron almacenadas en algún escritorio de Baños Roma, en la pieza reaviva su presencia mediante una pregunta no sólo por las imágenes, sino también por el destino colectivo que se juega en ese gimnasio. ${ }^{5}$

del feminicidio en Ciudad Juárez"). De acuerdo a Molly Molloy, abogada y periodista que a través del sitio web Frontera List ha llevado un recuento pormenorizado de los homicidios en la región fronteriza, entre enero de 2007 y octubre de 2012 ocurrieron 11 mil 114 asesinatos. Pero 2010, hasta el momento, representa el año más cruento con 3 mil 622 asesinatos ("Yearly Death Tolls in Ciudad Juárez").

4 TLS acopió los insumos que configuraron el montaje de Baños Roma en un año en el que la violencia disminuyó (803 homicidios), pero, de acuerdo con testimonios de sus integrantes, gravitaba sobre ella un aura fantasmal.

5 El archivo está constituido por 276 fotografías: 10 mujeres y 266 hombres, mayormente adultos jóvenes y adultos de mediana edad, en ambos casos, y 185 credenciales: 27 con foto y nombre; 147 con nombre, pero $\sin$ foto; 10 en blanco; 1 con foto, pero sin nombre. 
En un momento de la obra, dos actores apilan las fotos sobre una credencial del gimnasio; una cámara graba en vivo ese ejercicio y lo proyecta en una pantalla y, finalmente, muestran el fragmento de una entrevista al boxeador ya retirado en la que dice "yo ya no existo" (Vázquez párr. 6). ${ }^{6}$ El boxeador, que fue una celebridad deportiva y mediática, se interpreta a sí mismo como una sombra. Un proceso de deterioro cognitivo y neurológico confirma esa lectura. En esa medida, el destino del entrenador del gimnasio, las fotos y las credenciales recopiladas así como la ciudad consumida por la violencia parecen compartir algunos rasgos. La pieza elabora una silueta de esa encrucijada personal y colectiva.

\section{Etnograf ía de un archivo}

Este artículo se enmarca en una investigación multidisciplinaria que busca explorar y pensar los archivos que TLS reunió para diseñar y montar dos piezas sobre Ciudad Juárez: Baños Roma (2013) y La Brisa (2016). ${ }^{7}$ Para plasmar ambas propuestas, TLS trabajó con materiales diversos: fotografías, videos, entrevistas, dibujos, objetos, mapas, entre otros. Ambos archivos constituyen documentos históricos sobre esa ciudad, que experimentó transformaciones radicales en las últimas décadas: archivos del desierto sobre el que se extiende la urbe, pero también de la violencia, los éxodos, las pérdidas, los pequeños esfuerzos, la vida cotidiana, el paisaje urbano. Los leeremos como archivos etnográficos de una ciudad y sus habitantes; del teatro como forma de mirada y estrategia de elaboración estética de la experiencia histórica; de los avatares de una sociedad y de las transformaciones de una urbe. ${ }^{8}$

6 La nota describe la situación del boxeador como "el ascenso y la estrepitosa caída de un ídolo" (Vázquez párr. 4). "Mantequilla" Nápoles, añade el periodista, "sobrevive de clases que imparte a jóvenes en un destartalado y triste gimnasio de Ciudad Juárez, Chihuahua" (ibídem); luego, agrega que el ex campeón "no quiere tocar el tema de su situación actual. Es orgulloso. De hecho odia hablar con prensa porque, asegura, lo ha tratado mal y rehúsa cualquier pregunta. 'No, no me interesa hablar. No de mí ni de lo que hago. Eso ya pasó, lo que hice ahí quedó... yo ya no existo', dice tajante durante una entrevista” (párrs. 5-6).

Si bien en este texto nos centraremos en una pequeña parte del archivo de Baños Roma, ambas piezas están ligadas geográfica y cronológicamente. En los viajes que los integrantes de TLs hicieron a Juárez conocieron la historia de "La Brisa", un bar fundado por activistas feministas y trabajadoras sexuales retiradas que fue, durante los años noventa, un punto de reunión de los artistas e intelectuales que circulaban por esa ciudad fronteriza. A finales de esa década, desconocidos quemaron el bar. colecta durante sus estancias y, a la postre, se integran a las puestas en escena. Pero incluso aunque no ocurriera esto último, el archivo se convierte en un umbral que delimita formas de entender el teatro y el mundo que lo circunda o acomete. Acerca de los archivos de la compañía Odin Teatret de Eugenio Barba, 
INVESTIGACIÓNTEATRAL

Vol. 10, Núm. 15

abril-septiembre 2019
Un archivo de sombras

Rodrigo Parrini, Daniel González

Marín, Alfadir Luna

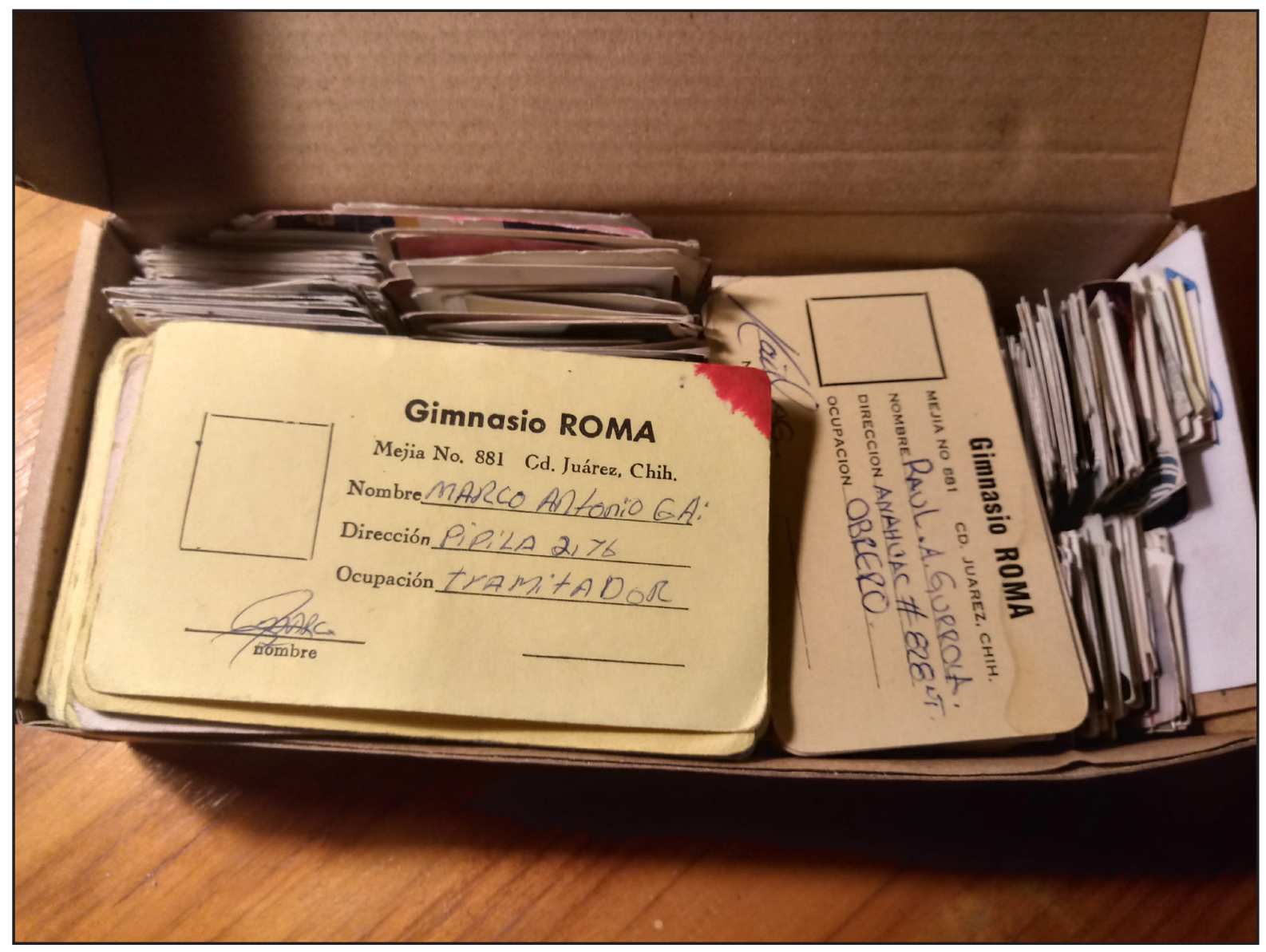

El archivo en una caja de cartón. Archivo Teatro Línea de Sombra. Fotografía de Rodrigo Parrini.

Nos interesa trabajar con una noción de archivo que recupere tanto su lugar en la producción del arte contemporáneo (Guasch, Arte y archivo; Foster, "An Archival Impulse"; Spieker, The Big Archive), como en la constitución de discursos sobre una ciudad, un proceso histórico y algunas formas de vida. El archivo no constituye solamente el conjunto de materiales que persisten de un espacio o un tiempo determinados, sino también la estrategia de lectura que reconoce las persistencias no resueltas y los sedimentos invisibles que conforman el presente (Agamben, Signatura rerum). El trabajo de TLS con esos materiales

que Mirella Schino ha organizado, la investigadora afirma que "conservan las huellas de una infinita gama de posibilidades en lo que respecta a las relaciones creativas, las estrategias de actuación y las diversas actividades del teatro-laboratorio" (422). 
permite equiparar a los creadores con los etnógrafos, en el sentido dado por Hal Foster (El retorno de lo real). Es decir, investigadores que se fijan un propósito, intervienen en un campo, seleccionan y producen una obra a través de un montaje.

\section{Tráfico de archivos}

Investigar este archivo de imágenes, tal cual lo consiguió TLS, implica adentrarse en una franja sombría donde la pregunta por esas vidas no tendrá respuesta. También supone interrogar los modos en que unas fotos guardan la existencia de alguien, aunque no sepamos su nombre. Sombra y presencia son los bordes de estos archivos. Si bien el archivo de fotos y credenciales es materialmente distinto a la pieza, el archivo de sombras y presencias es producido por ella.

¿Pueden los mismos materiales y los mismos objetos producir y sustentar dos archivos distintos? En el club de boxeo se plasmó un archivo, con el rostro y los nombres de sus clientes. El otro, lo produjo una compañía de teatro, pero ya no se trata de esos clientes, sino de sus sombras; ya no es el "campeón", sino alguien que no existe. Ese segundo archivo surge cuando los materiales del primero desaparecen; no es el registro provisional de unos datos, sino el espacio de unas presencias que emergen en la escena como imágenes apiladas de vidas desconocidas. Podemos mirar muchas veces esos rostros, pero su interpelación está vedada. Esas imágenes guardan un estatus de imagos aunque hayan perdido sus genealogías y sus historias (Didi-Huberman, Pueblos expuestos 55), como si fueran a la vez definitivas y evanescentes. Son rostros de un extravío que no atañe, en primera instancia, a quienes fueron fotografiados. Somos nosotros, sus testigos, quienes podemos preguntarnos por sus destinos, como si el archivo surgiera justo en ese instante cuando una mirada se encuentra con un objeto y lo interroga: ¿de quiénes son estas fotos?, ¿qué rostros tenían estos nombres?

El archivo de sombras no corresponde sólo al conjunto de fotos y nombres de desconocidos, sino al encuentro entre una mirada y una pregunta y algunos materiales que no pueden decir otra cosa que su pura presencia. La arqueología, dirá Agamben (Signatura rerum), es una interrogación sobre el presente: el tiempo que está allí, pero por develarse. El archivo es aquello que el presente no capta de sí mismo y que lo excede.

¿Cuál es el presente de ese archivo? ¿El momento en que se tomaron las fotos o se registraron los nombres? ¿O ese otro instante cuando TLS encontró todo eso en unos cajones? ¿O su proyección en una pantalla durante la pieza? ¿Este mismo instante en que escribimos sobre él? Pensamos que el archivo pertenece a un tiempo no resuelto y tal vez irresoluble. No se trata sólo de que el archivo contenga tiempos heterogéneos, sino ante todo de la 
imposibilidad de situarlo en un tiempo -como si constituyera una heterocronía singular(Rufer, "El archivo").

Cuando "Mantequilla" Nápoles dice que él ya no existe, anuncia una disyunción radical de sus tiempos: el presente sombrío frente a un pasado de gloria. En su caso, la muerte surge como un deslizamiento donde los momentos contrastan de forma irremediable. Una heterocronía subjetiva inquieta al boxeador, que no puede reconocerse en su estado actual. Algo de sí está escindido de su presente; esa inexistencia actual resguarda lo que alguna vez existió, como si dijera "yo fui, ahora no soy". En esa medida, su archivo personal corresponde con su pasado biográfico y el recuerdo constituye la única relación consigo mismo, en un radical borramiento del presente.

Pero, por otra parte, esas fotos y credenciales buscan un tiempo en el que las vidas coincidan con los rostros y los nombres con las identidades. Ese archivo de sombras contendría una promesa temporal y formal: un instante cuando se ensamblaran las piezas sueltas y la luminosidad disipara una oscuridad relativa.

En La cámara lúcida, Roland Barthes sostiene que "la fotografía repite mecánicamente lo que nunca más podrá repetirse existencialmente" (27-28). Ese espacio entre repeticiones, entre lo mecánico y lo existencial, será un intervalo de disipación; antes que una garantía para la memoria, será entonces el anuncio de lo inexistente. Y al ver esas fotos, ya resueltas mecánicamente, nosotros reprodujimos, en alguna medida, esa distancia, esa fisura entre un tiempo del acto (mecánico) y otro de la existencia. El archivo de sombras será, entonces, justo el interludio entre un tiempo y otro, entre lo repetido y lo existente. No guarda unos materiales, sino que registra esa disyunción radical que agita nuestra mirada, pero también interroga al futuro. ¿Es posible contemplar el rostro de alguien en una fotografía, especialmente si no lo conocemos, y evitar preguntarnos por su existencia? Es como si la imagen nos trajera la vida -no sólo el semblante-, y una solidaridad secreta nos vinculara con ella. En la constitución del archivo de sombras cabría argumentar, con Barthes, que la fotografía se anula como médium para "no ser ya un signo, sino la cosa misma" (83). No hay nada más que esas imágenes, su misterio y las preguntas que suscitan.

En la lectura que Didi-Huberman hace de los escritos sobre fotografía de Barthes, el punctum, como una unidad temporal, "no permanece en la dimensión abstracta de un pasado cumplido, resuelto; al contrario, produce a la vez el allí (presencia) y el en otra parte (separación) del 'presente' y de lo 'diferido'" (Didi-Huberman, Pueblos en lágrimas 141). Eso, dice el historiador del arte, "hace temblar el tiempo de la pose, entre la detención y la toma, el pasado y el deseo" (ibídem). ¿Se puede imaginar un archivo que emerja en el tiempo de la pose, justo en el instante indefinido, pero fundamental, de la detención y la toma? ¿Qué temporalidades registraría ese archivo si lo desplazáramos desde el entonces de la toma al ahora de la imagen? ¿Por qué, en el pensamiento de Barthes y Didi-Huberman, el 
pasado y el deseo están separados como si el primero correspondiera, en alguna medida, a la detención y el otro a la toma?

Vemos unos rostros detenidos en la imagen, opacos en sus deseos, pero transparentes, en cierto modo, en la toma misma que los capturó. Quizás ellos no pertenezcan a esa dimensión abstracta de un pasado cumplido y aún se muevan entre un allí y un en otra parte. Por eso, dice Didi-Huberman, la fotografía sería "una cuestión de espectros", pero también de "resurrecciones", según Barthes. ¿Puede una imagen registrar espectros y también anunciar resurrecciones? ¿Cómo leer el tiempo irresuelto del espectro y el venidero de la resurrección? Supongamos que un archivo de sombras contiene o guarda tiempos tales, ¿se podría decir que es un archivo?, ¿allí está?, ¿lo buscaríamos en el tiempo sido de los espectros o en el venidero de las resurrecciones? Eso inquieta en estas imágenes, un desplazamiento temporal que no podemos sosegar. La pregunta-fantasma que identificábamos al inicio también es una promesa. No sólo se trata de avizorar -¿dónde están?--, sino también de saber - ¿qué habrá sido de ellos?-

Un archivo de sombras guarda la imagen, pero pierde el destino. Por eso, sería un archivo de dispersiones (personales, históricas, estéticas). En alguna medida, esas fotos de personas que no conocemos, cuyos nombres son una incógnita, tienen el aura de la desaparición, aunque ignoremos el estatus de los retratados. Por eso, Barthes vincula de manera tan íntima a la muerte y a la fotografía.

El archivo con el que trabajamos es frágil y débil. No surge de la voluntad estatal de conservar algunos materiales o de un afán académico por clasificar y embalar. En él hay algo casual, pero también sistemático; un ejercicio de conservación mínimo que facilitó que esas imágenes llegaran hasta nosotros. Quedaron guardadas en un cajón, aunque podrían haberlas tirado a la basura. Luego, alguien de TLS las encontró y se las llevó. Formaron parte de los acervos fotográficos que sirvieron para crear Baños Roma, aunque de modo tangencial. Posteriormente, fueron embaladas en una bolsa de plástico, casi transformadas en desechos, y nosotros las recuperamos para poder producir el archivo de la pieza. Un archivo de sombras también registra las condiciones de su producción y los avatares de su existencia. Esas imágenes, que fueron primero fotos de credenciales deportivas, luego recursos para crear una pieza escénica (ya alejadas de su contexto de producción y uso) y, ulteriormente, convertidas en material etnográfico y visual de una investigación sobre el teatro, la violencia y el archivo, se desplazan por distintas formas de una recolección y sólo entran en el campo académico cuando son leídas como registros significativos de un proceso histórico.

En esta última etapa, intentamos reconectar el contexto con las imágenes para entender esos rostros, aunque desconozcamos sus identidades. Tal vez un escenario social y político de desapariciones nos permite pensar la ausencia como un síntoma más agudo que la falta 
de nombre; quizás como el destino de miles de vidas contemporáneas a las nuestras. En esa medida, este archivo no ha encontrado su lugar y quizás no pueda hallarlo nunca. Es un archivo siempre desplazado, en el que nuevas preguntas generan otros deslizamientos y nuevos contextos lo densifican de modos singulares. Es un archivo abierto e inconcluso. No hay una autoridad que le dé un contorno, no adquiere un estatus claro como material histórico o artístico, pasa de unas manos a otras sin que pueda decidir(se) su destino. Quizás se transformará, a la larga, en basura y las fotos se perderán para siempre. Un motivo de conservación es una treta institucional, pero la materialidad de las imágenes padece el paso del tiempo de modo ineluctable. Las fotos se borran, como el mismo boxeador entra en las penumbras de su mente. El archivo, visto desde esta perspectiva, está constituido por el tránsito entre sujetos y contextos diversos, que guardan estos materiales provisionalmente, porque parece que su futuro se debe sobre todo a las asociaciones que concita y no al valor de sus materiales. Es un archivo de préstamos y apropiaciones. ${ }^{9}$

Carl Einstein sostenía que la imagen era un futuro en potencia, "un intervalo alucinatorio"' (citado en Didi-Huberman, Ante el tiempo 307). Ese intervalo, en el que distintos sujetos imaginaron que aquellas fotos podían decir algo, y su futuro en potencia, dependen de la trama de movimientos que reubica a los materiales para que algunas intenciones se cumplan. Contiene ese rastro alucinatorio del que habla Einstein, una especie de verdad pendiente y una capacidad para instigar fantasías: las del boxeador, cuando guardó las fotos en un cajón (o de alguien que trabajaba en el gimnasio); las de TLS que las halló y movió; las nuestras, que las reencontramos e intentamos restituir su aura.

¿Son ésas las sombras? No sólo las imágenes anónimas y sin destinatario; también los usos del archivo, las intenciones que lo arman y desarman, que le otorgan una forma y también la deshacen. En esa medida, un archivo de sombras contendría, además de unas ausencias que no se pueden resolver, una multiplicidad de voluntades (intensas o difusas) que lo sostienen, pero también lo disuelven. Imaginemos que el archivo es, ante todo, la trama de sujetos y contextos, apropiaciones y pérdidas, movimientos y quietudes que experimenta determinada materialidad significante. Así, el archivo participaría de lo que Allan Sekulla llama "un tráfico de fotografías", que remite tanto al movimiento material de las imágenes como a las oscilaciones de sus sentidos (citado en Batchen 15). Si bien Sekulla localiza ese tráfico en las disputas de la cultura burguesa, nosotros quisiéramos pensar el movimiento geográfico entre Ciudad Juárez y Ciudad de México y, luego, los desplazamientos constantes de esas imágenes alrededor del mundo como

9 En los rostros fotográficos despojados de su carnet de identidad y en las credenciales con datos desprovistos de semblante, se juega una paradoja entre el sí mismo y el otro. Stoichita anota que, en la confusión entre sombra y reflejo, "la sombra representa el estadio del otro, el espejo, el estadio de lo mismo" (40). 
parte del montaje de Baños Roma en otras latitudes, pero también los deslizamientos de esos materiales desde los cajones a las bolsas de supermercado y luego a una caja de cartón para resguardarlas. Por último, podríamos añadir el tráfico que ocurre en las repetidas transformaciones del sentido de las imágenes: como apoyo visual en una credencial, como objeto escénico en una obra de teatro y como material etnográfico en una investigación social.

Podemos pensar, entonces, el archivo como el espacio de un tráfico múltiple que no termina de suceder. Desde esa perspectiva, sería más importante conocer los puntos y las rutas de un movimiento, que los objetos en tránsito. Podemos imaginar, en consonancia, que un archivo como espacio de tráficos materiales y significantes puede contener muchos objetos, discursos, hechuras, imágenes, pero que su forma estará definida por las coordenadas de los trayectos que consienta (o facilite e imagine) y los parámetros en los que éstos ocurran. Por ejemplo, este archivo admitía muchos desplazamientos y no necesitaba producir una localización definitiva. Nuestros usos forman parte del tráfico, no lo suspenden. Sin embargo los parámetros no están decididos de antemano y, más bien, emergen localmente a partir de los usos que se le otorgan al archivo: en el gimnasio, usos identificatorios; en el teatro, artísticos; en la investigación, hermenéuticos.

\section{En los bordes del archivo}

Al retomar un bello texto de Foucault, La vida de los hombres infames, Giorgio Agamben se pregunta dónde están las vidas que aquel autor había encontrado en bibliotecas y otros archivos, apenas visibles para la historia salvo en ese encuentro tal vez fortuito, pero definitivo, con el poder. Agamben responde que no están en "las lacónicas notas que registran su presencia en el archivo de la infamia", pero tampoco "fuera del archivo, en una realidad biográfica de la cual no sabemos literalmente nada" (Agamben, Profanaciones 88). Esas vidas, escribe el filósofo italiano, "están en el umbral del texto en el cual han sido puestas en juego [...] al borde del archivo" (ibídem). ¿Podemos pensar un archivo como umbral o borde? Las vidas que nos conciernen, ¿también están localizadas ya no en el umbral del texto, pero sí en el de la imagen? Supongamos que esas fotos son bordes de un archivo: ¿qué nos muestran?, ¿qué límites se tocan en ellos? Vladimir Jankélévitch sostiene que si bien es espacialmente imposible y lógicamente impensable estar a la vez dentro y fuera, se puede estar en un umbral y "pasar una y otra vez del interior al exterior" (13). ¿El umbral es un límite? ¿Es el espacio o la instancia de un pasaje? ¿Una posibilidad real o imaginaria de transitar? Si esas fotos fueran bordes, ¿qué está en juego en ellas?, ¿qué es interior a la imagen y exterior a ella? 
Imaginemos que estas imágenes son un umbral: pegadas en una credencial servían para entrar a un lugar o dar cuenta de una pertenencia. Cuando las vemos ahora, entramos a través de ellas al gimnasio que "Mantequilla" Nápoles administraba y a la Ciudad Juárez de ese entonces. Sabemos de dónde vienen, por eso podemos intuir otras imágenes que rodearían a esas fotografías. Incluso, podemos convocar otras fotos del archivo que produjo TLS en torno a ese lugar, para crear nuevas coordenadas de lectura. Las imágenes del gimnasio en ruinas, luego restaurado por la compañía. Las fotos de un álbum que la esposa del boxeador recopiló sobre ellos y su familia, que muestran el mundo de Juárez desde los años ochenta del siglo pasado. Otras fotografías que los integrantes de TLS tomaron de la ciudad durante su residencia. Un rompecabezas de imágenes diversas de un mismo mundo. Algunas casuales, otras intencionales.

¿Cómo pensar un archivo de imágenes que se han separado radicalmente de los sujetos y los cuerpos que fueron registrados en ellas, pero que todavía son nuestros contemporáneos? Oscuridad y luz serían justamente los bordes de este archivo que se proyecta como una sombra, como efecto de ese juego de gradaciones de lo visible. Una sombra sería el resultado momentáneo de una relación entre luz y oscuridad. Si sólo hubiese oscuridad o luz no se formarían sombras. Entonces, cuando pensamos estas imágenes como archivos de sombras, debemos atisbar qué luces las iluminan y qué oscuridades las resguardan. ${ }^{10}$ La oscuridad del momento vivido, escribe Eduardo Cadava, "nos expone a lo que está más cerca, a lo que es más banal y más obvio: la oscuridad de nuestra experiencia cotidiana" (158). Este archivo, en sus tránsitos y desplazamientos, en la incertidumbre que porta y los destinos aciagos que contiene, en su radical fragilidad que no es distinta a la de tantas vidas, traza los bordes de las oscuridades históricas y políticas en las que habitamos; las materialidades violentas y evanescentes que nos rodean; los pactos que organizan la vida social, pero que no pueden ser escrutados. El archivo es, así, un borde político, no sólo estético. Jacques Rancière escribe que toda "batalla de ideas" es "una batalla de mundos percibidos y, así pues, una batalla de afectos" (269). ¿Qué mundos percibimos en estas imágenes?, ¿qué afectos están en juego en las fotos y sus transformaciones sucesivas, en las preguntas que no podemos responder, en los fantasmas que atraviesan la disyunción entre los rostros y los nombres, entre la vida y las imágenes o entre el teatro y la etnografía?

El archivo es un modo de percepción y una manera de distribuir lo visible. El momento de esas fotos es trivial y cotidiano, son retratos de bajo costo tomados sin mucho cuidado y rápidamente. Las imágenes resguardadas por TLS, ¿corresponden a un archivo público o son un álbum familiar que se perdió cuando los integrantes de la compañía se llevaron

10 Victor Stoichita escribe que "estudiar la sombra implica [...] un doble desafío, tanto frente a la representación colectiva positiva de la luz como ser absoluto, como frente a la dialéctica del claroscuro" (11). 
las fotos a otro lugar y las expusieron en otro régimen de uso y otro sistema de miradas? Cuando algunas de esas imágenes son proyectadas en una pantalla durante la pieza teatral, se vuelven públicas, pueden ser vistas por los espectadores. Pero no fueron tomadas con esa finalidad, eran apenas una especie de garantía visual para un nombre que quedaría con la persona retratada, bajo la forma de una credencial.

\section{Cajones oscuros y fragmentos de lo real}

¿Por qué sacar esas fotos de un cajón oscuro y tratar de construir con ellas un relato?, ¿cómo mirar esos rostros anónimos de los que nos hemos apoderado clandestinamente?, ¿para qué recuperar esas fotos de una bolsa de supermercado y especular sobre qué tipo de archivo constituyen?, ¿por qué quiere el teatro esas imágenes o para qué le sirven a la etnografía unas credenciales de cartón? Ordenamos todos esos materiales y tratamos de entender, por una parte, su genealogía en un mundo violento que produce borraduras sistemáticas antes que recuerdos ordenados; interrogamos, aunque sea por unos instantes, el estatus de esas fotografías y el destino de esos sujetos, como si la imagen garantizara la existencia de alguien y develara la presencia de una vida ante nuestros ojos, a pesar de la ausencia de otras pistas y otros datos, como si ver una imagen de ese tipo también fuera creer en ella. Pero, también, tratamos de comprender las intenciones de una compañía de teatro al tomar esos materiales y guardarlos, llevárselos a otro lugar y luego proyectarlos en las funciones de una pieza teatral; como si quisiera dar fe de unas existencias que le son ajenas y mostrar frente a otros ojos la mirada de esas personas y multiplicar así la confianza en lo que vemos, en la creencia o la certidumbre de que esos rostros son verdaderos y que las fotografías corresponden a vidas reales, aunque desconocidas, que debemos exhibir para recordar. Son gestos contra la muerte o el olvido que nos aseguran que podemos dar cuenta del otro, crear un relato de sus devenires, mostrar el mundo en que vivieron, citar sus palabras de oídas o inventadas, sacar a la luz -desde la oscuridad de los cajones- la inmensidad de las biografías o el tráfago infinito de las ciudades.

Este archivo es un gesto: tomar de unas gavetas las fotos, embalarlas y, después, mostrar algunas de ellas. $\mathrm{O}$ sacarlas de una bolsa y luego ordenarlas y pensar qué destinos se anuncian en esos rostros, las formas en las que el arte archiva y destruye, los modos en que la etnografía registra e interpreta. Un gesto que produce intervalos, hiatos en el uso de los objetos y nuevos desplazamientos de las materialidades en juego. Fotografías de fotografías, el archivo de sombras constituye, al parecer, un archivo de segundo orden que no guarda imágenes, sino sus reflejos; recopila gestos que luego se disolverán; un esfuerzo para retener la sutil destrucción de los papeles y los colores para explorar la misteriosa forma de las voluntades y los actos. 
Mirar con esperanza, pero también con impotencia, aquello que encontramos o que recopilamos. El archivo es un espacio de silencios y la bóveda donde nuestras elucubraciones labran tenues sonidos. El teatro, dice Genet, "debe ser la fête, una festividad dirigida a los muertos" (citado en Lehmann 125). Este archivo se conformaría con los restos de la fiesta y, en última instancia, con todo el teatro de Línea de Sombra, específicamente Baños Roma. Se archivan los restos de una fiesta peculiar, pues sucede como si la compañía llegara después de los fallecimientos y los entierros a ofrecer novenarios extravagantes, en los que funge como un deudo solitario que lamenta miles de muertes. Una fiesta a destiempo que no celebra ni la muerte ni la vida, sino que se desplaza por los recintos en ruinas -de la experiencia humana y la historia- para recoger los vasos, platos, serpentinas...

Y después del teatro, arriba la etnograf ía, como una disciplina en cierto modo forense ${ }^{11}$ que recoge restos que ya han sido recolectados y observa las imágenes de imágenes

11 En otro texto, uno de nosotros ha abordado una perspectiva forense del teatro y la etnografía, con un colectivo teatral distinto (Parrini, "Canto de Palomas"). El carácter forense de una pieza de Teatro Ojo, Canto de Palomas, nos interesó por su interrogación sobre las ruinas de un antiguo cine del centro de Guadalajara, convertido en centro cultural por parte del Ayuntamiento. En ese recinto convergían la muerte, una colonia de palomas, los vestigios de las grandezas de los antiguos cines de las ciudades mexicanas, una restauración estatal sin terminar y las inquietudes de un grupo de teatro. Si bien el contexto es distinto, avizoramos un gesto común en ambas piezas - Baños Roma y Canto de Palomas-mediante el cual el teatro interviene las ruinas de un espacio físico para preguntar sobre los restos de una historia nacional, local o personal. La materialidad sería una ruta de interrogación de la(s) vida(s) y los objetos, constituiría una forma singular de producir o reconstruir un testimonio, ya sea de lo que conocemos de primera mano (un gimnasio, un cine) o de lo que no podremos conocer jamás (la gloria de un recinto o de un boxeador). Ambas piezas exploran unas arquitecturas en ruina a través de estrategias estéticas y narrativas del teatro, a la manera -en otro sentido y con otras herramientas- de la arquitectura forense que entiende a las ruinas como "puntos de entrada desde los cuales son trazados ensamblajes de conexiones" (Weizman 92). A su modo, ambas piezas produjeron archivos singulares: más denso el de Baños Roma, evanescente el de Cantos de Palomas; no archivos de un registro, sino fragmentos de las ruinas interrogadas que sostienen a ambas obras como si se tratara de precarios ladrillos. El archivo no es el resultado de las piezas, sino que constituye las piezas mismas. Canto de Palomas sólo podía ser "representada" en el recinto donde se creó, no consideraba otro "escenario" en el que se realizara una repetición desterritorializada de la obra; Baños Roma tomó los objetos y los desplazó para convertirlos en fragmentos de una itinerancia y una dispersión espacial y estética. Desde esta perspectiva, la primera pieza se diluye en el espacio y comienza a formar parte del archivo que cita y sobre el que se funda; la segunda, en cambio, recoge el archivo y se lo lleva para poder repetir su sustracción/creación en otros espacios. Si tuviéramos que resumir, diríamos que el archivo de Canto de Palomas se incorporó a la pieza desde dentro para diluirla en sí mismo; el de Baños Roma habita a destiempo el montaje, trazando una tensión entre el acto de representar y el de archivar y, al contrario de Cantos, la pieza diluye en sí misma el archivo que produjo. Si este análisis fuera correcto, entonces el trabajo de Teatro Ojo estaría habitado 
que alguna vez fueron tomadas o apropiadas. Llega, definitivamente, en otro tiempo a preguntar por las temporalidades que ha producido un archivo, los afectos que suscitaron la fiesta y el teatro; a tocar la materialidad evanescente de unas fotografías. Si el teatro es una fiesta, la etnografía es la práctica de recoger lo que ha quedado después de la celebración. Barbara Kirshenblatt-Gimblett escribe que "los artefactos etnográficos son objetos de etnografía [...] Los objetos devienen etnográficos en virtud de que los etnógrafos los definan, segmenten, separen y transporten" (248). Sólo separados de sus contextos, los objetos pueden devenir etnográficos; sólo en el intervalo entre su lugar de origen y su posición de exhibición, visual o escrita. Por eso, dice la autora, debemos hablar de un fragmento etnográfico, que "se basa en una poética de la separación" y remite no sólo a un acto físico, "sino también a la actitud de separación como distanciamiento que posibilita dicha fragmentación y su apreciación” (249). La fotografía, dirá por su parte Roland Barthes, proporciona "una colección de objetos parciales" (62). La etnografía rescata esas parcialidades, "cosas comunes [que] están destinadas al olvido [...] demasiado triviales en su propia época para retirarlas de circulación y guardarlas para la posteridad" (Kirshenblatt-Gimblett 253-254). Trivialidad fragmentaria de los objetos, locuacidad de los gestos etnográficos que reúnen apartando.

La práctica etnográfica recolecta trozos para imaginar totalidades, pero Teatro Línea de Sombra sólo mostrará fragmentos como si su perspectiva se formara en la cerradura de una puerta a la que nos asomamos para ver algo que nunca alcanzaremos a percibir en su totalidad. Un teatro que elude la síntesis, en palabras de Lehmann, y que privilegia una percepción "abierta y fragmentaria" (144), creando de este modo, una "estructura onírica" en la que no existe "una jerarquía entre imágenes, movimientos y palabras", sino "una textura que se asemeja al collage, al montaje y al fragmento" (146).

La poética de la separación que Kirshenblatt-Gimblett atribuye a la etnografía sería correlativa, en este caso, a una de las parcialidades o las miradas oblicuas que nos prometen una visión completa, pero sólo ofrecen sesgos y perspectivas distorsionadas. El teatro como cámara oscura ${ }^{12}$ de los modos de representación y las coordenadas de

por un fervor de archivo más intenso y radical que el de Teatro Línea de Sombra, un fervor tan agudo que le permite olvidar la pieza para producir un archivo encarnado, que finalmente se disuelve en el recinto mismo donde se montó la obra. El fin del archivo, pero también su inicio, coincide con la disolución de la pieza, y también con su principio. Paradoja temporal de los archivos.

12 "Cuando la luz pasa a través de un pequeño agujero a un interior cerrado y oscuro, en la pared opuesta a la oquedad aparece una imagen invertida" (Crary 50). La cámara oscura, sostiene Jonathan Crary, no fue sólo un aparato o un conjunto de premisas técnicas, sino que estuvo inscrita "en una ordenación más amplia y densa del conocimiento y del sujeto observador" (51). Debemos pensar dos imágenes que 
la realidad; la etnografía como excavación diurna en las capas de una cultura y sus materialidades. Quisiéramos destacar que ambas disciplinas han tomado cosas y las han transportado, que sus poéticas parecen iniciar, al menos en el caso que estudiamos, en un gesto de apropiación de los objetos (y no sólo de ellos) que pertenecen al otro o que forman parte de sus mundos. La fragmentación es antecedida por la sustracción. El archivo no puede pensarse sin considerar estas dos prácticas. Y esto añade otra dimensión a la sombra: cualquier objeto apropiado y desplazado - no sólo las fotografías que nos importan-, deja una sombra en el lugar donde fue tomado, sombra de una sustracción y de los movimientos que suscita. Entonces, podríamos observar a través de este archivo las sombras que habitan los espacios donde estuvo. Tal vez aquí estamos ante una noción mortuoria de sombra, como ese objeto que en un velorio reemplaza al ataúd y en torno al cual se realizan algunos ritos (De la Garza, Sueño y éxtasis). El archivo de sombras se localizaría en ese lugar de apropiación y sustracción, para recordar la disposición inicial de los objetos que acumula y registra.

\section{Un segundo de angustia y otro de júbilo}

\section{La escena está aún elevada, pero ya no emerge de una hondura \\ Walter Benjamin}

En un texto que cita Georges Didi-Huberman, Pierre Fedida narra la historia de dos niñas que habían perdido a su madre recientemente y elaboraban el duelo jugando con una sábana que extendían sobre sus cuerpos como una mortaja. La presencia del cuerpo y la ausencia del cadáver se intercalaban entre risas y gritos, entre el dolor de la pérdida y la alegría del juego. Era una tela que servía de membrana y umbral, de cubierta y máscara, como si la muerte y la vida pudieran separarse mediante la sutil presencia de un límite y el cadáver se distinguiera del cuerpo vivo a través de una intervención objetual que cubre

\footnotetext{
hemos propuesto para describir el teatro de Línea de Sombra: el ojo de una cerradura y la cámara oscura. La posición del observador en ellas es disímil: en una, mira de frente a través de una abertura restringida a la amplitud de un lugar (una estancia, por ejemplo); en la otra, observa la amplitud invertida de una imagen proyectada a través de un orificio estrecho. Tal vez debemos pensar en una posición para el espectador de las piezas (la cerradura) y otra para sus creadores (la cámara oscura). Es decir, veríamos la imagen invertida proyectada en la cámara oscura (la pieza) como si miráramos algo a través de una cerradura (la escena).
} 
INVESTIGACIÓNTEATRAL

Vol. 10, Núm. 15

abril-septiembre 2019
Un archivo de sombras

Rodrigo Parrini, Daniel González

Marín, Alfadir Luna

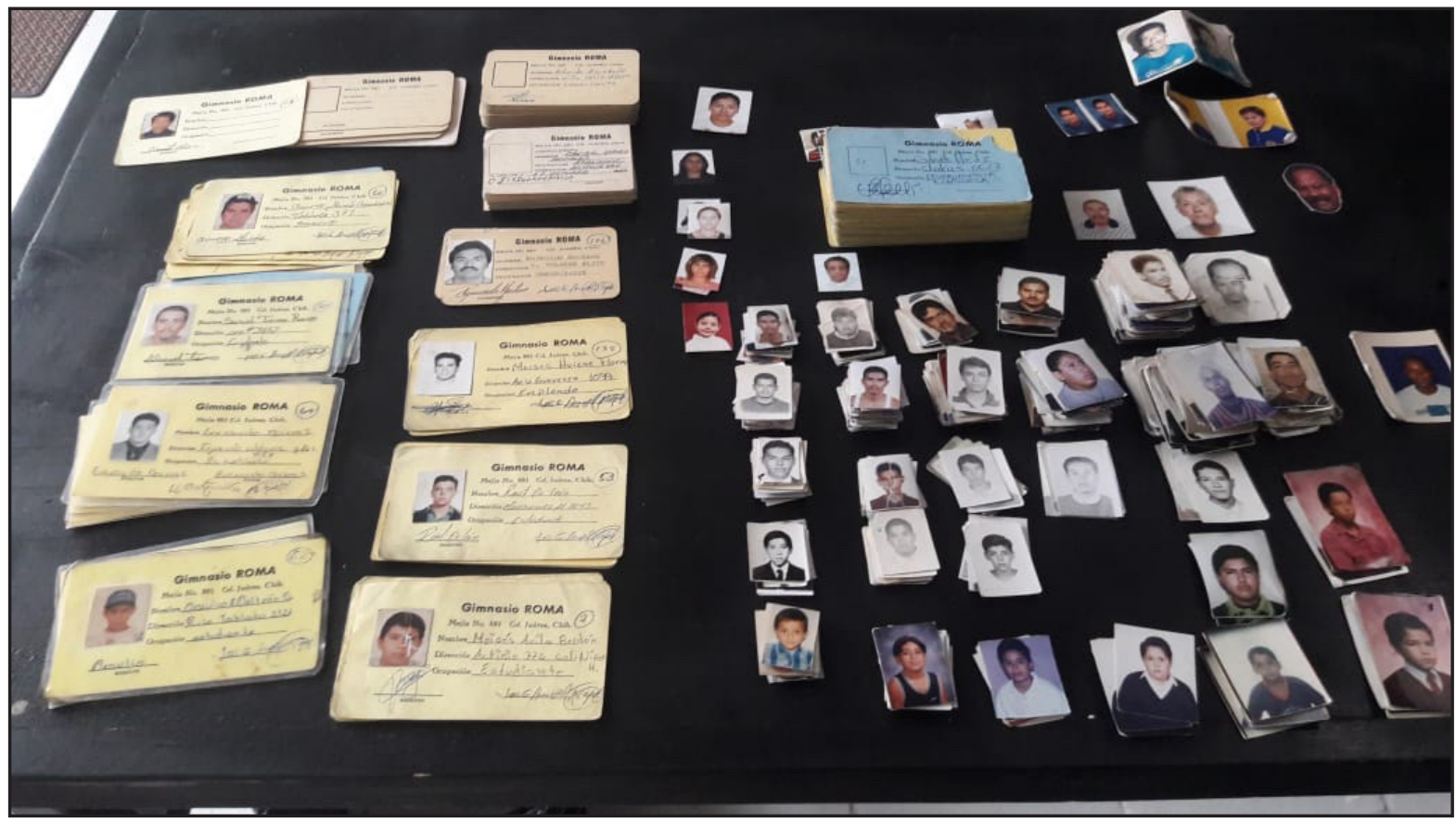

Fotos y credenciales. Archivo Teatro Línea de Sombra. Fotografía de Alfadir Luna.

y descubre. Pero esa sábana inauguraba una distinción entre un campo de preguntas y otro de respuestas: cuando la mayor de las hermanas se tapa, la menor grita y llora, y al quitarse la sábana, ríe. Ante el cuerpo cubierto/amortajado, la pequeña se pregunta si su hermana está muerta (y llora) y al levantar la sábana sabe que no lo está (y se alegra). La interrogación se formula en ese instante cuando corremos el velo para conocer un cuerpo. Un segundo de angustia y otro de júbilo.

¿La imagen retrata al sujeto o constituye un velo que le da forma, pero también lo extravía? ¿Son las fotografías y las credenciales del archivo que nos interesa, como sábanas o mortajas que cubren/descubren, que trazan un contorno e inauguran una pregunta? ¿Será el archivo mismo semejante a ese movimiento de cubrir/descubrir, en el que atravesamos el abismo entre estar vivos o muertos y en el cual nos podemos preguntar sobre esos rostros y esas vidas? Cuando TLS muestra esas imágenes a través de otras proyectadas en una pantalla: ¿cubre los rostros o los exhibe?, ¿muestra los cuerpos o los esconde?, ¿podemos imaginar ese gesto a partir del juego de la sábana, expuesto por Fedida y Didi-Huberman? Si así fuera: ¿sería la pieza un modo de elaborar otros duelos, esta vez no identificables, generalizados quizás, duelos colectivos que también se juegan en las imágenes, pero que adquieren densidad en la historia? 
Si el archivo fuera una sábana que no podemos levantar, pero con la que cubrimos otras imágenes, ¿qué preguntas se esgrimirían en ese momento agónico en el que interrogamos la vida y preguntamos por la muerte? "Todo cuerpo sumergido en la sombra, en una sombra de la que no sale, es un cuerpo invisible", escribe Didi-Huberman, "pongámoslo a la luz y se hará visible, sin duda, pero no por ello dejará de proyectar una sombra en algún lugar: su sombra, su parte de misterio" (Didi-Huberman, "El gesto fantasma" 281). Si el archivo fuera esa sábana que traza el umbral del duelo, pero que también territorializa la fiesta (la resurrección ficcional de una muerte aparente), los cuerpos nunca se vuelven visibles y siempre permanecen velados. Es con esas sombras de visibilidades pospuestas con las que TLS elabora Baños Roma. Si todo cuerpo sumergido en la sombra es invisible, cualquier cuerpo tapado por estas sábanas archivísticas y escénicas es un cuerpo velado. No se trata de correr los velos, sino de agitarlos y superponerlos. Y en ese sentido, el anonimato mismo, esa pregunta-velo que cubre los rostros de las fotografías y mece las vicisitudes de la historia social de un colectivo o de una ciudad, es otra sábana que resguarda el misterio al que se refiere Didi-Huberman; la sombra, dice ese autor, "es un fantasma, un miedo visual que emana de los cuerpos, los pone en peligro o nos pone en peligro a quienes los miramos" (ibídem). Las sábanas filtran la luz, por lo que no podríamos decir que un cuerpo cubierto por alguna yace en la oscuridad, pero nos expone a un peligro: saber si el cuerpo cubierto está vivo o muerto. El dilema que se traspone a las imágenes del archivo.

En un texto que dedica a Roland Barthes, Jacques Derrida escribe:

en un mundo que deshace los cuerpos vaciando la imagen de su poder genealógico [...], se pierde la ausencia. [...] Si todavía queda alguna posibilidad de tocar el dolor humano, será a través de las formas fantasmales de los aparecidos de un duelo inconsolable (9).

La sábana es también un límite para el tacto de los cuerpos, que podemos palpar mediante esa superficie que se interpone entre las pieles o entre las miradas. Restituimos así la ausencia, pero para discutir su estatus definitivo; como nos preguntamos sobre las vidas de las imágenes del archivo para reconocer, aún en la falta de respuesta, la posibilidad de un saber venidero. Tocamos, siguiendo a Derrida, el dolor humano, pero no sólo en el duelo inconsolable que menciona, también en una fiesta que surge y se desliza en distintos espacios y sentidos. La consolación imposible se vincula con una celebración infinita. Sólo en esta medida, o dada esta posibilidad, tiene sentido este archivo como parte de una pieza teatral: como argumento para la fiesta y como motivo para un duelo. Si esas fotos esgrimieran un duelo inconsolable, entonces la ausencia sería definitiva. Pero las preguntas que podemos plantear, las dudas que cruzan la escena y las prácticas teatrales, esa fragilidad material de las fotografías y las credenciales, rodean la ausencia de afectos, 
de intensidades estéticas y corporales; cuidan de ella extendiendo una sábana/archivo que cubre y vela, tapa y protege, aparta y vincula. Para el teatro, el poder de un archivo reside en la posibilidad de crear umbrales en los que una escena o una pieza completa se detengan, bordes para imágenes solapadas o perpendiculares, esbozos de otros mundos para miradas dolidas o celebratorias.

El archivo, en este caso, impide que Línea de Sombra elija el duelo o la fiesta y deba desplegar una práctica artística de duelo y celebración. Baños Roma puede leerse, en este modo, como el movimiento -al que apuntaba Jankélévitch- de entrar y salir de un umbral, estar dentro y fuera de modo indistinto.

El teatro, escribe Thayer, "habla de un desdoblamiento voyeurista" en que el rito se transforma en un espectáculo, "dando origen a la diferencia escena/platea, a la representación del acontecimiento, al acontecimiento como representación” (83). En ese desdoblamiento, el foso -afirma este autor- "señalaba estructuralmente la autonomía de la puesta en escena, de los actores y de las luces", y la oscuridad de la platea, su silencio (ibídem). En la lectura de Thayer, el foso se torna pantalla o muralla, frágil según Freud, "fragmentaria y discontinua [...] como una rica rompiente de cargas y contracargas, una pasarela de travestimientos, disfraces, eufemismos y velamientos" (84). La destrucción del teatro, que Benjamin identifica en el tránsito de un modo de producción auréatico-teatral a otro cinematográfico-industrial, se localizaría en el foso mismo, "que posibilita la tópica teatral escena/platea y las jerarquías y transferencias, la economía y la dinámica de sus partes" (169). Después de dicha destrucción, el foso ha desaparecido (también la escena, la platea, los autores) y "se ha hecho visible el teatro" (171).

Volvamos a imaginar el archivo como una sábana que traza un umbral frágil, pero intenso, entre la vida y la imagen, entre la muerte y la memoria, entre los rostros y los nombres. Imaginemos un teatro que se ha hecho visible mediante ese sudario/manto y que ha interpuesto una sábana, "fragmentaria y discontinua", entre la escena y su público (y no un foso). Desde una perspectiva etnográfica, el archivo existe antes y después de la pieza y lo recopilamos e interpretamos como un lugar distinto a la obra, aunque vinculado con ella. Entonces, la práctica etnográfica levanta las sábanas/umbrales para conocer qué hay (o había) debajo de ellas; alza los sudarios para enterarse de la muerte. La etnografía, su vocación inmediata de conocimiento, su afán de recolección pausada y sistemática, no se detiene en ese umbral/límite, en ese friso que separa al cuerpo muerto simulado, del vivo suspendido -como en el juego de las niñas en duelo-. Pero para el teatro, el archivo no está fuera de la escena, sino dentro de ella, y el umbral no se descubre ni se atraviesa, sino que se sostiene y desde ahí "se hace visible el teatro".

Si fuera correcta la lectura que Thayer hace de Benjamin y la destrucción del teatro correspondiera con la desaparición del foso: ¿qué otros contornos marcan al teatro?, ¿qué 
orillas se trazan en una escena?, ¿qué exterioridades la rodean? Si la escena aún está elevada, pero ya no surge de la hondura -como anota Benjamin-, ¿qué le provee esa altura?, ¿qué otras honduras podemos imaginar que no sean las del foso? En el juego, la sábana que cubría los cadáveres simulados producía una hondura singular: la del cuerpo muerto, la del velo mortuorio, la del sudario extendido sobre el cadáver. A pesar de la ligereza de la tela, la separación que generaba era honda y eso conmovía a las niñas. La hondura surge de la radicalidad de la separación y eso podría leerse como otro tipo de foso, como la distancia insalvable entre la vida y la muerte o entre un cuerpo vivo y el cadáver. El duelo se juega en esas honduras, en esos fosos emocionales y ontológicos. Pero también la fiesta.

El archivo de sombras puede leerse como una sábana extendida sobre la escena en tanto registre y produzca esos umbrales y los conduzca a lugares insospechados, los habilite en otros espacios y de otras maneras. Ese archivo de fotografías, que puede leerse como una enorme mortaja visual que cubre esos rostros exhibiéndolos, constituiría un borde flotante que pende sobre la escena como un velo o que la rodea como un foso. Separa al teatro del mundo, pero mediante un gesto radical de infiltrar al mundo en el teatro -esas vidas anónimas, esos rostros no identificables.

Baños Roma es la solución trémula a las preguntas-fantasmas y a las preguntas-velos que inquietan a sus creadores.

El archivo de sombras es un archivo de miradas: las que surgen de los retratos reunidos y las de quienes los observan ocasionalmente. Dadas las preguntas que rondan sus vidas y sus imágenes, parece que esos sujetos nunca dejarán de ser observados, pero, por otra parte, nunca perderán "la capacidad de hacernos frente y mirarnos", como sostiene Didi-Huberman (Pueblos expuestos 75). Esos rostros son singulares, justamente porque son anónimos, como si no necesitaran un nombre para poder mirarlos o conocerlos. Un nombre que individualiza, pero también cerca. Un rostro desconocido sobre el que podemos imaginar muchas vidas. Esas imágenes no hablan de un sujeto, sino de existencias que se hacen visibles ante nuestros ojos, así como se apaga la vida del boxeador. El teatro se dirime en esa tensión entre rostros sin nombre que inauguran un misterio, frente a esa existencia nombrada o nombrable ("Mantequilla" Nápoles) que anuncia un destino.

¿No es el anonimato un modo en el que el archivo nos interroga? La ausencia de un nombre no es un problema de la fotografía, porque ahí están los rostros sin necesidad, parece, de ser llamados. La imagen invoca. El nombre como problema surge cuando interrogamos algo más que a esos rostros. Y en esa tensión inicia el tráfico de fotografías que hemos pensado en este texto, un tráfico en direcciones múltiples, de materiales diversos, con sentidos distintos. Tráfico de honduras y superficies lisas, de fosos y sábanas. El archivo es el sedimento de ese tráfico constante, su huella. 


\section{Fuentes consultadas}

Agamben, Giorgio. Profanaciones. Traducido por Flavia Costa y Edgardo Castro, Buenos Aires: Adriana Hidalgo, 2005.

Agamben, Giorgio. Signatura rerum. Sobre el método. Traducido por Flavia Costa y Mercedes Ruvituso, Barcelona: Anagrama, 2010.

Barthes, Roland. La cámara lúcida. Notas sobre la fotografía. Traducido por Joaquim Sala-Sanahuja, Barcelona: Paidós, 1989.

Batchen, Geoffrey. Arder en deseos. La concepción de la fotografía. Traducido por Antonio Fernández Lera, Barcelona: Gustavo Gili, 2004.

Cadava, Eduardo. Trazos de luz. Tesis sobre la fotografía de la historia. Traducido por Paula Cortés Rocca, Buenos Aires: Palinodia, 2014.

Celan, Paul. Obras completas. Traducido por José Luis Reina Palazón, Madrid: Trotta, 2001.

Crary, Jonathan. Las técnicas del observador. Visión y modernidad en el siglo XIX. Traducido por Fernando López, Murcia: Centro de Documentación y Estudios Avanzados de Arte Contemporáneo, 2008.

Derrida, Jacques. Las muertes de Roland Barthes. Traducido por Raymundo Mier, México: Taurus, 1999.

De la Garza, Mercedes. Sueño y éxtasis. Visión chamánica de los nahuas y los mayas. México: Universidad Nacional Autónoma de México/Fondo de Cultura Económica, 2012.

Didi-Huberman, George. "El gesto fantasma”. Acto: revista de pensamiento artístico contemporáneo, núm. 4, 2008, pp. 280-291.

Didi-Huberman, George. Ante el tiempo. Historia del arte y anacronismo de las imágenes. Traducido por Antonio Oviedo, Buenos Aires: Adriana Hidalgo, 2011.

Didi-Huberman, George. Pueblos expuestos, pueblos figurantes. Traducido por Horacio Pons, Buenos Aires: Manantial, 2014.

Didi-Huberman, George. Pueblos en lágrimas, pueblos en armas. El ojo de la historia, 6. Traducido por Mariel Manrique y Hernán Marturet, Santander: Shangrila, 2017.

Diéguez, Ileana. Cuerpos sin duelo. Iconografías y teatralidades del dolor. Monterrey: Universidad Autónoma de Nuevo León, 2016.

Foster, Hal. El retorno de lo real. La vanguardia a finales de siglo. Traducido por Alfredo Brotons Muñoz, Madrid: Akal, 2001.

Foster, Hal. 2004. "An Archival Impulse". October, vol. 110, 2004, pp. 3-22.

Frontera List. 2018. "Yearly Death Tolls in Ciudad Juárez". Frontera List: News and Discussion of US-Mexico Border Issues, www.fronteralist.org/tag/molly-molloy/, consultado el 18 de diciembre de 2018. 
Guasch, Ana María. Arte y archivo, 1920-2010. Genealogías, tipologías y discontinuidades. Madrid: Akal, 2015.

Jankélévitch, Vladimir. La aventura, lo serio, el aburrimiento. Traducido por Elena Benarroch, Madrid: Taurus, 1989.

Kirshenblatt-Gimblett, Barbara. "Objetos de etnografía". Estudios avanzados de performance, selección de Diana Taylor y Marcela Fuentes. Ciudad de México: Fondo de Cultura Económica, 2011, pp. 243-303.

Lehmann, Hans-Thies. Teatro posdramático. Traducido por Diana González, Ciudad de México: Cendeac/Paso de Gato, 2013.

Martínez, Oscar. Ciudad Juárez: El auge de una ciudad fronteriza a partir de 1848. Ciudad de México: Fondo de Cultura Económica, 1982.

Monárrez, Julia Estela. "La cultura del feminicidio en Ciudad Juárez, 1993-1999". Frontera norte, vol. 12, núm. 23, 2000, pp. 87-117.

Parrini, Rodrigo. "Canto de Palomas. Teatro de los animales y etnografía del espacio". Cartografías Críticas. Volumen II, compilado por Ileana Diéguez, editado por Paola Marín y Gastón Alzate. Los Ángeles: Ediciones Karpa, 2018, http://www.calstatela. edu/al/karpa/r-parrini, consultado el 18 de diciembre de 2018.

Rancière, Jacques. El tiempo de la igualdad. Diálogos sobre política y estética. Traducido por Javier Bassas Vila, Madrid: Herder, 2011.

Rufer, Mario. "El archivo: de la metáfora extractiva a la ruptura poscolonial". (In)disciplinar la investigación. Archivo, trabajo de campo y escritura, coordinado por Mario Rufer y Frida Gorbach. Ciudad de México: Siglo xxi/Universidad Autónoma Metropolitana, 2016, pp. 160-186.

Schino, Mirella. "Building the Archives of a Theatre Laboratory". Dramatica, núm. I, año LIX, 2014, pp. 415-424.

Spieker, Sven. The Big Archive. Art from Bureaucracy. Cambridge: Massachusetts Institute of Technology Press, 2008.

Stoichita, Victor I. Breve historia de la sombra. Traducido por Anna María Cordech, Madrid: Siruela, 1999.

Thayer, Willy. Tecnologías de la crítica. Entre Walter Benjamin y Gilles Deleuze. Santiago: Metales Pesados, 2010.

Teatro Línea de Sombra. "Baños Roma". TLS. Teatro Linea de Sombra, www.teatrolineadesombra.com/banosroma.html, consultado el 18 de diciembre de 2018.

Vázquez, Juan Manuel. "Una vez me puse los guantes con Alain Delon". La Jornada, 25 de julio de 2009.

Weizman, Eyal. The Least of All Possible Evils. Humanitarian Violence from Arendt to Gaza. Londres y Nueva York: Verso, 2011. 


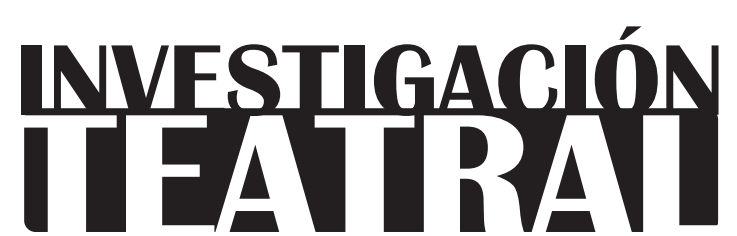

Revista de artes escénicas y performatividad

Vol. 10, Núm. 15

abril-septiembre 2019

Segunda época

ISSN impreso: 1665-8728

ISSN electrónico: 2594-0953

Universidad Veracruzana

\title{
El diálogo afectivo con la tradición en el teatro chileno reciente: una lectura de Neva, de Guillermo Calderón
}

\author{
Javiera Larraín George*
}

\footnotetext{
* Pontificia Universidad Católica de Chile, Chile. e-mail: javiera.larraing@gmail.com
}

Recibido: 26 de noviembre de 2018

Aceptado: 27 de febrero de 2019 


\title{
El diálogo afectivo con la tradición en el teatro chileno reciente: una lectura de Neva, de Guillermo Calderón
}

\section{Resumen:}

El presente artículo pretende establecer una lectura acuciosa de la obra Neva, del destacado dramaturgo y director Guillermo Calderón, a través de su trabajo en torno a la metateatralidad y el uso de la voz natural. Neva, en consecuencia, articula los principios básicos de aquellos elementos que son característicos de gran parte de la producción del autor. Asimismo, a partir del análisis de esta obra se persigue entender la filiación entre el trabajo de Calderón y la tradición chilena teatral que éste hereda, influida por una fuerte presencia del realismo naturalista.

Palabras clave: Guillermo Calderón, teatro chileno, metateatralidad, realismo, voz, Chile.

\section{An Affective Dialogue with Tradition in Recent Chilean Theater: A Reading of Neva, by Guillermo Calderón}

\begin{abstract}
:
This article seeks to establish a thorough reading of Neva, by prominent Chilean playwright and director Guilermo Calderón, using both his work on metatheatricality and the natural voice. The reading will therefore articulate the basic principles of the elements that characterize the author's entire production. From the analysis of this piece, we seek to understand the relationship between Calderon's work and the Chilean theatrical tradition that he inherits, influenced as it is by a strong presence of naturalist realism.
\end{abstract}

Keywords: Guillermo Calderón, chilean theater, metatheatricality, realism, voice, Chile. 


\section{El diálogo afectivo con la tradición en el teatro chileno reciente: una lectura de Neva, de Guillermo Calderón}

El trabajo cobró así su ritmo, con excepción del papel de Masha, que habia tocado a la actriz Knipper. De esto se ocupó Vladimir Ivánovich, y pronto también a ella se le reveló algo en el alma, y todo comenzó a marchar de las mil maravillas.

El pobre Antón Pávlovich no pudo esperar hasta la representación. Tuvo que irse al extranjero, bajo el pretexto de que su salud había empeorado; aunque yo sospecho que hubo otra causa más: la preocupación por la pieza y su destino ulterior en las tablas. Esta suposición se vería confirmada por la circunstancia de que ni siquiera nos dejaba la dirección adonde podríamos dirigirnos para informarle sobre los resultados del estreno. Ni siquiera la misma Knipper la conocía, a pesar de que ella...

Konstantín Stanislavski, Mi vida en el arte (1925)

\section{Breve panorama sobre la escena chilena del nuevo milenio} a primera década del siglo Xxi se caracteriza por un reajuste en los modelos teatrales de la escena nacional en Chile. Los directores de esta nueva generación, ${ }^{1}$ junto con sus compañías, ya no buscan, primordialmente, "montar" textos, sino que realizan

1 Para las pretensiones del presente artículo, los autores circunscritos en la generación de Guillermo Calderón se inscriben -según la propuesta de Cedomil Goic- en la generación del 2002, ya que éstos nacie- 
un trabajo de investigación escénica que surge desde la praxis y las inquietudes direccionales y actorales del grupo de trabajo a partir de los propios procesos de ensayos. En palabras de María de la Luz Hurtado, esta generación destaca por sus "Desplazamiento[s] e hibridaciones, entonces, contaminaciones mutuas entre arte y cultura en las cuales los academicismos son transgredidos como programa base. La 'pieza bien hecha', el 'montaje bien realizado' como interpretación fiel a una supuesta voluntad autoral originaria se bate en retirada en el teatro" (Teatro chileno 18). Los directores teatrales de la escena chilena del nuevo milenio ${ }^{2}$ ponen en juego una serie de lenguajes eclécticos, logrando hacer dialogar el discurso de la tradición con aportes nuevos, acordes a las recientes tecnologías que aportan los formatos audiovisuales, sonoros, lumínicos, entre otros.

La figura de Guillermo Calderón $(1971)^{3}$ conforma, precisamente, parte de este eje generacional; comienza su trabajo con la Compañía Teatro en Blanco, para después continuar

ron entre 1965 y 1979. Si bien la propuesta de fechas fronterizas de Goic puede ser puesta en jaque en relación a sus supuestos positivistas y a su centralización en una generación de dramaturgos y no necesariamente de directores, su ordenamiento temporal es útil en el sentido que da cuenta de la orfandad crítica de los teatristas surgidos en las últimas tres décadas. Para Goic, habría cinco generaciones de autores teatrales chilenos en los últimos cien años: 1927 (superrealistas), 1942 (neorrealistas), 1957 (irrealista), 1972 (novísimos), además de 1987 y 2002. Hasta la fecha, no existen estudios que, por una parte, puedan dar cuenta de manera sintomática de los rasgos distintivos de estos dos últimos grupos y que, por otra parte, problematicen las redes rizomáticas de entramados relacionales entre las generaciones de 1987, de 2002 y aquella que actualmente le seguiría -correspondiente a autores nacidos a partir de 1980-. Ambos aspectos quedan excluidos de las pretensiones del estudio de Goic, siendo que son problemáticas sumamente necesarias al momento de abordar las prácticas teatrales locales actuales en su total dimensión (Historia y crítica de la literatura hispanoamericana 535-538).

Dentro de esta camada de noveles directores destaca el hecho que muchos de ellos circunscriben sus primeros pasos alrededor de una compañía específica - en algunos casos disueltas en la actualidad- con la que comienzan a formar su propia metodología de trabajo; tal es el caso de figuras como: Ana Harcha Cortés (1976) y Francisca Bernardi (1975), quienes fundan la Compañía Niños Prodigio; Alexis Moreno (1978) y Alexandra Von Hummel (1975), que conforman el Teatro La María (1996); Manuela Infante (1980), fundadora de Teatro de Chile; Luis Ureta (1967), con Teatro La Puerta (1991), y Martín Erazo (1973), con la Compañía La Patogallina (1996), sólo por nombrar algunos casos de compañías teatrales chilenas de los últimos 15 años y que, hasta el día de hoy, algunas de ellas, como sus directores, se encuentran activos en un constante aporte de nuevas obras a la escena nacional. En el marco de este panorama, cabe rescatar que, si bien todos estos directores conforman parte de una misma generación, que según Cristián Opazo, reconocen un teatro nacional cuyo fundamento -o al menos parte de éste- se reconoce en la evanescencia de todo rasgo de realidad, de verdad, de ficción y de impostura (Clase, de Guillermo Calderón 17).

3 Nacido en Santiago, en 1971, su juventud se encuentra marcada por los últimos años de dictadura en Chile. Estudia Teatro en la Universidad de Chile (1989-1993); posteriormente, realiza estudios de especialización en el extranjero: primero, en el Actor's Studio, en Nueva York, E.U., que no continuó por no 
INVESTIGACIÓNTEATRAL

Revista de artes escénicas y performatividad

Vol. 10, Núm. 15

abril-septiembre 2019
El diálogo afectivo con la tradición

en el teatro chileno reciente

Javiera Larraín George

con la Compañía La Reina de Conchalí y otros colectivos. Él forma parte de esta nueva generación de directores que "va constituyendo autorías con personalidad propia no necesariamente mimetizadas con los modelos del centro" (Hurtado, Prólogo 18). Las propuestas de dirección de Calderón ${ }^{4}$ y de su generación descansan, en parte, en la polémica existente entre cuerpo, texto y representación, en donde los ejes de realidad parecerían estar constantemente en jaque desde el constructo de lo (meta)teatral, poniendo, así, "en evidencia la cualidad dual de lo teatral y de la escena, reflexionando de este modo a la par sobre la relación entre realidad y representación, núcleo de lo teatral (y de la vida en tanto lugar de la performance)" (44).

Las preocupaciones autorales ahora, en consecuencia, son otras. Si bien, durante los años 80 y 90, la dirección de la escena chilena buscaba establecer un nuevo estado de sí misma tras la dictadura, a principios del año 2000 las prácticas escénicas parecieron volcarse hacia una búsqueda por el entendimiento de su propia teatralidad. Las prácticas teatrales de comienzos de 2000 se configuraron desde una repolitización de la escena, heredera de las prácticas transformadoras de mediados de los años $80 .^{5}$ En términos de Villegas:

El teatro político no ha desaparecido, aunque sí ha cambiado el mensaje y el modo de comunicación del mismo [...] La diferencia clave con el período anterior radica en

sentirse tan a gusto con las lógicas de actuación stanislavskianas, lo cual lo lleva a profundizar, en segunda instancia, en el teatro físico en la Scuola Dell'Arte en California, E.U., y en la Scuola Internazionale dell'Attore Comico, en Italia. Además, cursó un Máster en Artes Liberales con mención en Cine en la City University of New York, E.U.

4 Permítaseme una precisión metodológica: el presente artículo no busca instalar un análisis de la obra total de Calderón, sino más bien problematizar los ejes fundamentales de la primera parte de su poética, la cual está constituida -desde mi perspectiva crítica- por la tríada compuesta por Neva (2006), Diciembre (2008) y Clase (2008). En todos estos montajes, Calderón articula una relectura -según indican Oyarzún y Opazo- de la tradición clásica del drama moderno (21). Es así que, a través de este gesto, busca cuestionar el teatro en contextos de crisis (revolución civil, guerras y marchas estudiantiles). Para ello, se atiene a un uso minimalista de los recursos materiales del espacio escenográfico, para poner el acento en el trabajo actoral. Lo anterior se diferencia de sus siguientes trabajos (Villa + Discurso, 2010; Escuela, 2013, y Mateluna, 2016) que tienen un foco más centrado en la exposición de un teatro de corte documental -incluso, a ratos, testimonial-; y que buscan alejarse de una lógica de actuación teatral por parte de los actores, transitando hacia un estilo interpretativo más cinematográfico (Larraín, Hacia una poética 228-232).

Directores como Andrés Pérez, Ramón Griffero, Alfredo Castro, Rodrigo Pérez y grupos como La Troppa o Teatro del Silencio transformarán el panorama de la escena chilena a partir de la segunda mitad de la década de los años 80. A partir de ellos se establecerán distintas filiaciones y herencias con las generaciones venideras. 
que el mensaje no suele ser tan directo y los códigos teatrales empleados enfatizan una mayor complejidad estructural y participación del espectador en la decodificación del mensaje. El discurso teatral en esta época incorpora la parodia, la ironía, la metateatralidad como recursos recurrentes que contribuyen, con frecuencia, a la ambigüedad del mensaje (216).

Dicha ambigüedad no se enmarca en la falta de toma de partido y perspectiva ideológica por parte de los autores de la escena teatral posmoderna, sino, más bien, en la necesidad de instalar un panorama político que se encuentra dominado por el escepticismo, con el fin de atestiguar, al mismo tiempo, una voluntad de reminiscencia. Para Avelar, esta voluntad atestigua un llamado de atención del presente a todo aquello que no se logró en el pasado y permea una mirada escéptica del propio presente, al ser producto de una catástrofe del pasado (286).

En este contexto, atravesado por una desconfianza hacia los proyectos político-democráticos, Calderón configura una neo-irrupción de lo real, sin olvidar las alteridades friccionales entre lo real y la ficción, ejes centrales de estas nuevas propuestas escénicas, puesto que el gran aporte del autor consiste en retomar un código tradicional y clásico -el realista- para hacerlo irrumpir en la escena chilena actual, resignificándolo y dotándolo de un nuevo sentido desde el punto de vista:

de la generación de autores y directores teatrales en la que Calderón se inscribe con una voz muy propia, lo vanguardista sería hoy en día montar en Chile obras de Brecht, por ejemplo, intervenidas por la opinión de quienes las escriben y/o dirigen. Es curioso que un clásico del teatro mundial pueda operar como elemento transgresor en un momento puntual (Lagos, Neva: El río 17).

De ahí que pueda entenderse su neo-irrupción de lo real como un acto de vanguardia y subversión escénica. Calderón homenajea la tradición en sus primeros montajes, pero no desde un lugar condescendiente, sino críticamente interpelativo en su exploración de las paradojas - muchas de ellas absurdas - entre el teatro y la vida. Así, para Hurtado, "pareciera que las utopías no han caído definitivamente en el teatro chileno, y que el relativismo postmodernista sea su única y desencantada visión de mundo" (Prólogo 47).

En este panorama de producción se enmarca el trabajo ${ }^{6}$ de Guillermo Calderón. La crítica chilena e internacional han señalado, casi por unanimidad, que es uno de los autores más

6 La obra de Guillermo Calderón es vasta y prolífica, ya no sólo en Chile, sino en todo el mundo. Ha sido invitado para escribir y dirigir en prestigiosos teatros dentro del mundo: Düsseldorfer Schauspielhaus, Theater Basel, HAU Hebbel am Ufer, el Royal Court Theatre, Center Theatre Group, y el Public Theatre en 
importantes de las últimas décadas dentro de la escena nacional chilena (Labra, Ibacache, Bahamondes, Letelier, Oyarzún y Lagos) y la prensa internacional ha alabado sus puestas en escena en el extranjero (The Guardian, The New Yorker, The Washington Post, El Pais, Clarín). De la misma forma, en el mundo académico es posible encontrar no poco -aunque tampoco bastante- material de estudio sobre el autor, sobre todo artículos y tesis de pregrado y posgrado en alguna de sus obras. La mayoría de estas revisiones -sean prensa, crítica especializada o estudios académicos - destacan el papel predominante de la palabra dentro de la construcción de sus piezas que, según Juan Andrés Piña, en Calderón "la envolvente o incluso apabullante marea verbal alcanza por momentos una cima poética; en otros casos primará la fuerza ideológica de quien expone un argumento, su capacidad de representación de un desgarro íntimo, el soliloquio de alguien extraviado en el dolor y la soledad o, también, el relato de una historia que un personaje narra a los demás" (170-171). Por su parte, Carola Oyarzún enfatiza que "Calderón se instala en nuestro campo teatral como una de las figuras más destacadas. Su dedicada relectura de textos clásicos, sumada a su constante preocupación por las coyunturas históricas pasadas (guerras, revoluciones y revueltas callejeras) y presentes hablan, sin duda, de una dramaturgia/dirección que cuestiona el sentido del teatro en contextos dominados por la crisis" (305). Mientras que María de la Luz Hurtado señala que lo metateatral cruza su obra y "se constituye en la indagación en torno a las claves [...] de la memoria emotiva y física de los actores: de su vida personal, de lo vivido, sentido, observado, experimentado en carne propia, como fuente y correlato de la construcción de un personaje 'real', 'creíble,' 'vivo', afectiva, social e históricamente fundado" (Teatro chileno 45).

\section{Los albores de una poética al clamor de la revolución bolchevique}

Neva no es sólo el nombre de uno de los ríos más importantes de Rusia, que atraviesa la ciudad de San Petersburgo. También es el nombre de la primera obra escrita y dirigida por Guillermo Calderón, quien la estrenó en 2006, junto a la Compañía Teatro en el Blanco. La

la ciudad de Nueva York, donde también dirigió Neva con actores norteamericanos (The Public, Nueva York, 2012), al igual que Villa (Play Co, Nueva York, 2017). Las obras de Calderón han recorrido extensamente el mundo, destacando: Uruguay, Brasil, Bolivia, Canadá, Portugal, México, Cuba, Colombia, Escocia, Grecia, Estados Unidos, Francia, Italia, Inglaterra y, por supuesto, Chile. Participando, asimismo, en importantes festivales: Festival Internacional de Teatro de Buenos Aires (FIBA), Festival Fringe de Edimburgo, Festival de Artes Escénicas de Seúl, Festival Chekhov en Moscú, Festival de Teatro Iberoamericano en España, TeatroStageFest, Festival de Teatro de Viena, Festival Mundial de Teatro en Bruselas, Festival Bajo el Radar del Teatro Público, entre otros. 
anécdota se sitúa en 1905, en el preludio de la Revolución Rusa, en donde dos actrices y un actor -Olga Knipper, viuda del dramaturgo Antón Chejov; Masha, una actriz de filiaciones obrero-proletarias, y Aleko, que se identifica con la noción burguesa pastoril tolstiana ${ }^{7}$ matan el tiempo, mientras aguardan que sus demás compañeros lleguen a ensayar. En un claro guiño al teatro chejoviano, los tres personajes esperan. Para ello, citan y actúan diversos fragmentos de escenas de las obras del autor, como El jardin de los cerezos, La gaviota e Ivanov; además, discuten sobre la situación político-social que acontece, por ese entonces, en el país. A petición de la propia Olga Knipper recrean las distintas versiones de la muerte de Chéjov. ${ }^{8}$

El montaje se articula, principalmente, en torno a la problematización de la acción, por medio del discurso verbal, en permanente tensión con el espacio interno y externo -el teatro y la revolución-, así como con su artificiosidad, es decir, con la representación en sí misma. Calderón pragmatiza cada secuencia de la obra desde una reflexividad escénica, en el ejercicio de revelar su propia construcción artificiosa al poner de manifiesto los compo-

7 A lo largo de toda la obra, Aleko pregona una visión de mundo cercana al georgismo -o georgism en inglés-, que fue respaldada por el escritor ruso León Tolstói hacia el final de su vida. De hecho, escribió el "Prefacio" para el libro de George, Social Problems, en donde ambos coincidieron tanto en el rechazo de la propiedad privada de la tierra, como también en la economía socialista de planificación centralizada. Muchos artistas e intelectuales de todo el mundo hicieron eco de esta "visión filosófica pastoril" de Tolstói, en que recomendaba austeridad en la comida y la bebida, la práctica de ejercicios de meditación, la lectura de salmos y pasajes bíblicos, el cultivo sustentable de la tierra y la vida retirada en el campo, entre otras cosas. Es más, en Chile se fundó la Colonia Tolstoyana, de la mano de Augusto d'halmar, Julio Ortíz de Zárate y Fernando Santiván, este último autor de Memorias de un tolstayano (1955). Su propósito era retirarse a un lugar apartado - ubicado en San Bernardo, en un terreno cedido por Manuel Magallanes Moure- para trabajar la tierra, leer, estudiar y crear en la tranquilidad espiritual y física que un estilo con dicha calidad de vida permitía. Por ello, las constantes alusiones de Aleko a la vida retirada y tranquila en el campo están en fuerte conexión con estos preceptos tolstianos; evidentemente, Calderón está al tanto de los mismos.

8 La anécdota de recrear una y otra vez la muerte de Chéjov podría ser leída intertextualmente con el cuento "Tres rosas amarillas", del escritor norteamericano Raymond Carver, en donde se ficcionalizan los últimos años de vida de Chéjov que antecedieron a su muerte por tuberculosis la madrugada del 2 de julio de 1904. Un momento central del relato tiene lugar durante la madrugada de una noche de verano, cuando Olga Knipper manda llamar al doctor Schwörer, preocupada por la salud de su esposo. El doctor, ante la inminente nula esperanza de la sobrevivencia del escritor, llama al personal del servicio del hotel para que le traigan una botella de champaña a la habitación. Una vez que Olga y el doctor destapan la botella, Chéjov perece. La historia de Carver finaliza con Olga Knipper en la soledad de la habitación de su hotel, haciéndose cargo de la muerte de su esposo. Guillermo Calderón, en Neva, intenta revivir una y otra vez este pasaje. 
nentes teatrales que la constituyen; o sea, al desplegar cómo una escena se constituye en sí misma como teatro. En consecuencia:

Si en la tradición teatral realista, la verosimilitud definía la relación que el espectador establecía con la obra, en Neva esta verosimilitud no es más que un anzuelo, una forma de seducir al espectador mostrándole una obra aparentemente tradicional, pero que sin embargo esconde una construcción (lenguaje, decorado, tiempo, espacio, etc.) que no hacen más que remitir a sí mismos, a su funcionamiento dentro de un universo autónomo y limitado. Este engaño pretende involucrar al destinatario, incomodándolo y suscitando en él una reflexión intelectual con respecto a la manera en que se produce la ficción dramática, ejercicio que le permite vincular indirectamente cómo ciertos discursos y prácticas constituyen los soportes de identidad en su realidad (Campos 7-8).

En Neva, entonces, se articula una serie de estrategias que plantean deconstruir la tradición realista previamente establecida a través de diversos mecanismos y estrategias escénicas, como son: su estructura metateatral, por medio de una propuesta de corte minimalista; un trabajo de dirección actoral, en donde se propulsa "lo real" sobre la verosimilitud realista tradicional, y una propuesta de trabajo de naturalización vocal por parte de los actores que permite canalizar la intensidad emocional.

\section{La metateatralidad como estética del despojo}

Para Soledad Lagos, el trabajo de Calderón opera centrado en una estética del despojo escénico, "donde lo único que cuenta son los actores y sus cuerpos puestos en espacio" (Neva: El río 17). A partir de una escenografía minimalista, compuesta solamente por una pequeña tarima en donde se sitúan los actores, una vieja silla de estilo clásico y una estufa, Calderón construye una atmósfera intimista y personal de un espacio privado minúsculo, concreto y singular: el de un ensayo teatral. La iluminación en penumbras, que cuenta principalmente con la luz que proviene de la estufa situada de cara a los actores -en la parte frontal baja de la tarima-, produce una atmósfera de candidez y cobijo que se contrapone al enfrentamiento verbal en el uso de la palabra durante todo el montaje, ya sea entre los enfrentamientos binarios de Olga-Masha, Aleko-Masha u Olga-Aleko. Estas constantes pugnas verbales entre los tres actores están intercaladas por las distintas improvisaciones y juegos de roles que realizan a lo largo del montaje, ya sea para recrear la muerte de Chéjov o para traer a escena la situación política que se vive afuera del teatro, puesto que: "La Historia 
que no es parte de la ficcionalización, la que está en las calles, irrumpe por referencias de Masha, quien, en forma muy lúcida, transmite lo que, para ella, terminará siendo eso que en ese momento ocurre afuera de la sala de teatro" (15).

En Neva es posible apreciar -como ya se ha remarcado anteriormente- una reflexividad en torno a su propia constitución como obra teatral, por medio del uso de recursividades metateatrales. Calderón plantea, en varias escenas, la posibilidad de distintos juegos de rol e improvisaciones, que se suceden unos a otros. Entre ellos destaca, primeramente, la escenificación de la muerte de Chéjov, en donde Olga hace un doble rol, pues no sólo es actriz, sino también directora de la muerte de su propio esposo; ella selecciona quién lo interpretará e indica cómo, supuestamente, fue el fallecimiento de éste:

AlEKO: Olga, yo interpreto a Antón.

OLGA: Gracias, Aleko.

MASHA: Yo también puedo interpretar a Chéjov.

OlgA: ¿Sí? (A Masha) A ver, tose. (A Aleko) Tose, Aleko (Aleko tose). Tose, Masha (Masha tose). (A Aleko) Tú vas a interpretar a Antón [...] Tú vas interpretar al doctor Schwörer. El doctor Schwörer tiene a Antón muy cerca y le está diciendo unas palabras en alemán que yo no alcanzo a escuchar. MASHA: Olga, yo no sé hablar alemán.

OLGA: (A Aleko) Ella es actriz y no sabe hablar alemán... ¿Entonces, cómo piensas? Vas a hablar alemán, porque el doctor Schwörer era alemán. En ese momento, tú le dices "ich sterbe".

AleKo: (A Masha) Me muero.

OLGA: En ese momento, Masha, le vas a inyectar alcanfor y luego [...] Te vas a tomar la copa, me la vas a pasar a mí... Y luego él va a morir... Va a morir, Masha. Gracias. Los dos son personas maravillosas. (Toman sus posiciones) ¡Acción! (Aleko tose).

MASHA: Soy el doctor Schwörer.

OLGA: ¡Doctor!

MASHA: Ich brait und wis if kurt nais kris yaikenshipnen... (Habla en alemán inventado. Aleko se ríe). Olga, yo no puedo seguir actuando, Aleko se está riendo de mi trabajo.

OLGA: ¿Cómo se te ocurre parar la escena cuando la escena acaba de empezar? [...] Y después me miras con cara de sorpresa cuando te digo que no tienes alma. ¿Te parece que es tener alma parar una escena en la mitad, cuando ya empezó? (Calderón 14-16). 
También son importantes las rencillas entre la hermana de Chéjov y Olga Knipper:

ALEKO: ¿Alguna escena en particular?

OlgA: Algo de mi vida. ¿Podrías actuar lo que le pasó a Masha Chejova, la hermana de Antón, cuando supo que nos íbamos a casar?

AleKo: (Como Chéjov) Masha, hermana, me voy a casar.

MASHa: (Como Masha Chejova) No.

ALEKO: Pero vas a vivir con nosotros.

MASHA: No. ¿Para qué te vas a casar, si yo te lo doy todo? [...] (A Olga) Cerda, alemana vil, te las arreglaste para atrapar a mi hermano. Si te conviertes en la Natasha de Las Tres Hermanas, te voy a estrangular con mis propias manos [...].

OLGA: Deja de hacer tantas clases, Masha. ¿Por qué no te enamoras? (25-26).

O las vicisitudes del pueblo ruso en aquel entonces, que parecen mezclarse involuntariamente con las del propio teatro: ${ }^{9}$

OlgA: (A Masha) Te da risa, te da risa que yo no sepa quién es Gapón. Pero, entonces, ríete, pero ríete más fuerte, ríete fuerte; si te vas a reír de mí, ríete fuerte. Que todo San Petersburgo se entere de lo cretina y estúpida que es Olga Knipper, que no sabe quién es Gapón. (Llorando) Yo no tengo por qué saber quién es Gapón, ¿por qué tengo que saber quién es Gapón? ¡Yo vengo llegando de Moscú!

ALEKO: Olga, siéntese, siéntese. Olga, el padre Gapón es el sacerdote que organizó la marcha de los trabajadores hoy en la mañana [...]. Olga, hoy en la mañana los trabajadores le llevaron una carta al zar [...]. La carta pedía justicia, protección. Decía: "Nos sentimos empobrecidos, oprimidos, nos tratan con desprecio, el despotismo nos está sofocando" [...].

OLGA. ¿Dónde está el padre Gapón? [...] ¿Murió?

$9 \quad$ Es interesante rescatar cómo, en Neva, es posible apreciar un gran trabajo de investigación historiográfica por parte de Calderón. La anécdota del escape disfrazado del sacerdote Georgy Gapon -que aquí se citano dista mucho de la realidad. Yedin Tova en -Maxim Gorky: A Political Biography-comenta que, tras el "Domingo Sangriento" del 22 de enero de 1905, Gapon efectivamente se escondió en la casa de Gorky, y fue el socialista Pinhas Rutenberg quien lo disfrazó de un "hombre común y corriente", para poder sacarlo de la ciudad. En un truculento giro argumental, Gapon murió asesinado poco más de un año después, en su retorno a San Petersburgo, al ser traicionado por el propio Rutenberg ante la Policía Secreta. 
MASHA. No, Olga. No está muerto.

OLGA. ¿Y tú cómo sabes eso?

MASHA: Yo estuve con el padre Gapón antes de llegar a ensayo. En la casa de Gorki.

OLGA: ¿Tú estuviste en la casa de mi amigo Máximo Gorki?

MASHA: Gorki me llamó. Necesitaban una actriz que supiera de maquillaje. Tenían que sacar al padre Gapón de la ciudad. Yo lo pinté de mujer y le puse una peluca (32-34).

La propuesta directorial de la obra descansa, así, en llevar a escena el nivel discursivo a través de una estructura metateatral. Aunque, en repetidas ocasiones, la prensa y la crítica ${ }^{10}$ han llamado a Calderón como "autor de texto", su trabajo dista mucho del entendimiento de un teatro meramente de discurso. Para Tobin Nellhaus: "Los discursos, lejos de ser solamente lingüística, se construyen con los iconos, índices y símbolos; y son elaborados en forma de articulaciones analógicas, expresivas, y lógicas. Aunque sus agentes entiendan sus acciones y las circunstancias que los rodean, y que orientan o motivan sus acciones posteriores" (151). ${ }^{11} \mathrm{Si}$ bien, las prácticas discursivas primariamente envuelven significados, ideas, imágenes y valores, también encarnan interacciones sociológicas materiales. Los discursos en Neva implican interacciones entre individuos o grupos, por lo que, consecuentemente, requieren de una audiencia o de un otro que pueda descifrar las actividades físicas involucradas en ellos, como son la producción de sonidos, las marcas gestuales o las muletillas (ibídem). La propuesta metateatral que la obra plantea se configura, bajo esta lógica, no como una apuesta estética o una estrategia dramatúrgica, sino como una decisión de dirección que descansa en la preocupación de dotar de sentido y significado a la palabra desde su condición material; es decir, desde la acción de comunicar, dado que: "La comunicación es una práctica productiva. Puesto que la comunicación produce varios efectos, incluyendo los significados y las relaciones interpersonales o sociales, se pueden lograr cosas mediante la comunicación [...] todos los actos de habla y, la comunicación en general, son performativos" (ibídem). ${ }^{12}$

10 Carola Oyarzún remarca esta condición que le ha dado la crítica a Calderón, pero agrega que su fuente de trabajo es múltiple, por ende este "mote" que ha recibido por parte de la crítica de prensa especializada no es el único o el gran elemento definitorio de su poética (303-305).

11 [Cita original]: "Discourses, far from being solely linguistic, are built with icons, indexes, and symbols, elaborated in the form of analogical, expressive, and logical articulations. Though them agents understand their actions and the surrounding circumstances, and which guide or motivate their subsequent actions".

12 [Cita original]: "Communication is a productive practice. Since communication produces various effects, 
En Neva, el mecanismo principal, develado a lo largo del montaje, es el teatro en sí mismo. Los actores, una y otra vez, ejecutan juegos de representación en distintos niveles, ya que, al final de cuentas, la obra pone en el escenario a actores que actúan de actores y que, a su vez, están actuando y "dejando de actuar" repetidamente. La elección de instalar la metateatralidad como estrategia predominante en esta puesta en escena no es más que la apuesta directorial por tratar de develar la propia esencia del teatro en sí mismo: "El Metateatro, sobre el que podría estar tentado a concluir, que es la esencia pura del teatro; el teatro relevado de todas las demás obligaciones, excepto de la celebración de sí mismo" (12). ${ }^{13}$ Surge, entonces, la necesidad de reparar en qué lleva a Calderón a instalar la pregunta por la propia condición material del teatro en esta primera obra; es decir, por qué y cómo la metateatralidad puede constituirse a sí misma como una metodología de trabajo escénico. Tobin Nellhaus propone, a este respecto, que la metateatralidad puede ser entendida como una metodología para el trabajo de creación escénica, ya que, por una parte, produce una creación, mientras que también, por otra, dota y provee de significado: "La preocupación de la producción [de las obras metateatrales] generan algo nuevo, una variedad de significados, emociones y sensaciones en una audiencia; se refieren a los efectos que no se puede considerar en el acto de habla y en la performance porque no se realizan a menos que logren algún efecto sobre esa audiencia" (151). ${ }^{14}$

La metateatralidad, entendida como una estrategia de dirección, demanda de una reflexividad que deja al descubierto la ilusión y la artificialidad del teatro en sí mismo, por medio del ejercicio actoral. Para Mary Ann Frese Witt, toda pieza metateatral se sitúa en una mise en abyme, en una situación de espejo que demanda autenticidad por parte de sus participantes; en este caso, de los actores: "La cuestión de la autenticidad se convierte en lo primordial. Jugando un papel en el metateatro, un actor puede ser más auténtico que los que están fuera del teatro jugando hipócritamente papeles en lo que pasa en la realidad" (171171). ${ }^{15}$ Esta sería, precisamente, la operación directorial que Calderón propone en Neva;

including meanings and interpersonal or social relations, one can accomplish things by communicating [...] every speech act, and communication in general, is performative".

13 [Cita original]: "Metatheatre, we might be tempted to conclude, is the pure essence of the theatre, the theatre relieved from all other obligations except from celebrating itself".

14 [Cita original]: "The concern [the metatheatrical's plays] production because they generate something new, an array of meanings, emotions and sensations in an audience; they concern effects because no speech act and no performance can be considered performed unless it achieves some effect upon that audience".

15 [Cita original]: "The question of authenticity becomes primary. Playing a role in the metatheatre, an actor may be more authentic that those outside the theater hypocritically playing roles in what passes for reality". 
su propia metodología es revelada en una mise en abyme de sí misma. Por tanto, el propio montaje se convierte en memoria y encarnación del trabajo metodológico realizado durante los ensayos. En este caso, sería utilizar la metateatralidad para escenificar cómo el personaje quiebra la artificialidad de la representación, para insertarse como actor -o actor/personaje como propone Nellhaus- y, así, trasladar la escena desde "lo real" hacia el artificio: "Cuando los personajes en el escenario eliminan el aparato creacional ilusorio para revelarse a sí mismos como actores, y al escenario como un lugar de representación de un palacio o una sala de estar, se mueven, paradójicamente, de lo irreal a lo real a lo irreal" (172). ${ }^{16}$

La gran paradoja de la metateatralidad consiste en que más real -o verosímil- se plantea la obra cuanto más abiertamente abraza el artificio. Como bien ocurre en Neva, cuando Aleko le declara su amor a Olga, pero en realidad estaba actuando; Olga se muestra desolada, y cuando Aleko trata de consolarla, ésta también revela que se encontraba actuando:

ALEKO: Olga, le quiero pedir perdón.

OLGA: ¿Por qué, Aleko?

ALEKO: Porque me enamoré de usted cuando la vi actuar Las Tres Hermanas hace un par de meses en Moscú. Me enamoré tanto, Olga, que me orino en la cama.

OLGA: Aleko, yo ya amé, yo ya quemé mi carbón y mi aceite.

ALEKO: Entonces sálveme, Olga, perdóneme. Yo le deseaba la muerte a su Antón y mi deseo se cumplió. Olga, por favor, perdóneme; soy una persona tan simple. Por favor, perdóneme, Olga.

MASHA: Permiso, voy a buscar hielo.

ALEKO: ¡No, no te vayas! ¡No me dejes solo con ella! Olga, soy una costra [...]. El órgano más importante de mi cuerpo es mi apéndice y quiero metérselo en su riñón y verla sudar.

MASHA: ¡Aleko!

OLGA: Siga, siga [...].

ALEKO: No, ya terminé.

OlgA: Sucio, boquita de postre. No me puedo mover.

ALEKO: Es un monólogo que estoy ensayando basado en Dostoievski. ¿Le gustó? $[\ldots]$.

OlgA: ¿No me ama? (Olga llora).

16 [Cita original]: "When the characters on stage remove the illusion-making apparatus to reveal themselves as actors and the stage as a stage rather than a representation of a palace or a living room, they are, paradoxically, moving from the unreal to the real to the unreal". 
ALEKO: No. (Consolándola) Olga, Olga, cualquiera se enamoraría de usted. OLGA: ¿Estaba actuando?

ALEKO: Sí.

OLGA: No actúe nunca más, por favor (Olga pasa bruscamente del llanto a la risa).

MASHA: (Sorprendida) Olga, usted es muy buena actriz.

OLGA: No. Era (19-20).

Pareciera que en este juego metateatral, en que los actores actúan para dejar de actuar y volver a actuar después, radicaría no sólo la paradoja propuesta por Mary Ann Frese Witt, sino que también la esencia misma del acto teatral, ya que:

El contacto entre los cuerpos vivos en el escenario y una audiencia en vivo -o incluso imaginando la performance en la lectura "literal" de teatro- todavía tiene el potencial para ofrecer una experiencia transformadora que los medios más sofisticados técnicamente no lo hacen. Teatro que se refleja sobre sí mismo como el teatro que seguirá manteniendo el poder de la magia teatral (173-174). ${ }^{17}$

Es en este sentido la propuesta directorial de Calderón, en Neva, no hace más que entender la propia exégesis del teatro al querer revelar $-\mathrm{y}$ al conseguirlo exitosamente- en escena la propia naturaleza del teatro, porque como bien considera Martin Puchner: "Si entendemos el metateatro como el momento cuando el teatro viene hacia sí mismo, ya no es sorprendente, sino que es casi imposible para el teatro no convertirse en metateatro. Porque, ¿cómo podría cualquier teatro, no sé, de alguna manera, y demostrar que sabe, de alguna manera, lo que significa ser teatro?” (13). ${ }^{18}$ En consecuencia, para lograr este cometido, es que Calderón apela a un "ultra-naturalismo" -en términos de Nellhaus-, para poder escenificar la meta-reflexividad que Neva propone como pieza escénica: "Esta implosión teatral hacia lo que realmente está presente en el momento de la actuación podría, estéticamente hablando, ser nombrada como un estilo de ultra-naturalismo" (176). ${ }^{19}$ Bajo la considera-

17 [Cita original]: "The question of authenticity becomes primary. Playing a role in the metatheatre, an actor may be more authentic that those outside the theater hypocritically playing roles in what passes for reality".

18 [Cita original]: "If we understand metatheatre as the moment when theatre comes to itself, it is no longer surprising that it is almost impossible for the theatre not to become metatheatre. For how could any theatre not know, somehow, and show that it knows, somehow, what it means to be theatre?".

19 [Cita original]: "This theatrical implosion into what is actually present at the moment of performance might, aesthetically speaking, be called a style of ultra-naturalism”. 
ción de una puesta en escena fascinante y sugestiva, la metodología directorial descansa en considerar a los actores como agentes del verbo y de una self-presence -o reflexividad de la presencia en sí misma- para instalarnos en un nivel ontológico de sentido.

Conforme a esto, la performance de la performance da cuenta de un nivel metadiscursivo ulterior que, en este caso, corresponde al mensaje final de la obra, encriptado en el monólogo final de Masha, interpretado por Paula Zúñiga. La estructura teatral que componen los actores/agentes durante toda la obra es una preparación para este momento, en donde la obra da un salto o giro ontológico, en el que los agentes virtuales -personaje Masha- se desplazan hacia agentes reales -actriz Paula Zúñiga interpelando al público presencialmente real-. Y es, justamente, en este salto/giro/desplazamiento en donde es posible vislumbrar el quiebre con el artificio que había sido abrazado previamente durante todo el montaje; he ahí aquel punto en donde "lo real" hace mella la escena, para irrumpir con profunda fuerza a través del trabajo de dirección actoral.

\section{"Lo real" como improvisación para una metodología actoral}

En Neva, Calderón ejecuta un cuestionamiento sobre la naturaleza de la acción teatral, en cuanto a su condición de verdad y artificialidad. A lo largo de la obra, los actores cuestionan los métodos de actuación proscritos para su época, dadas las condiciones interpretativas, supuestamente extraordinarias, de Olga Knipper; el talento para la improvisación lúdica por parte de Aleko, y las limitadas -en teoría- dotes actorales de Masha.

El proceso de ensayo -según afirma el propio Guillermo- parece no tener una lógica preestablecida, aunque a la luz de los años y tras varios montajes a su haber, es posible refutar esta primera impresión del teatrista chileno:

Metodología no hay, pero sí una forma que se repite, aunque no alcanza a definirse [...] Una vez que está la idea y los actores van a actuar, comienza la etapa de escribirla. Voy escena a escena. Por lo general cuando al final, al principio y lo que sucede en el medio. Escribo las escenas, y en los ensayos me interesa ver cómo los actores van reaccionando al texto, voy escribiendo a partir de eso. Por ejemplo, pueden haber cosas que a ellos no les resuenan mucho, es decir, está muy vinculado a quienes lo van a interpretar. Hay mucha edición de puesta en escena, y es que me voy adaptando a ellos, como dije antes, a sus reacciones (citado en Baboun 22-23).

En cada ensayo, Calderón busca establecer un mapa de la memoria de los cuerpos en escena; es decir, como director registra las pequeñas reacciones que los actores van 
teniendo en cada ensayo y, a partir de ellas, continúa construyendo las escenas del montaje. Aunque la estructura total ya haya sido trazada en su globalidad, los ajustes y el devenir de la pieza en sí van siendo creados en su trabajo de dirección en los ensayos en conjunto con los actores.

Para Isabel Baubon, el trabajo de ensayo de Calderón "parece convertirse en una actividad de prueba donde la materia prima o primera sustancia corresponden al actor, como un sí mismo indisoluble entre texto y escena. Es el actor quien instala preguntas, conflictos y oposiciones entre el primer paso o traspaso de la escritura, siendo el carácter y reacción del propio intérprete esencial para nuevas texturas y decisiones de estilo" (ibídem 23). El texto, por ende, adquiere una densidad mnemotécnica, gracias a la capacidad de recordarse a sí mismo a través del trabajo de improvisación actoral realizado en cada ensayo: "Podemos incluso identificar sin realizar un difícil rastreo, palabras y formas del decir en los personajes, acusando un metalenguaje que posibilita todavía más la relación de ellas entre sí" (23).

"Lo real" aparece en su propia condición metodológica en cuanto metalenguaje escénico que busca poner en crisis su propio contexto de producción; vale decir, a la obra de arte en sí misma o, en este caso, al propio teatro. A este respecto, para Adorno: "En virtud de la contradicción entre este objeto conciliado en la imagen (es decir, espontáneamente acogido por el sujeto) y la exterioridad objetiva inconciliada, la obra de arte critica la realidad. En esto consiste su conocimiento negativo de la realidad" (52). En el caso de Neva, el objeto conciliado en la imagen -a la que alude Adorno- no sería otro que el cuerpo de los actores. Éstos, por medio de su actuación, mediada por el trabajo de dirección de Calderón, consiguen aquella exterioridad objetiva inconciliada; en el ejercicio de hablar y de hacer teatro en el acto de reflexionar sobre el mismo, como bien ocurre en la serie de juegos representacionales que suceden a lo largo de la obra. Es así que "lo real" irrumpe en escena: "Sólo en virtud de esta diversificación y no en virtud de su negación, la obra de arte se hace a la vez obra de arte y justa conciencia. Una teoría del arte que lo ignore es simultáneamente vulgar e ideológica" (52).

La metodología directorial que Calderón persigue -conscientemente o no- en Neva descansa en el ejercicio de referenciar el propio teatro a partir del trabajo de improvisación actoral que vaya sucediendo en los ensayos. En este sentido, la metodología se transforma en el propio metalenguaje que todo el tiempo está en un diálogo intrínseco con el self de la obra. Como el propio director declara:

En el teatro contemporáneo es casi inevitable metalenguajear, hacer referencia al propio lenguaje de una forma autorreferente, irónica. No puedo plantearme tan ingenuamente frente al medio en el que estoy inmerso, tengo que referirme a él. Y hacerlo 
no es pensarlo como vanidoso, sino más bien como una reflexión necesaria al propio trabajo. Ponerlo en crisis, enfrentarlo al escenario, cuestionarlo como un elemento dentro de una totalidad y no como algo fundamental, que muchas veces ocurre donde la obra entera está definida por una relación conflictiva del lenguaje escénico, lo que puede ser interesante, pero que a mí no me parece tanto como para definir así una obra entera (citado en Baboun 23).

La capacidad de realizar esta labor se ve facilitada por el conocimiento previo que Guillermo Calderón tiene para con los intérpretes, en particular con las actrices Trinidad González y Paula Zúñiga, con quienes no sólo había trabajado previamente, sino con quienes también creó la Compañía El Cancerbero. Después de un par de años, Calderón y González viajaron a Estados Unidos para seguir perfeccionándose, situación que también hizo Zúñiga, por su parte, quien viajó a India e Italia. Una vez que ambas actrices regresaron a Chile, quisieron trabajar juntas nuevamente, pero se les había unido el actor Jorge Becker. En un comienzo, la primera motivación de Guillermo Calderón fue llevar a escena Las muertes de Chejov, ya que venía hace ya varios años fanatizando con la literatura rusa, y llegó a la primera reunión con los actores solamente con el monólogo inicial de Olga Knipper con el que comienza, de hecho, la obra.

Las demás escenas surgieron -tal como él declaró en la entrevista realizada por Baubouna partir del proceso ligado a los ensayos. Calderón tenía clara una idea, en donde había tres actores que hablaban y hacían teatro, pero aquello de lo que hablarían y cómo lo personificarían surgió en un proceso basado en el trabajo de improvisaciones realizado con los actores a partir de una escaleta estructural de la obra que ya existía desde un comienzo, pero que se fue construyendo en su totalidad -salvo el final que Calderón tenía claro desde un principio-durante el proceso de montaje (Corbalán 1-6). A raíz de esto, podría pensarse que, al ser un texto escénico que surge en gran parte a partir de los procesos de ensayo, hubo creación colectiva coral con los actores. Pero, más bien, el fenómeno transitivo que aquí ocurrió fue de un proceso de "inspiración" o feedback dramatúrgico que se dio tras los ensayos, por el desempeño de los actores, quienes iluminaron el trabajo escritural de Calderón. Por tanto, el director no escribió para cualquier actor, sino que lo hizo directamente enfocado con los tres intérpretes con los que trabajó: González, Zúñiga y Becker.

"Lo real" aflora, bajo este prisma, como la presencia de lo relacional mediado por el proceso de improvisación y réplica que los actores propusieron en cada ensayo, puesto que lo real es, en sí, relacional. El teatro, dentro del teatro, como estado de encuentro: "La esencia de la práctica artística radicaría entonces en la invención de relaciones entre sujetos; cada obra de arte encarnaría la proposición de habitar un mundo en común, y el trabajo de cada artista, un haz de relaciones con el mundo que a su vez generaría otras relaciones, y así hasta 
el infinito" (15). Calderón restableció, en su trabajo con los actores, un espacio de encuentro en el proceso de creación artística e invitó al espectador a sumarse al mismo. Puesto que, como él afirma -en diálogo con Soledad Lagos-, éste debió ser un ente activo en el proceso interpretativo de la obra: "Hay gente que se frustra un poco, porque piensa que necesita más tiempo para digerir cada idea, pero la idea era que fuera un flujo, que fuera más una impresión general que caer en la tentación de lanzarle al público textos predigeridos" (Tres actores 8). Es el espectador quien debía decidir desde dónde emergía la obra para él, pues Neva se compuso como un devenir discursivo de ideas bajo la premisa de conseguir "que fuese una angustia apabullante y que dejara en crisis al espectador, sin que él supiera si abordar eso de modo intelectual o emocional, para que quedara una especie de neblina" (8).

En Neva, Calderón realizó un trabajo de puesta en escena, en donde documentó el propio proceso de los ensayos. Como bien rescatan Paula Zúñiga y Trinidad González, la obra visualiza de manera patente los propios hallazgos que el grupo descubrió y trabajó durante los ensayos. Bajo esta consideración, la obra se pliega a los procesos artísticos de hacia finales de los años 90 y principios del siglo xxi que, como indica José A. Sánchez, no buscan romper definitivamente con lo espectacular o lo objetual, como ocurría en la década de los 60, por ejemplo, sino que intenta proponer lo espectacular y lo objetual como generadores de la acción: "es el objeto [...] el que provoca la acción de aquel o aquellos con quienes entra en relación a quienes anima una relación y una organización formal, y es finalmente esa organización formal la que cumple el objetivo de la obra artística" (278). Por tanto, este devenir de ideas se encarna en los actores para producir una organización formal generadora de un momento de sociabilidad con su audiencia, siendo ella la última encargada de decidir cómo abordar el objeto artístico; en este caso, la significancia ulterior del montaje en sí. Cabe rescatar, empero, que también existe una posibilidad inversa: "la consideración del objeto o del espectáculo en cuanto documento de un proceso de relaciones previas, sin que de ello se deduzca la total desvalorización de lo que se muestra al final, y que se contempla más bien como límite, y no como huella, pero tampoco como resultado o producto" (278). Calderón da cuenta de esta otra consideración en su entrevista con Soledad Lagos, al constatar las diversas apreciaciones que la variedad de público puede proscribir para con Neva: quedarse con la historia de una viuda que llora a su marido, de actores que actúan de actores, o con el conflicto político-ideológico que reflexiona sobre la violencia y la revolución social del pueblo.

Aunque podría decirse que operan, al unísono, una simultaneidad de significancias y consideraciones con las que los espectadores podrían quedarse tras ver el montaje, Calderón realiza un último gesto de dirección que termina por entregar una pista clave al público a la hora de otorgarle un sentido global a la pieza: el gesto de la estufa. Una vez terminado el apabullante monólogo de Masha -en donde ésta increpa a Olga y Aleko por su aparente escaso entendimiento de que está a punto de escribirse una revolución popular sangrienta 
y de que el teatro no sirve de nada para cambiar la Historia-, se produce un instante de silencio pequeño. Zúñiga ha acabado de interpretar un monólogo extenso que en apariencia no ha terminado, pues lo ha interrumpido al "dejarse caer" a un costado de la pequeña tarima, desapareciendo de escenario; en ese momento, Bécquer gira la pequeña estufa -que ha estado iluminando a los actores durante toda la obra- hacia el público, encandeciéndolos brevemente, antes de ejecutar el apagón final. Este último gesto teatral cobra suma importancia, pues el acto de "cegar" al espectador -aunque sea momentáneamente- se consigna como la última acción performática del montaje.

La realización de este gesto final brinda al espectador una clara pista con respecto al propósito ideológico que el monólogo de Masha ha suscitado y se consigna como una clara acción que busca incluir al público en la propia discusión que la obra ha planteado. Este gesto es de suma importancia no sólo para el fin de análisis del Neva, sino que es clave para toda la obra de Calderón, puesto que -como se verá a continuación en este y el próximo apartado- las obras de Guillermo muestran un patrón común: el de finalizar con un gesto escénico rotundo, con una acción particular y específica, desprovista de texto. Después del viaje emocional y de la lluvia de ideas, que Calderón ha propuesto durante todo el montaje, la decisión de cerrar con este gesto escénico profundo y tajante, puede ser traducida como una decisión de dirección, en que se busca cerrar la cadena significante de la obra dotándola del sentido ideológico que se ha estado persiguiendo a lo largo de todo el montaje. Es así que el gesto metateatral final se transforma "en Neva" en el epítome de la reflexividad escénica que el teatro de Guillermo Calderón trabajará en sus siguientes montajes.

\section{Más allá del sentimiento: la emoción y el uso de la voz}

En Neva, Calderón instala -como ya se ha mencionado anteriormente- un teatro de las ideas, en donde plasma sus reflexiones ideológicas y políticas sobre el teatro, el amor y la revolución social. ${ }^{20}$ Este ejercicio se instala desde una práctica prominentemente metateatral, en la que fue clave el trabajo de improvisación con los actores durante el proceso de ensayo. Pero también parece importante rescatar que este "teatro de ideas" no debe ser entendido solamente como un ejercicio de reflexividad, sino como un flujo

20 En la entrevista "Neva: Tres actores en escena, una estufa, algunas sillas. Diálogo entre Guillermo Calderón y Soledad Lagos a propósito de Neva", realizada por Soledad Lagos, Calderón comenta que en el caso de esta obra persiguió dar cuenta de dos ideas políticas que confluían dentro de él y que se plasman en los personajes de Masha y de Aleko. Estas serían: la revolución social anarquista, destinada a la muerte de sus partidarios en los gulag, y el sueño retrospectivo tolstiano de segregarse al campo para abrazar la vida pastoril. 
emocional que encarnan los actores en escena. Un claro ejemplo de que este tránsito desde las ideas hacia las emociones ocurre hacia el final de la obra es el monólogo de Masha. Para Calderón, este tránsito es de suma importancia y da cuenta de una intención clara que persigue a lo largo de toda su obra; frente a este trabajo -en conjunto con la actriz Paula Zúñiga- declara:

Cuando ella tomó el monólogo, quería hacer lo que se hace de manera convencional, que es poner una idea detrás de cada texto, de tal modo que el texto quedara comprendido y explicado, pero mi indicación fue que fuera una especie de... que se subiera a un carro, digamos y se fuera con ese carro, que hubiera un flujo emocional más que un flujo intelectual. Mi idea era que, como espectador, uno se cuelgue de una emoción y que escuche esta idea intelectual, pero que no sepa con exactitud por cuál camino irse: si quedarse con lo intelectual o lo emocional, y que se produzca una experiencia un poco apabullante, que vaya más allá de lo racional (citada en Corbalán 7).

Surge, entonces, la pregunta de cómo trabajar este flujo emocional con la actriz y desde la actriz hacia el público presente. Es, en este momento, que el uso de la voz se convierte en un vehículo para ello.

Bunch Dayme considera que el trabajo con las emociones en teatro es sumamente difícil, pero de vital importancia: "Las emociones pueden curar, o crear el caos con el campo de energía [...]. La emoción es un tema que por lo general se ignora o se omite, ya que es difícil de cuantificar" (6-7). ${ }^{21}$ Frente a este problema de cuantificación emocional, Bunch concluye que el ejecutante debe trabajar con un observador externo que lo ayude a encontrar una emoción pura con la cual el espectador pueda empatizar:

Para que el intérprete pueda escuchar de esta manera, se exige un desprendimiento completo; casi la de un estado mediador o la de una tercera persona que ve desde el exterior. Como el "observador", el intérprete también puede entonces permitir que el sonido usado para contar su propia historia sin interferencias, esto debido a que la producción simultánea y la percepción de la misma forma emocional no pueden ser llevadas a cabo por el sistema nervioso y sin un grado de interferencia. Las formas puras emocionales inducen la empatía y se experimentan como "sinceridad" por el público (7). ${ }^{22}$

21 [Cita original]: "Emotions can heal, or create chaos with the energy field [...] Emotion is a topic that usually is ignored or omitted because it is difficult to quantify".

22 [Cita original]: "For the performer to be able to listen in this way, demands complete detachment; almost that of a mediative state or that of a third person viewing from the outside. As the 'observer', the perform- 
Desde la perspectiva de Bunch, la emoción aflora gracias a un trabajo vocal que busca instalar un uso natural de la voz. En este sentido, una vez que el actor "suena natural", puede liberarse a sí mismo y dejar correr la emoción, para que: "Entonces toda esa energía fluirá en una palabra, una frase y una necesidad de llegar al mundo, simplemente a través de una combinación de sonido y el lenguaje" (Rodenburg 26). ${ }^{23}$ Esta "voz natural" no debe ser entendida como una voz "no teatral", sino más bien como un recurso teatral en donde la voz se trabaja desde la propia naturalidad y singularidad de cada intérprete, sin intentar forzarla, engolarla o disfrazarla hacia otra voz (26-28). Es desde este mismo entendimiento sobre los tratamientos del trabajo vocal que Guillermo Calderón realiza su trabajo de dirección actoral en Neva: contraponiendo una propuesta de naturalización del uso de la voz en los personajes de Masha, Olga y Alejo con otra propuesta del uso de la voz un poco más engolada y teatral una vez que estos interpretan otros personajes.

Para lograr este cometido, el trabajo vocal debe ser preciso en su repetición para que se pueda transmitir con claridad la idea a comunicar. A este respecto, Calderón ha declarado que las ideas son cruciales en su teatro. Por tanto, la manera en que éstas son transmitidas es sumamente importante, tal como argumenta Clynes:

Performear/actuar de forma natural significa dos cosas: [1] escuchar interiormente con la máxima precisión a la forma interna de cada sonido musical; y [2] producir esa forma precisa. Lo cual significa tener una idea precisa, así como una ejecución precisa de la misma. Y el hecho crucial y sorprendente es que si uno realmente cree esto y escucha con gran cuidado, entonces también resulta ser algo hermoso (12). ${ }^{24}$

La emoción se vuelve la base axiomática desde la que los actores construyen sus personajes en Neva, guiados por la dirección de Guillermo Calderón. En este sentido, puede afirmarse que, en este montaje: "Resulta que la memoria es en realidad una proteína"

er can then allow the sound to tell its own story without interference because simultaneous production and perception of the same emotional form cannot be carried out by the nervous system without a degree of interference. The pure emotional forms induces empathy and is experienced as 'sincerity' by the audience".

23 [Cita original]: "Then all that energy will flow into a word, a sentence and a need to reach out to the world, purely through a combination of sound and language".

24 [Cita original]: "Performing naturally means two things: [1] to listen inwardly with utmost precision to the inner form of every musical sound, and [2] the to produce that form precisely. It means to have a precise idea, as well as a precise execution of it. And the crucial and amazing fact is that if one really believes this and listens with great care, then it also turns out to be beautiful". 
(Bogart xviii), ${ }^{25}$ en sintonía con entender que la verdadera raison d'être del teatro no es otra que proveer de sentimientos al público. En el caso del teatro calderoniano, se propone la construcción de una emocionalidad con sentido, ideológica y afectivamente erguida desde un lugar político o, como él mismo lo ha definido, un teatro de las ideas.

La producción del trabajo emocional en Neva no es -en lo absoluto- una labor sencilla. En palabras de Erin Hurley: "Si la emoción se construye en la relación entre la escena y la audiencia (el estímulo y el receptor, si se quiere), no puede ser simplemente proyectada por los actores y capturada como la misma emoción, por parte del público. El trabajo emocional del teatro, es, en parte, una negociación" (20). ${ }^{26}$ Durante toda la obra existe un constante juego metateatral, en el que los personajes saltan de un personaje a otro; por ejemplo, Aleko interpreta a Chéjov, o Masha es la hermana de éste, siendo dicho juego revelado frente a los espectadores. Este juego es -en la terminología de Hurley- la negociación que Calderón pacta desde la dirección de actores hacia la audiencia, un juego que es ejecutado desde un trabajo emocional mediado por el uso de una voz natural. En Neva -y en el resto de sus obras-Calderón apela por una apuesta de naturalización del registro vocal, en la que el uso de la voz trata de asemejarse lo más posible a la voz natural que cada uno de los intérpretes -González, Zúñiga y Becquer- poseen en su vida cotidiana.

La claridad en el uso de la voz - como una instrucción de dirección que puede ser vista en toda la obra del autor- repercute no sólo en un acercamiento a lo real dentro de la construcción escénica, sino que también hay en ella una puesta en valor de la emoción que cada uno de los actores siente y reproduce función a función. Esto no es sólo trabajado desde la dirección y la puesta en escena, también desde el tratamiento dramatúrgico por parte de Calderón. La claridad del lenguaje en el texto dramático busca ser plasmada, asimismo, en la escena, ya que: "La claridad del lenguaje es crucial, pues es un reflejo directo de la claridad en la relación con la imagen y la acción. Si el lenguaje cambia o no está claro, la imagen cambiará o no será clara; y esto se manifiesta en el cambio de falta de claridad en la acción, que es una consecuencia y respuesta a la imaginación" (Boston 134). ${ }^{27}$ Es así que la claridad del lenguaje -tanto en el texto dramático como en la ejecución performática del mismoprovee al actor de una situación desde donde trabajar la emoción por medio de la acción y

25 [Cita original]: "It turns out that memory is actually a protein that is formed in the heat of experience".

26 [Cita original]: "If emotion is made in the relationship between stage and audience (the stimulus and receiver, if you will), it cannot simply be projected by actors and caught as the same emotion by the audience. The theater's emotional labour, the, is, in part, a negociation".

27 [Cita original]: "Clarity of language is crucial, for it is a direct reflection of clarity in relationship to image and action. If the language changes or is unclear, then the image changes or is unclear; and this manifests itself in changor lack of clarity in the action, which is an outgrowth of and response to the imagination". 
la naturalización vocal, para reflejar una imagen que podría ser entendida como la "idea de base" ${ }^{28}$ desde la que Calderón articula todos sus trabajos.

Por medio del uso vocal de un registro natural, Calderón busca liberar la voz para producir en el espectador una comunicación expresiva instalada, al mismo tiempo, en un plano emocional, y en otro, racional. Esta situación es llevada a su nivel máximo de ejecución durante el monólogo final de Masha, que indica que: "[el uso de] La voz natural libre es transparente: expresa, mas no describe, nuestros impulsos sentipensantes (de sentimientos y pensamiento) en forma directa y espontánea. De esta manera, escuchamos a la persona, no simplemente su voz" (Ocampo 18). Así, Calderón da los primeros pasos en busca de una recursividad sonora natural a través del registro vocal de sus actores en escena, recurso que seguirá trabajando en sus siguientes piezas y que radicalizará como técnica, a medida que avanza su carrera como director.

\section{Breve reflexiones de cierre (o la revalorización tradición teatral)}

A partir de una escena que juega desde el despojo escénico, consignado en el minimalismo escenográfico y lumínico, Calderón propone una dramaturgia de la palabra, ${ }^{29}$ del sonido en que "el poder expresivo se basa en la interminable relación conflictiva entre visualidad y auralidad reflejada en el choque entre la forma de las letras y el sonido de los fonemas, entre el texto escrito/impreso y la pronunciación vocal" (Ovadija 19). ${ }^{30}$ A través de una profunda preocupación por la palabra, articula una propuesta que se centra en el trabajo de dirección con los actores, sin forzarlos a emocionarse ni a ser grandilocuentes, casi en un

28 Por "idea base" me refiero a la situación común en el trabajo de Calderón, quien a partir de una idea primaria construye todo su universo teatral. En la entrevista "Neva: Tres actores en escena, una estufa, algunas sillas. Diálogo entre Guillermo Calderón y Soledad Lagos a propósito de Neva”, Calderón cuenta que su modo de trabajo nace a partir de una idea que él busca trabajar íntegramente al situarla en contexto con sus actores.

29 Es concordante que Juan Andrés Piña destaque que: "En este contexto, no es extraño que Calderón haya sido saludado como un [autor] de la renovación, por trabajar sobre la base de una poderosa verbalidad, para estructurar con ella un universo reflexivo y atento a los acontecimientos del mundo y de Chile, y capaz de formular interrogantes a las verdades recibidas. Todas sus obras se sostienen en largos parlamentos que los personajes se dicen a sí mismos o a los demás, creando con ello una singular poética que va desde la apagada sordina interior hasta alcanzar niveles épico” (168-169).

30 [Cita original]: "expressive power builds on the endless conflicting relationship between visuality and aurality reflected in the clash between the shape of letters and the sound of phonemes, between written/ printed text and vocal utterance". 
acto performático de resistencia a la teatralidad, en pos de organizar el sonido de la palabra dicha como única protagonista. Por tanto, "al concebir un método de composición o construcción teatral que diga su propia 'trama' a través del proceso de una semiosis oral/aural, la dramaturgia del sonido se ha convertido en constitutiva de un teatro que pone más énfasis en la performance, la puesta en escena y la arquitectura audio-visual del escenario, que en relación al texto dramático" (19). ${ }^{31}$

Podría enunciarse que -a final de cuentas - el trabajo de dirección que Calderón ha establecido - desde sus inicios hasta la fecha- instala una cartografía de la palabra escénica a partir de un cuidado tratamiento de la voz natural con los actores, cada vez más radicalizado en sus montajes -llegando al uso de microfonía en sus últimos trabajos para no 'forzar' la voz de los intérpretes-. Acompañándose -en el caso concreto de Neva-, de un minimalismo escénico y de una serie de recursos metadramáticos que persiguen revalorizar un modelo teatral fundador del teatro moderno chileno: "el del realismo sustentado en la complicidad estética entre Antón Chéjov y Stanislawski” (Hurtado, Prólogo 44).

Pues bien, estos recursos metateatrales no son más que, en esta lógica, una recursividad política, en la cual Calderón se instala desde una posición autorreferencial como agente (Nellhaus), pero no sólo para hablar de sí mismo, sino también para instalar un proceder dialógico crítico con respecto a aquello que le rodea; vale decir, estando siempre lo metateatral al servicio de un proyecto mayor, como la crisis de la memoria, lo íntimo y lo político, todas ellas trampas y equívocos que el imperativo de esta tradición metodológica-realista deja -según Calderón- en sus intérpretes. Para el autor, los espacios personales de sus actores son emplazamientos políticos que problematizan los métodos operativos escénicos de la herencia stanislavskiana. Y es por esto que, en Neva, las operaciones dramatúrgicas pretenden confrontar, en su evidencia, las limitaciones que el mismo método -como metonimia del propio teatro- ofrece. En escena, el director plasma las vicisitudes del trabajo actoral -ejercicios respiratorios, olvidos de textos, ensayos infructuosos- que cuestionan la efectividad de los métodos de actuación y se preguntan afectivamente por el sentido del teatro para los sujetos que -como Aleko, Masha y Olga- se encuentran en contextos supeditados por la crisis. Aquí se yergue, en síntesis, un doble gesto de parte de la autoría; el primero descansa en la comprensión de que, para aprehender a cabalidad el presente teatral, es necesario atender a su herencia, y el segundo, que sólo es posible proponer nuevas formas

31 [Cita original]: "Conceiving a method of theatrical composition or construction that tells its own 'plot' through the process of an oral/aural semiosis, the dramaturgy of sound has become constitutive of a theatre that places more emphasis on performance, mise en scène, and the audio-visual architecture of the stage than it does on dramatic text". 
de producción en el entramado cultural, una vez que los aparatos que soportan dicha herencia son puestos en tensión para su desarticulación afectiva, como propone Masha en su última intervención.

Pero, pese a esta resistencia contra las formas teatrales o contra el teatro en sí -como bien consigna el monólogo final-, sus obras siempre finalizan -paradójicamente- en un gesto escénico - muy teatral en varios casos- que termina por completar el sentido de cada uno de sus montajes; en el caso de Neva, una actriz que se precipita al vacío y una estufa que es volteada hacia los espectadores, cegándolos. Es en este gesto donde la comunión entre palabra y escena ocurre, en un último instante escénico, donde la acción y el gesto rodean a la palabra dicha. En este abrazo se funde el teatro de Calderón, un teatro que batalla contra sí mismo y contra la tradición que lo fundamenta, mientras lucha, a su vez, contra la memoria, la historia y el olvido a orillas de un río llamado Neva.

\section{Fuentes consultadas}

Adorno, Theodor W. "Lukács y el equívoco del realismo”. Realismo: ¿Mito, doctrina o tendencia histórica? Buenos Aires: Tiempo Contemporáneo, 1969, pp. 37-85.

Avelar, Idelber. Alegorías de la derrota: La ficción postdictatorial y el trabajo de duelo. Santiago de Chile: Cuarto Propio, 2000.

Baboun Garib, Isabel. "Guillermo Calderón: Tres motivos para una poética casi trágica”. Revista Apuntes, 131, 2009, pp. 20-28.

Bogart, Anne. "Foreword". Theatre E Feeling. Erin Hurley. London: Palgrave Macmillan, 2010, pp. ix-xv.

Bourriaud, Nicolás. Esthétique relationnelle. Dijon: Presses du réel, 1998.

Boston, Jane. "Poetic Text in Contemporary Voice Training: a Repositioning". Voice and Speech Review, vol. 8, núm. 2, 2014, pp. 131-148.

Calderón, Guillermo. "Neva”. Teatro I. Santiago: LOM, 2012, pp. 9-52.

Campos Arancibia, Carolina. "Neva de Guillermo Calderón. Reflexiones en torno a un teatro que se plantea desde, en y como teatro". Tesis de Licenciatura en Lengua y Literatura Hispánicas, Universidad de Chile, 2014.

Clynes, Manfred. Sentics: The Touch of Emotions. New York: Doubledat Anchor, 1989.

Corbalán Herrera, Ana. "Un encuentro de camarín con Trinidad González y Paula Zúñiga, actrices de la Compañía Teatro en el Blanco (Neva y Diciembre), durante sus funciones en el FiBA 2009". Telón de Fondo 10 (diciembre 2009), pp. 1-16, www.telondefondo. org/numeros-anteriores/numero10/articulo/240/un-encuentro-de-camarin-con-trinidad-gonzalez-y-paula-zuniiga-actrices-de-la-companiia-teatro-en-el-blanco-ne- 
va-y-diciembre-durante-sus-funciones-en-el-fiba-2009.html, consultado el 15 de noviembre de 2018.

Dayme, Bunch. Dynamics of the Singing Voice. Austria: Springer Wien New York, 2009.

Goic, Cedomil. Historia y crítica de la literatura hispanoamericana. Volumen 3. Barcelona: Crítica, 1988.

Hurley, Erin. Theatre E Feeling. London: Palgrave Mcmillan, 2010. Consultado el lunes 26 de noviembre de 2018.

Hurtado, María de la Luz. "Prólogo: 1990-2010: De autorías escénico-dramáticas y textuales en la indagación de lo real desde la subjetividad". Antología: Un Siglo de Dramaturgia Chilena. Tomo IV. Eds. María de la Luz Hurtado y Mauricio Barría. Santiago: Publicaciones Comisión Bicentenario, 2010. pp. 11-47.

Hurtado, María de la Luz. "Teatro chileno del siglo xx: de cuerpos mutilados a la representación ficcional/textual de la muerte o de su enigma”. Antología de teatro chileno contemporáneo, editado por María de la Luz Hurtado. La Habana: Casa de las Américas, 2008, pp. 7-48.

Frese Witt, Mary Ann. Metatheater and Modernity. Baroque and Neobaroque. Maryland: Fairleigh Dickinson University Press, 2014.

Lagos, Soledad. “Neva: El río de la Historia”. Revista Apuntes, núm. 129, 2007, pp. 13-18.

Lagos, Soledad. "Neva: Tres actores en escena, una estufa, algunas sillas. Diálogo entre Guillermo Calderón y Soledad Lagos a propósito de Neva". Telón de fondo, núm. 6, 2007, pp. 1-9, www.telondefondo.org/numeros-anteriores/numero6/articulo/124/neva-tres-actores-en-escena-una-estufa-algunas-sillas-dialogo-entre-guillermo-calderon-y-soledad-lagos-a-proposito-de-neva-.html, consultado el 26 de noviembre de 2018.

Larraín, Javiera. "Hacia una poética directorial de Guillermo Calderón: Una cartografía de la palabra escénica”. Tesis de Magister en Artes, Universidad de Chile, 2018.

Nellhaus, Tobin. "Chapter 4. Social Ontology, (Meta)Theatricality, and the History of Communication". Theatre, Communicatin, Critical Realism. New York: Palgrave MacMillan, 2010, pp. 143-181.

Ocampo Guzmán, Antonio. "Introducción". La libertad de la voz natural. El método Linklater. México: UNAM, 2010, pp. 17-35.

Opazo, Cristián. “Clase, de Guillermo Calderón: ensayo de pedagogía chilena”. Revista de Crítica Literaria Latinoamericana, 72 (2010), pp. 17-30.

Oyarzún, Carola. "Entre el teatro y la vida”. Antología: Un Siglo de Dramaturgia Chilena. Tomo IV, editado por María de la Luz Hurtado y Mauricio Barría. Santiago: Publicaciones Comisión Bicentenario, 2010, pp. 303-305.

Oyarzún, Carola \& Opazo, Cristián. "Viajando y buscando eternamente". Revista Theater Der Zeit, núm. Especial (2008), pp. 18-24. 
INVESTIGACIÓNTEATRAL

Revista de artes escénicas y performatividad

Vol. 10, Núm. 15

abril-septiembre 2019
El diálogo afectivo con la tradición

en el teatro chileno reciente

Javiera Larraín George

Ovadija, Mladen. Dramaturgy of Sound in the Avant-Garde and Posdramatic Theatre. Canadá: McGill-Queen's University Press, 2016.

Piña, Juan Andrés. "Verbalidad, política y poesía en el teatro de Guillermo Calderón". Estudios Públicos, núm. 152, 2015, pp. 165-182.

Puchner, Martin. "Introduction". Tragedy and Metatheatre. Essays on Dramatic Form. New York: Holmes \& Meier, 2003, pp. 1-24.

Rodenburg, Patsy. The Right to Speak. Working with the Voice. London: Methuen, 1992.

Sánchez, José A. Prácticas de lo real en la escena contemporánea. Ciudad de México: Paso de Gato, 2013.

Villegas, Juan. Historia multicultural del teatro y las teatralidades en América Latina. Buenos Aires: Galerna, 2005. 


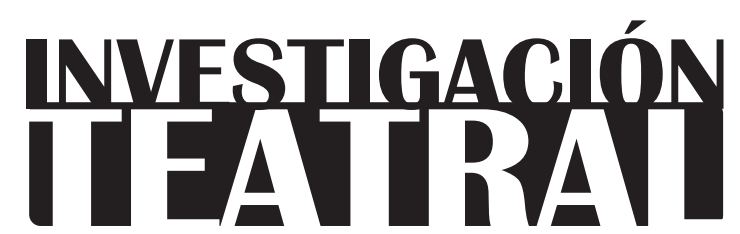

Revista de artes escénicas y performatividad

Vol. 10, Núm. 15

abril-septiembre 2019

Segunda época

ISSN impreso: 1665-8728

ISSN electrónico: 2594-0953

Universidad Veracruzana

\title{
Metateatralidad y recepción en el texto dramático del teatro español barroco
}

\author{
Ximena Gómez Goyzueta*
}

\footnotetext{
* Departamento de Letras del Centro de las Artes y la Cultura, Universidad Autónoma de Aguascalientes, México/Asociación Internacional de Teatro Español y Novohispano de los Siglos de Oro (aitenso).

e-mail:ximenaggoizueta@gmail.com
}

Recibido: 31 de octubre de 2018

Aceptado: 10 de enero de 2019 


\title{
Metateatralidad y recepción en el texto dramático del teatro español barroco
}

\section{Resumen}

Este trabajo propone una reflexión sobre la teatralidad y el metateatro desde el punto de vista de la recepción lectora del texto dramático. Se revisan postulados teórico-metodológicos sobre la teatralidad y el metateatro, así como su relación con el tópico del theatrum mundi, en el contexto del horizonte de expectativas del teatro español del siglo xviI. Con ello, se proponen algunas pautas metodológicas sobre el análisis de la recepción a partir de los efectos que pudo haber producido el uso del metateatro en estos corpora y que, en la actualidad, pueden afectar positivamente la captación de la atención del receptor/espectador.

Palabras clave: teatralidad, percepción, efectos, lectura, horizonte de expectativas, Theatrum Mundi.

\section{Metatheatricality and the Reception of the Dramatic Text in the Spanish Baroque Theater}

\begin{abstract}
This article purports to reflect on theatricality and metatheatre from the point of view of the reading reception of the dramatic text. Theoretical-methodological postulates about metatheatre and its relationship with the subject of Theatrum Mundi are reviewed in the context of the "horizon of expectations' of seventeenth-century Spanish theater. A number of methodological guidelines are proposed for the analysis of reception, considering the effects that metatheatre may have had on these corpora, which at the present time can positively contribute to catch the attention of the receiver/viewer.
\end{abstract}

Keywords: theatricality, perception, effects, reading, horizon of expectations, Theatrum Mundi. 


\section{Metateatralidad y recepción en el texto dramático del teatro español barroco ${ }^{1}$}

La cuestión no es saber de qué forma atraerlos [a la gente de teatro] hacia nuestras teorías, sino -modestia aparte-cómo influirán éstas en su práctica, del mismo modo en que su práctica ha motivado nuestras teorías.

Pavis, El análisis de los espectáculos

E presente ensayo se centra en el texto dramático para discurrir sobre la teatralidad y el metateatro con base en la relación que puede establecerse entre este último y el tópico del theatrum mundi. Hablaré de su recepción a partir de algunos mecanismos metateatrales que surgen en él y que pueden activar una percepción determinada de éste en una lectura analítica.

Para contextualizar la discusión teórica sobre el análisis del texto dramático, mi propuesta de lectura tomará en cuenta algunos postulados teórico-metodológicos del horizonte teatral, que permitirán generar una ruta metodológica con la que se puedan reflexionar y comprender algunos aspectos del fenómeno de la recepción en el teatro aurisecular y su actualización. Estos postulados parten, por un lado, de planteamientos semiológicos que se han hecho sobre el estudio de la teatralidad y su posible activación en la lectura del texto dramático desde su espectacularidad, los cuales han sido propuestos por María del

1 La investigación de este trabajo ha sido financiada por la SEP a través del programa PRODEP de Apoyo a la Incorporación de Nuevos Profesores de Tiempo Completo 2017-2018. 
Carmen Bobes Nabes en Semiología de la obra dramática, Óscar Cornago en su introducción a Estética de lo performativo de Erika Fischer-Lichte, y Carmen Leñero en La escritura invisible. Del faro al foro.

Parten también, por otro lado, de las consideraciones de Patrice Pavice sobre la necesidad de estudiar la composición artística y la puesta en escena de la dramaturgia, con base en el contexto histórico que le dan sus peculiaridades. Sin esta perspectiva, cualquier reflexión teórico-metodológica del texto dramático parecería sesgada. Además, estos postulados se relacionarán con algunas de las propuestas del "proceso de lectura" de Wolfgang Iser, con el objetivo de establecer las conexiones imprescindibles entre el horizonte de expectativas del repertorio del texto aurisecular y el horizonte de expectativas de una posible lectura crítica actualizada. Esto nos permitirá pensar de manera compleja el tema de la concreción de la obra, es decir, el lugar de encuentro (virtual) entre el texto y el lector desde la perspectiva que nos interesa en este artículo: la de la identificación de los posibles efectos que la metateatralidad puede producir en el lector, a partir de la cosmovisión del tópico del theatrum mundi barroco, pero que también se encuentra vigente en nuestro tiempo con las propuestas artísticas de las "nuevas teatralidades".

Para contextualizar el tema del metateatro en relación con el theatrum mundi, propongo una revisión a partir de los estudios pioneros de Lionel Abel en Metatheatre, que relacionan el tema con los tópicos de la vida como sueño y el mundo como teatro. Recurro también a una la lectura de El teatro y la teatralidad del barroco de Emilio Orozco (que aborda la misma cuestión en contexto del barroco español), así como a la recopilación de testimonios textuales de diversos ámbitos socio-culturales (el eclesiástico, el letrado, el de los propios poetas dramáticos) que hace José Hesse en Vida teatral en el Siglo de Oro, sobre la percepción de la teatralidad de la vida en la España aurisecular.

Asimismo, en la evolución del metateatro, retomo las propuestas más relevantes de Richard Hornby en Drama, Metadrama and Perception, que serán fundamentales para su comprensión no sólo especulativa, como en el caso de Abel, sino también de uso metodológico en el análisis. Igualmente, retomo el criterio sociocultural de Diez Borque en "Teatro español del siglo XVII", sobre la pluralidad de espacios de representación que son como un escenario, y la vida como un sueño.

Finalmente, para mi propuesta de análisis y crítica, me apoyo en las ideas de José Luis García Barrientos en Cómo se comenta una obra de teatro, quien retoma a Hornby desde la dramatología, sobre las distinciones entre el tratamiento especulativo del metateatro a partir de la cosmovisión del theatrum mundi y la identificación de técnicas metateatrales, así como de los niveles que puede desplegar el texto dramático desde el engaste metateatral.

Las siguientes reflexiones sirven como introducción a este panorama. El texto dramático es producto de la imaginación teatral, del modo particular en que el escritor concibe 
su obra. Carmen Leñero considera que "el espacio donde surge una pieza dramática es en principio un teatro interior - un ámbito virtual- en la conciencia del autor, quien, de entrada, imagina en términos espaciales, tridimensionales" (Del faro al foro 51-52). Así, la teatralidad emerge en el texto dramático que "fue motivado, destinado y modelado para su virtual realización escénica [...], ya sea que tal ulterior escenificación se lleve a efecto o no" (25).

De esta actividad creadora de la teatralidad se desprende, a su vez, "una manera específica de interpelar al prójimo, estableciendo un vínculo distintivo no sólo entre el autor y el lector (o espectador) sino también entre las voces que el autor vehicula y aquellas con las que el lector convive en su interior" (37).

Respecto al tema del receptor, Patrice Pavis hace una contraposición entre la concepción sociológica, empírica, del público, frente a la psicoanalítica o cognitiva del sujeto percibiente teórico (Diccionario de la performance 109), y argumenta que ésta debería ser superada. Pero el presente trabajo la tendrá en cuenta, como una distinción pensada a partir de momentos y recepciones diferentes del fenómeno teatral.

Propongo hacer un primer acercamiento a la recepción a partir de una lectura hermenéutica del texto dramático, que proporcione algunas claves para poder entender esta "manera específica de interpelar al prójimo" en relación con el metateatro. Para ello, reflexionaré sobre ciertos aspectos metodológicos que se involucran en esta lectura: la metateatralidad en la composición del texto dramático y sus probables efectos con base en la percepción que pueda tener un lector. Tras esta revisión, podrá establecerse un punto de partida más para un análisis del texto dramático, que tenga en cuenta la puesta en escena a partir de la metateatralidad.

\section{El teatro, el metateatro y la recepción}

Está visto que el metateatro y la autorreflexibilidad, son parte de la discusión teórica y de la práctica de "las nuevas teatralidades", están presentes desde el teatro clásico grecolatino y el teatro moderno occidental. Ello se debe, podemos decir, a que las implicaciones dramá-

2 Actualmente, menciona Ileana Diéguez, la teatralidad puede ser entendida "como instinto de transfiguración capaz de crear un ambiente diferente al cotidiano, de subvertir y transformar la vida, tal como lo planteó Nicolás Evreinov cuando estudiaba las disposiciones escénicas de la sociedad, interesado en observar 'el espectáculo sin fin' de la existencia humana y los roles sociales, más cercano a la premisa shakespeareana del mundo como un gran teatro y a buscar cada detalle que revelara 'la incesante teatralización de la vida" (párr. 17). Los artistas y los estudiosos de las "nuevas teatralidades" están considerando a partir de estas ideas, en términos generales, que la teatralidad del teatro se desprende de este "instinto de transfiguración" del ser humano, que es parte de su condición de homo ludens. 
ticas y escénicas de estos dispositivos, más allá de ser propias de convenciones históricas de la teatralidad, forman parte, en mayor o menor grado, de su lenguaje intrínseco. Así se manifiesta en obras que utilizan el metateatro temática y estructuralmente: el Anfitrión de Plauto, The Tempest de Shakespeare o Lo fingido verdadero de Lope de Vega, por mencionar algunos ejemplos (ver Abel, Metatheatre).

Es posible percibir en la lectura de estas obras cómo se pone de manifiesto el funcionamiento de sus propios mecanismos dramáticos, de manera que "hacen referencia a sí mismas". Esto puede presentarse en una puesta en escena o una performance, según Pavis, en tres formas generales: "puede tener que ver con la ficción de la obra (en cuyo caso se habla de metaficción), con su construcción (y deconstrucción) o con su temática (alusión, teatro dentro del teatro)" (Diccionario de la performance 48).

Ante este amplio panorama, la intención es buscar las formas en las que podemos percibir la metateatralidad en algunos textos dramáticos del Siglo de Oro español, los cuales ubicaremos según su momento histórico y las circunstancias de la representación, para así poder entender y concebir su recepción desde este punto de vista. En este sentido, Óscar Cornago piensa, a propósito del trabajo de Erika Fischer-Lichte, que:

hacer teoría como un modo de construir una forma de mirar, de tomar distancia para desarrollar una perspectiva de estudio (de representación), es un modo de estar en un presente, es una manera de ser histórico y dialogar con la historia desde un espacio y un lugar concretos, desde un aquí y un ahora, desde un cuerpo (Estética de lo performativo 14).

No propongo hacer una teoría sobre la metateatralidad, pero sí, tomando en cuenta esta reflexión, proponer algunos presupuestos sobre la lectura teatral que permitan entender los posibles efectos de la metateatralidad -dispositivo muy presente, por demás, en el teatro áureo-. ${ }^{3}$

Asimismo, es importante tener presente la siguiente afirmación de Erika Fischer-Lichte: "[...] las definiciones de teatro nunca se refieren a la esencia del teatro, más bien son consideradas como instrumentos en función de las distintas finalidades del análisis en el marco de una determinada teoría" (11). Para poder detectar la metateatralidad en la lectura del texto dramático, es necesario considerar ciertos puntos de partida teórico-metodológicos

3 Estos mecanismos que aparecen en el texto dramático pueden o no aparecer en la puesta en escena; además, como producto del trabajo de dramaturgia de la representación o como producto de la improvisación actoral, pueden aparecer otros mecanismos metateatrales que no están en el texto dramático. Es por ello que dejaremos para otra fase de esta investigación el cotejo y análisis de la puesta en escena. 
que ayuden a "adoptar una noción amplia de teatralidad -en tanto que modalidad de pensamiento y expresión que busca recuperar lo corpóreo, lo multidimensional y lo potencial-". Esta idea de Carmen Leñero "se desprende de una reflexión semiológica sobre lo teatral, cuyo objeto básico es 'el acto en situación', es decir, aquel cuya representación 'se da a ver"' (La escritura invisible 23).

Discurrir sobre una posible lectura del texto dramático que rastree su recepción con base en el metateatro significa, para esta investigación, tener presente la doble vida temporal de las obras: la de su momento histórico y la de su actualización en la lectura y en la representación. Pavis señala que "[...] la teoría del texto dramático deberá ser verificada por consideraciones históricas sobre la obra analizada" (“Tesis para el análisis" 9). Para cualquiera de los dos casos, teatralidad y metateatralidad en el texto dramático involucran al lector a través de un proceso de traducción del lenguaje de las palabras al de las acciones imaginadas. No obstante, es importante aclarar que, al hablar de la lectura del teatro español áureo en su momento, no hay que perder de vista la dificultad de poder rastrear esta actividad de recepción. Al respecto, Diez Borque deja muy claro lo siguiente:

si complejo es el problema del público en los distintos espacios de representación, en que hay posturas críticas encontradas, en las que no hace caso entrar aquí, no lo es menos, aunque sea incitación apasionante, el problema de la recepción del teatro impreso. A todos nos gustaría que hubiera respuestas satisfactorias a preguntas, entre otras, tan importantes como ¿quién leía el teatro?, ¿cuáles eran las relaciones entre lectura y representación?, ¿qué proporción ocupaban los libros de teatro en las bibliotecas?, ¿en qué medida condicionaban la clase social, el precio?, y tantas otras preguntas. Pero suele ocurrir que no haya respuestas a la altura del interés de las cuestiones (Literatura 80).

Por ello, en este trabajo reconstruiremos el horizonte de expectativas del texto dramático con base en el topos barroco del theatrum mundi en la sociedad de aquella época y su uso en el teatro, para desde allí proponer reflexiones metodológicas sobre una lectura metateatral de estas obras. Para esto último, asumimos una operación cognitiva de carácter científico e intelectivo, puesto que el lector, con su propio horizonte y el del texto, debe disponer su atención de manera especial ante un texto que fue imaginado por el dramaturgo para su representación. Así, la percepción de la teatralidad del texto puede activarse en un primer nivel más o menos inmediato, el del lenguaje propio del teatro. Las palabras encarnan

4 Si bien esta concepción de la teatralidad que propone Carmen Leñero está considerada en función de textos no dramáticos, es pertinente y útil para el interés de este trabajo, puesto que parte de reflexiones sobre "la imaginación teatral" y el "modo de lo teatral". 
en personajes que, por este "darse a ver", adquieren tridimensionalidad en la imaginación tanto del escritor como del receptor, es decir, movimiento, voz, tono, acción... De esta manera, entran en juego estas voces conducidas por el dramaturgo que, a su vez, adquirirán su propia dimensión en la imaginación del receptor.

La percepción de la metateatralidad se activaría en un segundo grado de reconocimiento, que, como dijimos al principio, dependerá de cada lectura particular, pero sin perder de vista la necesidad de establecer las coordenadas espacio-temporales que le dieron vida a ese texto. Esto es así porque, como señalan Nara Araújo y Teresa Delgado a propósito de la teoría de la recepción, "la forma de leer los textos literarios ocurre en un proceso ininterrumpido, y la lectura expresa, hasta cierto punto, la inagotabilidad de ellos, condición de la realización individual en aquélla" ("El proceso de lectura" 486).

Antes de seguir, es importante tener en cuenta las siguientes precisiones de Lilian von der Walde sobre la polisemia del texto a partir de la pluralidad de lecturas. Von der Walde dice que hay que:

subrayar la obligación del especialista de poner verdaderos límites a su "recepción"; esto es, apegarse a lo que realmente aparece en la composición de que se trate, mediante una lectura sumamente cuidadosa y el análisis, obviamente, de la recepción de la época en la que fue escrita y copiada. [Así pues], por ningún motivo el crítico, en virtud de su libertad receptiva, debe "completar" al autor, volverse una suerte de coautor (4).

Asimismo, los siguientes cuestionamientos de Pavis sobre el análisis del texto dramático son relevantes para una adecuada delimitación del proceso de recepción teatral:

¿Es [...] legítimo hablar del texto dramático en general? ¿No convendría mejor hablar de la dramaturgia, ese arte de la composición de obras que tiene igualmente en cuenta la práctica teatral? Habría, entonces, que situar esta dramaturgia en la historia, verificar si ella es clásica, romántica, realista, absurda, etc. Del mismo modo que resulta problemático hablar del teatro, en general, no sabríamos hacer la teoría del texto dramático en sí. Debemos considerarla en su marco histórico específico; por lo tanto, la teoría del texto dramático deberá ser siempre verificada por consideraciones históricas sobre la obra analizada ("Tesis para el análisis" 9).

Si, como Pavis, pensamos el texto dramático como dramaturgia -es decir, en su sentido artístico y partiendo de su historicidad-, podemos apoyarnos para nuestra propuesta en algunos de los postulados sobre la recepción en "El proceso de lectura" de Wolfgang Iser: 
La obra literaria posee dos polos que podemos llamar polo artístico y polo estético, siendo el artístico el texto creado por el autor, y el estético la concreción realizada por el lector. El lugar de la obra de arte es la convergencia de texto y lector, y posee forzosamente carácter virtual, puesto que no puede reducirse ni a la realidad del texto ni a las disposiciones que constituyen al lector (487).

Tenemos, así, dos elementos en el proceso de lectura: la dramaturgia o el texto dramático y el receptor. Éstos se reúnen en el acto de lectura, del cual se genera la realización de la obra de un modo virtual. El acto de lectura se constituye, dice Iser, bajo las "reglas de juego" de "un juego de fantasía" que tiene lugar en el texto a partir de "lo no dicho" por parte del autor, de los "vacíos en las revueltas del diálogo" (488-489).

Estos vacíos son, según García Barrientos, “característicos del género [teatral]”. El lector los llenará, dice el crítico, a través de una reconstrucción y "con ayuda de su imaginación, hasta cierto punto, de los cuatro elementos inherentes al teatro (texto y representación): unos personajes en un tiempo y un espacio que se muestran para un receptor (lector o público). Esto corresponde a lo que él llama "una lectura teatral de la obra dramática" (39), es decir, "reproducir mentalmente una representación de la misma" (40). La dramaturgia se constituye, entonces, dice Carmen Leñero, "en una especie de territorio ceremonial y opera como mediador entre la referencia abstracta y la experiencia sensible, participando así de la llamada 'magia teatral': encarnar lo ausente, darlo a ver y permitir que ello actúe en el espectador" (La escritura invisible 27).

Si bien Von der Walde señala que debemos ser cuidadosos para que ese "llenado" por parte del receptor no se convierta en un acto de libre interpretación y recreación del texto al servicio de la pura imaginación, para el caso del texto dramático dicha reproducción mental de la virtual puesta en escena responde esencialmente a la naturaleza del acto comunicativo propio del género. A propósito de ello, María del Carmen Bobes ha hablado del teatro como "fenómeno literario y como fenómeno espectacular, en su doble dimensión de texto escrito y texto representado" (14). Esta doble dimensión implica que

el texto dramático inicia un proceso de comunicación que no culmina en la lectura, ya que se prolonga hasta la representación, siempre colectiva. La representación no es algo añadido al texto y ajeno a él, ya que está virtualmente incluida como algo constitutivo del mismo texto. Esta circunstancia condiciona todo el modo de recepción, como es lógico, pero también condiciona fuertemente la creación y la forma del texto literario dramático, es decir, afecta a todo el proceso semiótico y a sus partes (17). 
Esto significa que, aunque no seamos actores y directores leyendo la dramaturgia para ponerla en escena, solemos leerla en una doble dimensión: la literaria y la espectacular, es decir, haciendo - como señala García Barrientos- una lectura teatral. De allí que el ejercicio lector de imaginar la virtual representación, siempre teniendo presente el horizonte de expectativas del texto, sea necesario para estudiar este género.

El horizonte de expectativas del texto tiene que ver, dice Iser, con que "todo texto literario incorpora, en mayor o menor medida y con más o menos intensidad, normas sociales, históricas y contemporáneas, y las correspondientes referencias a la tradición literaria. Forman lo que se llama el repertorio del texto" ("El proceso de lectura" 504). De manera que la "lectura teatral de la obra dramática” tiene que tomar en cuenta este repertorio, para poder evitar, así, el uso exclusivo de "las normas familiares". Por tanto, proponemos hacer una virtual representación del texto dramático que sea pertinente, en este caso, bajo un repertorio que hemos considerado desde el metateatro en la España áurea del siglo XVII.

\section{El metateatro}

Según ha identificado la crítica, el metateatro aparece en los textos dramáticos desde dos perspectivas. Por un lado, la ya clásica, planteada por Abel, que ve al metateatro como un "género" de obras en las que los personajes viven la "vida" como ya teatralizada (el mundo como teatro y el teatro como escenario del mundo). Ésta es de carácter especulativo, pues implica el modo en el que los personajes son construidos para reflexionar sobre su entorno y sobre sí mismos a partir de la metáfora del theatrum mundi.

Por otro lado, tenemos la perspectiva que se manifiesta, específicamente, a través de técnicas metateatrales por parte de los dramaturgos, y que pueden percibirse en la estructura del texto y en relación con los personajes y la acción. Estas técnicas son, en términos generales, el teatro dentro del teatro, la representación de más de un papel por un solo personaje y la autoconsciencia dramática (Hornby, Drama 82; Larson, "El metateatro" 1015).

Así también, José Luis García Barrientos establece, más o menos, la misma distinción entre el modo especulativo (el mundo como teatro y el teatro como escenario del mundo) y el modo de las técnicas dramáticas del metateatro. El modo dramático está constituido, propone él, de tres formas: el metateatro, el metadrama y la metadiégesis. El metateatro es "la forma genuina del teatro en el teatro que implica una puesta en escena teatral dentro de otra" (232). El metadrama es:

un concepto más amplio, que incluye el anterior, pero que rebasa todas aquellas manifestaciones en que el drama secundario, interno o de segundo grado se escenifica 
efectivamente, pero no se presenta como producido por una puesta en escena, sino por un sueño, un recuerdo, la acción verbal de un narrador (Ibídem).

Y la metadiégesis corresponde a "una fábula secundaria, argumento de segundo grado o historia dentro de otra historia" (Ibídem). Sobre el modo especulativo, García Barrientos señala que es:

el reflejo de estas categorías formales en el plano del contenido [...] De este mismo modo caen también, me parece, algunas de las que Hornby considera variedades de metadrama, como los personajes actuando dentro de personajes o las ceremonias dentro de la obra. [...] El carácter reflexivo o especular que les es común puede tematizarse sin afectar a la estructura dramática [...] o bien puede formalizarse en la estructura (niveles), con mayores o menores consecuencias (incluso ninguna) (234).

En la práctica teatral, la distinción entre estas dos visiones del metateatro puede no ser clara. En relación con esto, cito a Jesús G. Maestro:

al contrario de lo que sucede en la expresión metapictórica, como en las Meninas, por ejemplo, ante las que el espectador puede contemplar simultáneamente los diferentes planos reflejados por el pintor, el espectáculo metateatral no siempre permite observar con la misma facilidad o intensidad [que la metapintura] las dos escenas que se representan en simultaneidad de tiempo y en identidad o contigüidad de espacio (599).

Esta dificultad es igualmente problemática para la lectura del texto dramático. Puede ocurrir que cualquier aspecto del texto sea interpretado a través de estas modalidades sin que, efectivamente, exista allí metateatro. Por ejemplo, en su apartado dedicado a la "visión" o a aquello que "afecta a la recepción dramática" (Cómo se comenta 193), García Barrientos refiere también el ejemplo de las Meninas para hablar de los "niveles dramáticos" a propósito del "teatro en el teatro". García Barrientos identifica tres niveles: "extradramático, el cual equivale al plano escénico; intradramático, equivale al plano ficticio; y metadramático, equivale al drama dentro del drama" (231). Estas distinciones teóricas son claras, pero al momento de la lectura, la identificación del metateatro dependerá del texto en cuestión y de que el mecanismo metateatral se active en la percepción del lector.

Es necesario tener en cuenta, durante el proceso de lectura, unos instrumentos de análisis que nos permitan no ver metateatro en cualquier punto que nuestro deseo imaginativo nos haga reaccionar. "A esta propensión un tanto paranoica sólo cabe oponer el criterio de la sensatez o la pertinencia, más fácil de aplicar que de definir", observa García 
Barrientos (233). Esto nos lleva a pensar no sólo en esclarecer los procedimientos del metateatro, sino también en intentar identificar indicios de su posible recepción.

Para Catherine Larson, el metateatro no es una metodología per se, ni es tampoco una teoría, "aunque podríamos decir que la forma de entender el fenómeno sí es una herramienta interpretativa" (1015). Esto significa que, en cierta medida, si se trata de una forma de entender e interpretar un aspecto del funcionamiento del teatro, entonces se está considerando una forma de recepción que en buena medida depende de la percepción o la mirada del receptor y de su repertorio personal, pero -en la lectura hermenéutica que proponemos- también del repertorio del texto dramático. Así, surgen algunas preguntas: ¿Cómo es percibido esto por el lector?, ¿cuáles son los efectos que produce el metateatro?; si se producen ciertos efectos, $\dot{i}$ se distinguen consecuentemente estos dos modos de metateatralidad: el especulativo y el dramático?

Para intentar responder estas preguntas, adoptaremos una postura crítico-analítica, situándonos principalmente en el punto de vista de nuestra propia recepción con base en la concepción psicoanalítica o cognitiva del sujeto percibiente teórico, que mencionamos al inicio a propósito de Pavis. En la perspectiva de la estética de la recepción, esta postura se entiende como intrínseca al texto dramático, es decir, el horizonte de recepción se reconstruye no de forma empírica, sino a partir de los "blancos" y de los indicios que el propio texto otorga y de su repertorio. La siguiente propuesta metodológica es la que asumimos seguir en análisis posteriores para los fines que buscamos en este artículo.

Decíamos, líneas atrás, que el primer "nivel" que se abre ante el lector es el de la teatralidad, el de la "reconstrucción de la obra dramática" - diría Barrientos-. En este nivel, podemos considerar que el acto de lectura comienza a realizarse a partir de las expectativas tanto del dramaturgo como del lector: la realización virtual de un texto artístico escrito para su representación. El segundo nivel, el del metateatro, depende de que el receptor comience a advertir en su lectura la presencia de más de un nivel dramático en el texto.

Ahora bien, debemos preguntarnos cuáles son las coordenadas de las obras que proponemos analizar y de su recepción. A partir de estas reflexiones, esta investigación continuará de la siguiente manera: analizar la recepción del metateatro en el teatro áureo con base en una lectura que parta del repertorio del texto. Ésta se hará según la metáfora barroca del theatrum mundi, tanto desde el plano de la forma como desde el contenido. Así, sería posible realizar una reconstrucción que diera cuenta de algunos indicios sobre cómo pudo haber sido la recepción de lo metateatral. Los resultados de esta lectura podrían ser una posibilidad más para ver al metateatro como uno de los dispositivos más recurrentes en el teatro español áureo, en buena medida, como producto de su entorno social e ideológico. Esto apoya la idea de que pueda ser considerado como un mecanismo de producción de sentido en la espectacularidad; propuesta que, a su vez, permite ver al teatro áureo como 
generador de interesantes perspectivas para su estudio y montaje, así como considerarlo en relación con el teatro actual. Pues el metateatro es un mecanismo que, tanto en aquel momento como en la contemporaneidad, involucra al lector-espectador de manera activa, en una lectura o una puesta en escena que lo motiva y lo cuestiona sobre la posición que ocupa en ella y más allá de ella.

\section{El horizonte del teatro español barroco}

En general, el teatro barroco europeo se realizó sobre el influjo cultural de distintos tópicos (ser/parecer ser, el mundo al revés, la mujer vestida de hombre, engañar con la verdad, entre otros). Uno de los más presentes es el del theatrum mundi. Al respecto, cito el siguiente planteamiento de Erika Fischer-Lichte:

El teatro barroco aparece como un tema elegido para su estudio, ya que la concreción de la teatralidad, la actualización de las correlaciones entre el teatro y la cultura de su entorno, en ninguna otra época de la historia teatral occidental se pone tan evidentemente como condición para la posibilidad de teatro actualizado. Cuando se puede encontrar la metáfora dominante y característica del Barroco en todas partes del topos del theatrum mundi, del teatro vitae humanae. En él aparecen el «teatro» y el «mundo», o sea la «vida humana», como dos dimensiones relacionadas entre sí, que sólo pueden caracterizarse y comprenderse adecuadamente mediante la referencia a su relación recíproca (Semiótica del teatro 299).

Esta consideración plantea los puntos de contacto que pueden hallarse entre la visión del teatro barroco desde este tópico, así como su permanencia y vigencia en las teatralidades actuales: su presencia o uso permite establecer una relación directa de actualización entre el teatro y la realidad que le da espacio y tiempo. En el caso de España, Emilio Orozco (El teatro y la teatralidad del barroco) y José Antonio Maravall (La cultura del barroco) han hablado ampliamente sobre el teatro y la teatralidad del barroco como un modo de ser, que se constituía como parte de la realidad cotidiana de los españoles que habitaban principalmente las urbes en las que el teatro tuvo su mayor auge: Madrid, Sevilla, Zaragoza, Valencia.

Este modo de vivir y concebir la realidad podía reflejarse en el teatro, hasta cierto punto, desde en los detalles de su nivel más cotidiano (a través de la comedia de capa y espada, por ejemplo), hasta en la teatralización deliberada de la corte o del mundo en el auto sacramental por parte de los poetas, autores de comedias y comediantes. "Se produce un 
verdadero desbordamiento de lo teatral, no sólo de su sentido y expresividad, sino también de sus mismas formas" (Orozco 171).

Esta cosmovisión era también un "credo estético" para la poética del barroco, la cual pone de manifiesto el carácter ficticio de la realidad e interpreta al mundo mediante las parábolas de "la vida como sueño" y "el mundo como un teatro" (García Gutiérrez 863864). Tenía también un sustento teológico de raigambre medieval, que en la época barroca encontró en el teatro uno de sus mejores medios de expresión. Ello se entendía desde las dos grandes visiones filosóficas de Occidente: la platónica y la aristotélica. Así lo menciona Austin O'Connor:

En la filosofía idealista de Platón nada puede ser real, ya que todo es reflejo de alguna esencia eterna. La epistemología de Aristóteles modificó esta visión, y el papel de la razón, en su sistema, elevó la realidad a niveles de respetabilidad, ya que, mediante la razón, el hombre podría llegar a la verdad, la cual era eternamente distante dentro de la cosmología de Platón. ${ }^{5}$

Santo Tomás de Aquino retoma las ideas de Aristóteles y plantea los fundamentos de la cosmovisión cristiano-medieval del mundo: "St. Thomas Aquinas founding his system on Aristotle, asserted that reason could arrive at truth; but some truths are beyond the capacity of man's reason, and therefore God's revelation aids and points out divine truth directly" (Ibídem). La España del siglo XVII es el escenario de encuentro entre estas dos visiones cristiano-medievales: "In Spain this Neo-Platonism was grafted on an Aristotelian-Thomistic stem, which was a holdover from the Middle Ages" (279). Es un hecho que el teatro español reflejó esta perspectiva de una forma innovadora en relación con el antropocentrismo de los dramaturgos ingleses y franceses. Fue la Contrarreforma católica la que condicionó esta realidad plenamente barroca desde el theatrum mundi para los españoles del teatro áureo.

For the Spanish dramatists the world is indeed a stage — but a real stage- - [...] The man who "plays" a part is unauthentic, false and inevitably doomed to deceive himself about the nature of reality. The man who is true to his Christian faith is not an actor; he is a man being proved and tested by God (Ibidem).

5 In Plato's idealist philosophy nothing could be real since all is a mere reflection of some eternal essence. Aristotle's epistemology modified this view, and the role of reason in his system elevated reality to a levels of respectability since, by reason, man could arrive at truth -some eternally distant in Plato's cosmology (278). 
Además de la teatralidad ideológica con la que se vivía la vida en España, este sentir está en el teatro áureo -entre otras cosas- porque gracias al gran éxito que adquirió su representación fue un fenómeno que tuvo como "uno de los rasgos más destacables [...] la pluralidad de espacios exteriores, interiores y profesionales" (Diez Borque, "Teatro español” 139). El espacio donde se representa el teatro, dice también Diez Borque:

no es cuestión accesoria y sin importancia [...], pues afecta, naturalmente, a la puesta en escena, supone una pluralidad de "géneros canónicos", distintas órbitas de teatralidad y, obviamente, implica una variedad de "públicos", lo que es fundamental para entender hoy nuestro teatro clásico (Ibidem).

Esta reflexión es importante, por un lado, para distinguir la manera en que este teatro era entendido en su momento en relación con el nuestro (hablando, en general, del teatro occidental). Al respecto, dice Diez Borque: "El lugar privilegiado y fundamental de difusión del teatro es el teatro y no el espacio privado de la biblioteca, que implica, además, en el caso del teatro español del Siglo de Oro, una heterogeneidad de públicos" (Literatura 82). Y podemos completar esta idea con la siguiente de Felipe B. Pedraza: "Tengamos en cuenta que, aunque hoy haga las delicias de innumerables lectores, la comedia no fue creada para la lectura. Su vida estaba en la escena, en la voz y en el gesto del actor" (115). Por otro lado, este auge permite rastrear la presencia que tenía el teatro en el imaginario de la España barroca. Al respecto, dice también Pedraza:

[...] también llegó la pasión por el teatro a ciudades de menor población (Almagro, Alcalá, Écija...) e incluso a los pueblos. Existió una tupida red de teatros que permitía que las compañías ambulantes recorrieran toda España representando cada día. Hoy conocemos razonablemente bien muchos de esos espacios teatrales y la vida y el arte que en ellos se desarrollaban (109).

Así pues, podemos decir que la intensidad de la actividad teatral resultaba ser un factor fundamental para que los españoles de esta época sintieran al teatro como parte importante de sus vidas, según lo plantean Orozco y Maravall en sus clásicos estudios. Es así que, efectivamente, en el teatro español áureo uno de los tópicos recurrentes (ya en su temática, ya en los dispositivos dramáticos) fue el del theatrum mundi.

A este respecto, tenemos la recopilación de José Hesse de testimonios de distintas procedencias sobre el teatro áureo en Vida teatral en el Siglo de Oro, donde se cita a letrados, poetas dramáticos, comediantes, preceptistas, religiosos, notarios, testimonios anónimos, etcétera. Entre todos los que conforman el libro, podemos destacar un tes- 
timonio sobre los espacios que ocupaban los espectadores en el corral, la descripción sobre la división por estrato social y las tretas de la alta nobleza. Por ejemplo, los reyes se divertían no sólo con la representación, sino también con los apuros entre mujeres y mosqueteros, ${ }^{6}$ en ocasiones provocados por los nobles. Son éstos buen ejemplo de la teatralidad que va más allá de las tablas:

El 14 de septiembre los Reyes se entretienen en el Buen Retiro oyendo la comedia en el Coliseo, donde la Reina nuestra señora, mostrando gusto de oírlas silbar, se ha ido haciendo con todas, buenas y malas, esta misma diligencia. Asimismo, para que viese todo lo que pasa en los corrales en la cazuela de las mujeres, se ha representado bien a lo vivo mesándose y arañándose unas, dándose vaya otras y mofándose los mosqueteros. Han echado entre ellas ratones en cajas que, abiertas, saltaban; y ayudando este alboroto de silbatos, chiflos y castraderas se hacen espectáculo más de gusto que de decencia (Hesse 75).

Otros testimonios similares los proporciona Juan Zavaleta en El día de fiesta en Madrid y sucesos que en él pasan. ${ }^{7}$ Allí se describe graciosamente la vida cotidiana de los madrileños para "ir a la comedia" durante un día entero, desde la mañana hasta el suceso completo de la representación. La siguiente descripción pone en evidencia la antesala del espectáculo, desde la organización del acomodo de los espectadores, hasta la preparación de los comediantes detrás del tablado a partir del punto de vista del espectador que ronda estos espacios extradramáticos:

Come atropelladamente el día de fiesta el que piensa gastar en la comedia aquella tarde: el ansia de tener buen lugar le hace no calentar el lugar en la mesa. [...] Pasa adelante nuestro holgón y llega al que da los lugares en los bancos. Pídele uno y el hombre le dice que no hay, pero que le parece que a uno de los que tiene dados no vendrá su dueño, que aguarde a que salgan las guitarras, y que si entonces estuviere vacío se siente. Quedan deste acuerdo, y él por aguardar entretenido, se va al vestuario. Halla en él a las mujeres desnudándose de caseras para vestirse de comediantas (267).

6 Los llamados "mosqueteros" eran hombres que iban a la comedia que se representaba en corrales y coliseos con el objetivo de abuchear la representación y causar desmanes. Parece que realmente eran temidos, tanto por los poetas dramaturgos como por las compañías teatrales.

7 Según la noticia de Enrique Suárez Figaredo, este texto "se publicó en dos partes: El día de fiesta por la mañana... (Madrid, 1654) y El día de fiesta por la tarde... (Madrid, 1659), estampadas en la imprenta de María Quiñones" (146). 
Zavaleta describe también cómo las mujeres toman su lugar en la "cazuela", sitio del corral destinado a ellas para que no se mezclaran con los hombres, y evitar, así, incidentes vergonzosos: "[...] Entran y hállanla salpicada. No toman la delantera, porque ese es el lugar de las que van a ver y ser vistas" (270).

Igualmente, Zavaleta describe la suerte de los comediantes en relación con los ataques de los mosqueteros o la ausencia de público. Aquí aprovecha para dar más información de las entrañas de la actividad teatral: la preparación de los espectáculos por parte de las compañías, los ensayos y el empeño de los comediantes, no sólo por agradar a los espectadores, sino por tratar de ser atacados lo menos posible durante "la comedia", principalmente por los mosqueteros:

Veamos ahora en fee de qué [los mosqueteros] se atreven a hablarles mal los que allí se les atreven en fee del embozo de la bulla. Saben que todo aquel teatro tiene una cara, y con la máscara de la confusión los injurian [a los comediantes]. Ninguno de los que allí les dicen pesadumbres injustamente se las dijera en la calle sin mucho riesgo de que vengasen ellos o de que la justicia los vengase. Fuera de ser sinrazón y cobardía el tratarlos allí mal, es inhumano desagradecimiento, porque los comediantes son la gente que más desea agradar con ser su oficio entre cuantos trabajan en la república. Tanta es la prolijidad con que ensayan una comedia, que es tormento de muchos días ensayarla. El día que la estrenan diera cualquiera de ellos de muy buena gana la comida de un año por parecer bien aquel día. En saliendo al tablado, ¿qué cansancio, qué pérdida rehúsan por hacer con fineza lo que tienen a su cargo. [...] Con tan gran extremo procuran cumplir con las obligaciones de la representación por tener a todos contentos que, estando yo en el vestuario algunos días que había muy poca gente, les oía decirse unos a otros que aquellos son los días de representar con mucho cuidado, por no dar lugar a que la tristeza de la soledad les enflaquezca el aliento, y porque los que están allí no tienen la culpa de que no hayan venido más (268).

Este testimonio es muy interesante porque, a partir de la observación sobre las ventajas del anonimato del espectador, el autor invierte el punto de vista y ubica a los comediantes como espectadores de, metafóricamente, esa máscara colectiva que oculta la identidad individual y que por ello ataca sin empacho a los comediantes. Todo esto habrá influido en los dramaturgos para la generación de resortes dramáticos en el uso de técnicas metateatrales a través de situaciones en las que los espectadores se habrán visto reflejados. Si la estética del barroco español estaba influida por este topos, entonces era considerado seguramente en la composición dramática, y más aún, en la representación. Sobre esto, Diez Borque observa que "aparece la recepción como criterio básico en el afianzamiento y justificación 
de la comedia nueva. Por eso la comedia se construye, lo veremos, como un perfecto mecanismo de recepción, con un diseño calculadísimo" ("Lope de Vega" 41-42).

Por otra parte, el libro de Zavaleta ofrece también testimonios correspondientes a otro tipo de espectador, uno más letrado que los hombres y las mujeres de los que acabamos de hablar. Seguramente tomando en cuenta su propia experiencia en los espectáculos teatrales, este autor considera un tipo de recepción más versado en cultura literaria, crítica y reflexiva en relación con la construcción artística de "la comedia", el deleite estético y la necesidad de educar al espectador, más allá del puro divertimento o de recibir el mensaje de instrucción didáctica:

Ahora bien, quiero enseñar al que oye comedias a oírlas, para que no saque del teatro más culpas de las que llevó. Procure entender muy bien los principios del caso en que la comedia se funda, que con esto empezará desde luego a gustar de la comedia. Vaya mirando si saca con gracia las figuras el poeta, y luego si las maneja con hermosura, que esto hecho bien suele causar gran deleite. Repare en si los versos son bien fabricados, limpios y sentenciosos, que si son desta manera le harán gusto y doctrina, que muchos, por estar mal atentos pierden la doctrina y el gusto. Note si los lances son nuevos y verisímiles, que si lo son hallará en la novedad mucho agrado, y en la verisimilitud le hará grande placer a la mentira con todo el aire de la verdad. Y si en todas estas cosas no encontrare todo lo que busca, encontrará el deleite de acusarlas, que es gran deleite. [...] Esto en cuanto a lo que se puede notar en lo escrito de una comedia (269).

A continuación, Zavaleta alude a los elementos espectaculares de la comedia: el vestuario, gestualidad, decoro, que las acciones coincidan con las palabras, la encarnación de los personajes en general, los bailes:

[...] vamos ahora a lo que se ha de atender en lo representado. Observe nuestro oyente con grande atención la propiedad de los trajes, que hay representantes que en vestir los papeles son muy primorosos [...]. Repare si las acciones son las que piden las palabras, y le servirán de más palabras las acciones. Mire si los que representan ayudan con los ojos lo que dicen, que si lo hacen le llevarán los ojos. No ponga cuidado en los bailes, que será descuidarse mucho consigo mismo. Haga, fuera desto, entretenimiento de ver al vulgo aplaudir disparates y tendrá mucho en qué entretenerse. Gastando desta manera el tiempo que dura una comedia no habrá gastado mal aquel tiempo. Siendo esto así, me holgara yo mucho de que hiciera de aquellos ratos empleo apacible y provechoso (Ibídem). 
Podemos identificar aquí que, detrás de estas recomendaciones, necesariamente se plantea una posición objetiva y razonada de la recepción, lo cual habría implicado una distancia frente al fenómeno teatral, desde el punto de vista de los procesos de identificación en el momento de la representación. Se trata de reflexionar críticamente sobre los procedimientos de construcción para valorarlos. Pero también se trata de ver al espectador menos avisado, al "vulgo", como parte del gran espectáculo social que era la comedia.

Tener en cuenta al receptor como premisa implicaba que la comedia estaba, entonces, construida con una buena cantidad de guiños dirigidos a aquél -piensa Diez Borque-, o sea, con "técnicas para dirigir su atención" ("Lope de Vega" 42). Por su propia naturaleza, el metateatro como tema, como forma o técnica era un estimulante fundamental para la recepción: implicaba el cuestionamiento de la construcción de la realidad (ficticia o "real"), y por ello, el lugar que el espectador ocupaba en ella.

Carmen Hernández Valcárcel considera, por ejemplo, que "hay que convenir en el fuerte vitalismo barroco que pretende implicar al lector o al espectador en la problemática expresada sobre el escenario" ("Algunos aspectos del teatro" 96). Pero, la inmersión del receptor en el teatro áureo dependía también de convenciones genéricas. Al respecto, la misma autora menciona que "la práctica del teatro en el teatro se produce en todos los géneros, pero con diferente tratamiento, derivado de sus peculiares estéticas propias, del público o el medio al que se dirige, de los actores que representan la ficción, etc." (Ibídem).

\section{Conclusiones}

Así pues, si reflexionamos sobre los modos de producción y de recepción metateatral, según los propone García Barrientos, con base en el horizonte de expectativas del teatro barroco español, podemos decir que la producción metateatral tiene dos modos de ser: el dramático, cuyas técnicas son el metateatro, el metadrama y la metadiégesis; así como el especulativo, que corresponde a la tematización de éstos a la luz del tópico del theatrum mundi y que, en un momento dado, puede tomar forma en la estructura del drama.

Por su parte, la recepción metateatral puede reconstruirse con base en los tres niveles dramáticos del teatro dentro del teatro: el extradramático, que corresponde al plano escénico; el intradramático, que corresponde al plano ficticio, y el metadramático, que se refiere al drama dentro del drama, por el cual se movería entre el extradramático y el intradramático, según la técnica metateatral y el efecto que produjera.

Para la composición de su texto, el poeta dramático áureo habría considerado no solamente los aspectos intrínsecamente artísticos a la composición, sino también los relativos a la realización del montaje; esto es, el repertorio de la comedia para seguirlo o matizarlo con 
base en la fórmula lopesca de la Comedia Nueva, según el periodo de producción, y seguir o matizar también el modelo del subgénero elegido (comedia de capa y espada, comedia palaciega, comedia de santos, auto sacramental, tragedia histórica, comedia de comendadores, etcétera). Asimismo, habría considerado a la compañía teatral candidata para la venta y la puesta en escena de su comedia (habría pensado principalmente en los atributos de los comediantes en cuestión), y habría reflexionado en el espacio escénico para la representación (si sería abierto, cerrado, un corral, un salón de palacio, una casa, ambiente rural, ambiente urbano). Finalmente, también habría tomando en cuenta si la comedia era para alguna celebración especial, cortesana o religiosa, o simplemente una comedia de temporada teatral para corral o coliseo.

Todos estos factores de influencia en la composición dramática habrían sido determinantes para que el poeta imaginara cómo se daría la relación entre el espectador y los comediantes en los planos extradramático e intradramático durante la representación, y por tanto para que determinara que uso le convenía hacer de la metateatralidad: si como tema, parte estructurante de la trama o a través de técnicas en escena o situaciones específicas. Así, la comedia presentaba una estética teatral que implicaba fines didácticos, pero muchas veces también rasgos autorreferenciales sobre la práctica teatral, en ocasiones simplemente como recurso de divertimento.

Todo esto respondía, en definitiva, a distintas recepciones, como lo apunta Diez Borque y lo muestran los testimonios presentados. Habría espectadores que sólo iban a divertirse a "la comedia", quienes se implicaban en los vericuetos cotidianos de la representación antes, durante y después de ésta, en los espacios extradramáticos. Habría espectadores que, por su alto nivel socioeconómico y el lugar que ocupaban en los corrales o los coliseos, considerarían al movimiento de los espectadores de estratos sociales bajos y su interacción con los comediantes como parte del espectáculo (y tal vez como la parte más divertida de éste). Habría un tercer tipo de espectador quien -además de interesarse en todo lo anterior y con un sentido más reflexivo y crítico del arte teatral-, prestaría también atención a lo concerniente a la eficacia de la construcción artística de los versos y el espectáculo por parte del poeta dramático, incluyendo la interpretación de los papeles por parte de los comediantes.

Ante este complejo panorama de recepción, tanto el autor de comedias como los comediantes debían pensar en mecanismos que produjeran llamados de atención constantes a los diversos espectadores para lograr mantener su atención y, en la medida de lo posible, una atención más o menos benévola. Estos efectos podían producirse con prolijidad mediante el uso de técnicas y tópicos metateatrales que involucraran, de manera directa y activa, al público, aunque ello supusiera muchas veces arriesgarse a generar reacciones adversas en sectores de espectadores y a que la comedia terminara en situaciones incontrolables. 
Este horizonte de expectativas nos permite identificar, en los textos dramáticos del teatro español barroco, al metateatro como productor de unos efectos de sentido que se relacionaban directamente con la propia actividad teatral en su época y durante la representación. En ciertas ocasiones, la comedia podía estar imitando sucesos en los tres niveles recepcionales: el extradramático, el intradramático y el metadramático, oscilando entre uno y otro.

Así también, podríamos decir que la importancia del metateatro en las comedias habría estado en si se utilizaba sólo como recurso técnico, como tema, o incluso de forma temático-estructural. Ello habría dependido, decíamos, del subgénero en cuestión, pero también del estilo del poeta dramático y de la etapa de composición y representación de la obra, así como del espacio de representación. Como lectores del metateatro, deberemos tener en cuenta tal horizonte y las particularidades de la comedia en cuestión, para percibir y entender un fenómeno de teatralidad que en la actualidad se usa y puede seguir usándose. Se trata de uno de los resortes esenciales para captar la atención de aquel espectador que aún asiste a ver teatro clásico hispánico y que puede ser seducido por esta visión del theatrum mundi -la cual, desde la perspectiva de las nuevas teatralidades, es uno de los referentes de la realidad que tanto el arte escénico clásico como el contemporáneo, muchas veces evocan y representan.

Lo interesante para el seguimiento de esta investigación será pasar de la recepción del "sujeto psicoanalítico, percibiente y cognitivo" a la recepción del "sujeto sociológico, colectivo y empírico", para contrastar lo aquí expuesto e indagar cómo se producen los efectos de la metateatralidad en el espectador (desde dónde y cómo los percibe, qué le significan a partir de un corpus dramático). En particular, a partir de este corpus del teatro clásico hispánico, donde dichos efectos pudieran considerarse con mayor énfasis en el desarrollo del montaje y como una más de las estrategias para su actualización. Podremos corroborar, así, en qué porcentaje nuestra propuesta se refleja patentemente durante el acto de la representación escénica, para de ahí generar postulados metodológicos que, en un momento dado, puedan ser de utilidad para el análisis de los espectáculos teatrales.

\section{Fuentes consultadas}

Abel, Lionel. Metatheatre: A New View of Dramatic Form. New York: Hill and Wang, 1963. Bobes Naves, María del Carmen. Semiología de la obra dramática. 2a ed. Madrid: Arco Libros, 1997.

Diéguez, Ileana. "Escenarios y teatralidades liminales. Prácticas artísticas y socioestéticas”. Archivo Virtual de Artes Escénicas, ARTEA, Universidad de Castilla-La 
Mancha, 2009, artesescenicas.uclm.es/index.php?sec=texto, consultado el 15 de octubre de 2018.

Diez Borque, José María. Literatura (novela, poesía, teatro) en bibliotecas particulares del Siglo de Oro español: 1600-1650. Madrid: Iberoamericana-Vervuert, 2010.

Diez Borque, José María. “Teatro español del siglo xviı: pluralidad de espacios, pluralidad de recepciones". El teatro del Siglo de Oro ante los espacios de la crítica. Encuentros y revisiones. Editado por Enrique García Santo Tomás. Madrid: Vervuert, 2002, pp. 139-172.

Diez Borque, José María. "Lope de Vega y los gustos del vulgo". Teatro: revista de estudios teatrales, núm. 1, 1992, pp. 7-32.

Fischer-Lichte, Erika. Estética de lo performativo. Introducción de Óscar Cornago. Traducido por Diana González Martín y David Martínez Perucha. Madrid: Abada Editores, 2004.

Fischer-Lichte, Erika. Semiótica del teatro. Traducido por Elisa Briega Villarubia. Madrid: Arco Libros, 1999.

García Barrientos, José Luis. Cómo se comenta una obra de teatro. Ensayo de método. $2^{\mathrm{a}}$ ed. Madrid: Síntesis, 2007.

García Gutiérrez, Juan. "Dos aspectos de la cosmovisión barroca: la vida como sueño y el mundo como teatro". Revista de Estudios Extremeños, vol. 58, núm. 3, 2002, pp. 863-876.

Hernández Valcárcel, Carmen. "Algunos aspectos del teatro dentro del teatro en Lope de Vega”. Anales de Filología Hispánica, núm. 4, 1988-1989, pp. 75-96.

Hesse, José. Vida teatral en el Siglo de Oro. Madrid: Taurus, 1965.

Hornby, Richard. Drama, Metadrama and Perception. Lewisburg: Bucknell University Press, 1986.

Iser, Wolfgang. "El proceso de lectura”. Textos de teorías y críticas literarias (Del formalismo a los estudios poscoloniales), editado por Nara Araújo y Teresa Delgado. Ciudad de México: Universidad Autónoma Metropolitana-Iztapalapa/Universidad de la Habana, 2003, pp. 485-513.

Larson, Catherine. "El metateatro, la comedia y la crítica: hacia una nueva interpretación". Actas del X Congreso de la Asociación Internacional de Hispanistas, editado por Antonio Vilanova. Barcelona: Asociación Internacional de Hispanistas, 1992, pp. 1013-1020.

Leñero, Carmen. Del faro al foro: la imaginación novelesca frente a la imaginación teatral. Ciudad de México: Instituto de Investigaciones Filológicas-unam, 2016.

Leñero, Carmen. La escritura invisible. Teatralidad en textos filosóficos y literarios. Ciudad de México: Instituto de Investigaciones Filológicas-UnAM/CONACUlTA, 2010. 
Maestro, Jesús G. "Cervantes y Shakespeare: el nacimiento de la literatura metateatral". Bulletin of Spanish Studies. Essays in memory of E. C. Riley on the Quartercentenary of Don Quixote, editado por Jeremy Robbins y Edwin Williamson, vol. 81, núms. 4-5, 2004, pp. 599-611.

Maravall, José Antonio. La cultura del barroco. Madrid: Ariel, 1975.

O'Connor, Thomas Austin. "Is the Spanish Comedia a Metatheater?" Hispanic Review, vol. 43, núm 3, 1975, pp. 275-291.

Orozco, Emilio. El teatro y la teatralidad del barroco. Barcelona: Planeta, 1969.

Pavis, Patrice. Análisis de los espectáculos. Teatro, mimo, danza-teatro, cine. Traducido por Jaime Arrambide. Buenos Aires: Paidós, 2017.

Orozco, Emilio. Diccionario de la performance y del teatro contemporáneo. Traducido por Magaly Muguercia. Nuevo León: Universidad Autónoma de Nuevo León, 2014.

Orozco, Emilio. "Tesis para el análisis del texto dramático". Traducido por Isabel Martín. Gestos: teoría y práctica del teatro hispánico, núm. 33, 2002, pp. 9-34.

Pedraza, Felipe B. "Obra dramática". Lope de Vega. Vida y literatura. Salamanca: Olmedo Clásico/Gráficas Varona, 2008, pp. 109-185.

Von der Walde, Lilian. "La recepción: diversas proposiciones". Revista Casa del Tiempo, junio de 2004, pp. 2-12.

Zavaleta, Juan. "El día de fiesta en Madrid y sucesos que en él pasan". Lemir, revista de Literatura Española Medieval y del Renacimiento. Editado por Enrique Suárez Figaredo, núm. 20, 2016, pp. 145-344. 


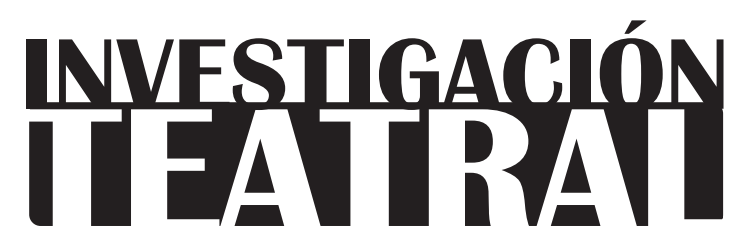

Revista de artes escénicas y performatividad

Vol. 10, Núm. 15

abril-septiembre 2019

Segunda época

ISSN impreso: 1665-8728

ISSN electrónico: 2594-0953

Universidad Veracruzana

\title{
¿Cómo será la muerte, ese cesar de sentir? (En torno a Bodas de sangre, de Antonio Gades)
}

\author{
Nidia Vincent*
}

\footnotetext{
* Facultad de Letras Españolas, Universidad Veracruzana, México e-mail:nidiadragon@gmail.com
} 


\title{
¿Cómo será la muerte, ese cesar de sentir? (En torno a Bodas de sangre, de Antonio Gades)
}

\section{Resumen}

La presente investigación se ocupa del ballet de Antonio Gades titulado: Crónica del suceso de bodas de sangre, una manifestación de danza-teatro que fue dirigida por Carlos Saura y Antonio Gades (a partir de un libreto de Alfredo Mañas basado en el drama de Federico García Lorca), y estrenada por la compañía Antonio Gades en el Teatro Olimpia de Roma, en 1974. Dicha obra se estudia con base en el registro fílmico de Carlos Saura. Se comparan los lenguajes lingüístico y corporal, aunque poniendo énfasis en los alcances poéticos de representación de este último, y entendiendo a la teatralidad desde una perspectiva teórica más amplia a partir de la propuesta de Jorge Dubatti.

Palabras clave: danza-teatro, flamenco, Federico García Lorca, poiesis, liminalidad.

\section{What would Dead, that Cessation of Feeling, be like? A Reflection on Bodas de sangre, by Antonio Gades}

\begin{abstract}
This article examines the dance-theater piece Crónica del suceso de Bodas de sangre, by Antonio Gades, using Carlos Saura's film as a register. A comparison of the language of the word and that of the body is attempted emphasizing the latter's poetic representational abilities, and approaching theatricality from a wider theoretical perspective, after Jorge Dubatti's proposal.
\end{abstract}

Keywords: dance-theater, Flamenco, Federico Garcia Lorca, poiesis, liminality. 


\section{¿Cómo será la muerte, ese cesar de sentir? (En torno a Bodas de sangre, de Antonio Gades)}

$\mathrm{E}$ 125 de julio de 1928 apareció en el periódico español $A B C$ la noticia del asesinato de un joven a manos de un enmascarado. Poco después, los extraños sucesos fueron esclarecidos: a unas horas de celebrarse el matrimonio entre Francisca Cañada Morales -llamada Paquita "la Coja"- y Casimiro Pérez Morales, la novia huyó por la madrugada con su primo Paco Montes. En el camino fueron emboscados por la hermana y el cuñado de Francisca. Paco murió a consecuencia de varios disparos; la novia escapó de ser estrangulada, fingiéndose muerta.

Una vez desvanecido el misterio, la noticia no tiene en realidad nada de excepcional: son sólo las víctimas de un crimen pasional más. Los sobrevivientes de aquel fatídico día continuaron con sus vidas anónimas. Casimiro Pérez se casó y se mudó a un pueblo cercano. Francisca Cañada, quien falleció de 84 años en 1987, vivió en soledad y retiro, marcada por los hechos sangrientos.

A este suceso se le conoce como el "crimen de Níjar" (pequeña población de Almería, provincia de Andalucía) y ha sido recreado en varias ocasiones. Muy cercano a los hechos, circuló un romance popular; en 1931, Carmen de Burgos ("Colombine") escribió la novela Puñal de claveles; un año después, Federico García Lorca terminó su drama Bodas de sangre, el cual fue estrenado poco después en Madrid; Carlos Arce publicó el estudio El crimen de Nijar. El origen de Bodas de sangre en 1998; Lola Guerrero dirigió en 2005 el documental El crimen de una novia. A estas obras se añade una secuela considerable de trabajos inspirados en la obra teatral de García Lorca.

Las pasiones y la fatalidad de este triángulo amoroso, tan real, tan común, fueron los detonantes para que algunos creadores recuperaran la anécdota desde registros particula- 
res: narrativos, fílmicos o líricos; como ficción o investigación documental; como tragedia o melodrama. De todas estas obras, la de Lorca ha sido la de mayor trascendencia, con una hondura definitivamente trágica que remite a absolutos como la existencia, la verdad, el eros, la identidad, el honor, la muerte. Testimonios de varios amigos cercanos al autor afirman que la noticia despertó su interés desde el primer momento y que el drama fue el resultado de un proceso de lenta gestación. ${ }^{1}$

Bodas de sangre, como la mayoría de las obras teatrales de Lorca, ha sido objeto de incontables montajes, en muchos idiomas y desde propuestas estéticas muy distintas. Uno de los ejemplos más singulares de su universalidad es la puesta en escena del Laboratorio de Teatro Campesino e Indígena, estrenada en Oxolotán (Tabasco, México) a las faldas de un cerro en 1983, con la participación de 180 campesinos. Esa versión libre se alejó -según reseñas del momento- de la poesía lorquiana, pero rescató la fuerza primitiva y básica que anima la historia. Casos distintos son las películas de Carlos Saura -a partir de un ballet de Antonio Gades-, y La novia (2015) de Paula Ortiz. La película de Ortiz optó por un tratamiento preciosista y por apegarse a los parlamentos originales; el ballet de Gades carece de diálogos y apuesta por la expresión corporal. Es este último el objeto del presente artículo.

\section{Crónica del suceso de bodas de sangre de Antonio Gades}

Crónica del suceso de bodas de sangre ${ }^{2}$-título original con que Gades la estrenó en Roma en 1974- es una coreografía apegada a un argumento y con marcadísimos rasgos de dramatización. Es, en sentido estricto, una paráfrasis, en tanto que imita un discurso original apelando a un lenguaje diferente. Así, desde lo corporal, espacial y musical, propone una obra artística autónoma que va más allá de la imitación, pues fue transmutada en un nuevo discurso.

Tanto el espectáculo teatral como la danza son artes de performance, hechos indisolublemente anclados a la efímera ejecución del actor o el bailarín. Esta situación fue un impedimento insalvable para la repetición, conservación y análisis de cientos de manifestaciones artísticas y culturales hasta la aparición del cine. Por ello, más allá de si un video puede

1 Así lo comentan su hermano Francisco García Lorca (ver Federico y su mundo. Madrid: Alianza, 1980, p. 320) y la biógrafa Michelle Auclair (Vida y muerte de Federico García Lorca. Ciudad de México: Era, p. 265), entre otros.

2 Además de la participación de Antonio Gades en el papel de Leonardo (el amante con quien huye la Novia en el drama lorquiano), los protagónicos estuvieron a cargo de Juan Antonio Jiménez, como el Novio, y la primera bailarina Cristina Hoyos, como la Novia. Treinta y cinco años después, la Compañía Antonio Gades reestrenó esta obra. 
capturar y transmitir, o no, el efecto estético que impone sobre el espectador la energía de un ser vivo en escena, resulta invaluable el aporte que los medios audiovisuales han brindado a la historia y estudio de la danza, el teatro y otros espectáculos. Caso muy concreto y especial es el del ballet flamenco Bodas de sangre que, gracias a la película de Carlos Saura, ha llegado a un público amplísimo, trascendiendo generaciones y entusiasmando a todo tipo de espectadores. También ha sido objeto de incontables artículos.

Cuando en 1981, Saura asistió a un ensayo de la compañía de Gades de la reposición de la obra en Madrid, decidió filmarla. Además de ser un conocedor del mundo flamenco, Saura había sido fotógrafo de ballet, lo que le permitió advertir que se encontraba ante un trabajo excepcional del que debía dejarse un registro perdurable.

De modo que el cineasta se dispuso a capturar, a través del séptimo arte, la magia del baile: fijó en una cinta memorable la momentánea belleza del cuerpo humano en movimiento; mas no se limitó a grabar una función ni optó por una adaptación cinematográfica del ballet, sino que filmó un ensayo. Como la breve duración de éste no alcanzaba los sesenta minutos mínimos que se exigen para un largometraje, Saura decidió incluir algunas secuencias a modo de introducción, en las que observamos lo que antecede a la ejecución en camerinos y en el salón de ensayos. De este modo, la película también documenta el proceso de todos los participantes y sumerge a los espectadores en el "rito" que habrá de acontecer.

Saura y el fotógrafo Teodoro Escamilla no privilegiaron el plano general -obligado en las grabaciones de danza - sino que dirigieron su atención a gestos, miradas, brazos, piernas, pies, como piezas artísticas, ofreciendo su propio punto de vista del espectáculo. La excepcional factura de esta "película-ballet" despertó gran interés y convidó a Saura a continuar con este género híbrido con filmes como Carmen (1983), Amor brujo (1986), Sevillanas (1991), Flamenco (1995), Tango (1998) y Salomé (2002).

Bodas de sangre de Carlos Saura no es la "grabación de una función de la compañía de Gades", sino una propuesta de lectura, de interpretación, un volver a relatar desde el lenguaje cinematográfico, con la firma al calce de un director que propone su propia estética y nos invita a revivir un arte fugaz.

Como dije previamente, el presente trabajo se centrará en la propuesta de Gades (aunque se tenga que partir necesariamente de un objeto de estudio mediado por una cámara), influido por la visión de un cineasta que "organiza nuestra mirada". Cabe también apuntar que la adaptación del argumento estuvo a cargo del dramaturgo Alfredo Mañas -quien

3 Para Dubatti, el cine, en tanto mediador entre un espectáculo en vivo y un espectador, anula una experiencia directa (convivio) e implica una relación determinada por lo tecnológico (tecnovivio). El cine, como el teatro, organiza la mirada de los otros y produce una óptica política (“Convivio y tecnovivio”). 
INVESTIGACIÓNTEATRAL

Revista de artes escénicas y performatividad

Vol. 10, Núm. 15

abril-septiembre 2019
¿Cómo será la muerte, ese cesar de sentir?

(En torno a Bodas de sangre, de Antonio Gades)

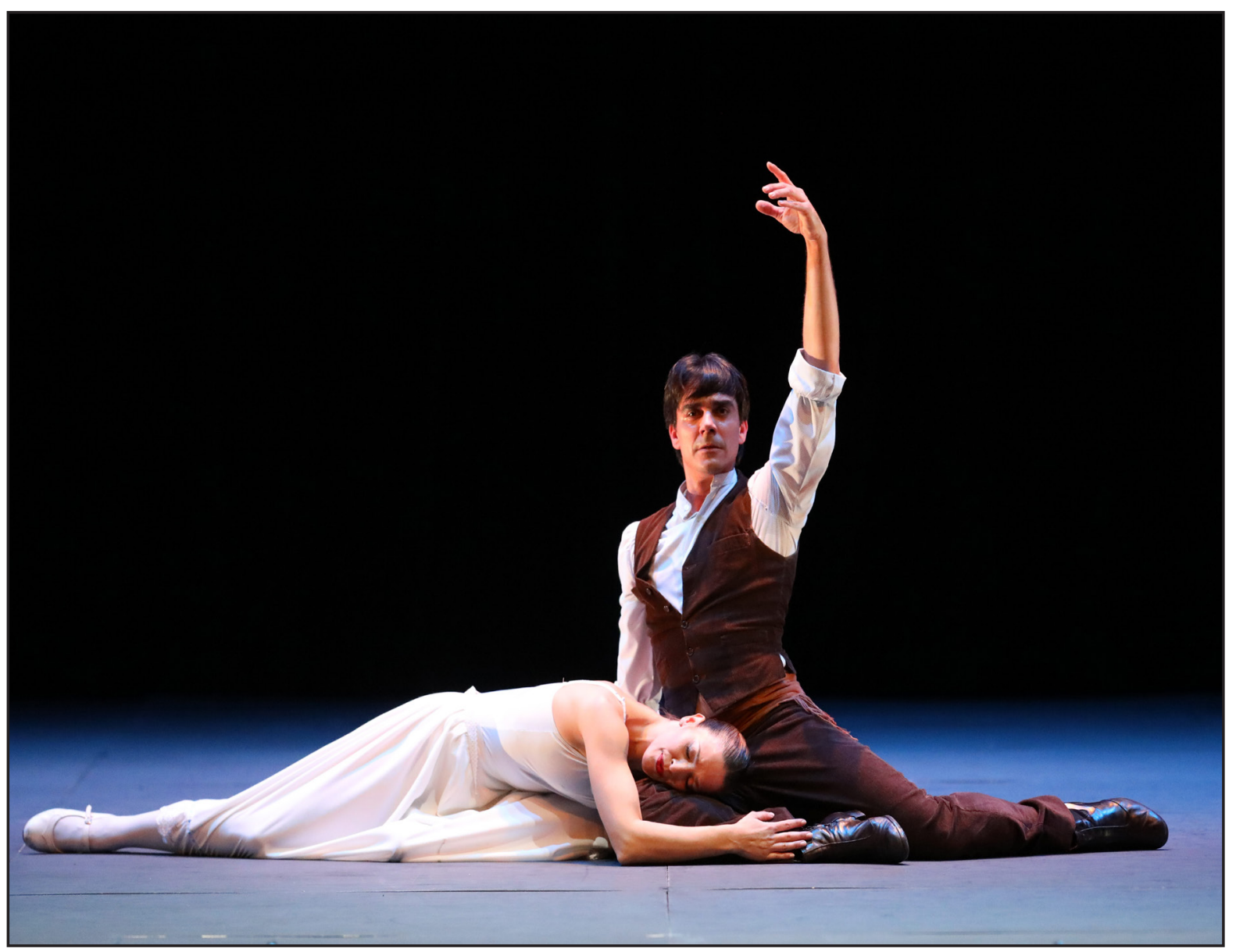

Bodas de sangre (c) Stanislav Levshin | Fundación Antonio Gades

anteriormente había escrito una versión del Don Juan (1965) para Gades-. Mañas redujo la obra a seis escenas, eliminó tres cuadros ${ }^{4}$ y personajes secundarios. Posteriormente, siguieron las coreografías que nacieron directamente de libreto y, cosa inusual, la composición musical se hizo ex profeso para la coreografía (Domínguez et al 18). Si bien Gades preservó la esencia de la obra lorquiana, su creación no es de una fidelidad ciega sometida al texto dramático, sino que éste sirvió de inspiración, de provocación para el coreógrafo.

4 La obra de teatro consta de tres actos, distribuidos en siete cuadros. El ballet eliminó el cuadro 3 del Acto I (visita del Novio y la Madre a la casa de la novia para llevarle los regalos) y los cuadros 1 y 2 del Acto III (aparición de la Mendiga y la Luna). 
La trama original de la obra de Lorca versa sobre la tragedia de un amor prohibido y la historia de muerte y venganza entre dos familias rivales. Descendientes de estas familias son Leonardo y el Novio, ambos enamorados de la misma mujer. A pesar de que Leonardo es un hombre casado y tiene un hijo, y la Novia acepta casarse con otro para mejorar la situación precaria de su familia, la pasión que los uniera pervive y lleva a los amantes a huir en plena fiesta de bodas. El Novio, burlado, sale tras ellos en compañía de varios hombres del pueblo. La Luna y una Mendiga presagian algo funesto. Los dos rivales mueren en un duelo. Las mujeres de ambas familias quedan solas y hundidas en el desconsuelo.

La línea argumental de la danza-teatro de Gades mantiene ambos motivos: el amor imposible abrasado por la fuerza de la atracción erótica y las interminables rencillas entre familias antagónicas. La adaptación conserva las temáticas de los celos y el amor maternal, pero deja fuera las diferencias económicas entre los cónyuges y las conveniencias que conlleva su unión. Los parlamentos fueron eliminados por completo, ${ }^{5}$ siendo el gran mérito de Gades el haber trasladado la intensidad del drama a danza y gestos, a la guitarra y canto flamencos, esa mezcla cultural andaluza en donde el toque, el baile y el cante se dan cita para expresar el sentimiento.

Ver una obra de García Lorca adaptada al baile flamenco no genera extrañeza. Por el contrario, resulta una traslación natural dado el temperamento y temáticas de muchos de los textos de este autor, además de que se trata de una manifestación hispana con claros vasos comunicantes con la estética de varios miembros de la Generación del 27 relacionados al Neopopulismo (como fue el caso de José Bergamín, Rafael Alberti, Gerardo Diego, Manuel Altolaguirre, Emilio Prados y el mismo García Lorca). Este último fue el más flamenco de este grupo de poetas cultos, como hizo patente en sus volúmenes "Importancia histórica y artística del canto primitivo andaluz llamado 'cante jondo"' (1922), "Arquitectura del cante jondo" (La Habana, 1930) "Juego y teoría del duende" (Buenos Aires, 1933) y sus poemarios: Poema del cante jondo (1931) y El romancero gitano (1924-1927).

El papel que el compositor Manuel de Falla y Federico García Lorca jugaron para la expansión y revaloración del arte gitano andaluz es innegable. Si bien hay errores e imprecisiones en los artículos de Lorca -dado que no son el resultado de investigaciones rigurosas-, su importancia reside en haber captado la desgarradora y auténtica vena popular del flamenco. En opinión de Daniel Pineda:

Federico no fue un erudito en el tema; fue -lo hemos dicho- un exegeta; un cantor lírico, un intérprete del dramatismo de "lo flamenco". Pero tenía una genialidad innata

5 Sólo se mantienen del texto de Lorca la alboreá "Despierte la novia” y una nana, cuya letra es un presagio funesto. 
y un oído fino, agudo, para captar la música. No olvidemos que era un notable pianista y sabía, incluso, tocar la guitarra. Y de Falla, su gran maestro, aprendió todo lo que se sabía, hasta 1922, sobre esta temática (175).

Resulta pertinente hacer un paralelismo entre esta revaloración emprendida por Lorca y de Falla -cuando el gobierno republicano dio su apoyo incondicional a la música con reformas en la enseñanza, formación de orquestas y difusión de las manifestaciones musicales populares-, y la labor que Antonio Gades y otros entusiastas emprendieron, en pleno franquismo, ${ }^{6}$ para resignificar el flamenco y sustraerlo del folclorismo simple al que el régimen lo había suscrito, reduciéndolo a un artículo para turistas. Así como Manuel de Falla concertó en sus composiciones lo clásico y lo andaluz, Gades, ${ }^{7}$ con su personal estilo, reunió la técnica del ballet clásico con la espontaneidad y pasión de lo popular, y se convirtió en un referente para mucho de lo que habría de acontecer desde entonces en la historia subsecuente de este baile.

\section{Ballet-flamenco o danza-teatro}

Bodas de sangre de Gades corresponde indudablemente al género conocido como ballet-flamenco; no obstante, cabe ampliar esta perspectiva al concebirlo como ballet dramático o danza-teatro. ¿Y por qué no? Finalmente, lo que importa para la presente investigación es acercarse a este género de manifestaciones, caracterizadas por sus formas híbridas y liminares, a partir de las teorías del investigador argentino Jorge Dubatti, quien reconoce en el teatro tanto su tradicional naturaleza dramática, como una no-dramática, y plantea verlo como una "zona compartida de intercambio o combinación" ("Teatro-matriz y teatro liminal" 86).

La obra de Gades que nos ocupa es un ballet-flamenco, entendiendo como ballet una danza apegada a un argumento, y como flamenco, una escuela o estilo específico de música y baile andaluces. Puede decirse que el ballet-flamenco, ese nuevo formato que salió de los

6 Gades fue hijo de un republicano y él mismo fue antifranquista y un socialista convencido. Un dato interesante que refleja su postura política es que, a pesar del éxito que estaba teniendo en París Crónica de un suceso: Bodas de sangre, Gades disolvió la compañía y se retiró de la escena en un acto de protesta por los últimos fusilamientos del franquismo en septiembre de 1975.

7 De importancia semejante a la que previamente tuvo el bailarín, coreógrafo y teórico Vicente Escudero (1888-1980), quien estableció normas para el baile flamenco, lo revolucionó y se interesó por transmitirlo. Él apadrinó a Antonio Gades. 
cafés cantantes para pasar a los teatros, tiene sus antecedentes -así como la danza-teatro alemana los tuvo en la vanguardia expresionista de las primeras décadas del siglo $\mathrm{xx}$ - en dos legendarios estrenos: El amor brujo, en 1915, en Madrid, del compositor Manuel de Falla, a partir del libreto de María de la O Lejárraga, ${ }^{8}$ y El sombrero de tres picos, en 1919, por la compañía de Serguéi Diaghilev y la participación de Picasso en el diseño de escenografías y vestuarios.

Esos novedosos espectáculos flamencos, pensados para espacios más amplios, se apegaban a una línea argumental acompañada de composiciones musicales más elaboradas que las melodías populares, que podían incluir o no al cantaor y la guitarra, y que sumaron, al igual que la ópera o el ballet clásico, escenografía, vestuario y luces. El baile flamenco, caracterizado por su libertad de improvisar y no verse limitado a una coreografía o un tema específicos, perdió su natural espontaneidad, pero se fortaleció como "un baile colectivo, sistematizado y más academicista" (Brao 53). Sin embargo, no fue sino hasta la década de los setenta, después de su largo tránsito por los tablaos, que resurgió un baile flamenco teatral, cuyos representantes -entre ellos Gades $-{ }^{9}$ incursionaron en una nueva estética que sumó la expresión corporal y actoral al dominio de la técnica dancística, dio mayor peso a la dramaturgia y utilizó escenografías simples para los fondos, e iluminación muy sobria. A pesar del escaso número de producciones en este formato, fueron un parteaguas indudable para el baile flamenco de la época (78).

Ahora bien, el término "danza-teatro" suele remitir a la propuesta surgida en Alemania, con las coreografías de Pina Bausch ${ }^{10}$ en la década de los setenta. Bausch rompió con las formas estético-expresivas imperantes, sustituyendo el entablado clásico por superficies simples, integrando a su compañía a bailarines que no cumplían con el ideal de belleza clásica e incluyendo movimientos cotidianos, toscos, por completo ajenos a la danza clásica. Un sello particular de sus coreografías fue la inclusión de una especie de "relato" sin tiempo y espacio definidos, que se desarrollaba en episodios organizados en una estructura no lineal, a partir de acciones escénicas simultáneas o fragmentadas a modo de collage. Los espectáculos de Bausch dejan -incluso en grabaciones- un vivo impacto en el espectador, quien ya no sólo admira y disfruta el dominio de la técnica, sino que se ve enfrentado a una obra que produce "sentido". Un sentido que despierta curiosidad, invita a ser interpretado y conduce a un horizonte de emociones más amplio.

8 El libreto fue atribuido a Gregorio Martínez Sierra, pero de acuerdo con investigaciones recientes fue escrita por su esposa, María de la O Lejárraga.

9 José Granero, Mario Maya, Manuela Vargas, Curro Vélez, José Camborio, entre otros.

10 Pina Bausch (1940-2009) fue directora de la compañía Tanz-theater de Wuppertal, desde 1972 hasta su muerte. 
Si bien todos estos rasgos son los que caracterizan a la escuela de Bausch, nada impide extender el uso del término danza-teatro, y recuperar el sentido original del binomio que lo conforma y que desde su nombre lleva implícita la constante disputa del arte de la danza, esto es: la oscilación entre su autonomía o sujeción frente a una tradición mimética que le exigiría ser una "representación". Como lo explica la investigadora y coreógrafa argentina Beatriz Lábatte:

[...] la tensión entre estos dos extremos, entre el placer de hacer y la necesidad de decir, entre la fuerte presencia de la materialidad real del cuerpo, del espacio y de la dinámica del movimiento y lo que esto material viene a sustituir, lo que viene a 'representar', va a signar toda la historia de la danza del espectáculo occidental, desde aquella primera manifestación, allá por los finales del siglo XvI, ${ }^{11}$ hasta hoy. Inclinando la balanza en un sentido o en otro según los períodos y según los diferentes creadores (12).

Este tipo de relación, a veces natural, incluyente y de mutuo enriquecimiento; otras, de ruptura y radicalismo, puede también trasladarse a las controversias entre texto literario (palabra) versus espectáculo y corporalidad del actor, que tanto ha ocupado a creadores y teóricos del teatro del siglo xx y xxi. Hoy, por ejemplo, el "teatro del cuerpo" o "teatro físico" pone énfasis en la técnica y el control del actor sobre sus instrumentos básicos (voz, rostro y cuerpo), dejando en segundo término el argumento. Para esta corriente, el auténtico lenguaje teatral es pantomima, danza, circo, ruidos, y el actor debe formarse como un acróbata, un bailarín, un cantante, un gimnasta, pues sus movimientos y voz (o ruidos) serán signos capaces de producir efectos catárticos en el receptor.

Esta postura es heredera de varias tendencias del siglo $\mathrm{xx}$ que experimentaron alejándose de la anécdota, de la representación de la realidad, incluso de la lógica verbal, para centrarse en la energía corporal, la voz en sí, más allá de un lenguaje transmisor de sentido verbal. Directores esenciales del siglo xx dieron un papel preponderante a la corporalidad (J. Copeau, Meyerhold, Artaud, Grotowski, Decroux, Brook, Barba). Antonin Artaud, desde los años treinta, objetó la centralidad del diálogo para buscar una poesía espacial y corporal; un estado anterior al lenguaje, mediante signos, "jeroglíficos animados" generados por los gestos, actitudes y ruidos de los actores, que pudieran revelar un sentido liberado de la atadura de las palabras (60). Este distanciamiento del texto literario ha llevado a replantearse el concepto de "teatralidad" con márgenes más amplios y flexibles.

Aquí, Lábatte se refiere a los ballets de corte del renacimiento italiano, organizados por Catalina de Medici: Le Paradis d' Amour, Ballet de Polonais y, el más importante, Ballet Comique de la Reine (1581). 
Respecto a este último punto, resulta pertinente la propuesta Jorge Dubatti, quien ha replanteado la naturaleza de la teatralidad desde América Latina, proponiendo categorías y rasgos que amplían la concepción tradicional del término.

Dubatti $^{12}$ extiende los límites del concepto de teatro a todo aquello que sea un convivio teatral, es decir, una relación dialéctica de las presencias de los cuerpos, de personas que asisten, se reúnen, coinciden en un territorio, miran, aceptando el reconocimiento del otro y de uno mismo en un encuentro que no los deja indiferentes (ver "Convivio y tecnovivio"). Concibe al teatro asociado a una matriz de tres variantes: 1. el acontecimiento teatral, caracterizado por la imprescindible presencia y relación de los cuerpos, sin ningún tipo de intermediario; 2. el lenguaje poético, instancia en donde la materialidad de los cuerpos se desvía de su sentido natural para asumir otro distinto al real, de carácter poético; y 3. la expectación, esto es, la participación del espectador (ver "Teatro-matriz y teatro liminal”).

Salta a la vista que a Dubatti lo anima la intención de problematizar para dilatar, emancipar, el concepto de lo teatral. Bajo esta perspectiva inclusiva, es posible acercarse a la danza-teatro como a una manifestación de la teatralidad (más allá de la escuela de Bausch). Y ver, en el caso de Bodas de sangre de Gades, una manifestación poética y liminar ${ }^{13}$ acorde con las ideas de Dubatti:

[...] si el drama absoluto propone un teatro centrado eminentemente en la palabra, el teatro liminal pone el acento en la ausencia de palabra, en el cruce de la palabra con el movimiento, la música, la plástica, los objetos, con otras disciplinas. Ejemplos: el teatro-danza, el teatro musical, la titiritesca, el teatro físico, el happening, la instalación, teatro del relato, magia, teatro de las artes audiovisuales [...] (“Teatro-matriz" 91).

Crónica del suceso de bodas de sangre fue (y sigue siendo en cada nueva representación $)^{14}$ un convivio teatral en el que se dan cita los espectadores y el cuerpo de los bailarines sin la

12 Dubatti parte de tres nociones teóricas, que no serán tratadas en este trabajo, pero que es necesario mencionar como los ejes de su teoría: "liminalidad", "teatro-matriz" y "organización de la mirada" (ver “Teatro-matriz y teatro liminal”).

13 "No hay teatro sin liminalidad. Llamamos liminalidad a la tensión de campos ontológicos diversos en el acontecimiento teatral: arte/vida; ficción/no-ficción; cuerpo natural/cuerpo poético (en todos los niveles de ese contraste: enunciado/enunciación, constructo poético/construcción poética); representación/ no-representación; presencia/ausencia; teatro/otras artes; teatralidad social/teatralidad poética; convivio/tecnovivio, etcétera. En su plano más abarcador, dramático/no-dramático" ("Teatro matriz" 87).

14 Esta coreografía forma parte del repertorio regular de la Compañía Antonio Gades y se presenta junto con la Suite Flamenca. En noviembre de 2018 fue representada en San Petersburgo. 
intermediación de una cámara, y la presencia física y acciones de estos artistas se desvían de su sentido cotidiano para provocar asombro, extrañeza, contemplación, posiblemente placer. Sobre el carácter poético del convivio teatral de este ballet-flamenco se hablará a continuación, siguiendo a Dubatti.

\section{Estilo del montaje: sobriedad y realismo}

Por otra parte, es muy importante señalar que el montaje que nos atañe se distanció del flamenco tradicional, folclórico, colorido, espontáneo y popular. La estética de este ballet se caracteriza por la sobriedad y un minimalismo que remite a una conceptualización elaborada, culta y moderna, propia de la década de los setenta, como es el caso también de la danza-teatro de Bausch.

En Crónica del suceso... los vestuarios son básicamente en blanco y negro, se utiliza una reducida utilería de mano y la escenografía es mínima (apenas tres sillas para los guitarristas, tres ventanales grandes y la presencia del amplio espejo y el piano, característicos de un salón de ensayos). El atavío de este austero diseño está en el ritmo, los desplazamientos y la música: guitarra flamenca, una alboreá, una seguiriya, un pasodoble, una rumba y una emotiva nana. Gades era de la idea de que con la madurez, el trabajo artístico va prescindiendo de los elementos decorativos, por eso su estilo es más mesurado, tanto en los pasos como en el movimiento de brazos y manos, que el flamenco de tradición popular. Para José Luis Navarro y Eulalia Pablo, el estilo de Gades era "contenido, elegante y radicalmente varonil. Un baile depurado y perfeccionista, con movimientos arrogantes, estilizados y geométricos" (citado en Brao 81).

Llama la atención que, a pesar de la libertad que puede permitir la danza para representar personajes fantásticos o alegóricos, se excluyeron todos los que tenían carga simbólica que aparecen en la obra original (como son la Luna, la Mendiga y la Niña), lo que dio como resultado una pieza estilizada pero de un realismo impactante, apenas aliñado con un mínimo de objetos simbólicos (como son la navaja, el caballo, los azahares, el fajín, la sangre, el río). Con todo, haber optado por el realismo es un acierto de la adaptación, en virtud de que esta obra pertenece a la llamada "trilogía de la tierra española", donde García Lorca, tras su incursión en el surrealismo con Así que pasen cinco años y El público, optó por la corriente realista, quizá por ser el momento de su compromiso con el teatro itinerante de La Barraca y los ideales de la Segunda República.

Resulta especialmente interesante que la coreografía utiliza el procedimiento de mise en abyme, teatro dentro del teatro, cuando el Novio y la Madre interpretan para sí la boda que está por celebrarse, o cuando se incluye el baile de la celebración de la boda en la co- 
reografía. Otro recurso empleado, en este caso propio del cine, es aquel en que los bailarines se congregan y posan para que se tome la fotografía de la boda, y al mismo tiempo simulan -como en un cuadro congelado- la imagen estática capturada por la cámara como testimonio de ese momento.

\section{El lenguaje del cuerpo}

Antes de proseguir, conviene recordar que Bodas de sangre, el ballet, está apegado a un argumento. Los bailarines encarnan a personajes concretos e interpretan acciones específicas que dan cuenta de una historia, de modo que esa larga convivencia entre baile y teatro, "entre el placer de hacer y la necesidad de decir" -como lo describe Lábatte- se dan una nueva cita en esta coreografía, concediendo un lugar preponderante al original lorquiano.

Es obvio que siempre será un problema la correspondencia entre baile y escritura, pero como afirman Isabel Naverón y Amparo Écija en "Leer, bailar, escribir": "En cualquiera de los casos, escribir o bailar, es trazar una historia posible, hacerse consciente de ella, interrogarla" (párr. 4). De modo que para dar su justo valor a las Bodas de sangre de Gades, es preciso detenerse en lo que la danza narró y sus estrategias para hacerlo.

Al bailaor de flamenco se le prepara en las técnicas específicas de este baile y se le lleva a buscar un lenguaje corporal propio. Este lenguaje, pre-verbal, extra-verbal y paralingüístico, traduce y transmite información objetiva y situaciones emocionales a través de la corporalidad con un énfasis muy particular en el movimiento de manos, la gestualidad y el taconeo que, además de ajustarse a una técnica y buscar el virtuosismo, son altamente expresivos y significativos.

En el caso concreto de la Compañía de Gades destaca una técnica impecable, sobria, moderna y la predominancia de lo "representativo", dado que es una coreografía en donde los bailarines "actúan" apegados a un argumento y son pocos los pasajes en que el baile se aleja de contar. Pero centrémonos en algunos detalles para revisar cómo, desde el lenguaje de la danza y a través de la mediación de la cámara, llegan a nosotros estos sucesos y su intención poética. ${ }^{15}$

15 La focalización de la cámara y la edición determinarán, por supuesto, nuestra recepción, la cual no sería la misma si estuviésemos frente al espectáculo en vivo. Por ejemplo, una toma desde el cenit del escenario, o los primerísimos planos a una mirada ilusionada, o a la furia ciega que transmite un taconeo, son escenas que dependen de la mediación de la cámara. Composición de cuadros, relación sintáctica entre planos, contrastes psicológicos entre tomas de campo y contracampo. 
INVESTIGACIÓNTEATRAL

Revista de artes escénicas y performatividad

Vol. 10, Núm. 15

abril-septiembre 2019
¿Cómo será la muerte, ese cesar de sentir?

(En torno a Bodas de sangre, de Antonio Gades)

Nidia Vincent

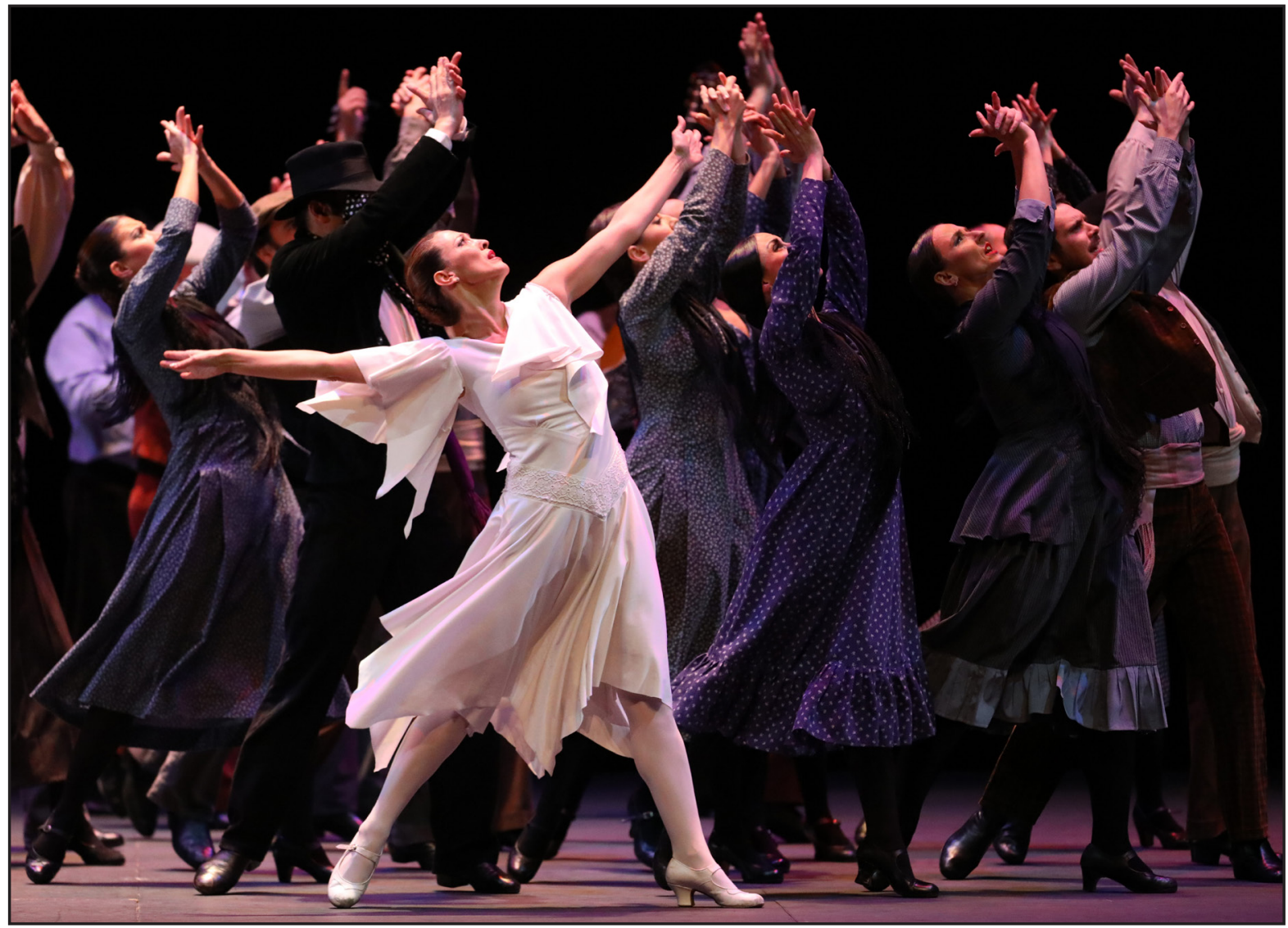

Bodas de sangre (c) Stanislav Levshin | Fundación Antonio Gades

\section{Navajas y presagios}

Dentro del universo lorquiano, se encuentran los puñales, pequeños y letales, escondidos en el fajín, prestos a desenvainarse para hundirse y acabar con la vida del adversario. "En la mitad barranco / las navajas de Albacete / bellas de sangre contrario / relucen como los peces", las describe el poeta en su poema "Reyerta". En el drama se resalta desde la primera escena su carácter negativo y su sola mención es un presagio, dice la Madre: "La navaja, la navaja... Malditas sean todas y el bribón que las inventó” (1082). Los puñales serán resaltados en la película con énfasis de las actuaciones, close-ups o cuando, en camerinos, uno de los bailarines prueba y saca brillo a su cuchillo. Principalmente, resultan protagónicos en las escenas en que la Madre quita el cuchillo a su hijo, y otra donde, enfáticamente, se lo entrega para que cumpla con su deber; así como en la contienda final. 
Gades conservó señales de presagio trágico, con gestos y miradas de la Madre y la Novia, con el paradójico desconsuelo de la alboreá ${ }^{16}$ que se canta para levantar a las muchachas el feliz día de su casamiento, en el tono de la tristísima nana con que arrullan al hijo de Leonardo y su mujer. Música, voz y letra conmueven y anuncian desdicha, a la vez que se introduce la figura del caballo herido:

Nana, niño, nana

del caballo grande

que no quiso el agua.

El agua era negra

dentro de sus ramas.

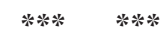

Las patas heridas, las crines heladas, dentro de los ojos un puñal de plata (1094).

\section{El caballo}

Se dijo previamente que en la adaptación se habían eliminado personajes de carga simbólica; sin embargo, Gades conservó y resaltó otros elementos emblemáticos de la estética de Lorca, como son los colores blanco y negro, la sangre, los azahares, las navajas y el caballo. Este último aparece de forma recurrente en los textos del granadino. Su propia naturaleza animal remite a fuerzas básicas, por encima de la razón o las normas sociales. Su ímpetu se impone a la voluntad y el decoro.

El caballo es símbolo de lo viril, lo instintivo y la vida (La casa de Bernarda de Alba), de la muerte (los oscuros caballos de la Guardia Civil o el caballo negro de algunos poemas), del ensueño y el amor (el caballo blanco de Santiago apóstol y de El público).

En Bodas de sangre, el caballo vuelve a representar al hombre, la fuerza sexual masculina que requiere de la hembra, y -como le confiesa a la Novia- caballo y jinete son uno:

16 La alboreá es un cante de las bodas gitanas. Proviene de albor, luz del alba, y se relaciona con la virginidad y desfloración de la novia. Por superstición, algunos gitanos no aceptan cantarlo fuera de una boda. 
LEONARDo. Pero montaba a caballo

y el caballo iba a tu puerta.

Con alfileres de plata

mi sangre se puso negra,

y el sueño me fue llenando

las carnes de mala hierba (1168).

O como en el diálogo entre el Novio y un Mozo, en el cual, el primero afianza la primacía de su masculinidad:

NOVIO. Por aquí

Mozo 1. No los encontrarás.

NOvio. (Enérgico) ¡Sí los encontraré!

mozo 1. Creo que se han ido por otra vereda.

Novio. No. Yo sentí hace un momento el galope.

Mozo 1. Sería otro caballo.

Novio. (Dramático) Oye. No hay más que un caballo en el mundo, y es éste. ¿Te has enterado? (1162).

Y será precisamente sobre un caballo que los amantes huyan, será el galope lo que los delate y será montando otro caballo que el Novio les dé alcance. Para representar este pasaje, los bailarines son a la vez caballo y jinete; simulan el paso del animal con sus pies y las actitudes de los jinetes del tronco a la cabeza. No es el trote rápido o desesperado de los perseguidores o fugitivos lo que se imita, sino un paso acompasado, mesurado, que por un lado permite seguir al grupo encabezado por el Novio, que busca vengar el honor, y por el otro, a la pareja que cabalga sincrónica y enamorada, sin la intención de escapar, en cuyos rostros se asoma la resignación y la conciencia de un amor marcado por la fatalidad.

\section{La pasión}

Tema central de la tragedia es la pasión, cómo ésta domina a los amantes y los lleva a desafiar las convenciones sociales. La fuerza de la atracción y el hondo conflicto que hunde a la pareja de amantes son expresados por el poeta en elocuentes versos:

LEONARDO. ¿Qué vidrios se me clavan en la lengua!

Porque yo quise olvidar 
y puse un muro de piedra entre tu casa y mi casa. $* * \% * \%$

Pero montaba a caballo

y el caballo iba a tu puerta (1167-1168).

NOViA. ¡Ay qué sinrazón! No quiero

contigo cama ni cena

y no hay un minuto del día

que estar contigo no quiera,

porque me arrastras y voy,

y me dice que me vuelva

y te sigo por el aire

como una brizna de hierba (1168).

La Novia desea unirse a su prometido y reconoce en él cualidades para una vida próspera, pero es imposible que se resista a su destino y a su deseo:

NOVIA. [...] tu hijo era un poquito de agua de la que yo esperaba hijos, tierra, salud; pero el otro era un río oscuro, lleno de ramas, que acercaba a mí el rumor de sus juncos y su cantar entre dientes. Y yo corría con tu hijo que era como un niñito de agua, frío, y el otro me mandaba cientos de pájaros que me impedían el andar y que dejaban escarcha sobre mis heridas de pobre mujer marchita, de muchacha acariciada por el fuego. Yo no quería, ¡óyelo bien!, yo no quería. ¡Tu hijo era mi fin y yo no lo he engañado, pero el brazo del otro me arrastró como un golpe de mar, como la cabezada de un mulo, y me hubiera arrastrado siempre, siempre, siempre, aunque hubiera sido vieja y todos los hijos de tu hijo me hubiesen agarrado de los cabellos! (1179).

Esta fuerza de atracción que anima toda la trama, está representada en la danza-teatro sobre todo en tres momentos:

1. En la tercera escena, donde con absoluta libertad -ya que no corresponde a ningún fragmento del drama de Lorca- se impone un lirismo coreográfico y plástico que iguala al erotismo expresivo de las palabras: ${ }^{17}$

17 En la película, la escena está focalizada mediante una inesperada toma cenital; la cámara capta la coreografía en que se representa cómo los amantes se desean, con desesperación, a la distancia. Los movi- 
Escena tercera: Leonardo se queda solo en el escenario, pensativo, mirando a la lejanía, evocando a alguien. Ese alguien está lejos, pero la imaginación de Leonardo borra la distancia y su deseo se materializa: aparece la Novia, que en enaguas y corpiño, se deja vestir para la ceremonia de la boda. Da comienzo la danza del amor oculto. Leonardo abraza imaginariamente a la Novia. La Novia, en su casa, acaricia su propio cuerpo como si sus manos fuesen las manos de Leonardo. En este acto de amor imaginario, Leonardo y la Novia toman su deseo por realidad, y se encuentran bailando juntos una danza llena de lirismo y sensualidad. En este momento entra la mujer de Leonardo y la ensoñación de Leonardo se desvanece (Domínguez et al 13).

2. Posteriormente, cuando en plena fiesta de la boda (cuarta escena), un pasodoble es el pretexto para que los cuerpos de Leonardo y la Novia vibren al entrar en contacto.

3. Y por último, cuando la pareja huye a caballo (quinta escena), episodio en el que la mujer se ciñe a la espalda del amado, recuesta en él su cabeza, y ambos bailarines parecen desplazarse sobre un caballo mediante el solo desliz de sus pies. La ausencia de música y cantos produce un efecto de suspense, intensificado por el roce rítmico de los zapatos sobre la duela tanto de perseguidos como de perseguidores.

\section{Rivalidad}

El otro gran tema central y fuente de conflicto en el drama es la rivalidad: una añeja disputa entre familias y el antagonismo entre dos varones enamorados de la misma mujer. Gades da un tratamiento relevante a este asunto, al que dedica la sexta y última escena de la danza-teatro (correspondiente al cuadro último del segundo acto y al tercer acto en la obra original). Mientras que el ballet muestra en escena la persecución, la huida y el duelo entre ambos rivales, en el texto de García Lorca estos pasajes son anunciados o descritos por otros personajes, por ejemplo, en un diálogo entre la Criada y la Esposa: “ ¡Han huido! ¡Han huido! Ella y Leonardo. En el caballo. Iban abrazados, como una exhalación” (1153); un parlamento entre el Novio y uno de los mozos u otro de la Luna agorera y delatora: "Ya se acercan unos por la cañada y el otro por el río. Voy a alumbrar el río" (1161); además de comentarios de los leñadores a modo de coro clásico: "El novio los encontrará con luna o sin luna. Yo lo vi salir. Como una estrella furiosa. La cara color ceniza. Expresaba el sino de su casta" (1157).

mientos de los bailarines en el suelo (inusuales en el flamenco), sus gestos faciales y las guitarras son los medios para hablar de una pasión contenida, expresada como sueño o añoranza. 
La coreografía recrea, con el cese repentino de la música y la algarabía, el cambio de ánimo que suscita saber que la Novia ha escapado. Las palabras de la Madre: "Dos bandos. Aquí hay dos bandos. Mi familia y la tuya" (1154), toman forma visual con el intercambio de miradas de desconfianza y desconcierto entre todos los invitados, acompañadas por un simultáneo chasquido de dedos que acentúa el clima tenso en que se transformó la fiesta. La cámara, por su parte, incrementa esta tensión mediante paneo y primeros planos de las manos y rostros. Al finalizar la escena, los invitados quedan separados en dos grupos; la misma Madre entrega la navaja al Novio y le señala el rumbo por el que debe salir a limpiar su nombre.

\section{Muerte y tragedia}

El artículo de 1928 del periódico $A B C$ se publicó bajo el siguiente título: "Crimen desarrollado en circunstancias misteriosas", fue una escueta nota del caso. Respecto al asesinato se limita a consignar lo siguiente: "Detenida la novia, manifestó que había huido en unión de su primo para burlar al novio. La fuga la emprendieron en una caballería, y al llegar al lugar del crimen les salió al encuentro un enmascarado, que hizo cuatro disparos, produciendo la muerte de Montes Cañada [el primo]."

La nota, como salta a la vista, no es excepcional tan sólo los términos "misteriosas" y "enmascarado" producen cierta curiosidad; sin embargo la circunstancia de la huida y la emboscada cobarde de que es víctima la pareja resulta bastante ordinaria. Caso muy distinto ocurre cuando el hecho es transmutado por la imaginación y el lenguaje del poeta. Lorca "organiza nuestra mirada" - como pide Dubatti- y nos expone a fuerzas antagónicas y esenciales de la naturaleza humana: celos, virilidad, erotismo, venganza, violencia.

La poesía y el teatro de Lorca siempre estuvieron en tratos con la muerte. Mas no con la muerte lenta, enfermiza o discreta, sino con la otra: beligerante, traicionera y adelantada; aquella teñida de rojo y que, paradójicamente, se sustenta de la vida a la vez que la sostiene - porque, como escribió Octavio Paz: "El culto a la vida, si en verdad es profundo y total, es también culto a la muerte. Ambas son inseparables. Una civilización que niega a la muerte acaba por negar también a la vida"- (54).

Bodas de sangre une en su título dos condiciones de la existencia: la boda, como promesa de la unión fértil, de dos que dejan su individualidad para ser con otro; frente a la sangre, símbolo antagónico de la pareja indisoluble de Eros y Thanatos. Las nupcias, que legitiman la unión de la pareja ante Dios y los hombres, son atropelladas por la fuerza soberana del deseo, por una savia erótica que obliga a la fusión de los cuerpos, sin importar las consecuencias. Porque a estas "bodas" las avala una ley natural, superior e insoslayable que desafía el orden social, tal como discurren los Leñadores a modo de coro clásico: 
LEÑADOR 1. Se estaban engañando uno a otro y al fin la sangre pudo más.

LEÑADOR 3. ¡La sangre!

LEÑADOR 2. Pero sangre que ve la luz, se la bebe la tierra.

LEÑADOR 1. ¿Y qué? Vale más ser muerto desangrado, que vivo con ella podrida (1156).

En la obra de Lorca, ambos hombres mueren en un duelo. Pero al modo de las tragedias clásicas, dicha escena no se muestra al público y es referida solamente por algunos parlamentos de la Madre, la Novia y tres personajes femeninos secundarios, que remiten a las Parcas (Mendiga, Muchacha 1 y 2).

MUCHACHA 1. Amante sin habla

Novio carmesí.

Por la orilla muda

tendidos los vi (1173).

MENDIGA: Flores rotas los ojos, y sus dientes

dos puñados de nieve endurecida.

Los dos cayeron, y la novia vuelve

teñida de sangre falda y cabellera.

Cubiertos con dos mantas ellos vienen

sobre los hombros de los mozos altos.

Así fue; nada más. Era lo justo.

Sobre la flor del oro, sucia arena (p.1176).

Lorca evita mostrar el combate, confiando a la palabra poética la fuerza y el dibujo de la escena y el desenlace. El público (o el lector) se sobrecoge de miedo y compasión con los parlamentos de las mujeres luctuosas que han quedado solas:

MADRE. Vecinas, con un cuchillo, con un cuchillito, en un día señalado, entre las dos y las tres, se mataron los dos hombres del amor.

Con un cuchillo, con un cuchillito que apenas cabe en la mano, pero que penetra fino por las carnes asombradas, 
y que se para en el sitio

donde tiembla enmarañada

la oscura raíz del grito.

NOVIA. Y esto es un cuchillo,

un cuchillito

que apenas cabe en la mano;

pez sin escamas ni río,

para que un día señalado, entre las dos

y las tres, con este cuchillo,

se quedan dos hombre duros con los labios amarillos.

MADRE. Y apenas cabe en la mano,

pero que penetra frío

por las carnes asombradas

y allí se para en el sitio

donde tiembla enmarañada

la oscura raíz del grito (1181-1182).

La pieza de danza-teatro fue más explícita en su representación, llevando a la escena el enfrentamiento cuerpo a cuerpo. Quizá esto se debió a que los movimientos estilizados de la danza, y el dominio de la técnica de los bailarines, son capaces de distanciarnos de un realismo burdo y lograr así una metáfora, que es lo propio de la poiesis de acuerdo a Dubatti: "Las acciones son además no naturales, es decir, diferenciadas de las acciones reales, ya por su misma génesis - acciones que no observamos en el mundo cotidiano- o porque al ser tomadas por la matriz de la poíesis mutan: acciones despragmatizadas de su función en la empiria y transformadas en poesía" (“Cuerpo social” párrafo 10).

Se trata de una escena de potente significación dramática, la más importante del ballet y la que representó -en palabras del propio Gades- la actuación más difícil de su carrera artística. Veamos el tratamiento que con el lenguaje dancístico se dio a este pasaje, teniendo en mente que un cuerpo sedente o uno en movimiento son también una "escritura corporal" que puede ser interpretada (ver Leigh). En el baile flamenco, el taconeo o las palmas marcan el ritmo como un instrumento de percusión, mientras que el cuerpo es un instrumento silencioso; toque, manos y brazos tienen mayor carga expresiva.

Tras una discusión acalorada, marcada por el taconeo exaltado de ambos rivales y los ruegos infructuosos de la Novia, ambos bailarines se quitan los chalecos mientras desenvainan a la vez sus relucientes cuchillos, que presentan al contrario (como el instrumento de un ritual de honor y hombría). Con estos signos no lingüísticos se parafrasea, es decir, 
INVESTIGACIÓNTEATRAL

Revista de artes escénicas y performatividad

Vol. 10, Núm. 15

abril-septiembre 2019
¿Cómo será la muerte, ese cesar de sentir?

(En torno a Bodas de sangre, de Antonio Gades)

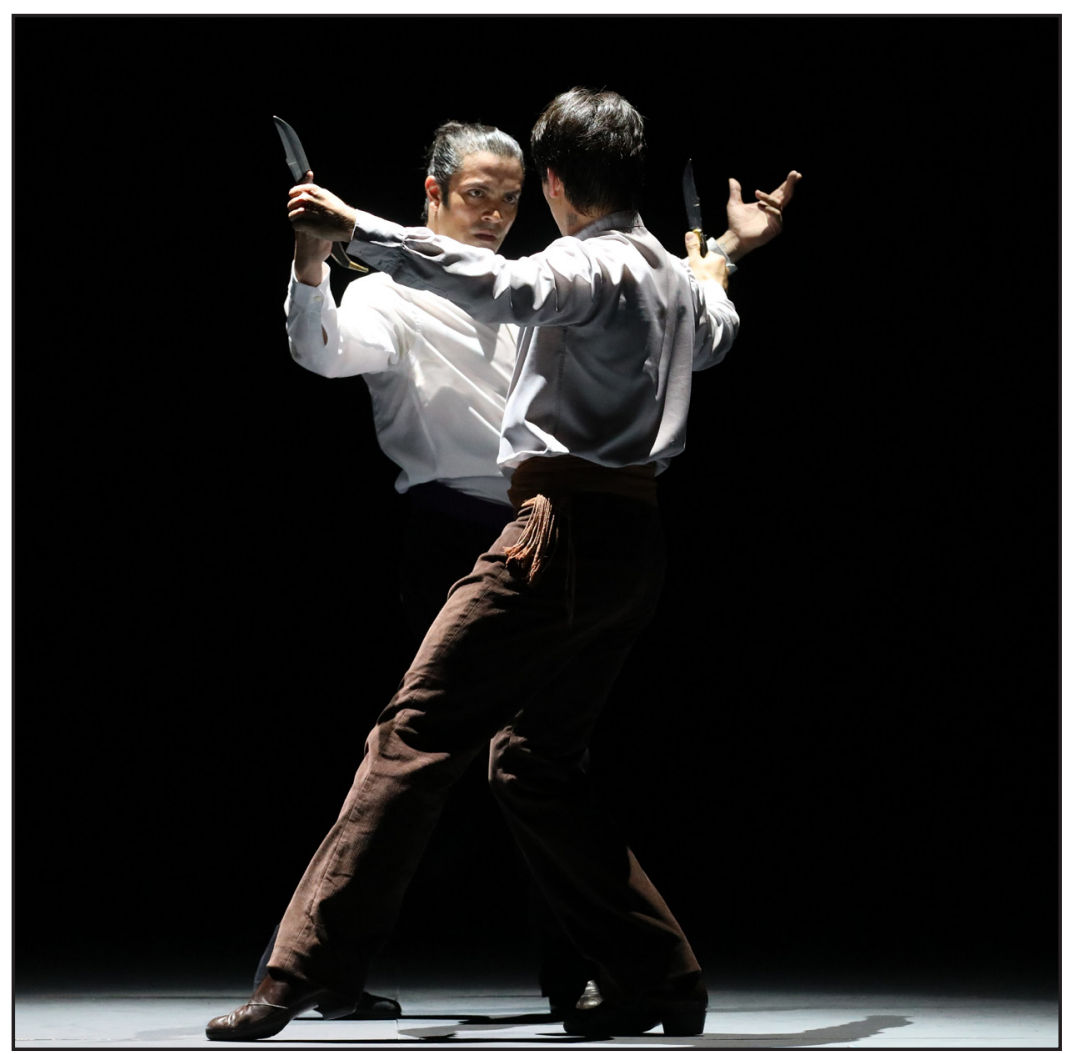

Bodas de sangre ${ }^{\circ}$. Stanislav Levshin | Fundación Antonio Gades

se envían a otro registro las palabras que el poeta puso en boca de la Mendiga: "Ilumina el chaleco y aparta los botones, que después las navajas ya saben el camino."

En silencio se ejecuta una coreografía de una tensión y un virtuosismo notables. La atención se centra en el tour de force de los dos bailarines. Su energía vital y talento, toda su técnica y experiencia se dieron cita para transmitir la intensidad de quien, con la misma fuerza con que lucha por destruir a su enemigo, defiende el honor, la hembra y la vida. Ambos ejecutan muy lentamente movimientos simétricos y simultáneos, como en espejo. Amar a la misma mujer los iguala. Ambos son jóvenes y apuestos, son miembros de familias rivales y sus vidas son igualmente valiosas, como dice la Niña: "Morenito el uno/ morenito el otro" (1177).

La cámara capta un par de veces, en segundo plano y en medio de los rivales, a la Novia. Con close-ups se enfatiza la angustia de sus rostros. En un tercer plano, se observa a los otros miembros de la compañía provocando un momentáneo distanciamiento que no minimiza la potencia iluminadora y catártica de la escena. Dolor y placer se dan cita, como en un lamento de cante jondo. 
Sin montajes atrevidos ni efectos, sin ralenti o congelados, el lente es un mudo testigo absorto y extasiado, que capta el clímax de la muerte. Los adversarios se encuentran en un baile circular, la rabia los habita. Forcejean: peligrosamente las cuchilladas se acercan, los rozan, se hienden. Esta intensa escena, que se prolonga por más de cuatro minutos, ocurre en un silencio siniestro, únicamente interrumpido por la respiración de los combatientes. Asistimos a la reyerta, al hendirse de los aceros en la carne, al desplomarse de los cuerpos, a la rápida agonía. Cuando se hieren mortalmente uno al otro, la aterradora escena se inunda de un palmeo rápido e intenso de todos los bailarines secundarios y unos gritos de jaleo incomprensibles que no son de dolor ni de confusión, sino sincrónicos y repetidos como parte de un antiquísimo ritual. Ambos sonidos van in crescendo y los hombres mueren sin aspavientos ni patetismo.

Dos jóvenes viriles yacen en el suelo. Sorprende que el acto de matar requiera de una vitalidad inigualable, de un arrojo desmedido, de una osadía extrema, porque en la muerte del otro va la sobrevivencia de uno mismo. Vemos en los personajes a la muerte, ese cesar de sentir, al extraño alejamiento que no percibe ya lo que le rodea, al cadáver que no es ya la muerte sino un muerto, a la vida que se alejó de golpe, que llegó a su fin sin continuidad. Vemos a los vivos, que tienen que seguir viviendo. Imposible saber de qué se despide un hombre con el último aliento.

Los receptores quedamos sumisos ante una experiencia contundente de temor y gozosa contemplación estética que nos enfrenta a nuestra frágil condición. La experiencia de muerte está en cada uno de nosotros, única e intransmisible. Sólo el arte nos regala, en una experiencia de horror sublime, asomarnos momentáneamente a sus ojos.

Largo y curioso es el trayecto de transformación que han recorrido los hechos del "crimen de Níjar", desde la realidad consignada en una breve nota periodística, hasta la coreografía plasmada y fijada en una película. La realidad fue sólo el detonante para la creatividad de Lorca; para que el "Duende" -como él lo nombra- lo habitara a él, y luego a Gades y posteriormente a Saura. El Duende, fuerza compatible con el alma española, energía creativa que no es musa, ni ángel, ni demonio teológico. Como lo explica el propio Federico en su "Teoría y juego del duende":

[...] el duende es un poder y no un obrar, es un luchar y no un pensar. Yo he oído decir a un viejo maestro guitarrista: "El duende no está en la garganta; el duende sube por dentro desde la planta de los pies". Es decir, no es cuestión de facultad, sino de verdadero estilo vivo; es decir, de sangre; es decir, de viejísima cultura, de creación en acto (37).

Fue el Duende, el mundo andaluz y el flamenco los que establecieron los sólidos y profundos vasos comunicantes entre estos artistas, así como entre ellos y su teatralidad poética. Fueron el Duende y la teatralidad de esta danza los que mediaron para que nos allegáramos a la zona normalmente inaccesible de matar y morir. 


\section{Fuentes consultadas}

"Crimen desarrollado en circunstancias misteriosas". $A B C, 25$ de julio de 1928 [edición de la mañana], p. 22.

Artaud, Antonin. El teatro y su doble. Traducido por Enrique Alonso y Francisco Abelenda. Ciudad de México: Hermes, 1978.

Auclair, Michelle. Vida y muerte de Federico García Lorca. Ciudad de México: Era.

Azcue, Verónica. "Apuntes sobre la filmación de un mito. Bodas de sangre: del teatro a la danza y de la danza al cine". Revista Latente, núm. 1, 2003, pp 45-56.

Brao, Estefanía. Baile flamenco: observación y análisis del Taranto en los ámbitos profesional y académico. Reflexión metodológica. Tesis de doctorado, Universidad de Murcia, 2014.

Domínguez, Isabel, et al. Antonio Gades. Federico García Lorca. Bodas de sangre. Guía didáctica. Madrid: Fundación Antonio Gades, Comunidad de Madrid, Ayuntamiento de GETAFE, 2009, www. antoniogades.com/images/guias_didacticas/Guia_didactiCa_BODAS_DE_SANGRE_Fundacion-Antonio-Gades.pdf, consultado el 15 de septiembre de 2016.

Dubatti, Jorge. "Teatro-matriz y teatro liminal. La liminalidad constitutiva del acontecimiento teatral". Revista Conjunto, núm. 185, octubre-diciembre 2017, pp. 80-94, www.casa.co. cu/publicaciones/revistaconjunto/185/13Jorge.pdf, consultado el 6 de mayo de 2018.

Dubatti, Jorge. "Cuerpo social y cuerpo poético en la escena argentina". E-misférica, vol. 4, núm. 2, noviembre 2007, www.hemisphericinstitute.org/journal/4.2/esp/es42_pg_ dubatti.html, consultado el 2 de septiembre de 2018.

Dubatti, Jorge. "Convivio y tecnovivio: el teatro entre la infancia y el babelismo", Revista Colombiana de las Artes Escénicas, vol. 9, enero-diciembre 2015, pp. 44-54, artescenicas.ucaldas.edu.co/downloads/artesescenicas9_5.pdf, consultado el 12 de diciembre de 2018.

García Lorca, Francisco. Federico y su mundo. Madrid: Alianza, 1980.

García Lorca, Federico. "Bodas de sangre”. Obras completas. 4a. ed. Madrid: Aguilar, 1962, pp. 1081-1182.

García Lorca, Federico. “Teoría y juego del duende”. Obras completas. 4a. ed. Madrid: Aguilar, 1962. pp. 36- 48.

Lábatte, Beatriz. "Teatro-danza. Los pensamientos y las prácticas". Cuadernos del Picadero, año 3, núm. 10, septiembre, 2006.

Leigh, Susan. "Coreografiar la historia". Lecturas, danza y coreografía, Artea, 2013, loinsignificante.files.wordpress.com/2014/07/lecturassobredanzaycoreografiaok.pdf, consultado el 22 de septiembre de 2016. 
INVESTIGACIÓNTEATRAL

Revista de artes escénicas y performatividad

Vol. 10, Núm. 15

abril-septiembre 2019
¿Cómo será la muerte, ese cesar de sentir?

(En torno a Bodas de sangre, de Antonio Gades)

Nidia Vincent

López Ruiz, Luis. Guía del flamenco. Madrid: Akal, 2007.

Naverón, Isabel de y Amparo Écija, "Leer, bailar, escribir". Lecturas, danza y coreografía, Artea, 2013, loinsignificante.files.wordpress.com/2014/07/lecturassobredanzaycoreografiaok.pdf, consultado el 28 de septiembre de 2016.

Paz, Octavio. “Todos Santos. Día de Muertos". El laberinto de la soledad. Ciudad de México: Fondo de Cultura Económica, 1982, pp. 42-58.

Pineda, Daniel, "Lorca y el flamenco". MonteAgudo, 3a. época, núm. 12, 2007, pp. 169-184

Rolph, Wendy. "Lorca/Gades/Saura: Modes of Adaptation in Bodas de sangre". Anales de la Literatura Española, núm. 11 (1-2), pp. 205-213.

Sedeño, Ana María, "La Generación del 27 y la música: el flamenco". Sinfonía virtual, núm. 7, 2008, www.sinfoniavirtual.com/revista/007/generacion_27_y_musica_flamenco. php, consultado el 18 julio de 2018.

Crónica del suceso de Bodas de sangre, libreto de Alfredo Mañas a partir del drama de Federico García Lorca. Dirigida por Carlos Saura. Antonio Gades, Compañía Antonio Gades,1974, estreno en Teatro Olimpia, Roma, 1974. 


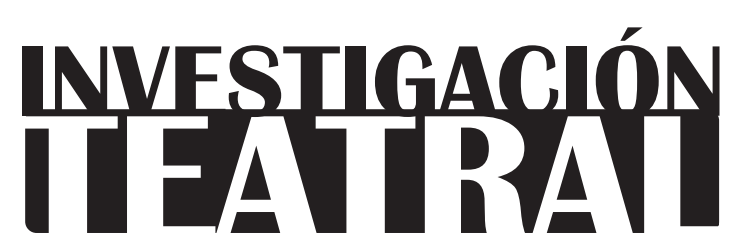

Revista de artes escénicas y performatividad

Vol. 10, Núm. 15

abril-septiembre 2019

Segunda época

ISSN impreso: 1665-8728

ISSN electrónico: 2594-0953

Universidad Veracruzana

\section{Meyerhold, entre la técnica extracotidiana de inculturación y aculturación. Estudio desde la antropología teatral}

Sergio Naranjo Velásquez*

\footnotetext{
* Departamento de Artes Escénicas de la Universidad de Caldas, Manizales, Colombia.

e-mail: sergionaranjo13@gmail.com
}

Recibido: 23 de noviembre de 2018

Aceptado: 15 de febrero de 2019 
INVESTIGACIÓNTEATRAL

Revista de artes escénicas y performatividad

Vol. 10, Núm. 15

abril-septiembre 2019
Meyerhold, entre la técnica extracotidiana

de inculturación y aculturación

Sergio Naranjo Velásquez

\section{Meyerhold, entre la técnica extracotidiana de inculturación y aculturación. Estudio desde la antropología teatral}

\section{Resumen}

Este artículo estudia, desde la antropología teatral de Eugenio Barba, si la biomecánica de Meyerhold se basa en una técnica extracotidiana de inculturación o en una técnica extracotidiana de aculturación. Esta investigación permite enlazar concepciones que, a priori, se presentan separadas, demostrando que la técnica extracotidiana inculturada y la técnica extracotidiana aculturada tienen elementos que se relacionan. Aunque parezca paradójico encontrar símiles entre estos conceptos, que tradicionalmente se han considerado "opuestos", se constatan y contrastan de forma indirecta los principios técnicos inculturados y aculturados, que hoy se trabajan desde el punto de vista de la antropología teatral.

Palabras clave: antropología teatral, cuerpo, pre-expresividad, biomecánica.

\section{Meyerhold, between the Extra-quotidian Techniques of Enculturation and Acculturation. A View from Theater Anthropology}

\section{Abstract}

Based on Eugenio Barba's Theater Anthropology, this article examines whether Meyerhold's Biomechanics is based on either of the extra-quotidian techniques of enculturation or acculturation. The purpose is to link these two hitherto separated and even opposite concepts, and to demonstrate that both techniques, as understood in Theater Anthropology, have elements in common.

Keywords: Theater Anthropology, body, pre-expressivity, Biomechanics. 


\section{Meyerhold, entre la técnica extracotidiana de inculturación y aculturación. Estudio desde la antropología teatral ${ }^{1}$}

\section{Técnica extracotidiana de inculturación y aculturación}

$\mathrm{P}$ artiendo del concepto y significado de la antropología teatral, conociendo su estructura y forma de proceder en referencia a la técnica del actor en el campo de la pre-expresividad, este artículo analiza el principio básico que sustenta la presencia del actor sobre el escenario que, según dicha disciplina, es la diferenciación entre técnica cotidiana y técnica extracotidiana. Se trata de uno de los aspectos más complejos y criticados en la propuesta antropológica de Eugenio Barba.

En su libro Hacia un tercer teatro, Ian Watson resume el pensamiento de Barba acerca de las técnicas corporales de la vida cotidiana, diciendo que éstas equivalen simplemente a "acciones físicas automatizadas". En efecto, al referirse a las técnicas cotidianas, Barba afirma sumariamente que los comportamientos automatizados pueden considerarse habituales, y no se detiene a explicitar las cualidades que puede presentar una técnica cotidiana. En vez de ello, su antropología teatral se centra en las técnicas extracotidianas del cuerpo, entendidas como técnicas con fines primariamente escénicos. En tal contexto, lo importante radica en abordar aquellas técnicas que traspasan los condicionamientos cotidianos del cuerpo, visualizando aquellos movimientos que son mucho más complejos (de una dificultosa artificialidad) y amplifican la presencia de un cuerpo en una situación de

1 Este artículo ha sido escrito a partir del capítulo v de mi tesis doctoral, titulada "La técnica extracotidiana en la creación del cuerpo escénico: inculturación y aculturación, análisis y modelo pedagógico", dirigida por el doctor Francesc Xavier Escribano López. 
representación, donde el gasto energético es el máximo en comparación con el que utilizan las acciones cotidianas. A partir de tales movimientos y acciones, Barba elabora su teoría de las técnicas extracotidianas.

Dicha teoría, no obstante, deja entrever un nuevo matiz al referirse a la existencia de dos puntos de partida para trabajar los comportamientos extracotidianos, es decir, la lógica de la inculturación, frente a la lógica de la aculturación:

Una es un punto de salida que sigue la lógica del comportamiento cotidiano, sigue la lógica de la inculturación para llegar a una dilatación de las energías. Es lo que se encuentra como el método o el punto de salida dominante en la cultura teatral occidental, es el método de Stanislavski organizado. Es decir, crea sobre el escenario una presencia que toma como punto de salida la coherencia de la vida cotidiana, pero no la imita sino que reconstruye los procesos que la caracterizan de manera dilatada y consecuente (Barba, "La conferencia de Santiago" 89).

La técnica de la aculturación, en cambio, busca crear una otra cultura física, la modelación del cuerpo desde el exterior, que no responde ya a la lógica de la técnica cotidiana ni al camino de la inculturación:

La técnica de aculturación vuelve artificial (o 'estiliza', como se dice a menudo) el comportamiento del actor-bailarín, pero al mismo tiempo crea otra calidad de energía. Todos hemos tenido esa experiencia al ver a un actor clásico hindú o japonés, a un bailarín moderno o a un mimo. Es fascinante hasta qué punto han logrado modificar su 'naturaleza', transformándola en ligereza como en el ballet clásico, o en el vigor de un árbol en la danza moderna. La técnica de aculturación es distorsión de la apariencia para recrearla sensorialmente más real, fresca y sorprendente (Barba y Savarese 279).

Vistos los conceptos de técnicas extracotidianas de inculturación y aculturación, a continuación pasamos a estudiar si la biomecánica de Meyerhold se basa en una u otra técnica. 


\title{
Vsevolod Meyerhold y la corriente simbolista
}

\author{
"Si la punta de la nariz trabaja, todo el cuerpo también \\ trabaja".
}

Meyerhold (citado en Law y Gordon 135)

Vsevolod Meyerhold (1874-1940)² fue un actor, director y teórico teatral que impulsó el antinaturalismo, en contraposición al naturalismo que promovía Stanislavski. ${ }^{3}$ En 1898 había trabajado con él en el Teatro de Arte de Moscú (TAM), donde conoció de primera mano las investigaciones del método stanislavskiano (en aquel momento transitaban por su primera etapa). Precisamente, su inconformidad con el entrenamiento actoral naturalista y su fuerte atracción por la corriente simbolista lo conducen a abandonar el TAM en 1902, decidido a probar nuevos caminos ${ }^{4}$ que desembocarían en su propia teoría y el lugar destacado que ésta ha tenido para la historia teatral del siglo xx.

Tanto la formación actoral, como la relación con el espectador y el carácter social (tercer teatro), son los principios fundamentales en las teorías de Meyerhold, los cuales pueden encontrar eco en los postulados teórico-metodológicos de la antropología teatral. Eugenio Barba siempre ha destacado el papel que tuvo Meyerhold en la creación de su propia teoría: "A continuación me dirigiré a los muertos, a los libros-fuentes de la 'ciencia' del teatro. Sobre mi escritorio están Stanislavski, Meyerhold y Brecht" (Barba, Más allá de las islas 129).

2 Meyerhold, en 1939, fue detenido y torturado por el Partido Comunista de Stalin; en febrero de 1940 es acusado de trotskista, espía británico y japonés, lo cual desemboca en su fusilamiento.

3 Galina Tolmacheva, quien fuera discípula de Stanislavski, comenta sobre esta aparente oposición: "Psicotécnica y Biomecánica. Stanislavski y Meyerhold ¿Qué diferencia y qué semejanza! Dos extremos, dos polos tan opuestos como parecidos. Ambos parten de la técnica pura. Uno se consagra al minucioso trabajo analítico en el campo de las posibilidades psíquicas del ejecutante, y aspira a llegar al perfeccionamiento artístico mediante el desarrollo y entrenamiento casi científico de la psiquis del actor; el otro hace lo mismo en cuanto a las posibilidades físicas, y procura lograr la misma perfección desarrollando casi científicamente las condiciones físicas del intérprete" (Tolmacheva 367).

4 En esta época empiezan a aparecer nuevas corrientes estéticas que pretenden romper con la estructura naturalista (la ópera y el ballet son pioneros en este cambio), siendo que el "principal responsable de estas innovaciones era un movimiento, 'El mundo del Arte', con una revista literaria del mismo nombre fundada en 1898. Esta revista tenía como programa desafiar el academicismo y el naturalismo en iniciar la lucha contra la estética materialista o de intención social. Pero lo más importante no fue lo que negó, sino lo que promocionó y propagó. Dio un gran impulso a todas las artes visuales, iniciando el movimiento de las artes gráficas y el grabado" (Meyerhold, Teoría Teatral 11). 
El "nuevo teatro" o teatro de "convención consciente" -como lo llamó Meyerhold, interesado en que "la plástica no correspondiera a las palabras"-, generó un trabajo de estilización: "Este concepto nace de la necesidad de sacar a los actores de la anarquía del teatro naturalista para llevarlos a una toma de conciencia en cuanto a los principios organizativos de un teatro de realismo convencional" (Meyerhold, El actor 165).

El procedimiento teatral que Meyerhold lleva a cabo, persigue como objeto estético una puesta en escena de carácter artificial: "una dramaturgia y una puesta en escena que no oculten los procedimientos de construcción y de funcionamiento teatral” (Pavis 356). Esta nueva concepción difiere de la consigna del teatro naturalista; sin embargo, Meyerhold matiza su separación del realismo ilustrado, logrando por medio de la abstracción estilizar la realidad.

Meyerhold encontró en el simbolismo ${ }^{5}$ equivalentes plásticos con los cuales comunicar la realidad; se interesaba por una composición plástica que no concordase con las palabras, gestos corporales y texto hablado. Para Meyerhold, cada uno de estos elementos puede tener su propio ritmo y en ocasiones aparecer desligado de los otros.

\section{Teatro de la convención consciente}

Gordon Craig, en 1910, ya se refería al simbolismo como un bien sensato, ordenado y universal," "porque el simbolismo se encuentra en las raíces no sólo del arte, sino de la vida misma; es sólo por medio de símbolos que la vida se vuelve posible" (286).

5 La corriente simbolista nace a finales del siglo xIX como un movimiento en contraposición al naturalismo y realismo de la época. Para Dan Sperber, "el simbolismo es un segundo modo de acceso a la memoria adoptado cuando fracasa el primero y que permite la interpretación de la información. Así, podríamos suponer que la cognición en el hombre es el primer mecanismo adaptativo. Por ejemplo, cuando una serie de acontecimientos o datos se presentan sin una causa primera, se elabora una construcción mental simbólica: para el primitivo, ésta remitirá a los espíritus y para el científico, a ciertos principios axiomáticos" (15). Con esto, Sperber da entender que el proceso cognitivo que realiza nuestra mente permite alcanzar, por medio del simbolismo, un aprendizaje y una forma de expresión liberadora del ser humano.

6 Gordon Craig, en referencia a que el símbolo es utilizado universalmente, da los siguientes ejemplos: "Las letras del alfabeto son símbolos que empleamos cotidianamente. Los números son símbolos, y la química y la matemática los utilizan. Todas las monedas del mundo son símbolos; y los hombres de negocios tienen confianza en ellos. La corona y el cetro de los reyes, así como la tiara de los papas son símbolos. Las obras de los pintores y de los poetas, de los arquitectos y los escultores, están llenas de simbolismo; los chinos, los egipcios, los griegos, los romanos y los artistas modernos han entendido y apreciado en su valor al símbolo" (286). 
Para utilizar todos estos símbolos en escena, deben existir, en primera instancia, una serie de convenciones ${ }^{7}$ tanto para el actor como para el espectador; son como las reglas de un juego: se requiere consciencia sobre ellas y que sean respetadas. Lo que se presenta en el juego teatral ya no es observado como algo real (naturalista), sino como una ficción ${ }^{8}$ que está elaborada por medio de signos, donde predomina el cuerpo con su diseño de movimiento, plástica y musicalidad.

Para este nuevo teatro:

Por fin, la técnica convencional supone en el teatro, después del autor, escenógrafo y actor, al cuarto creador: el espectador. El teatro de convención elabora puestas en escena donde el espectador, con su imaginación, debe completar de manera creativa el dibujo de las ilusiones dadas allí en escena (Meyerhold, Écrits sur le Théâtre 116).

El espectador de este teatro deja de ser un ente estático; ahora se le anima a pensar y a discutir, ya no se trata sólo de una sensibilidad emotiva sino de una sensibilidad sensorial. Según Barba: "Meyerhold quiere provocar en el espectador un reflejo emocional que no pasa necesariamente a través del aspecto intelectual, sino que se basa en la sensibilidad sensorial y cinestésica" (Barba y Savarese 179), algo con lo que su antropología teatral está de acuerdo, al considerar que un mismo espectáculo puede convertirse en una auténtica "expedición antropológica". Se crea una experiencia tanto para el actor como para el espectador, sin que esto signifique que tiene que ser la misma para los dos. ${ }^{9}$

7 Bertold Brecht, años más tarde, también crearía una serie de convenciones para crear su conocido efecto de distanciamiento, con el cual se oponía a la tendencia de los espectadores a identificarse con los personajes, sin llegar a tener alguna reflexión crítica.

8 Comenta Meyerhold, en 1907, que "en el teatro de la convención consciente, el espectador no olvida un instante que tiene delante a un actor que representa, como el actor no olvida un instante que se trata de colores, de tela, de pinceles y, sin embargo, se percibe un sentimiento de la vida sublimado, depurado. Sucede, a menudo, que, cuanto más parece un cuadro, más potente es el sentimiento de la vida" (Meyerhold, Teoría Teatral 54). Es un teatro que lucha contra la ilusión que quería plasmar a toda costa el teatro naturalista.

9 Eugenio Barba, en su artículo "Abuelos y Huérfanos", habla sobre la perspicacia que deben tener tanto el espectador como el actor: "No quiere decir que uno y otro perciban la misma experiencia realizando la acción teatral o asistiendo a ella. Un actor puede realizar una exploración personal y buscar un sentido, en y con el microcosmos de su cuerpo-mente, que permanece independiente en relación con el sentido y la exploración que realiza el espectador asistiendo al espectáculo" (Barba y Savarese 89). 


\section{Cotidianidad grotesca}

Para cambiar la percepción del espectador y del actor, Meyerhold recurre al género grotesco $^{10}$ que ya estaba instaurado en la literatura, la música y las artes plásticas. En efecto, encuentra en el género una nueva forma de observar la vida cotidiana, de profundizarla por medio del contraste, según lo exponía en 1912:

Al grotesco le está permitido aproximarse de modo insólito a la vida cotidiana. El grotesco permite precisamente la vida cotidiana, cesando de representarse sólo lo que es habitual. En la vida, además de lo que vemos, hay también un vastísimo sector inexplorado. El grotesco, buscando lo sobrenatural, junta en síntesis la escénica de los contrarios, crea un cuadro del fenómeno e induce al espectador a la tentativa de resolver el enigma de lo incomprensible (Meyerhold, Meyerhold: Textos Teóricos 195).

Este nuevo enfoque de lo cotidiano, refleja que Meyerhold -al igual que Stanislavski- tuvo presentes en su trabajo teatral a los elementos de la vida cotidiana; la diferencia reside en que Meyerhold lo hacía a través de una estilización de la realidad (la forma exterior en la que se dilata el cuerpo aculturado), mientras que Stanislavski refleja la vida cotidiana como un efecto de ilusión, que se inicia con la dilatación de la mente sobre el cuerpo inculturado:

Para Meyerhold, el grotesco constituye un 'nuevo enfoque de lo cotidiano', el grotesco 'profundiza lo cotidiano... El grotesco está regido así por la ley de la disonancia. Ésta permite constituir una suerte de coincidentia oppositorum que se convierte en el principio creador y filosófico del teatro, el soporte de la visión de mundo de Meyerhold, quien aspira a una 'belleza armoniosa' que asegure la disonancia. Por lo tanto, justamente gracias al grotesco $^{11}$ y a esta belleza armoniosa, el cotidiano será vencido en el cotidiano (De Toro 156-57).

10 El género grotesco, aplicado al teatro, la dramaturgia y la presentación escénica, tiene la intención de "conservar su esencial función de principio de deformación, con el suplemento por si fuere poco de un enorme sentido de lo concreto y del detalle naturalista" (Pavis 227).

11 En su escrito "El grotesco como forma escénica" de 1912, Meyerhold recurre a un ejemplo para mostrar cómo la vida puede verse con otra óptica a través de los contrastes: "En un día otoñal, lluvioso, por la calle se alarga un cortejo fúnebre. Por la actitud que adoptan las gentes que marchan tras el féretro, se ve una profunda condolencia; de repente, el viento arranca el sombrero de la cabeza de uno de los apenados acompañantes. Se inclina a recogerlo, pero el viento se lo lleva de una parte a otra. Cada salto del compungido señor tras el sombrero obliga a su cuerpo a contorsiones tan cómicas, que una mano diabólica transforma de repente el tétrico cortejo fúnebre en multitud festiva. ¡Ojala pudiésemos lograr este efecto sobre el escenario! Contraste" (Meyerhold: Textos Teóricos 195). 
El efecto de ilusión de la vida cotidiana buscado por Stanislavski, y el efecto de ficción de la vida cotidiana de Meyerhold, muestran, desde el punto de vista de los resultados, una oposición; sin embargo, desde el punto de vista pre-expresivo no representan objetivos tan opuestos: la técnica extracotidiana se hace visible en uno y otro caso, así parta de la inculturación, o bien, del sentido aculturado.

\section{Pre-expresividad biomecánica}

Para alcanzar esta cotidianidad grotesca o "realismo estilizado", Meyerhold, en 1914, empieza a trabajar el cuerpo a nivel pre-expresivo: " ¿Cómo debe moverse el actor en escena, cómo debe incidir aquel 'dibujo de movimientos' que concretan la relación actor-espectador a nivel sensorial, antes que a nivel intelectual y emotivo?" (Barba y Savarese 180).

Con este programa de estudio, ${ }^{12}$ que en 1922 presenta sus resultados más recientes, Meyerhold hace el tránsito del "teatro de convención consciente" al método de la biomecánica, la cual fue definida así: "La ley fundamental de la biomecánica es muy sencilla: el cuerpo entero participa en cada uno de nuestros movimientos. A continuación, no hay que hacer más que realizar estudios y una serie de ejercicios de perfeccionamiento" (Meyerhold, El actor sobre la escena 111).

Este interés por individualizar y perfeccionar el movimiento es extrapolado al comportamiento cotidiano de los obreros en su trabajo:

Examinando el trabajo de un obrero experto, encontramos en sus movimientos: 1) ausencia de desplazamientos superfluos, improductivos; 2) ritmo; 3) determinación del centro justo de gravedad del propio cuerpo; 4) resistencia. Los movimientos fundados sobre estas bases se distinguen por su carácter de 'danza'; el trabajo de un obrero experto recuerda siempre a la danza, y en este punto bordea los límites del arte (Meyerhold, Meyerhold: Textos Teóricos 230).

Meyerhold plantea que la técnica que utiliza un obrero en su trabajo habitual ha sido perfeccionada por medio de la disciplina y la repetición en el tiempo, a través de lo cual deviene un experto, generando una "segunda técnica" distinta a la cotidiana. También nosotros somos expertos en la esfera del comportamiento cotidiano, como implicaba el antropólogo

12 Aparte de la técnica en movimiento que se daba en su programa de estudio, Meyerhold hizo estudiar a sus actores Commedia dell'Arte, teatro de los siglos XVIII y xIX, teatro oriental, circo, danza, música, así como deportes como atletismo ligero, esgrima, tenis, lanzamiento de disco y navegación a vela. 
Marcel Mauss ${ }^{13}$ al hablar de las técnicas del cuerpo. Sin embargo, lo que le interesa a Meyerhold es el proceso físico por el que pasa un obrero para volverse experto en su ocupación; ahí encuentra la justificación para dar a entender que el trabajo del actor también está condicionado por el adiestramiento de sus bases materiales. El cuerpo del intérprete debe tener la capacidad de utilizar de forma correcta sus medios expresivos, es decir, adquirir una "segunda técnica" que le permita instantáneamente ejecutar las órdenes del director y del autor sobre su biomecánica:

El actor comprende en sí mismo tanto a quien organiza como a lo que debe ser organizado (es decir, el artista es el material). La fórmula del actor consistirá en la siguiente expresión: $\mathrm{N}=\mathrm{A} 1+\mathrm{A} 2$, siendo $\mathrm{N}$ el actor, A1 el constructor -que formula mentalmente y transmite las órdenes para la realización de la tarea-, y A2 el cuerpo del actor, el ejecutor que realiza la idea del constructor A1 (ibídem).

Lo interesante de la cita anterior es constatar la urgencia, por parte de Meyerhold, de darle a sus estudios experimentales una base científica, inspirado en el sistema del taylorismo ${ }^{14}$ de Frederick Winslow, la reflexología ${ }^{15}$ de Iván Petrovich Pavlov y la teoría de la emoción ${ }^{16}$ de James-Lange. Meyerhold no sólo refiere al camino físico inconsciente, sino que se inte-

13 "Hablo de técnicas corporales porque se puede hacer la teoría de la técnica de los cuerpos partiendo de un estudio, de una exposición, de una simple y pura descripción de las técnicas corporales. Con esa palabra quiero expresar la forma en que los hombres, sociedad por sociedad, hacen uso de su cuerpo en una forma tradicional" (Mauss 337).

14 El taylorismo fue un método de organización del trabajo creado por el ingeniero Frederick Winslow Taylor (1856-1915), con la intención de aumentar la productividad por medio de la máxima división de tareas, en las cuales cada trabajador se especializa y así controla estrictamente el tiempo para la realización de dicha tarea. Meyerhold encontró en estos movimientos especializados una economía del cuerpo que se plasmaban como movimientos rítmicos y fluidos, que permiten tener control sobre el cuerpo; eso mismo es lo que le interesa a la biomecánica.

15 La reflexología de Iván Petrovich Pavlov (1949-1936) es el nombre dado a su escuela de psicología en Rusia. Los estudios de esta escuela tienen una estrecha relación con los procesos fisiológicos; en síntesis, reducen los procesos mentales y psicológicos a procesos fisiológicos, proponiendo un orden diferente de intervención en el cuerpo-mente.

16 Conocida como la teoría de James-Lange -ya que la formulación de las hipótesis de William James y Carl Lang se produjeron en la misma época con resultados similares-, ésta interpreta que, provocando una determinada reacción fisiológica, se produce también una emoción. Ejemplo: el circuito estímulo - cambios fisiológicos - corteza cerebral - emoción. Esta forma diferente de intervenir en el cuerpo-mente, también le dio a Meyerhold un impulso para focalizar aspectos físicos que repercuten en los mentales. 
resa también por los aspectos psicológicos o mentales que, para él, pueden ser estudiados por medio de las leyes de la mecánica.

El punto de partida de su trabajo, a diferencia de Stanislavski, consistía en comenzar por el exterior para luego conectar con el interior: no río porque tenga alegría, sino que tengo alegría porque río. Según Picon-Vallin, ${ }^{17}$ en la biomecánica de Meyerhold:

Todo acto físico se pone en marcha por un proceso nervioso, y toda acción puede tener por respuesta una excitación. El proceso que une la excitación a una respuesta de movimiento es un proceso nervioso, por tanto psicológico; el comportamiento humano es visto como una serie de reflejos naturales y condicionados, pues el sistema nervioso responde en todo momento a las oscilaciones-excitaciones del mundo exterior o de su cuerpo mismo (Picon-Vallin, Meyerhold 106).

Aquí, cada acción hace partícipe al cuerpo entero, mientras que en la técnica cotidiana sólo una parte del cuerpo participa. Recordemos que esta última trabaja por la ley del mínimo esfuerzo, mientras que en las técnicas extracotidianas pasa lo contrario: los ejercicios que realiza un actor biomecánico están destinados para quien hace teatro y no para el punto de vista de los espectadores; trabajan en el nivel pre-expresivo y no se restringen a presupuestos físicos, sino también a una forma de pensar en movimiento.

\section{Otkas, posyl, tormos y stoika: acción biomecánica extracotidiana aculturada}

Según Borja Ruiz, el actor biomecánico sintetiza su interpretación en una partitura de movimiento, que incorpora tanto aspectos internos como externos con una particular matización en cada caso: "En la biomecánica, esta partitura, esta mecánica, por muy establecida que esté, debe cobrar vida, debe jugarse, hacerse flexible, de otro modo la interpretación queda vacía, predecible, robotizada" (125).

Meyerhold trabaja la partitura de acción a través de una aculturización del cuerpo, una codificación que el actor compone en cuatro fases: otkas, posyl, tormos y stoika. Éstas visualizan principios recurrentes en las leyes ${ }^{18}$ pre-expresivas de la antropología teatral de Eugenio Barba.

17 Beatrice Picon-Vallin es una de las mayores especialistas sobre Vsevolod Meyerhold. Ha traducido la obra completa del autor y trabaja en el laboratorio de investigación en las Artes Escénica (Centre National de la Recherche Scientifique) de París.

18 Según Barba, entre los principios recurrentes que pueden encontrarse a través de diferentes tradiciones 
El otkas ${ }^{19}$ es un principio de la biomecánica, donde cada acción que realiza un actor debe estar antecedida por un movimiento en la dirección contraria; es el ante-impulso que prepara al ejecutante para realizar una determinada acción: inclinarse para brincar, girar hacia la derecha para ir hacia la izquierda, desplazarse hacia atrás para ir hacia delante, etcétera. Barba utiliza este concepto de Meyerhold para referirse a la ley de oposición; ${ }^{20}$ el actor ocupa en este caso una técnica extracotidiana estilizada, donde se hace visible la complejidad del diseño.

A su vez, el otkas (rechazo) es el ante-impulso para ejecutar la acción principal llamada posyl ${ }^{21}$ (envío), la cual permite dibujar con el cuerpo la trayectoria de la acción en el espacio, finalizando controladamente a través del $\operatorname{tormos}^{22}$ (freno). Una vez finalizada la acción, el tormos puede dar pie a que el siguiente movimiento se convierta, ya sea en un nuevo otkas o ante-impulso, o bien en una stoika $a^{23}$ (retención), en donde la energía de la acción queda en contención dinámica. En la antropología teatral se diría que la acción tiene sat.

Este sistema de Meyerhold considera múltiples ciclos otkas-posyl-tormos-stoika, los cuales permiten transitar a nuevas acciones y constituyen "la sístole y diástole que mantiene el pulso rítmico de las acciones del actor biomecánico" (Ruiz 127).

escénicas de Oriente y Occidente, se encuentran tres leyes: la alteración del equilibrio, la oposición, y la ley de la no-coherencia coherente.

19 Palabra rusa que significa "rechazo". Según Picon-Vallin, el concepto de otkas es esencial en la biomecánica: "Enunciado en 1914 en el estudio de San Petersburgo, es contemporáneamente definido como un elemento de segmentación de la línea principal de la acción (separación respecto al movimiento precedente [...]) y como un movimiento en contrasentido, que se opone a la dirección del movimiento [...]" (Picon-Vallin, Il lavoro dell'attore 104-105).

20 En la ley de la oposición, el actor activa todo su sistema interno de percepción por medio de movimientos sinuosos, nuevas tensiones se hacen latentes. Barba afirma que la danza de las oposiciones se baila en el cuerpo, antes que con el cuerpo.

21 Palabra rusa que significa "enviar". Según Borja Ruiz, el concepto de posyl "en la biomecánica de Meyerhold, es la acción propiamente dicha, que viene precedida por un ante impulso" (127).

22 Palabra rusa que significa "freno": "en la biomecánica de Meyerhold es la parte final en la ejecución de una acción, donde el impulso que lleva se amortigua hasta llegar a una parada" (ibídem).

23 Palabra rusa que significa "retener": "en la biomecánica de Meyerhold describe la parada con la que finaliza una acción” (ibídem). 


\section{Études biomecánicos aculturados}

El ciclo otkas-posyl-tormos-stoika le permite al actor biomecánico no sólo conocer la "economía" de la dinámica de su cuerpo, sino que además es el principio que da forma a las rutinas de ejercicios de mayor complejidad, llamadas études. En ese nivel, la dramaturgia actoral se complejiza aún más, manteniendo presente el trabajo psicofísico. El trabajo mental constituye la manera de estilizar una realidad ya establecida: se apropia de ciertas técnicas cotidianas que, a su vez, al quedar estilizadas, se transforman en técnicas extracotidianas aculturadas.

Según Picon-Vallin, estos ejercicios creados por Meyerhold fueron extraídos de temáticas de la Commedia dell'Arte, el circo, el teatro oriental, la gimnasia, así como de situaciones de la vida cotidiana. Una vez más, Meyerhold encuentra principios recurrentes en otras disciplinas y tradiciones teatrales para extrapolarlos a su propio trabajo, mientras que la lista completa de los 22 études permite constatar que la vida cotidiana es también un motor en la biomecánica:

1. Tiro con arco.

2. Salto sobre la espalda de un compañero y transporte de la carga.

3. Caer, atrapar y lanzar una piedra.

4. Golpe de puñal.

5. La bofetada.

6. Dar la vuelta con la pierna inclinada y de rodillas de un compañero.

7. Juego de los bastones.

8. Lanzar un balón al aire.

9. Lanzar una piedra.

10. Saltar sobre el pecho del compañero.

11. Juego con puñal corto.

12. La cuadrícula.

13. La cuerda.

14. Los caballos.

15. El patinador.

16. Tropezar.

17. El puente.

18. La sierra.

19. La falta.

20. Funerales.

21. El payaso.

22. Salto del cordero" (Picon-Vallin, Meyerhold 111). 


\section{Étude del tiro con arco: principio de equivalencia extracotidiano}

De los 22 études enumerados, se escoge el primero para ser analizado. La acción de tirar una flecha con un arco permite constatar que el actor biomecánico tenía muy presente en su trabajo a la vida cotidiana. Como veremos, Meyerhold estiliza una técnica cotidiana por medio de lo que -en la antropología teatral- se denomina "principio de equivalencia,, será formulado por Barba a partir, precisamente, del trabajo de los grandes reformadores del teatro (especialmente el propio Meyerhold y Stanislavski).

Todos los études (ejercicios) en la biomecánica, empiezan y terminan de una misma forma mediante el dáctilo, que permite marcar el ritmo y tono muscular para el trabajo, poniendo al actor en un estado de preparación física y mental:

a. Se empieza erguido, con los pies paralelos manteniendo una separación igual a la de las caderas y con el peso igualmente distribuido en ambas piernas.

b. Se traslada el peso hacia adelante.

c. A continuación se flexionan las rodillas, originando el impulso.

d. Este impulso se transmite por toda la columna vertebral y por los brazos que, en consecuencia, se levantan.

e. Cuando, siguiendo el impulso que ahora va a favor de la gravedad, éstos se dirigen hacia el suelo, se dan dos palmadas enérgicas: la primera más lenta y amplia, y la segunda más rápida y reducida. Para esta segunda palmada, se vuelve a tomar impulso, tal y como se había hecho previamente pero de forma menos expansiva.

f. El ejercicio finaliza en la misma posición del inicio". (Ruiz 128)

Una vez realizado el dáctilo, el actor pasa a realizar los études ${ }^{25}$ en este caso el de tiro con arco:

24 Con las equivalencias, Barba no pretende radicalizar la oposición entre el cuerpo cotidiano y el cuerpo en representación, sino demostrar cómo ese cuerpo cotidiano es reelaborado, creando tales equivalencias con fines poéticos, es decir, de "representación" y no de mera "presentación".

25 Para realizar los études, Meyerhold tenía muy presente la importancia de la música. En el caso del ejercicio de tiro con arco, utilizaba el Estudio Op. 12 en C menor de Fréderic Chopin. La música le serviría al actor para mantener el ritmo y poder jugar (desde el punto de vista exterior), así como para mantener una intención interior. "Para Meyerhold, el diseño de los movimientos es la condición sine qua non para ser actor. Meyerhold indaga los criterios de esta condición a lo largo de toda su carrera. Le da siempre más autonomía en relación al trabajo sobre el texto, modelando la partitura ya no con el instrumento del pensamiento dramatúrgico, sino a través del saber musical. Su lengua de trabajo está constituida por la terminología musical y por palabras como 'ritmo', 'danza, 'biomecánica, que sustituirán a 'interpretación' y 'perezhivanie"' (Barba, La canoa de papel 195). 
1. El actor realiza dos dáctilos (se marca el ritmo y tono muscular para realizar la acción equivalente a tirar con un arco).

2. Señalando con el brazo hacia abajo, indica que se ha encontrado un arco (ya desde un principio la imaginación toma una parte importante en el étude).

3. Dobla las rodillas lentamente, manteniendo el torso vertical con sus brazos a los lados.

4. Cae al suelo para recoger el arco imaginario.

5. Vuelve a la posición 3 .

6. Sube lentamente, manteniendo el torso recto hasta estar totalmente de pie.

7. Con el brazo izquierdo, señala y observa que hay una presa imaginaria.

8. Realiza una acción de sigilo, contrayendo el cuerpo.

9. Indica, en principio, la acción de utilizar el arco.

10. Realiza un semicírculo con el brazo derecho.

11. Cambia rápido el peso, de nuevo a una posición horizontal, manteniendo el arco.

12. Empieza a estirar la cuerda, lentamente, buscando una tensión.

13. Transfiere el peso a la pierna derecha, extendiendo horizontalmente los brazos con la imagen de estirar un arco y dispara.

14. Vuelve a la posición 12.

15. Toma impulso, buscando una oposición.

16. Voltea y levanta rápidamente ambos brazos hacia arriba, cabeza también arriba, peso sobre el pie izquierdo y lomo arqueado.

17. Realiza el disparo, que incluye un salto hacia arriba.

18. Vuelve nuevamente a la posición inicial y realiza nuevamente un dáctilo.

Al partir de una acción cotidiana y convertirla en una danza muy precisa, Meyerhold estaría utilizando en este étude el principio de equivalencia. Su trabajo pre-expresivo le permite al actor tener conciencia de su cuerpo y dominarlo a través del ciclo de otkas, posyl, tormos, stoika. En definitiva, en esta secuencia se llevan a cabo, mediante una especie de danza, transferencias de peso que involucran un equilibrio precario, motivando así a que la imagen tenga en todo momento un ritmo fluido. Según Barba:

[...] a través de este ejercicio, el alumno comenzaba a comprender por sí mismo, en términos de espacio, cómo adquirir autocontrol físico, desarrollaba elasticidad y equilibrio; se daba cuenta de que el mínimo gesto resonaba a través del cuerpo entero; practicaba el así llamado rechazo (otkas). En este ejercicio el rechazo, es decir, lo que viene antes que el gesto, es la mano que toma la flecha detrás de la espalda. El ejercicio es un ejemplo de una secuencia de acciones que comprende intención, realización y reacción (Barba y Savarese 151). 


\section{Meyerhold intercultural y la antropología teatral}

Gracias a sus precursores, la antropología teatral deriva de otras tradiciones interpretativas del Oriente (de rasgos estilizados) indicaciones útiles para el actor. El trabajo preciso y de carácter intensamente corporal y técnico de tales tradiciones motivó a nuestros maestros a indagar en los principios recurrentes a través de ellas. Desde Meyerhold con el teatro japonés, Antonin Artaud con las danzas balinesas, Beltrot Brecth con el teatro chino, y Grotowski en la India el ver más allá de Occidente ha sido una constante durante el último siglo.

En el desarrollo de su propuesta, Meyerhold llevó a cabo un viaje transcultural, recurriendo tanto a referencias orientales (como el kabuki, el nô, la Ópera de Pekín), como occidentales (Commedia dell'Arte y circo, por ejemplo). Así, encuentra unos principios que retornan, constituyendo claves para que el actor sepa cómo moverse en el escenario. La danza, por ejemplo, ya no es un arte separado del teatro, sino un modo de intervenir dentro del mismo.

En la misma línea, Barba recurre a autores que se dirigen a Oriente para encontrar principios recurrentes en sus respectivas técnicas teatrales, desarrollando una nueva visión que sintetizaría posteriormente en su antropología teatral. Tal vez sea Meyerhold el autor con quien más se identifica: "Jerzy Grotowski, Eugenio Barba, y en algún sentido también Peter Brook, aparecen como el punto de llegada de la tradición que ha sido llamada de los 'directores pedagogos', según la expresión acuñada por Meyerhold” (De Marinis 14).

Meyerhold no se preocupó solamente por la técnica teatral, sino que, en su interés por encontrar esos principios que retornan, propuso el concepto de escenología, en alusión a la ciencia y teoría de la puesta en escena. Se trataría de una ciencia que abarca todos los elementos involucrados en la creación de una puesta en escena (dramaturgia, dirección, actuación y escenografía), como lo hace actualmente también la llamada etnoescenología. ${ }^{26}$

Específicamente en el nivel que precede al drama, como se ha visto, Meyerhold alude a algunos elementos que pueden entenderse mejor con la ayuda de la antropología teatral de Eugenio Barba (posturas inestables, equilibrio y desequilibrio, ley de los contrarios, energía que danza, técnica cotidiana, técnica extracotidiana, aculturación, principios de equivalencia). A su vez, Barba reconoce que: "Los principios del grotesco, es decir, la biomecánica, no fueron suposiciones fortuitas, sino la ingeniosa interpretación de los mismos principios que hoy, a la luz de la antropología teatral, reencontramos en la base del nivel pre-expresivo del actor" (Barba y Savarese 180).

26 La etnoescenología promueve el estudio de las prácticas espectaculares en el mundo entero, tal como lo propone también la antropología teatral, desligándose del etnocentrismo que el teatro europeo tiene como criterio de análisis de otras prácticas espectaculares, ajenas a su cultura. 


\section{Recapitulación y conclusiones}

- El interés de Meyerhold por la plástica y la estilización de la realidad le llevaron a concebir un nuevo teatro de "convención consciente", que en su concepto podía remediar la indisciplina actoral del teatro naturalista, promoviendo la disciplina en un "realismo convencional".

- El grotesco le permitió a Meyerhold aproximarse de forma insólita a la vida cotidiana. La técnica cotidiana se transforma aquí por medio de la exploración de los contrarios, la cual pone en escena un contraste que implica una estilización de la realidad, llevando al espectador a resolver "el enigma de lo incomprensible".

- La biomecánica le permitió al actor adiestrar sus bases materiales por medio de una sinuosa técnica extracotidiana aculturada, tanto en aspectos físicos como psicológicos. Los aspectos mentales son estudiados desde las leyes de la mecánica, donde toda acción hace partícipe al cuerpo entero.

- La partitura mecánica otkas-posyl-tormos-stoika, permitió al actor conocer, controlar y utilizar su cuerpo con una dinámica "económica" (expresada en la fórmula $N=A 1+$ $A 2)$. Desde el punto de vista expresivo, el actor pudo desarrollar con ello una "segunda técnica", diferente a la cotidiana, para poder ejecutar instantáneamente las órdenes del director y del autor. Es por ello -y no porque se implique un menor gasto de energía-, por lo que se habla de "economía".

- Las rutinas de ejercicios llamadas études constatan, desde el punto de vista de nuestra investigación, que Meyerhold estilizó la técnica cotidiana por medio del principio de equivalencia de la antropología teatral. Esta manera de intervenir, indica el camino pre-expresivo de aculturación implicado en la biomecánica.

- La antropología teatral de Eugenio Barba se nutrió de Meyerhold, según lo muestran las siguientes equivalencias conceptuales:

- Equilibrio y desequilibrio = biomecánica.

- Ley de oposiciones = otkas.

- Sat (impulso, energía que danza) $=$ posyl.

- Ley de la omisión = tormos y stoika.

- Técnica cotidiana = convención consciente.

- Técnica extracotidiana aculturada = biomecánica.

- Principios de equivalencia = études y grotesco.

- Principios que retornan $=K a b u k i$, Nô, ópera de Pekín (oriente), + gimnasia, $b a$ llet, Commedia dell'Arte, circo (occidente).

- Pre-expresividad = biomecánica.

- Antropología teatral = escenología. 
Los principios técnicos que visualizó Meyerhold permiten constatar y contrastar los principios que hoy en día se trabajan desde el punto de vista de la antropología teatral, mostrando que el maestro ruso, por medio de una codificación específica del cuerpo (biomecánica), fue capaz de derivar las emociones como un desenlace del flujo externo del movimiento. Se trata de una particular manera de intervenir en la unidad psicosomática del actor, característica de la técnica extracotidiana aculturada.

\section{Bibliografía}

Barba, Eugenio y Nicola Savarese. El arte secreto del actor. $4^{\text {a }}$ ed. Traducido por Raúl Iza, et al. Lima: San Marcos, 2010.

Barba, Eugenio. La canoa de papel. Tratado de Antropología Teatral. Traducido por Rina Skeel. Buenos Aires: Catálogos Editora, 1994.

Barba, Eugenio. "La conferencia de Santiago (Lecture on Theatre Anthropology Given in Santiago, December 1988)". Apuntes de Teatro, núm. 99, 1988, pp. 87-95.

Barba, Eugenio. Más allá de las islas flotantes. Traducido por Toni Cots. Ciudad de México, México: Escenología A.C., 1986.

Craig, Gordon. El arte del teatro. Traducido por M. Margherita Pavía. Ciudad de México: Grupo Editorial Gaceta, 1987.

De Marinis, Marco. La parábola de Grotowski: el secreto del 'novecento' teatral. Traducido por Silvina Diaz, Claudia y Adriana Castagnini. Buenos Aires: Editorial Galerna, 2004.

De Toro, Fernando. Semiótica y teatro latinoamericano. Buenos Aires: Grupo Editorial Galerna / Instituto Internacional de Teoría y Crítica de Teatro Latinoamericano, 1990.

Law, Alma y Mel Gordon. Meyerhold, Eisenstein and Biomechanics: Actor Training in Revolutionary Russia. North Carolina: McFarland, 1996.

Leach, Robert. "Meyerhold and Biomechanics". Actor Training, editado por Alison Hodge. $2^{\mathrm{a}}$ ed. London: Taylor \& Francis e-Library, 2010, pp. 26-42.

Mauss, Marcel. Sociología y antropología. Traducido por Teresa Rubio y Martín Retortillo. Madrid: Editorial Técnos, 1979.

Meyerhold, Vsévolod. Teoría teatral. $9^{a}$ ed. Traducido por Agustín Barreno. Madrid: Editorial Fundamentos, 2013.

Meyerhold, Vsévolod. El actor sobre la escena. $5^{\text {a }}$ ed. Traducido por Enriqueta Bernal López, Noemí Lucero Castillo y Margherita Pavia. Ciudad de México: Escenología, A.C., 2005.

Meyerhold, Vsévolod. Écrits sur le théâtre, tome 1. 9a ed. Traducido por Béatrice Picon-Vallin. Lausana: Editions L'Age D’Homme, 2001. 
Meyerhold, Vsévolod. Meyerhold: Textos teóricos. 2a ed. Traducido por J. Delgado, et al. Madrid: Publicaciones de la Asociación de Directores de Escena de España, 1992.

Pavis, Patrice. Diccionario del teatro: dramaturgia, estética, semiología. Traducido por Jaume Melendres. Buenos Aires: Paidós, 2008.

Picon-Vallin, Béatrice. Meyerhold. Paris: Centre National de la Recherche Scientifique, 1990.

Picon-Vallin, Béatrice. "Il lavoro dell'attore in Mejerchol'd. studi e materiali". Revista Teatro e Storia, vol. 18, 1996, pp. 85-140.

Ruiz, Borja. El arte del actor en el siglo XX. Un recorrido teórico y práctico por las vanguardias. Bilbao: Artezblai S.L., 2008.

Sperber, Dan. El simbolismo en general. Traducido por J.M. García de la Mora. Barcelona: Editorial Anthropos, 1978.

Tolmacheva, Galina. Creadores del teatro moderno. Ciudad de México: Escenología A.C., 2011.

Vallejo, Patricio. Teatro y vida cotidiana. Quito: Universidad Andina Simón Bolívar, Sede Ecuador / Corporación Editora Nacional / Ediciones Abya Yala, 2003.

Watson, Ian. Hacia un tercer teatro. Traducido por Susana Epstein. Ciudad Real: Ñaque Editora, 2000. 


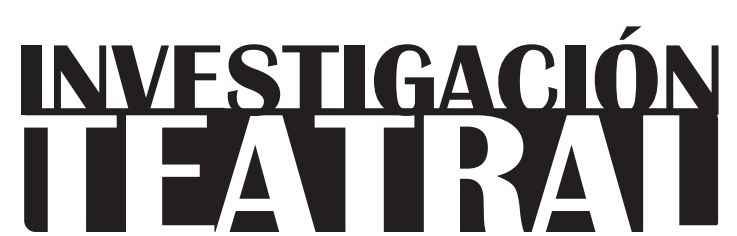

Revista de artes escénicas y performatividad

Vol. 10, Núm. 15

abril-septiembre 2019

Segunda época

Testimonio:

ISSN impreso: 1665-8728

ISSN electrónico: 2594-0953

Universidad Veracruzana

El canto vivo en el trabajo del actor. Taller con el Workcenter de

\title{
Jerzy Grotowski y Thomas Richards
}

\author{
Carlos Albarrán*
}

\author{
* Maestría en Artes Escénicas, \\ Universidad Veracruzana, México. \\ e-mail: carlos.albarran12@gmail.com
}

Recibido: 22 de septiembre de 2018

Aceptado: 21 de febrero de 2019 


\section{El canto vivo en el trabajo del actor. Taller con el Workcenter de Jerzy Grotowski y Thomas Richards}

\section{Resumen}

El Workcenter de Jerzy Grotowski y Thomas Richards representa una continuación en las investigaciones del maestro Jerzy Grotowski en su última etapa, centrada en la indagación vibratoria de los cantos provenientes de tradiciones ancestrales. Actualmente, el Workcenter ha vuelto a la creación de puestas en escena, donde el trabajo vocal cobra una importancia en la actuación teatral. El presente testimonio se centra en un taller que el Workcenter impartió, por primera vez, en la Ciudad de México, donde el autor enfoca su atención en la experiencia del trabajo con la voz e intenta brindar un contexto general sobre las aportaciones del Workcenter hacia los estudios de voz en las artes escénicas.

Palabras clave: Grotowski, voz, vibraciones, canto vivo, trabajo actoral.

\section{The Living Song in the Actor's Work. A Workshop with the Workcenter of Jerzy Grotowski and Thomas Richards}

\section{Abstract}

The Workcenter of Jerzy Grotowski and Thomas Richards continues Grotowski's last period of research, which focuses on the vibratory inquiry of songs from ancestral traditions. Currently, the Workcenter has returned to the creation of staged performances, where vocal work takes on an important role in acting. This testimony refers to a Workcenter workshop offered for the first time in Mexico City. The author focuses on the voice work experience, and attempts to provide a general context about the Workcenter contributions to voice studies in the performing arts.

Keywords: Grotowski, voice, vibrations, living song, acting work. 


\section{El canto vivo en el trabajo del actor. Taller con el Workcenter de Jerzy Grotowski y Thomas Richards}

\section{Primer encuentro en México con el Workcenter}

$\mathrm{E}$ towski en Pontedera, Italia. Su primera parada fue el Festival Cultural Zacatecas, donde se realizó una conferencia, talleres y dos funciones de las puestas en escena The Living Room ${ }^{2}$ y Gravedad, dirigidas por Thomas Richards, a quien Grotowski nombró para dar continuidad a su trabajo, tras su fallecimiento, en $1999 .^{3}$

1 Este lugar fue fundado en 1986; ahí, durante 13 años, Jerzy Grotowski realizó investigaciones sobre "El arte como vehículo". Thomas Richards es el heredero de su trabajo y el actual director del Workcenter, en asociación con Mario Biagini, su más cercano colaborador. Actualmente, el Workcenter está integrado por 18 artistas de nueve países, según indica el sitio oficial: www.theworkcenter.org/brief-history/

2 Esta puesta en escena está integrada por los miembros del Workcenter, quienes están enfocados en la investigación de "el arte como vehículo" (Focused Research Team in Art as Vehicle). Este equipo sólo se presentó en Zacatecas.

3 Richards estudió Música y Estudios Teatrales en la Universidad de Yale (Estados Unidos); cuenta con un doctorado por la Universidad de París viII, en la disciplina de Arte, Teatro y Estudios de Danza, y una maestría en Arte, Música y Performance por la Universidad de Bolonia (Italia). Es director artístico del Workcenter y autor del libro Trabajar con Grotowski sobre las acciones físicas. Para más información, véase: www.theworkcenter.org/about-the-workcenter/two-teams/workcenter-members-2/ 


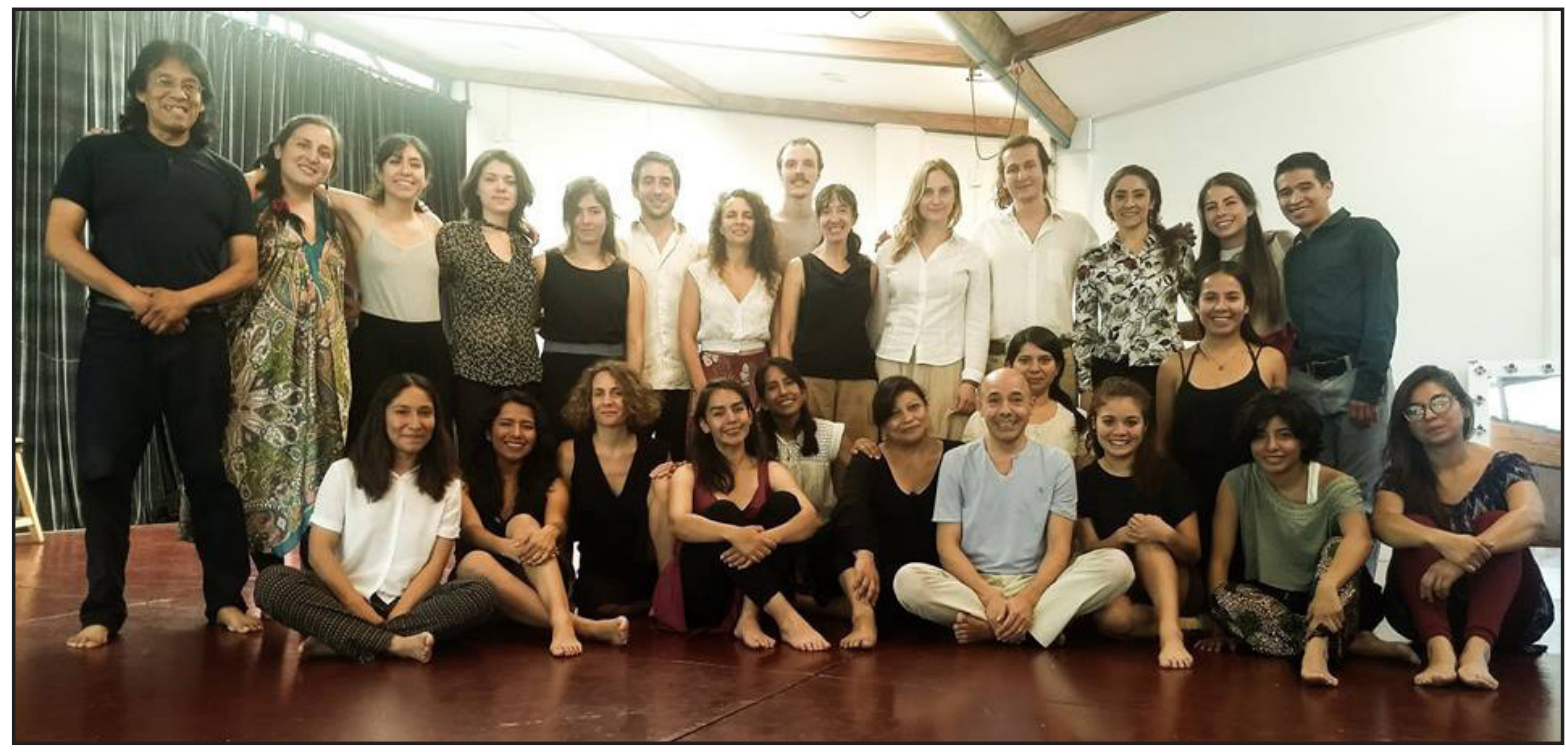

Foto del taller. Miércoles 18 de abril. Jaime Soriano, Thomas Richards y el Workcenter Studio in Residence. Ciudad de México, 2018. Fotografía de Jaime Soriano / Laboratorio de Artes Escénicas Jerzy Grotowski-México.

La Ciudad de México fue el segundo sitio que visitaron los integrantes del Workcenter in Residence. ${ }^{4}$ La estancia en esa metrópoli fue organizada por Jaime Soriano, quien ha sido uno de los principales continuadores del legado de Grotowski en México, a través de su trabajo como actor, director de escena y pedagogo, labores que realiza por medio del Laboratorio de Artes Escénicas Jerzy Grotowski-México (LArtEs) que dirige desde 1986. LArtEs fue el principal coordinador de las actividades del Workcenter, bajo un programa titulado Primer encuentro académico y artístico con el Workcenter of Jerzy Grotowski and Thomas Richards/Toscana-CDMX 2018, "El Actor como creador escénico”. Durante éste se realizaron dos talleres de "El canto vivo en el trabajo del actor". Asistí al primero y es de ahí de donde nace el presente testimonio.

4 Es un equipo creado en 2016, por Richards, con el objetivo de reorientar el proceso pedagógico de aquellos que han asistido constantemente a los talleres. Su fin es profundizar en sus aprendizajes a través de dos puestas en escena, de las cuales Gravedad y Sin Fronteras son resultado de este proceso. Más información en: www.theworkcenter.org/workcenter-studio-in-residence/

5 El primero fue de 17 al 19 de abril, de diez de la mañana a una de la tarde; el segundo del 24 al 26 de abril en el mismo horario. Ambos se realizaron en las instalaciones de "La Máquina del Teatro", en Coyoacán. Entre otras actividades, se realizó la conferencia "Treinta años del Workcenter: una retrospectiva", a través de la Cátedra Ingmar Bergman (UNAM), un conversatorio en la Escuela Nacional de Arte Teatral (INBA) y presentaciones de las puestas en escena Gravedad y Sin Fronteras. 
Para empezar, presento un breve repaso sobre la génesis de este trabajo vocal. Sitúo sus antecedentes en las investigaciones de Jerzy Grotowski (1933-1999). Posteriormente, comparto mis impresiones personales sobre el taller, en diálogo con las participantes Mariana Alarcón Solórzano ${ }^{6}$ y Berenice Quirarte Rojas; ${ }^{7}$ además, Soriano me concedió una entrevista que ayudó a orientar mis impresiones. También expongo una somera reflexión sobre el trabajo vocal de las puestas en escena Gravedad y Sin Fronteras, ${ }^{8}$ para finalizar con algunos comentarios adicionales sobre el encuentro.

\section{Breve génesis del canto vivo}

Jerzy Grotowski fue uno de los creadores que, a mediados del siglo pasado, revolucionaron las artes escénicas y el conocimiento sobre el actor. En 1967, su trabajo teatral fue reconocido como "único" por el director de escena Peter Brook, debido a la profundidad de sus investigaciones respecto a la "naturaleza de la actuación" (Grotowski, Hacia un teatro 5). Para entonces, había replanteado las concepciones del actor en torno a su integralidad cuerpo-mente-esencia, dando importancia al trabajo vocal, en una investigación compleja centrada en la persona y su cualidad de acción. Así, la voz fue un tema presente a lo largo de sus diferentes facetas de investigación que pueden dividirse, de acuerdo con Elka Fediuk, "en dos grandes etapas: la producción de espectáculos (1959-1969) y el trabajo parateatral (1970-1999)" (126). El mismo Grotowski llamó "técnica positiva” a su etapa de entrenamiento -entre 1959 y 1962-, en oposición a una búsqueda posterior, que llamó la "vía negativa" (Hacia un teatro 94).

La "técnica positiva" de los ejercicios consistía en la indagación de una adecuada técnica vocal para el actor. Esta etapa se puede revisar en el libro Hacia un teatro pobre (109138) y en el artículo “Técnica de la voz”, publicado en la revista Máscara (182-189). ${ }^{9}$ En este periodo se situaron algunos puntos, que continuaron en sus fases posteriores teatral y parateatral: amplitud de laringe, amplitud vocal en el uso de resonadores, disminución de atención en las consonantes - con prioridad a las vocales-, y el juego e imaginación a favor de la creatividad -en oposición a la mecanización y disección de la palabra-, en el

6 Bailarina, estudia el doctorado en Psicología Educativa en la UNAM.

7 Bailarina, estudia la maestría en Estudios del Arte por la Universidad Iberoamericana.

8 Fueron presentadas en el Foro del Centro Cultural "Los Talleres" de Coyoacán, Ciudad de México.

$9 \quad$ También es incorporada por Fidel Monroy, en su libro Voz para la escena (ver páginas 393-406). 
entrenamiento de la dicción que dotaba de "vida" al discurso oral. ${ }^{10}$ Luego, Grotowski desplazó la intervención del actor en la respiración y priorizó la observación, en contra de toda manipulación o control vocal.

La "vía negativa" hizo que Grotowski se alejara de la búsqueda de un método vocal, para situarse en un trabajo de investigación sobre la autoconsciencia del funcionamiento de la voz, alejado de recetas y preceptivas que bloqueaban la emisión vocal. Observó que, si un actor o cantante concentraba su atención exclusivamente en el aparato vocal, podía lesionarse más fácilmente que quien respondía a sus impulsos orgánico-corporales ("Técnica" 189-193). También encontró mayor espontaneidad y frescura en la gente común: en los cantos de los campesinos o en una mujer que entonaba una melodía mientras realizaba el aseo. En ambos casos, observó una falta de intervención directa sobre el aparato vocal, una reacción orgánica de la respiración y una coordinación de la voz con la acción del cuerpo, contrario a los entrenamientos especializados, que denominaba "deformaciones profesionales", que controlan el funcionamiento de la voz y provocan prejuicios que inhiben la organicidad de la viveza vocal ("Técnica" 190-193).

La cualidad "viva" de la voz se lee como uno de los principales intereses de Grotowski. Esta característica puede definirse como la vía opuesta a los entrenamientos que concentran su atención en los órganos productores de la fonación. La voz "viva" se encuentra en las experiencias del actor, en sus recuerdos y cultura. Ésta puede atravesar el cuerpo por medio de los "resonadores", que amplían el rango vocal gracias a la consciencia de las vibraciones sonoras, que recorren no sólo los huesos, sino también la musculatura en sus sensaciones; luego, se proyectan en el espacio -las paredes, por ejemplo- y retornan a través de la escucha, en forma de eco. La viveza de la voz se gesta por medio de la exploración y el contacto con otras personas, que se crean en las dinámicas corporales y cinéticas por el espacio ("Técnica” 196-201). De esa manera, se libera la voz:

Todo lo que es asociativo y se orienta hacia una dirección en el espacio, todo eso libera la voz. Libera, sobre todo, en los estudios en actuación los impulsos no fríos, pero rebuscados en el campo de nuestro propio recuerdo, de nuestro propio cuerpo-memoria. Eso va a crear la voz ("Técnica” 199).

10 Grotowski decía que la división de las palabras en fonemas provocaba que la pronunciación del actor se asemejara al estudiante de lengua extranjera que aprende a través de un libro, lo que provocaba que la dicción fuera estéril, en comparación a la diversidad de formas del habla que se encuentran en la vida. Promovía que los actores aprendieran a observar las distintas dicciones de las personas, para que modificaran la propia de manera flexible, evitando caer en formas limitantes y unívocas de pronunciación (Hacia un teatro 133-135). 
Para referirse con mayor precisión a la cualidad vibratoria de la voz que despierta el cuerpo-memoria, Grotowski reemplazó el uso de la palabra "resonadores" por "vibradores".11

La sonoridad de las voces y sus cualidades vibratorias estuvieron presentes en sus espectáculos, según reconoció en 1993, tras varios años de investigación. En este tiempo, los cantos tradicionales tomaron un lugar protagónico en su Workcenter (Fediuk, "El cuerpo" 148). La vocalidad se volvió más compleja en sus proposiciones, dado que no se formuló un método, sino que su atención se centró en una investigación constante sobre la voz de la persona en su integralidad, lo que le permitió entender que era imposible realizar un trabajo vocal si no se accedía al acervo del cuerpo-memoria ("Técnica" 199). La llave de acceso fueron las "asociaciones", que despertaban imágenes y sugerencias al actor, promoviendo una pedagogía lúdica que lo involucraba directamente en su propio cuerpo ${ }^{12}$ De ese modo, se liberó del paradigma "técnico"13 de la ejercitación vocal, para favorecer la carnalidad de la actuación: cuando el actor se encuentra vibrando no por medio de la voluntad, sino de una entrega que lo compromete en su cualidad creativa, entretejida en el training, donde no se trabaja "sobre la voz" (ibídem), sino que la creación artística sucede en integración con todo el ser.

A partir de 1969, Grotowski dejó la producción de espectáculos teatrales. Entonces, su atención sobre la voz fuera del teatro tomó su cauce en contacto con la naturaleza y la vivencia personal, lejos de toda ficción teatral. En la etapa de Special Projects, en Brzezinka, "se atravesaba el bosque [...] y, de regreso, durante el aparente descanso, aparecían los cantos, alguien bailaba, pero sin racionalizar las sensaciones" (Fediuk, "El cuerpo" 145). En el documental Acting Therapy, de 1976, las dinámicas de la voz fueron conducidas por Zygmunt Molik, donde se perseguía la apertura de la laringe, las amplias

11 Al mismo tiempo, el término "resonador" fue convencional. Las sensaciones vibratorias o "propioceptivas" son aquellas que se transmiten a través del esqueleto, inundando varias partes del cuerpo (Monroy 71).

12 Grotowski se involucraba corporalmente en las dinámicas vocales, según describió en sus notas Franz Marijnen, en 1966: "Grotowski participa en el ejercicio él mismo. Juega a que es un 'tigre' que ataca a su presa. El alumno (la presa) reacciona rugiendo como un 'tigre' [...]. No sólo es cuestión de rugir. Los sonidos deben apoyarse en el texto [...]. Grotowski dice: "Acérquese... Texto... Grite... Yo soy el 'tigre', no usted... Me lo voy a comer..." (Hacia un teatro 142).

13 "La técnica es siempre mucho más limitada que un acto. La técnica es necesaria solamente para comprender que las posibilidades son infinitas y, después, sólo como conciencia que disciplina y precisa. Fuera de esto, hay que abandonar la técnica. La técnica creadora es lo contrario de la técnica en el sentido corriente de la palabra; es la técnica de aquellos que no caen en el diletantismo y en el plasma; y que cuando menos han abandonado la técnica" (Grotowski, "Técnica" 201). 
vibraciones del cuerpo y el contacto único de la persona con su propia voz (Campo y Molik 1-10), lo que gestó otros proyectos bajo el nombre de "tu canto" o "tu canción" (Fediuk, "El cuerpo" 145).

En la etapa denominada "El teatro de las fuentes" -correspondiente al periodo 19761982- (Prieto 145), ${ }^{14}$ Grotowski realizó una profunda investigación sobre las tradiciones antiguas; buscaba una forma de retornar orgánicamente a formas más primitivas del ser humano, a través de técnicas rituales transculturales. En esa época, se interesó por la cualidad vibratoria de los cantos rituales afrocaribeños (Goiricelaya 90-92).

En 1984, Thomas Richards escuchó, por primera vez, los cantos tradicionales de Haití, en voz de Maud Robart, ${ }^{15}$ en la Universidad de Irvine, California, durante el seminario de Drama Objetivo. Ello lo marcó notablemente y lo hizo incursionar, desde 1985, en el trabajo con Grotowski. Richards describe así su experiencia:

Cuando escuché las canciones de Haití, las canciones tradicionales, estaba escuchando la voz de mi abuela, a quien nunca antes había oído cantar. El linaje de mi abuela, del lado de mi padre, viene del Caribe [...] fue como... tocar en mí algo que realmente nunca había sido tocado hasta ese punto (Heart 2). ${ }^{16}$

El canto fue central en el trabajo que inauguró el Workcenter en 1986, en Pontedera. En ese lugar, Richards fue asistente de Grotowski, tras un periodo de aprendizaje y confrontación consigo mismo, en el proceso de autoconocimiento (Heart 3-10). El "aspecto interno del trabajo", enraizado en los cantos, fue la principal herencia de Grotowski hacia Richards. Este aspecto fue investigado por Grotowski en su última etapa de trabajo, denominada "El arte como vehículo", enfocada en una labor minuciosa de rigor, concentración y detalle sobre los cantos (Grotowski, "De la compañía" 8). Esta escrupulosa atención de los cantos

14 Durante esta etapa, Grotowski viajó a México por invitación del Taller de Investigación Teatral (TIT) de la UNAM, para conocer la cultura huichola, en 1980. Este viaje fue el tercero que realizó a este país. El primero fue en 1968, con la presentación de El príncipe constante; el segundo, en 1977, cuando impartió conferencias en la UNAM y el cuarto, en 1985, donde trabajó con miembros del TIT a cargo de Nicolás Núñez (Prieto 145).

15 Colaboró con Jerzy Grotowski de 1977 a 1993. Fue maestra de Richards y de Jaime Soriano. Ha investigado los cantos de la tradición vudú de su natal Haití y, actualmente, desarrolla investigaciones sobre el canto en una vertiente espiritual, véase: artacartoucherie.com/wiki/artists-and-contributors/maudrobart-spirit-of-singing/

16 Original: "When I heard the songs of Haiti, the traditional songs, it was hearing the voice of my grandmother, whom I'd never before heard sing. My grandmother's line on my father's side came from the Caribbean [...] it was like... touching in me something that had really never been touched up to that point". 
-en su aprendizaje de la melodía y su pronunciación- tuvo, como eje, la afectación de los cuerpos en las vibraciones que conducen a un tipo de "verticalidad" energética:

Verticalidad -el fenómeno es de orden energético: energías pesadas, pero orgánicas (vinculadas a las fuerzas de la vida, a los instintos, a la sensualidad) y otras energías, más sutiles. La cuestión de la verticalidad significa pasar de un nivel digamos toscoen cierta manera podemos decir entre comillas "cotidiano" a un nivel energético más sutil o incluso a la alta conexión (Richards, Trabajar con Grotowski 198).

Esta característica provocada por los cantos vibratorios fue perceptible en las sesiones dirigidas por Thomas Richards durante el taller de la Ciudad de México. A continuación, expondré mi testimonio personal, donde es posible leer, en la narración de las dinámicas, el modo en que la herencia vocal de Grotowski continúa resonando en el "canto vivo" del Workcenter.

\section{Las sesiones de canto}

Fueron tres días llenos de vibraciones acústicas que tocaron los cuerpos de los participantes. En el taller, dirigido por Thomas Richards y su asistente Jessica Losilla Hébrail (Francia), estuvieron presentes los integrantes del Workcenter Studio in Residence: Alonso Abarzúa (Chile-Suecia), Gina Gutiérrez (Colombia), Juan David Salazar (Colombia), Felipe Salazar (Colombia), María Constanza Solarte (Colombia) y Javier Cárcel Hidalgo-Saavedra (España).

La primera sesión se dedicó a mostrarnos los materiales con los que nos involucraríamos en los siguientes días. Al iniciar, Richards mencionó que ese día presenciaríamos los cantos que él trabajaba con su grupo. ${ }^{17}$ Juan David Salazar nos guió en las dinámicas y, aunque algunos debíamos permanecer sentados, teníamos que mantener un estado activo y receptivo. También se requería captar la melodía y pronunciación específica de los cantos, una precisión expuesta por Grotowski.

Juan David Salazar daba escasas indicaciones verbales. Nos invitaba con su cuerpo, tomaba nuestras manos o hacía un gesto a la distancia, manteniéndose alerta del equilibrio en el espacio mediante el constante movimiento de los cuerpos. Cada uno de los actores y actrices sabían cuándo desplazarse, acercarse, tomar a alguien, alejarse, mirar,

17 Las traducciones del inglés al español fueron realizadas por el actor Javier Cárcel Hidalgo-Saavedra. 
sonreír, callar y detenerse. El contacto y la comunicación eran principalmente corporales, lo que creaba una sensación de grupo.

En general, los cantos se basaban en dos estructuras de repetición; una era conducida solamente por el líder del canto, y la otra se cantaba de forma coral. Las dos partes siempre eran cantadas por el líder, quien figuraba como la voz principal. Cada integrante del Workcenter tenía su propio canto y, en ocasiones, había quienes compartían la misma canción. Los idiomas y referencias culturales eran tan diversos como las nacionalidades de los integrantes. ${ }^{18}$ El canto se repetía varias veces, siempre de manera distinta; no en la precisión de las palabras o melodías, sino en su capacidad vibratoria y de afectación al cuerpo del cantante-líder. El canto parecía cobrar vida autónoma y se apropiaba del cuerpo de la persona, en un estado semejante a la posesión. Grotowski explicó este tipo de proceso:

Cuando se comienzan a captar las cualidades vibratorias a través de un gran rigor artesanal, todo esto encuentra su arraigamiento en los impulsos y las acciones. Y entonces, de golpe, ese canto empieza a cantarnos. Ese canto antiguo me canta, ya no sé si soy ese canto o si descubro ese canto. Cuidado, ¡cuidado! Es el momento donde hay que tener vigilancia, no volverse la propiedad del canto, sí, "estar de pie" ("De la compañía" 11).

Thomas Richards ofreció una conferencia en la UNAM. Ahí mencionó que el canto se trataba de una acción continua, que provocaba que se entrara en ese "otro estado", que a él no le gustaba mencionar que fuera de "trance", aunque así pareciera a los ojos de otros. Ese estado energético se trataba de un presente total en donde sólo se estaba completamente en la acción del canto que generaba la cualidad extraordinaria sustentada en la "verticalidad" ("Treinta años").

El final de la primera sesión consistió en formar pequeños grupos, donde los integrantes del Workcenter nos transmitieron un par de canciones. Procuraban que cada uno liderara una canción y que los otros hiciéramos el coro. Jessica Losilla Hébrail y Juan David Salazar orientaron el grupo donde me encontraba. El proceso se basó en aprender con exactitud la letra, la melodía y el ritmo, sin entrar en una dinámica de movimiento por el espacio. Jessica solicitaba que, aun en el cuidado de la precisión técnica, el cuerpo energizado se mantuviera presente y alerta, para evitar caer en monotonías mecanizadas.

El segundo día, con Richards, repasamos los cantos de manera grupal, en atención a una precisión generalizada. Eso fue con el fin de que algunos pudiéramos dirigir una can-

18 Se podían distinguir canciones afrocaribeñas y surgidas de las tradiciones ancestrales latinoamericanas; es el caso de los miembros de Colombia, por ejemplo. 
ción y que todo el grupo se involucrara en los coros y movimientos por el espacio, esta vez sin la ayuda de Juan David. Desde entonces nos hicimos cargo de nuestra distribución en el espacio, de la distancia y el contacto, aunque siempre contamos con las miradas alertas de los integrantes del Workcenter, que ofrecían su apoyo en la cercanía-lejanía.

Por medio de la imagen de una fogata, Richards ejemplificó la paradoja del contacto y la cercanía. Dijo que, quien lideraba la canción, representaba al fuego. Podíamos estar muy cerca, aunque sincrónicamente esto podía hacer que estuviéramos lejos; de manera inversa, se podía estar alejado y con el deseo de estar cerca. El contacto se establecía también a la distancia, haciendo que la piel no fuera el único lugar para tocarse. Las vibraciones de los cantos, en su energía por el espacio, formaban hilos invisibles que movían los cuerpos.

Los participantes del taller que tuvimos la oportunidad de liderar un canto nos descubrimos ante la mirada de Thomas Richards, quien nos señalaba, con un gesto de sus manos, que era el momento de comenzar algunos de los cantos que habíamos aprendido. Richards guiaba con sumo cuidado los cantos de los participantes, mientras nos daba indicaciones como: "permite que eso vivo emerja de ti".

Al finalizar las sesiones, Richards acostumbraba repasar los cantos de cada uno y hacía comentarios. En mi caso, hizo la analogía con una cebolla. Dijo que me había movido por diversas capas, poco a poco. Me hizo recordar lo más importante: conectar mi corazón con mi hacer. Refirió que no se trataba de un asunto emocional, sino energético, "para que eso vivo se expresara".

\section{Los cantos vibratorios en las puestas en escena}

Para los participantes del taller fue importante presenciar las funciones de Gravedad y $\operatorname{Sin}$ Fronteras, dado que pudimos ser testigos de la acción de los cantos en el acontecimiento escénico. ${ }^{19}$ En las dos puestas en escena, los actores se comprometían profundamente con sus personajes, mediante caracterizaciones muy variadas y voces de cualidades diversas. Jaime Soriano señaló que este trabajo sobre la voz y la palabra en Grotowski es denominado singing-speaking (cantar-hablar), debido a que la sonoridad del texto tiene la capacidad de penetrar el cuerpo y lograr una sonoridad de la palabra

19 Thomas Richards investiga con los integrantes del Workcenter la manera en que pueden oscilar entre el trabajo realizado con los cantos rituales, bajo el enfoque del "arte como vehículo" para volver al "arte como presentación". La realización se hace pensando en la mirada del espectador, véase www.theworkcenter.org/about-the-workcenter/ 
encarnada (Entrevista). El legado de la herencia vocal de Grotowski pudo ser percibido en el trabajo de los actores en las puestas en escena.

Gravedad es un unipersonal con referencias autobiográficas, a cargo del actor Alonso Arbazúa Vallejos. Trata sobre el exilio de ciudadanos chilenos en Suiza, durante la década de los 70. Las caracterizaciones de sus personajes encarnan las distintas voces de ambos países -Suiza y Chile - con un alto espectro sonoro que lo compromete totalmente en su actuación. Fue posible observar cómo la voz de este actor vivía en cada personaje que encarnaba. Por el grado de sonoridad, Gravedad es un canto en sí mismo. Durante la función noté a varios espectadores conmovidos hasta las lágrimas. Posteriormente, Berenice Quirarte afirmó que "fue una de las obras de teatro más importantes" que había visto hasta el momento, mientras que yo quedé inspirado por el trabajo actoral (Entrevista).

La obra Sin fronteras fue una muestra colectiva del grupo del Workcenter Studio in Residence. Su tema giraba en torno a la recuperación de una ciudad tras la catástrofe del terremoto en Chile de 2010. Este trabajo, en comparación a Gravedad, poseía un mayor número de cantos, donde se podía apreciar que, de manera similar a las sesiones en los talleres, cada actor tenía momentos solistas y corales que llenaban la sala de vibraciones sonoras. Mariana Alarcón opinó que el trabajo de canto se basa en una "técnica antigua" que ahonda en las profundidades de las personas (Entrevista).

\section{Comentarios finales}

Para Jaime Soriano, este primer encuentro sumó muchos esfuerzos. Representó una muestra de lealtad con el maestro Jerzy Grotowski y su legado, de modo que ese hecho lo impulsó a gestionar las actividades en la Ciudad de México, después de la estancia que habían tenido previamente en Zacatecas: "era importante realizarlo como una especie de deuda hacia la gran generosidad del maestro Grotowski" (Entrevista), a la que también respondió Thomas Richards, quien aceptó no recibir pago de horarios. ${ }^{20}$

Soriano hizo una pequeña demostración en la que Thomas Richards y los miembros del Workcenter nos vieron realizar algunos elementos del training. Esta última sesión fue muy enriquecedora para mí, debido a que pude conocer el trabajo de entrenamiento actoral que Soriano realiza en su Laboratorio (LArtEs). Richards describió cómo su memoria se activó

20

Los costos de los talleres sólo financiaron los transportes y la producción de las obras. Incluso el hospedaje se realizó en la casa de una persona que ofreció su ayuda. Lo importante para Soriano era llevar a cabo la mayor cantidad de las actividades que promovieran la difusión del Workcenter en la Ciudad de México. 
al observar trabajar al maestro Soriano; nos narró las dinámicas que Soriano conducía en el momento en que ambos trabajaron con Grotowski, años atrás.

Thomas Richards ofreció comentarios constructivos a cada uno de nosotros; así, nos brindó imágenes y estímulos para seguir trabajando. También habló de la importancia de encontrar "the key", una llave o clave de entrada para el trabajo creativo. En suma, sus comentarios, las experiencias vividas durante el taller y el primer encuentro, despertaron nuevos impulsos creativos en los que participamos. En mi caso, impulsaron el deseo de seguir encontrando las llaves indicadas en los procesos creativos de la voz humana.

\section{Fuentes consultadas}

"Maud Robart - Spirit of singing". Association de Recherche des Traditions de l'Acteur. Association de Recherche des Traditions de l' Acteur, artacartoucherie.com/wiki/artists-and-contributors/maud-robart-spirit-of-singing/, consultado el 20 de febrero de 2019.

Workcenter of Jerzy Grotowski and Thomas Richards. The Workcenter of Jerzy Grotowski and Thomas Richards, www.theworkcenter.org/, consultado el 20 de febrero de 2019.

Alarcón, Mariana. Entrevista personal. 27 de julio de 2018.

Campo, Giuliano y Zygmunt Molik. Zygmunt Molik's Voice and Body Work. The Legacy of Jerzy Grotowski. New York: Routledge, 2010.

Fediuk, Elka. "El cuerpo de actor y perfomer en las investigaciones de Jerzy Grotowski". La actuación teatral. Estudios y Testimonios, compilado por Jorge Dubatti y Nidia Burgos. Bahía Blanca: Editorial de la Universidad Nacional del Sur, 2013, pp. 125-160.

Goiricelaya, María. El entrenamiento vocal del actor en los siglos XX y XXI. Hacia una antropología de la voz escénica en el marco de las técnicas teatrales contemporáneas. Tesis de doctorado en Investigación y Creación en Arte, Universidad del País Vasco, 2016.

Grotowski, Jerzy. Hacia un teatro pobre. Traducido por Margo Glantz. 24ª reimpresión. México: Siglo xxi, 2008.

Grotowski, Jerzy. “De la compañía teatral a El arte como vehículo”. Máscara, año 3, núms. 11-12, 1993, pp. 4-17.

Grotowski, Jerzy. “Técnica de la voz”. Máscara, año 2, núms. 4-5, 1991, pp. 182-201.

Monroy, Fidel. Voz para la escena. Ciudad de México: Escenología, A.C., y Centro de Estudios para el Uso para la Voz, 2011. 
Prieto Stambaugh, Antonio. "Drama objetivo y Arte como vehículo: testimonio de un waki en el umbral del espejo”. Jerzy Grotowski. Miradas desde Latinoamérica, coordinado por Domingo Adame, editado por Antonio Prieto. Xalapa: Universidad Veracruzana, 2011, pp. 143-166.

Quirarte, Berenice. Entrevista personal. 8 de agosto de 2018.

Richards, Thomas. "Treinta años del Workcenter: una retrospectiva”. Cátedra Ingmar Bergman, 19 de abril de 2018, Foro experimental "José Luis Ibañez" de la Facultad de Filosofía y Letras, Universidad Nacional Autónoma de México. Conferencia.

Richards, Thomas. Heart of Practice. Within the Workcenter of Jerzy Grotowski and Thomas Richards. Londres y Nueva York: Routledge, 2008.

Richards, Thomas. Trabajar con Grotowski sobre las acciones físicas. Madrid: Alba Editorial, 2005.

Richards, Thomas. Gravedad. Actuación y dramaturgia de Alonso Arbazúa Vallejos. Workcenter of Jerzy Grotowski and Thomas Richards y Fondazione Teatro della Toscana, temporada del 20 al 22 de abril de 2018, foro del Centro Cultural "Los Talleres", Coyoacán, Ciudad de México.

Richards, Thomas. Sin Fronteras, de Thomas Richards. Workcenter of Jerzy Grotowski and Thomas Richards y Fondazione Teatro della Toscana, temporada del 24 al 26 de abril de 2018, foro del Centro Cultural "Los Talleres", Coyoacán, Ciudad de México. Soriano, Jaime. Entrevista personal. 21 de julio de 2018. 


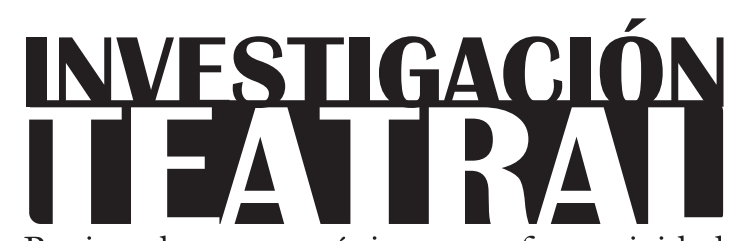

Revista de artes escénicas y performatividad

Vol. 10, Núm. 15

abril-septiembre 2019

Segunda época

ISSN impreso: 1665-8728

ISSN electrónico: 2594-0953

Universidad Veracruzana

\title{
Documento:
}

\section{La sombra de la feria}

\author{
Alain-René Lesage y \\ Jacques Philippe d'Orneval
}

Traducción e introducción: Alexis Álvarez Jácome*

\footnotetext{
* Departamento de Lenguas Extranjeras, Facultad de Idiomas, Universidad Veracruzana, México.

e-mail: alexis.aj88@hotmail.com
}

Recibido: 26 de junio de 2018

Aceptado: 10 de noviembre de 2018 


\section{Introducción al prólogo La sombra de la feria, de Lesage y d'Orneval}

A finales del siglo XVII, había en París tres instituciones oficiales que contaban con el privilegio del rey Luis XVI para representar teatro, música y danza en los escenaMúsica, aunque también había otros centros donde distintas compañías teatrales podían llevar a cabo las presentaciones de sus espectáculos.

Sin embargo, en algún momento aparecieron las ferias de Saint-German y Saint-Laurent, las cuales se turnaban para establecerse dos veces al año -en invierno y en verano, respectivamente-, durante dos o tres meses. Como resultado, surgió el género "teatro de feria", lleno de personajes de origen italiano, como Arlequín o Scaramouche, que comenzó a ganar cada vez más éxito, lo que provocaría celos, sobre todo, en quienes se dedicaban a la Comedia Francesa. Por lo mismo, paulatinamente, se establecieron coacciones, cada vez más radicales, que impedían el crecimiento del "teatro de feria". Como muestra, primero se prohibió la presentación de piezas enteras, luego se vetó el diálogo. Y, después del impedimento del uso del francés en el escenario, vino, por increíble que parezca, la prohibición de actores.

Como respuesta, los autores y los actores de feria hallaron ingeniosos y sorpresivos métodos para seguir conquistando el éxito y la aceptación del público parisino, como presentar, en un primer momento, escenas provenientes de distintas piezas, las cuales lograban concluir una historia planteada a través de ellas, regularmente en el penúltimo acto, o dirigir la palabra hacia un mudo, hacia una persona colocada entre bambalinas o hacia algún animal; incluso, se utilizó la pantomima para el desarrollo de la historia. El nuevo género atrajo a escritores franceses, como Alain-René Lesage, Jacques Philippe d'Orneval o Louis Fuzelier, quienes comenzaron a escribir piezas para estas compañías. 
Fue así como Lesage y d'Orneval alistaron este "prólogo", término que en ese momento no contaba aún con su connotación actual. Lejanamente a lo que podemos imaginar, consistía en una obra independiente que ofrecía al público las claves de la situación histórica, política y social en la que estaba envuelta. El "prólogo" no servía, entonces, como prefacio, sino como medio para obtener la captatio benevolentiae del público - una crítica exitosa-, así como para brindarle información verdaderamente útil para comprender los recursos utilizados en la gran pieza que le daría continuación al espectáculo. En este caso particular, La isla del Gugú (1720), escrita por Lesage y d'Orneval.

Es importante notar que la suerte de los autores de esta pieza no fue la misma para ambos. Por un lado, se encuentran muy pocos datos sobre la vida de d'Orneval, de quien lo único que se conoce es su colaboración con otros autores de teatro de feria, como Jacques Autreau (1657-1745), Louis Fuzelier (ca. 1672-1752) y Alexis Piron (1689-1773), cuyas obras se presentaron, principalmente, en las ferias Saint-Germain y Saint-Laurent.

Por el contrario, la vida de Lesage se muestra menos celosa con la historia y es recordado como un digno aprendiz de Molière; prueba de ello es su obra Turcaret o el Financiero (1709), que tuvo fuertes dificultades políticas en contra y se impidió su puesta en escena. Sin embargo, su Historia de Gil Blas de Santillana, publicada entre 1715 y 1735, es considerada no sólo su obra maestra, sino una novela canónica sobre las costumbres francesas y la última obra maestra del género picaresco.

Resulta sumamente interesante que, en sus años de juventud, el dramaturgo Alain-René Lesage hiciera traducciones de piezas de autores españoles al francés, como es el caso de Francisco Rojas Zorrilla y sus piezas La traición busca el castigo (Le traitre puni) y No hay amigo para amigo (Le point d'honneur); lo mismo que Lope de Vega y su obra Guardar y guardarse (Don Félix de Mendoce), sin olvidar Don César Ursin, nombre elegido para la traducción francesa de Peor está que estaba, de Pedro Calderón de la Barca.

No obstante, Lesage comenzó a cosechar sus primeros éxitos hasta 1707, cuando escribió obras propias, como Crispín, rival de su maestro, o su novela Le Diable boiteux, inspirada en El diablo cojuelo (1641) de Luis Vélez de Guevara (1579-1644). El año posterior escribió La Tontine, que fue representada hasta 1732, así que, con la sensación de encontrarse malgastando su talento y tras las múltiples trabas desatadas por la publicación de Turcaret, este dramaturgo buscó, al igual que Piron, llevar sus obras hacia el teatro de feria. De esta manera, en 1712 surgieron sus primeras piezas feriales: Los Pequeños Maestros y Arlequín y Mezzettino muertos por amor.

Lesage comenzó a relacionarse con los artistas más recurrentes en las ferias Saint-Germain y Saint-Laurent, entre los que se hallaba François Moylin (ca. 1695-1760), mejor conocido como Francisque, quien formó parte de una familia francesa de comediantes famosos del mismo siglo. Artista de grandes capacidades técnicas, podía realizar acrobacias 
en el escenario como parte de variados lazzi, escenas en su mayor parte improvisadas, sin texto, durante las cuales los actores podían hacer gala de sus capacidades físicas y técnicas. Su compañía de teatro formó parte de los grupos que disfrutaron de grandes éxitos en sus presentaciones durante 1718, lo que causó la ira de la Comedia Francesa, que al año siguiente vetó todo tipo de teatro, excepto las marionetas. Por ende, durante 1719, la compañía de Francisque se trasladó a Inglaterra para probar suerte. Regresó para la apertura de la feria Saint-Germain en febrero de 1720.

A pesar de contar con prolíficos datos sobre la vida de uno de los autores, La sombra de la feria fue rescatada del olvido por el Centro de Estudios de los Teatros de Feria y de la Comedia Italiana (Cethefi), fundado en 1999 por la doctora Françoise Rubellin, exdirectora del centro de enseñanza Pont supérieur, en Bretaña/País del Loira, y directora del Instituto de Estudios Avanzados (IEA) de Nantes, desde agosto de 2018. Madame Rubellin es profesora de literatura francesa del siglo XVIII en la Universidad de Nantes, especialista en Marivaux, teatro de feria, ópera cómica, marionetas, parodia y la edición de manuscritos de piezas de teatro del siglo XviII.

Finalmente, basta mencionar que la presente traducción es la primera propuesta en idioma español de La sombra de la feria de Lesage y d'Orneval de la que se tenga conocimiento hasta el momento, resultado del interés despertado en mí después de haber tomado el curso "Restricción e inventiva en las escenas del siglo XVIII", con Françoise Rubellin, en la Universidad de Nantes, durante la primavera de 2014.

Queda señalar que, tanto para la edición realizada por Jeanne-Marie Hostiou como para esta traducción, se emplearon dos diccionarios clave en la historia de la lengua francesa, debido a los cambios de significado que han sufrido algunos términos y expresiones con el tiempo. El primero es el Diccionario universal, de Antoine de Furetière, publicado en 1690. El segundo es el popularmente conocido como Diccionario de Trévoux, que fuera publicado a lo largo del siglo XVIII. Por este motivo se ha creído estéticamente conveniente la selección del dialecto peninsular, así como de algunas palabras en desuso de la lengua española. Asimismo, en esta traducción, a menos que se señale lo contrario, las notas a pie de página son autoría de Jeanne-Marie Hostiou, y únicamente se han traducido aquellas que el traductor ha creído necesarias para su comprensión en lengua española.

\section{Fuentes consultadas}

Centre d'Études des Théâtres de la Foire et de la Comédie-Italienne (Cethefi). Centre d'Études des Théâtres de la Foire et de la Comédie-Italienne, http://www.cethefi. org/, consultado el 28 de agosto de 2018. 
Centre National de Ressources Textuelles et Lexicales. Dictionnaire universel françois et latin [Dictionnaire de Trévoux]. París, 1740, www.cnrtl.fr/dictionnaires/anciens/ trevoux/menu1.php, consultado el 28 de agosto de 2018.

Furetière, Antoine. Dictionnaire universel contenant tous les mots françois tant vieux que modernes, et les termes de toutes les sciences et des arts [...]. París, 1690, www.gallica. bnf.fr/ark:/12148/bpt6k3413126b.r=dictionnaire\%20fureti\%C3\%A8re?rk=21459;2, consultado el 28 de agosto de 2018.

Lagarde, André y Laurent Michard. XviıIe siècle. París-Montreal: Bordas, 1970.

Le Théâtre de la foire à Paris. Universidad de Nantes, www.foires.univ-nantes.fr/, consultado el 28 de agosto de 2018.

Lesage, Alain-René. L'ombre de la foire. www.gallica.bnf.fr/ark:/12148/btv1b9061125f/f78. item.zoom, consultado el 28 de agosto de 2018.

Mancier, Frédéric. Le modèle aristocratique français et espagnol dans l'ouvre romanesque de Lesage - L'histoire de Gil Blas de Santillane: un cas exemplaire. París: Université de Paris-Sorbonne, 2001.

Real Academia Española. Diccionario de la lengua castellana, en que se explica el verdadero sentido de las voces, su naturaleza y calidad, con las phrases o modos de hablar, los proverbios o refranes, y otras cosas convenientes al uso de la lengua [...] [Diccionario de Autoridades]. Madrid, 1726 - 1739, web.frl.es/DA.html, consultado el 28 de agosto de 2018.

Rubellin, Françoise. Contrainte et inventivité sur les scènes du XVIII siècle [Notas tomadas por el traductor en este curso]. Université de Nantes, Nantes, 2014.

Thuret, Sylvie. Le théâtre espagnol de Lesage: la Comedia comme jardin cultivé en secret. París/Nanterre: Centre de Recherche en Littérature Comparée, Université de Paris-Sorbonne/Press universitaires de Paris Nanterre, 2012. 


\section{La sombra de la feria}

Traducción de Alexis Álvarez Jácome, basada en la edición de Jeanne-Marie Hostiou publicada en Théâtre de la Foire. Anthologie de pièces inédites 1712-1736, editado por Françoise Rubellin. Montpellier: Espaces 34, 2005, pp. 243-282.

\section{Prólogo en monólogo}

\section{Feria Saint-Germain, febrero de 1720}

\section{Personajes}

La sombra

Arlequín

Pierrot

Mezzettino

Scaramouche

El Doctor

Leandro

Argentina

Olivette

Pantaleón

Actor trágico

Un autor

Compañía de saltarines ${ }^{1}$

1 Acróbatas [Nota de Jeanne-Marie Hostiou. En adelante sus iniciales se indicarán de la siguiente manera: JMH]. 


\section{La sombra de la feria}

El teatro representa un lugar desierto con un lago.

\section{Escena I}

Arlequín, solo.

Entra con aire soñador y, gritando a sus camaradas, comienza así:

Lástima, mis queridos camaradas, ¿en qué se han convertido? ¿Y yo mismo, en qué me convertiré ahora? Me escriben a Inglaterra, ${ }^{2}$ en donde estaba yo como Juan por su casa, ${ }^{3}$ para venir a unírmeles a París, para presentarme en esta desdichada feria de Saint-Germain. Dejo enseguida este encantador país de guineas ${ }^{4}$ para unírmeles y, a mi llegada, no los hallo más. Me dicen que estas dos famosas magas ${ }^{5}$ (confabuladas desde hace mucho para nuestra perdición) se los llevaron, sin que sea posible saber dónde los han dejado, ni lo que de ustedes han hecho. ${ }^{6}$ ¿Qué haré yo sin dinero, entonces, y privado de aquellos que me ayudan a ganarlo? Será que deba ir de puerta en puerta preguntando: "Señora, ¿su perro no muerde?” Oh, fortuna!... Pero me percato de que mi ensoñación me condujo de manera imperceptible a un lugar solitario, donde no encuentro el socorro del cual necesito. Intentemos encontrar el camino correcto, informémonos si no existe por los alrededores algún castillo donde pueda pagar mi escote ${ }^{7}$ con alguna pieza de comedia, el único bien que me queda.

2 Francisque presentó Arlequin esprit follet en Inglaterra, junto con su compañía, el 8 de enero y el 12 de febrero de 1719, en el King's Théâtre [jмн].

3 En el original francés Rat en paille, que traducido literalmente significa "rata en paja" [Nota de Alexis Álvarez Jácome. En adelante sus iniciales se indicarán de la siguiente manera: AAJ].

4 Guinea: otrora moneda de oro utilizada en Inglaterra [JмH].

5 Mago: "Aquel que realiza cosas extraordinarias a través de poderes diabólicos" (Trévoux). Un asterisco [escrito en el manuscrito original, que puede ser consultado en el sitio de internet de la Biblioteca Nacional de Francia, https://gallica.bnf.fr/ark:/12148/btv1b9061125f/f78.item.zoom, AAJ] reenvía a una nota al margen que precisa: "Las dos Comedias" [JMH].

6 Un edicto real, motivado por la presión de las Comedias francesa e italiana, había llevado a la prohibición de representaciones teatrales en las ferias de 1719 [JMH].

7 Escote: Lo que cada uno paga por su parte de una comida grupal que se realiza [en la tercera entrada del término "escote" del Diccionario de autoridades, tomo III (1732), disponible en http://web.frl.es/DA.html, 
En el momento, se alza un vapor a dos pasos de Arlequín; un largo gemido le agobia los oídos, gira su vista hacia el costado del lago y divisa una sombra que brota del seno de la tierra.

¡Hoimé! ${ }^{8}$ ¿Qué veo?...

Quisiera esfumarse, pero es presa de un espasmo que le roba las fuerzas.

\section{Escena II}

Arlequín, La sombra.

Pts... pts... pts...

La sombra, llamando a Arlequín.

Arlequín, aparte.

¡Ay, ay! Ésta me llama. Si me acerco, estoy muerto; si retrocedo, estoy frito.

La sombra, continuando.

Pts... pts... pts...

¿Pero no me hará daño?

\section{Arlequín}

La sombra le hace señas de que no.

Dígame de lejos lo que quiere.

\section{Arlequín}

Le muestra un papel que sostiene y le hace señas para que se acerque a mirarlo.

se lee: "Vale tambien [sic] la cantidad y parte que prorata cabe a cada uno de los que se han divertido o comido en compañía, por razón del coste y gasto hecho [...]", AAJ].

8 Hoimé: "Ay", exclamación que recuerda los orígenes italianos de Arlequín [JMH]. 
Da algunos pasos temblando.

Arlequín

Me causa un gran pavor. ¡Váyase!

La sombra

Le hace señas una vez más para que se acerque.

\section{Arlequín}

Vayamos, entonces. Avanza unos pasos hacia La sombra, y alarga el brazo tanto como puede, para coger el papel. Por fin lo coge, y regresa prontamente sobre sus pasos para leerlo lejos de La sombra. Durante este tiempo se abstrae. Lee las siguientes palabras.

\section{Escena III}

\section{Arlequín, solo, leyendo.}

"Mira a La sombra de la feria, querido Arlequín..."

Ja, ja, es un fantasma que me conoce (gira la cabeza para ver a La sombra, a la cual ya no encuentra). Pero se ha ido; hizo bien. Veamos qué quiere decir...

"Mira a La sombra de la feria, querido Arlequín..."

¡La sombra de la feria! ¡Madre santísima! Lástima, ¿por qué desaparece tan pronto? Le habría entretenido sin temor, querida sombra... Veamos el resto.

"Mira a La sombra de la feria, querido Arlequín Quien posee un corazón sensible a tus dolores.

A tus pies bajo esta negra piedra hallarás por fin Algo con qué poder curar tus sinsabores."

¿Qué alegría! Corramos a quitar la piedra que, sin duda, debajo hay algún tesoro escondido (va a arrodillarse frente a una gran piedra negruzca que está en medio del teatro. La besa y, alzándola un poco, mete la mano en un hoyo que está debajo; la retira muy rápidamente). ¿Pues qué demonios hay ahí? ¡Me rasguñó! Bien dicen que no hay rosa sin 
espinas (quita por completo la piedra del hoyo, del cual salen dos grandes gatos huyendo. Arlequín retrocede aterrado). ¡Oh, cielos! ¿Qué es eso? Pronóstico errado, siempre hay malicia en los fantasmas mejor intencionados. Sin embargo, atrevámonos a ser mordidos tanto por un gato como por un perro (regresa al hoyo, mueve la mano dentro, temblando, $y$ tira de una cuerda. Dice tristemente). ¡El gran tesoro! (Repite las últimas palabras de La sombra).

"Algo con qué poder curar tus sinsabores."

Sí, tiene razón; cuando yo me haya estrangulado ya no sufriré más. Al parecer la Feria creyó que si no me ahorcaba era debido a no tener con qué comprar una cuerda, y quiso proveerme de una. Efectivamente, es lo más honesto que puedo hacer dada la situación actual. La sombra me ha mostrado mi quehacer, vamos, estrangulémonos valientemente. (De manera cómica, se pasa la cuerda entre las piernas, bajo las axilas y después por el cuello, hace muchas piruetas sosteniendo con una mano la cuerda en el aire y, sin poder estrangularse, habla) ¡Caramba, no hago nada que valga la pena! He aquí lo que es hacer un trabajo que no se conoce. Pero allá diviso un árbol que me ofrece sus ramas para anudar mi cuerda. Me parece que allí me colgaré con más decencia y más a mi gusto (va para anudar su cuerda al árbol, pero la punta de la cuerda, que aún está en el hoyo, lleva una vara). Ja, ja, ¿qué significa esto? (Jala la vara, que tiene amarrada al final otra cuerda aún más grande, y al final de esta cuerda hay una red de pescar). Menudos cachivaches; sin duda, son los cacharros de algún pescador de la región con los cuales pesca en el lago... Esto me lleva a una reflexión: ¿no habrá querido La sombra darme un medio para tramar algo? Tal vez su deseo es que por esta ocasión use esto para pescar en este lago, y coja peces que enseguida iré a vender, y por los cuales obtendré dinero. ¿Por qué no? Rayos, intentemos eso. He aquí un sedal, creo. Sí, así es. Veo en el borde un anzuelo y un gobio ${ }^{9}$ que tiene como carnada. Voy a probar suerte; siempre estaré a tiempo de ahorcarme, si no lo logro (lanza el sedal en el lago y hace todos los gestos de un pescador). Efectivamente, el pez muerde ya el anzuelo (tira del sedal y saca a Mezzettino).

9 Gobio: pequeño pez de agua dulce [JMH]. 


\title{
Escena IV
}

Arlequín, Mezzettino.

\begin{abstract}
Arlequín
Diablos, he aquí una buena y gran caballa. ${ }^{10}$ (Levanta a Mezzettino que está acostado pecho tierra y, reconociéndole, habla). Pero ¿qué veo? Este pez se asemeja a Mezzettino como dos gotas de agua.
\end{abstract}

Mezzettino sonríe a Arlequín.

Arlequín

Es Mezzettino en persona... Deja abrazarte, mi querido amigo... Eh, ¿por qué aventura te hallas en este lago?

Mezzettino junta los puños y levanta las manos al cielo.

Háblame, entonces.

\section{Arlequín}

Mezzettino deja ver que está mudo al llevarse el dedo a la boca.

¡Te has vuelto mudo!

\section{Arlequín}

Mezzettino le indica con sus gestos que es un pez.

\section{Arlequín}

¡Ay, sorte becca! ${ }^{11}$ ¡Mi querido Mezzettino se ha convertido en pez! No podrá responderme dado que los peces no hablan.

Mezzettino le muestra el lago y le indica con los dedos que toda la compañía está ahí metamorfoseada en pez.

10 Pez algo verdinegro de una tercia de largo y una mano de ancho. No tiene buen sabor, aunque se come fresco y salado [Diccionario de autoridades, tomo III (1729), http://web.frl.es/DA.html, AAJ].

11 Literalmente: "especie de cornudo" [јмн]. 


\section{Arlequín}

¡Todos tus camaradas y los míos están en este lago convertidos, como tú, en animales acuáticos! ¡He aquí entonces el resultado de la malicia de nuestras enemigas las magas, y he aquí los actores que La sombra de la feria me hace encontrar! Tengo mucha ventaja, han perdido el uso de la palabra. ¿En qué salsa pondré estos peces?

\section{Mezzetino hace el salto de carpa. ${ }^{12}$}

Arlequín

Saltarás, mi buen perro boticario. ${ }^{13}$ Vayamos, continuemos la pesca si de algo sirve (comienza a pescar nuevamente y saca al Doctor).

\section{Escena $\mathbf{v}$}

\section{Arlequín, Mezzettino, El Doctor.}

\section{Arlequín}

He aquí una marsopa. ${ }^{14}$ Bondi signor Doctor,${ }^{15}$ tampoco hablas tú. ¡Doctor pezonificado!

\section{El Doctor}

Sacude la cabeza y hace seña de que no.

\section{Arlequín}

Haremos de este grupo una compañía de mudos. Colocaros cerca de vuestro camarada, mi amigo (retoma la pesca y saca a Leandro).

12 Salto en el que uno se para sobre los pies, de un golpe, estando acostado boca arriba [JMH]

13 Arlequín anuncia el primer principio de las piezas en monólogo: la importancia de los saltos, del juego de los acróbatas, y así de lo esencial de lo visual y lo espectacular. Los saltos serán el remedio ("boticario") contra todas las censuras infligidas por la Comédie-Française [JMH].

14 Marsopa: "Pez grande de mar bastante gordo [...] Colocado en la categoría de pescado graso, mientras que el delfín es colocado en la categoría de los peces reales. [...] Se le llama irónicamente también a un hombre gordo y lleno de grasa, una marsopa" (Trévoux). El personaje de El Doctor es [tradicionalmente] gordo y grasoso [JMH].

15 Buenos días, señor Doctor, en italiano [JMH]. 


\section{Escena VI}

Arlequín, Mezzettino, El Doctor, Leandro.

\section{Arlequín}

Pestes, he aquí un delfín de escamas doradas, nuestro Leandro. En cuanto a usted, señor enamorado, ${ }^{16}$ hará bien el amor mediante gestos. ${ }^{17}$ Basta rotar los ojos, suspirar, tomar la mano, etcétera, para representar su papel. ${ }^{18}$ Colóquese allí con sus demás camaradas, yo continuaré mi tarea (retoma la pesca y saca a Scaramouche).

\section{Escena VII}

Los precedentes, Scaramouche.

\section{Arlequín}

Pesqué un barbado. ${ }^{19}$ Póngase cerca de los otros, señor Scaramouche. ¡Por el resto! (nuevamente lanza el sedal y trae a Pantaleón y a un actor trágico).

\section{Escena VIII}

Los precedentes, Pantaleón, un actor trágico.

\section{Arlequín}

¡Oh, cielos, ahora dos de un golpe! Estos son, ciertamente, dos lucios ${ }^{20}$ de buen tamaño, miden más de dos pies entre cola y cabeza.

16 Leandro, al igual que Octavio, Valerio o Clitandro, encarna los papeles de enamorado [JмH].

17 Hacer el amor: "Cortejar, buscar complacer a una mujer buscando hacerse amar" (Furetière) [JMH].

18 Arlequín anuncia un segundo principio de las piezas en monólogo: los actores mudos recurrirán a la mímica $[\mathrm{JMH}]$.

19 Tiberio Fiorilli, el ilustre Scaramouche del Ancien Théâtre-Italien, llevaba una barba de chivo (Barbue en el original, que en español es un pez plano conocido como rémol o rodaballo) [AAJ].

20 Con la aparición de las Comedias francesa e italiana bajo la forma de dos lucios, la metáfora insinuada cuenta con una fuerte crítica incisiva: el lucio es un "pez de agua dulce, largo y muy glotón que se come a los demás. Los dientes del lucio son muy venenosos" (Furetière) [JMH]. 


\section{El actor trágico, declamando. \\ "Tarán tantán tarán tantán terán tantán". \\ Arlequín, imitándolo. \\ “Tarán tantán tarán...”}

Es un pez muy exquisito para nosotros, señor Tarantantán, no necesitamos más que los desechos. Con nosotros no serviría ni para rostizarle ni hervirle; así que, tómese la molestia de irse a... ser recibido en otra parte.

\section{Escena IX}

Los precedentes, Pantaleón

Pantaleón, saludando.

Assabara, gae gae gae.

\section{Arlequín}

¡Es un pez italiano! $!^{22}$ Bene bene. Podemos quedárnoslo, no causará envidia hacia la compañía. Colóquese en fila con los demás, Signor Pantaleón. Pero no atraigo más que machos, mucho quisiera también pescar algunos peces hembra (Mezzettino le muestra el esparavel y le indica que encontrará una si lo lanza en el estanque). ¡Ah! No pican el sedal, usemos pues nuestra red.

Lanza el esparavel y atrapa a Argentina con Olivette.

21 Parodia de la declamación de un verso alejandrino [JMH].

22 Pantaleón encarna, frecuentemente, la Comedia italiana: al contrario de numerosos personajes de la Commedia dell'Arte como Arlequín o Scaramouche, el personaje de Pantaleón no fue adoptado por la Foire y permanece como un símbolo de los italianos [JMH]. 


\section{Escena $\mathbf{x}$}

Los precedentes, Argentina, Olivette.

\section{Arlequín}

¡Caramba, la gran redada! ¡Amable pesca, lindas truchas que saben cómo vivir! Se ve que no se criaron en el fango con las tencas, pero hay una a la que he visto en alguna parte.

\section{Olivette, cantando.}

Melodía: No nací ni rey ni príncipe. ${ }^{23}$

Yo soy la que representó a Olivette.... ${ }^{24}$

\section{Arlequín le pone la mano en la boca.}

Despacio, señorita Olivette, despacio; así como va, caray, nos sería un buen negocio con sus estrofas de la Opéra-Comique. Este pez hembra no es mudo y, por lo que veo, el género femenino cotillea por doquier. Sí, la anguila de Melun ${ }^{25}$ hablaba también, ya que se dice que gritaba antes de que se le desollase. Escuche, mi damisela, si desea quedarse con nosotros tendrá que cuidar su lengua. (A Argentina) Usted, usted tampoco hablará.

No.

\section{Argentina}

\section{Arlequín}

Chist... estas mujeres... No hablen más, doncellas mías, serán dos rarezas que todo París vendrá a ver. ¡Ja! Caray, antes de encaminarnos a esta gran ciudad me gustaría mucho que fuéremos provistos de un buen autor, ¿no habrá uno en este lago?

23 Aire francés cuyo nombre original es Je ne suis né ni roi ni prince [A AJ].

24 Nótese el efecto, que consiste en romper la ilusión cómica: Arlequín reconoce a la actriz real que encarna el personaje de Olivette (de ahí la respuesta de esta última: "La que representó [...]" y no: "la que representa a Olivette") [JMH].

25 Anguila de Melun: "Es una anguila de Melun, grita antes de desollarla, para decir: tiene miedo sin razón. Este dicho viene a raíz de que alguien llamado La Anguila, burgués de Melun, quien en una comedia representaba el personaje de San Bartolomé, viendo al verdugo, cuchillo en mano, que hacía señas de desollarlo, se puso a gritar fuertemente antes de que le tocase: fue tan divertido, que dio pie al dicho" (Furetière). Arlequín invierte la relación de causa y efecto, puesto que la anguila gritaba por miedo a ser asesinada y La Feria está en riesgo de ser destruida por haber hablado: efecto cómico que siempre alimenta la metáfora acuática insinuada [JMH]. 


\section{Mezzettino le hace entender mediante gestos que hay uno excelentísimo.}

\section{Arlequín}

¿Hay uno excelente, asegura? Je, rápido, ¡el sedal!

\section{Mezzettino detiene a Arlequín y retirando el gobio de su se- dal coloca en su lugar una moneda de oro.}

\section{Arlequín}

¿Qué quieres hacer?... Ah, comprendo, muy bien pensado; una moneda de oro. Sí, un autor no escapará a esta carnada (lanza el sedal y coge a Pierrot por una de sus mangas, ${ }^{26}$ que se extiende más de tres anas $\left.{ }^{27}\right)$.

\section{Escena XI}

Los precedentes, Pierrot, quien se acerca con una mirada estúpidamente fija.

\section{Arlequín}

¡Qué diablos! ¡Es un pescado molinero ${ }^{28}$ lo que he atrapado! ¡Pero no, es nuestro amigo Pierrot! Así que, eh, ¿te has convertido en un alma virtuosa? ${ }^{29}$

\section{Pierrot le hace una seña de que sí.}

\section{Arlequín}

¿Pero no eres también un autor de agua dulce? ${ }^{30}$

26 Sin duda alguna, los actores de la feria no estaban caracterizados como peces: aparentemente, Pierrot viste su habitual traje holgado [JMH].

27 Alna, ana: unidad de medida de tejidos que "a menudo se emplea popularmente y en la conversación para indicar una grandeza desmedida comparada con la cosa de la cual se habla" (Trévoux) [JMH].

28 Molinero: pescado con la "piel blanca y blanda, lo que la vuelve más valiosa" (Furetière). La selección del pescado no es anodina, siendo el mismo Pierrot tradicionalmente un molinero, con un traje blanqueado por la harina $[\mathrm{JMH}]$.

29 La aparición de Pierrot como autor crea un efecto cómico, siendo este personaje conocido comúnmente por su ausencia de virtud [JMH].

30 Se dice "un médico de agua dulce, es decir un médico incompetente cuyo único remedio consiste en agua 
Pierrot toma suficiente aire y extrae de sus bolsillos muchos libros, en su mayor parte cubiertos de papel azul. ${ }^{31}$

Arlequín

Entonces, he aquí tu biblioteca, crío mío. Veamos. (Lee los títulos de los libros) Pierre de Provence, Richard sans peur, L'Espiègle, Le Mercure galant. ${ }^{32}$ Pestes, son cuatro buenos libros los que tienes aquí. Ja, caray, aquí hay unos actores peces; tú eres un autor acuático, haznos una piececita de intriga... Así, como quien diría, de un viejo cangrejo enamorado de una joven perca, de una ballena que se interesa en un boquerón.

Pierrot le hace seña de tener una pieza como ésa en su bolsillo.

\section{Arlequín}

Pero hace falta que sea digna de actores, o sea, mudos, y que no haya nadie más que yo, que no he sido transformado en pez, que pueda hablar; pues si éstos osaren responderme, tendríamos en París por vecinos a terribles cocineros, que nos pondrían prontamente en un caldo para pescado.

Pierrot, dándole un papel.

Bary bary barae.

\section{Arlequín}

Por supuesto. No habrá problema cuando nuestros peces balbuceen un poquito; a eso no se le dice hablar. He aquí la pieza por donde iniciaremos. (Lee) "La Isla del Gugú, pieza en

dulce" (Furetière) [JMH].

31 Los libros azules, o Bibliothèque bleue, centrados en la cultura popular, circulaban en el campo por medio de los vendedores ambulantes. Eran pequeños libros muy baratos, cubiertos de papel azul y sin pretensiones literarias, que explotaban con éxito un capital literario heredado de la Edad Media [JMH].

32 Pierre de Provence et la belle Maguelonne [Pedro de Provenza y la bella Maguelona], novela de caballería del siglo xv, y la Histoire de Richard sans peur, duc de Normandie, fils de Robert le Diable [Historia de Ricardo sin miedo, duque de Normandía, hijo de Roberto, el Diablo], reimpreso en 1705 en La Bibliothèque bleue, eran grandes éxitos literarios populares. L’Espiègle [El Pícaro] es el título de "una pequeña novela donde se describen andanzas maliciosas y canalladas" (Trévoux) y "Le Mercure Galant [El Mercurio Galante] del señor Visé es un compendio que ofrece mensualmente diversas noticias, y obras galantes, que en las provincias mantiene un comercio de estudio y de galantería" (Trévoux) [JMH]. 
INVESTIGACIÓNTEATRAL

Revista de artes escénicas y performatividad

Vol. 10, Núm. 15

abril-septiembre 2019
La sombra de la feria

Alain-René Lesage y Jacques Philippe d'Orneval

monólogo con grandes lazzi, alborotos, nigromancias, máquinas et catera". Es todo lo que necesitamos. Señores, haremos todo lo que podamos para hacerles picar el anzuelo. ${ }^{33}$

Los saltarines hacen su presentación.

33 El desenlace de la metáfora "pez", insinuada en todo el prólogo, recae aquí en un giro cómico: a partir de ahora es el público quien, a semejanza de los actores, se ve transformado en pez, puesto que deberá morder el anzuelo de los actores de la feria [JMH]. 


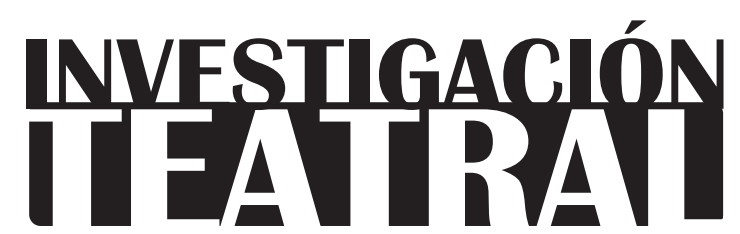

Revista de artes escénicas y performatividad

Vol. 10, Núm. 15

abril-septiembre 2019

Segunda época

ISSN impreso: 1665-8728

ISSN electrónico: 2594-0953

Universidad Veracruzana

Reseña de

puesta en escena:

\title{
Lo que queda de nosotros, de Alejandro Ricaño y Sara Pinet
}

\author{
Wendoline Robles Hernández*
}

\footnotetext{
* Maestría en Artes Escénicas,

Universidad Veracruzana, México.

e-mail: robleswendoline@gmail.com
}

Recibido: : 20 de noviembre de 2018

Aceptado: 20 de febrero de 2019 


\section{Lo que queda de nosotros, de Alejandro Ricaño y Sara Pinet}

$\mathrm{E}$ 16 de noviembre de 2018, en Xalapa, Veracruz, los dramaturgos Sara Pinet y Alejandro Ricaño presentaron dos únicas funciones de Lo que queda de nosotros, dentro del ciclo de invitados del foro teatral Área 51, ubicado en la zona centro de la ciudad. Con una duración de 60 minutos, este espectáculo, estrenado en 2014 y dirigido por Ricaño, cuenta con un elenco conformado por el actor Raúl Villegas y la misma Pinet, la asistencia de dirección Álvaro Zúñiga, así como sonorización en vivo a cargo de los músicos David Ortiz y Ricardo Estrada. Ambas funciones, llevadas a cabo a las 18:00 y 20:00 horas, llenaron el recinto teatral, con un aforo de aproximadamente 90 espectadores cada una.

Alejandro Ricaño es considerado uno de los creadores más sobresalientes del teatro mexicano del siglo xxi; ha escrito y dirigido obras con gran éxito taquillero y buena recepción por parte de la crítica. Entre sus títulos más destacados se encuentran Riñón de cerdo para el desconsuelo (2008), Más pequeños que el Guggenheim (2008), Idiotas contemplando la nieve (2010), Fractales (2011) y El amor de las luciérnagas (2012). Además, escribió y dirigió la trilogía de monólogos Cada vez nos despedimos mejor (2013), con la actuación de Diego Luna; Un hombre ajeno (2014), con el actor José María Yazpik, y Hotel Good Luck (2015), con el actor Luis Gerardo Méndez. Actualmente, incursiona en el ámbito de la dirección en una serie televisiva.

Lo que queda de nosotros es una puesta creada para un público infantil y juvenil, a partir de los diez años de edad, y fue ganadora del Premio de Teatro para Niños INBA 2014. Un teatro evocativo, cuya estética híbrida -el tono fársico y el emplazamiento realista- posee todas las convenciones del teatro narrado. La trama se desarrolla en un entretejido de tex- 
INVESTIGACIÓNTEATRAL

Revista de artes escénicas y performatividad

Vol. 10, Núm. 15

abril-septiembre 2019
Lo que queda de nosotros, de

Alejandro Ricaño y Sara Pinet

Wendoline Robles Hernández

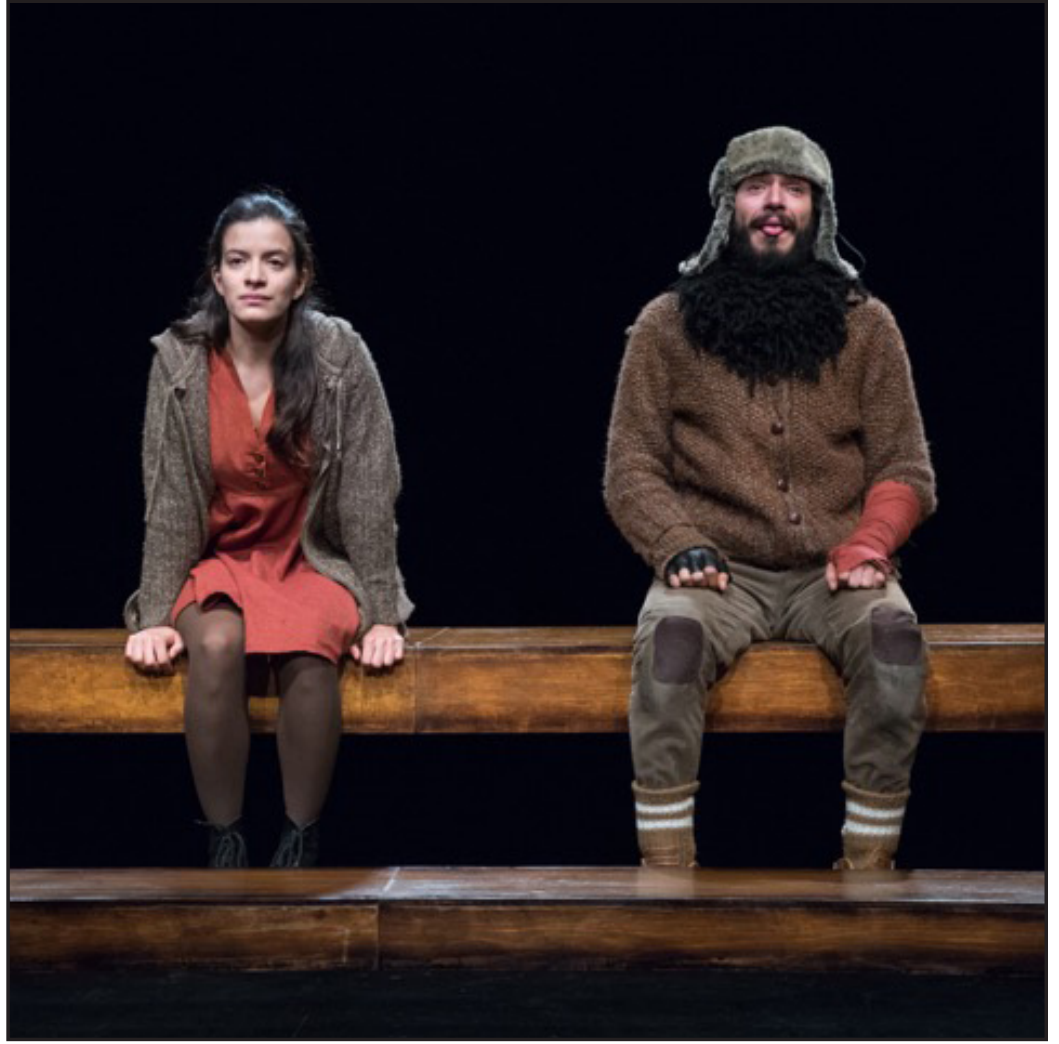

Sara Pinet y Raúl Villegas. Sala Xavier Villaurrutia del Centro Cultural del Bosque. Ciudad de México, 2015. Cortesía de Raúl Villegas. Fotografía de César Martínez.

to, acción y música, con trazos espaciales mínimos y diálogos casi inexistentes, dentro de un espacio neutro, desde el que los actores pueden resignificar cada uno de los personajes, así como cada uno de los sitios que van surgiendo a lo largo de la ficción.

Escrita en tono cómico-dramático, Lo que queda de nosotros narra la historia de Toto (Villegas) y Nata (Pinet): una aventura hacia el reencuentro entre un perro y su dueña. Es un recorrido que nos invita a reconocernos en el sentimiento de soledad de una chica que ha quedado huérfana, a quien las crisis recurrentes llevan a reflexionar sobre el amor, la amistad, la responsabilidad y el dolor. Al mismo tiempo, este viaje muestra la historia de un perro que, tras ser abandonado por su joven dueña, resiste las adversidades de la vida callejera, siempre motivado por el profundo amor que siente hacia ella. Esta obra revela, a través de dolorosas experiencias, cómo Nata comprende el sentido de la pérdida propia y ajena y vive su duelo dispuesta a remediar el abandono de Toto, determinada por la esperanza de sanar juntos.

En una actuación que asimila armónicamente la gestualidad canina, Villegas hace un tránsito hacia la naturaleza sensorial y emocional de los perros, llevando su corporalidad 
INVESTIGACIÓNTEATRAL

Revista de artes escénicas y performatividad

Vol. 10, Núm. 15

abril-septiembre 2019
Lo que queda de nosotros, de

Alejandro Ricaño y Sara Pinet

Wendoline Robles Hernández

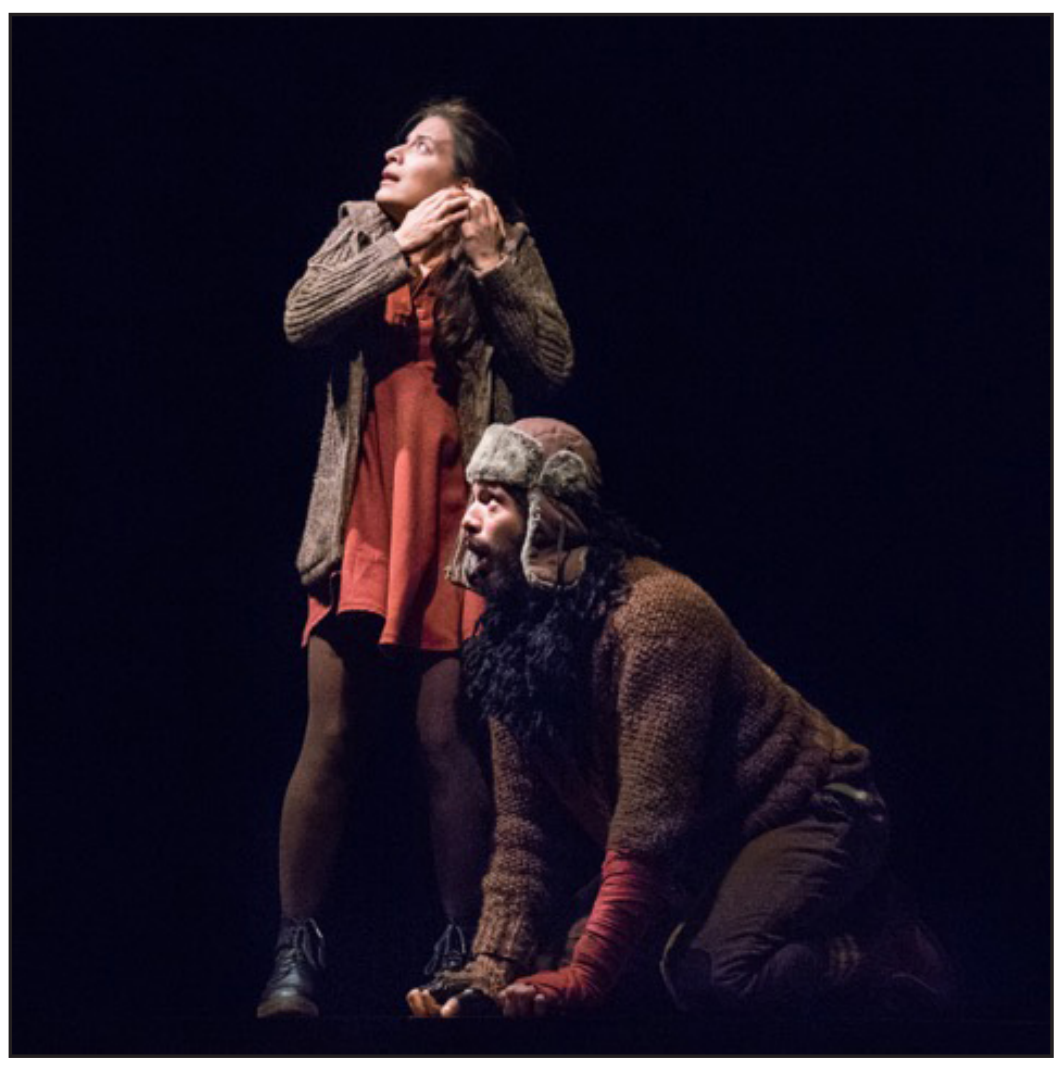

Sara Pinet y Raúl Villegas. Sala Xavier Villaurrutia del Centro Cultural del Bosque. 2015. Cortesía de Raúl Villegas. Fotografía de César Martínez.

a un sagaz habitar de la esencia cuadrúpeda de aquellos que, durante siglos, han sido considerados fieles amigos del hombre. Sobre la construcción del personaje, en entrevista con el canal de protección canina Perrisección 2, el actor explica que fue de mucha ayuda usar su imaginación:

Creo que fue a partir de preguntarme qué le sucedería, cómo sería el pensamiento de mi perra si no estuviera conmigo, o si alguien le quitara su casa... cómo reaccionaría, qué le dolería. Evidentemente, todo tiene un raciocinio humano, pero me gustó meterme a creer cómo es la mente de mi perra o de otros perros que conozco. Mi imagen de cómo se mueve Toto está basada en los perros de Ricaño y Sara, pero la imagen de cómo piensa es de mi perra. Todo está basado en mi filtro... creo que traté de ponerle palabras a mi perra ("Entrevista-invitación").

Hay momentos brillantes de Toto que están concebidos para empatizar con el personaje, como si alguna vez hubiésemos sabido lo que significa ser perro. Uno de estos aciertos 
es la interpretación de Raúl Villegas, cuando Toto es informado por Crispín - un can vagabundo, encarnado por el mismo actor- sobre la adversidad de la vida callejera. Crispín, masticando un hueso imaginario, es apoyado por una luz blanca que evoca los callejones solitarios, además de una sonorización que infunde suspenso y, al mismo tiempo, provoca comicidad, mientras nos conduce a través de un relato que dibuja una realidad de la que queremos librar a Toto.

Por otro lado, a pesar de que la habilidad actoral de Pinet es indiscutible y su personaje, Nata, posee un argumento digerible y entretenido que nos permite seguir buena parte de sus cuestionamientos, temores y fracasos, la narración excede la complejidad de la personalidad de Nata a nivel escénico, lo cual probablemente sea consecuencia del enfoque afable de la puesta. Sus pérdidas, sus crisis, su preferencia por la soledad y sus matices de esperanza se dan a conocer a partir de aspectos que conforman cierto estereotipo de la adolescencia enfadada y rebelde, cuya representación se sostiene por un estado de antipatía permanente y algunos destellos de humor.

Un acierto en la puesta es la sencillez y la operatividad del dispositivo escenográfico, a cargo de Ricardo Ricaño: una enorme mesa rectangular de madera maciza, que ocupa el centro del escenario, y una banca del mismo material, empotrada sobre dos rieles que se prolongan paralelos en el piso, por debajo de la mesa. El mecanismo de ésta, evidentemente estudiada por el elenco, le permite realizar cambios de tiempo y lugar dentro de la narración, otorgando dinamismo y fluidez a la obra. A su vez, esta disposición proporciona un espacio homogéneo para la construcción de cada acontecimiento, al permitir aislar o integrar las acciones de los personajes, según se requiera. Otro de los temas que es preciso reconocer, tanto de la dirección, como de la interpretación, es el rasgo coreográfico determinado para ciertos momentos de la partitura escénica; la precisión con que son ejecutados los movimientos, así como el ágil manejo rítmico y corporal, otorga un carácter fresco y lúdico a la puesta, que estimula nuestra empatía kinestésica.

La ambientación de escena no posee complejidad alguna y, a excepción de los cambios en la iluminación y la música, se mantiene inalterable. Tanto los músicos, como los actores, están en escena, incluso antes de que el público ingrese a la sala. No hay telones, ciclorama o utilería de mano, y la única referencia que tenemos para imaginar el lugar o la atmósfera en que se lleva a cabo la historia nos la proporciona un solo aspecto del vestuario, diseñado por Alejandra García: gorros con orejeras para el frío.

Al inicio de la obra podemos ver a Sara Pinet con la espalda erguida, las manos juntas en su regazo y la cabeza cubierta por el gorrito color café de su suéter tejido, sosteniendo la mirada fija en un horizonte frente a ella. Se encuentra sentada en el centro del tablero de la mesa y lleva un vestido naranja casi a la altura de las rodillas, además de unas medias 
color café oscuro que sobresalen de unas botas negras con agujetas. En el extremo derecho, sentado sobre la banca, Raúl Villegas, revela un estado más próximo, inmediato, con un semblante casi sonriente, habitando una dimensión distinta a la de Pinet. Sus facciones se configuran desde un estado cercano a la ensoñación; un tono juguetón, con un matiz de ingenuidad, brilla en sus ojos expresivos, enmarcados por su gorro invernal. En el fondo, los músicos David Ortiz y Ricardo Estrada permanecen de pie, uno a cada costado del escenario con sus instrumentos de cuerda: un violonchelo eléctrico y una guitarra, cuyos acordes, algunas veces harán la ambientación, y otras, completarán el cuadro dramático. Aunque Ortiz y Estrada no intervienen en la ficción que se desarrolla, su presencia atiende todo el tiempo a la idea estética de la misma, mientras su vestimenta y gorros con orejeras complementan la plástica de la puesta.

El diseño de iluminación, realizado por Matías Gorlero, es sobrio. En algunas escenas, la luz frontal apoya el universo común de los personajes y, en otras, el juego de luces cenitales señala un cambio de espacio y ambiente dentro de la trama. Así, hay momentos en los que el foro se ilumina sutilmente por la cálida luz amarilla que irradian unas bombillas eléctricas que cuelgan desiguales a la altura de los músicos. Los únicos elementos que conforman el decorado escenográfico son algunos platos de alimento para perros, fabricados en plástico translúcido color rojo con decorados de huesitos negros, que penden entre los focos con distintas inclinaciones.

Lo que queda de nosotros es un espectáculo escénico que abarca todos los componentes propios de la estética de Alejandro Ricaño. En él se despliega, con maestría, su más conocido recurso: la narraturgia -o su particular estilo de narrar e ilustrar en la acción el acontecimiento escénico de manera fresca y simultánea-, prescindiendo de la oralidad y los diálogos. La capacidad de la puesta para aproximar emotivamente las vivencias de los personajes a la audiencia, mediante un manejo diestro del dolor y la ironía, logra cumplir con el objetivo de los dramaturgos de sensibilizar al espectador sobre la amistad y el respeto a la vida en todas sus formas. Lo que queda de nosotros es un trabajo creativo, sólido, nutrido de los ingredientes necesarios para brindar una experiencia memorable.

\section{Fuentes consultadas}

Pinet Sara y Ricaño, Alejandro. "Entrevista-invitación a obra de teatro LO QUE QUEDA DE Nosotros". YouTube, subido por Perrisección 2, 13 de julio de 2018, www.youtube. com/watch?v=cdTTeHaMOWo, consultado el 20 de febrero de 2019. 
INVESTIGACIÓNTEATRAL

Revista de artes escénicas y performatividad

Vol. 10, Núm. 15

abril-septiembre 2019
Lo que queda de nosotros, de

Alejandro Ricaño y Sara Pinet

Wendoline Robles Hernández

Ficha técnica de Lo que queda de nosotros

Director: Alejandro Ricaño

Dramaturgia: Alejandro Ricaño y Sara Pinet

Asistente de dirección: Álvaro Zúñiga

Diseño de escenografía: Ricardo Ricaño

Diseño de iluminación: Matías Gorlero

Diseño de vestuario: Fernanda García

Música original: David Ortiz y Ricardo Estrada

Elenco: Sara Pinet, Raúl Villegas, David Ortiz y Ricardo Estrada (músicos)

Fecha de presentación: 16 de noviembre de 2018

Lugar de presentación: Área 51 Foro Teatral 


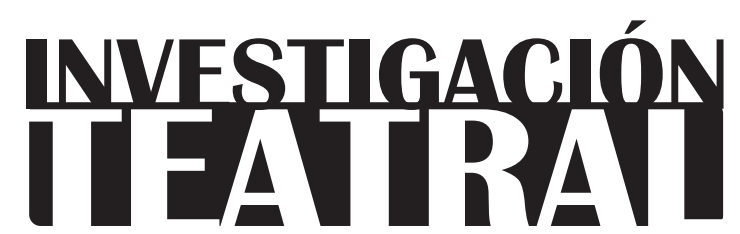

Revista de artes escénicas y performatividad

Vol. 10, Núm. 15

abril-septiembre 2019

Segunda época

ISSN impreso: 1665-8728

ISSN electrónico: 2594-0953

Universidad Veracruzana

\title{
Reseña del libro:
}

\section{¿Un mundo al revés? La tradición fársica en Hispanoamérica}

\author{
Disa Villada Montaño*
}

\footnotetext{
* Universidad Veracruzana, México. e-mail:disavillada@hotmail.com
}

Recibido: 19 de mayo de 2018

Aceptado: 18 de diciembre de 2018 


\section{¿Un mundo al revés? La tradición fársica en Hispanoamérica}

Dahlia Antonio Romero. ¿Un mundo al revés? La tradición fársica en Hispanoamérica. Xalapa/Ciudad de México: Universidad Veracruzana/Ficticia Editorial, 2017, 159 pp.

¿U $n$ mundo al revés? La tradición fársica en Hispanoamérica, de Dahlia Antonio Romero -editado en 2017, por la Universidad Veracruzana, en colaboración con Ficticia Editorial-, es el más reciente título de la colección Al vuelo de la risa, dedicada al estudio, desde diferentes enfoques, de la risa en la literatura. La autora presenta un ensayo acerca de la farsa, donde muestra un panorama histórico y analiza tres obras dramáticas hispanoamericanas: En la luna (1934), del chileno Vicente Huidobro; La última puerta (1934-1936), del mexicano Rodolfo Usigli, y Saverio el cruel (1936), del argentino Roberto Arlt.

Antonio Romero ofrece un trayecto por diferentes culturas y sus visiones del mundo, para poder entender los rasgos que sobreviven de la farsa antigua hasta la primera mitad del siglo xx en Hispanoamérica. Plantea que ésta conlleva una evolución a través del tiempo. El recorrido comienza con los griegos, quienes celebraban a Dionisio, dios de la máscara y la abundancia, que representaba no sólo la locura y la embriaguez, sino también la alegría. Su risa era regeneradora y, en buena medida, se dirigía a las autoridades a través de burlas. Esta civilización dio luz a la tradición fársica que después veríamos en las fiestas saturnalias de los romanos.

Las saturnalias celebraban a Saturno, dios de la agricultura. Sus festividades consistían en poner el mundo al revés: transformaban el día en noche, con las antorchas brillando a pleno sol; invertían los roles sexuales -los hombres podían vestirse de mujeres-; disolvían las jerarquías sociales y los esclavos podían darles órdenes a sus amos. Durante esta época, explica Antonio Romero, los latinos entrelazaban la risa con lo serio, reían con una risa cercana a la demencia, que se vio plasmada en el teatro de Plauto. A partir 
de este momento comenzó la censura de la comedia. El Estado prohibió que aparecieran personajes esclavos más inteligentes que sus amos, pues la tradición fársica se ha distinguido por mantener la utopía de la igualdad y la libertad, misma que se respiraba durante las festividades agrícolas.

Después, Antonio Romero nos sitúa en la Edad Media, donde los emperadores Teodosio y Valentiniano prohibieron las representaciones cómicas y el circo en días de fiestas religiosas y domingos, por lo que "la risa dionisiaca parecía haber sido vencida totalmente por una religión que coronó a su dios con sangre y espinas, que condenó la risa y la carne” (27). Continúa con el Renacimiento y el teatro de plaza pública de las compañías de la Commedia dell'Arte en la tradición fársica y, posteriormente, expone cómo los neoclásicos tomaron en cuenta la ventaja didáctica que el teatro presentaba para formar y enseñar valores y modos de comportarse, por lo que surgieron otros tipos de risa, como la satírica y la burguesa.

En este ensayo vemos cómo la farsa llegó al Nuevo Mundo, cómo se instauró en las colonias y qué papel desempeñó la figura del negro, junto con las demás figuras de la tradición fársica: los criados, bobos y simples del teatro español de los Siglos de Oro. Con el Romanticismo, el distanciamiento entre la seriedad y la risa, que había marcado la razón ilustrada, se desvaneció un poco; la tradición fársica recobró algo de su dominio con el teatro popular.

Al comienzo del Realismo, las imágenes de la tradición fársica se vieron como algo vulgar, como una risa banal, como una exageración de los aspectos negativos del hombre para corregirlo. Antonio Romero dice: "quizá la risa haya sido la mejor arma de los vanguardistas para poner al lenguaje, al arte, y al mismo mundo, de cabeza con el afán de renovarlo" (43). Asimismo, menciona lo que significó la obra de Alfred Jarry, Lbú Rey, debido a que Jarry planteó una renovación del teatro, como en los antiguos ritos dionisíacos, tras destruirlo; Ubú Rey sintetiza la tradición fársica. A causa de las imágenes fársicas que utiliza para exponer la separación entre el hombre y el mundo, junto con la crueldad y la violencia que imperan en la sociedad, se le considera precursor directo del teatro del grotesco italiano. ${ }^{1}$

En ese tipo de teatro, la risa renovadora de la antigua farsa es suplantada por una risa trágica, capaz de sonreír a pesar del dolor. En esta vanguardia -como en la Antigüedad- la risa y la seriedad no están separadas; empero, al transcurrir los siglos, el hombre cambia y, con él, sus expresiones artísticas. Principalmente, en el siglo XIX, cuando Friedrich Nietz-

1 Las técnicas de desrealización y distanciamiento presentes en Ubú rey se volvieron comunes en la farsa, que se interesó por mostrar al teatro como un espectáculo no mimético. Debido a ello, el recurso del teatro dentro del teatro fue muy bien recibido y tuvo repercusiones en los dramaturgos del llamado "teatro del grotesco italiano", principalmente en Luigi Pirandello, quien desarrolló esta metateatralidad en su obra Seis personajes en busca de un autor. 
sche le anuncia al hombre la tragedia de una vida sin sentido y lo enfrenta con lo terrible, surge una risa más sombría, cruel y sarcástica. La autora menciona: "se trasluce una perspectiva del mundo donde la risa ha perdido por completo su poder regenerador y es, más bien, el gesto grotesco con que el hombre saluda su completa inmersión en un mundo absurdo" (47).

Este amplio recorrido tiene la finalidad de situarnos en la primera mitad del siglo xx, en Hispanoamérica, frente a los grupos de teatro experimental que rescatan dicha tradición y conforman un frente revolucionario contra el teatro comercial. Antonio Romero pone como ejemplo a México, en donde la farsa se hallaba en las carpas, en los teatros portátiles que surgieron en los años 30, donde se dio a conocer a Cantinflas, quien popularizó una jerga absurda llamada "cantinflismo". La autora termina el estudio con el análisis de los textos de Huidobro, Usigli y Arlt.

El libro permite comprender el proceso de apropiación de la tradición fársica por parte de la alta cultura; asimismo, expone los elementos, las formas y tópicos que estas vanguardias intelectualizadas rescataron del grotesco antiguo y del romántico. Finalmente, la autora reflexiona en torno a una pregunta: ¿de qué se ríe la farsa hispanoamericana? Sus meditaciones apuntan hacia el carácter del sentido del humor; indagan acerca de si no podría ser éste una peligrosa evasión de sus circunstancias o si, por el contrario, es un arma de protesta. También especula acerca de la dificultad para encontrar una definición de la farsa, precisamente porque ésta evoluciona -junto con el pensamiento del hombreal paso de los siglos.

En general, en ¿Un mundo al revés? La tradición fársica en Hispanoamérica podemos encontrar el diálogo que existe entre la farsa y la historia, el papel de la risa -a través de sus diferentes facetas- como arma contra la opresión, con un objetivo extratextual que apunta alto: mover conciencias. Puesto que entre tanta injusticia y corrupción, "en Hispanoamérica la farsa es nuestro género más realista" (153), escribe Antonio Romero a modo de broma.

Con esta obra entendemos no sólo cómo cambia dicha propuesta estética a través del tiempo, sino también cómo evolucionan el hombre y sus ideas. Al alejarse de la Tierra -sus dioses, la fiesta de la fertilidad-su risa se oscurece y aparece separado del mundo, alienado a causa de las innumerables guerras y la tiranía de sus gobernantes. Es la historia de la transformación de la risa y la farsa. 


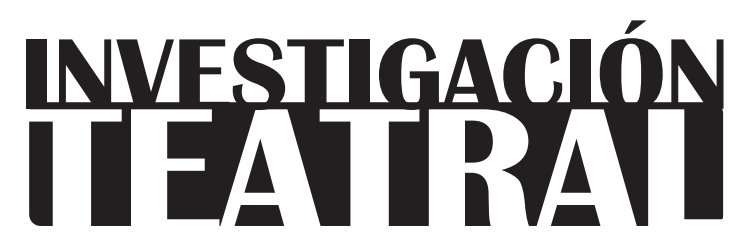

Revista de artes escénicas y performatividad

Vol. 10, Núm. 15

abril-septiembre 2019

Segunda época

ISSN impreso: 1665-8728

ISSN electrónico: 2594-0953

Universidad Veracruzana

\title{
Reseña del libro:
}

\section{Los objetos vivos. Escenarios de la materia indócil}

\author{
Marysol Arenas Cordourier*
}

\author{
* Maestría en Artes Escénicas, \\ Universidad Veracruzana, México. \\ e-mail:marysol130791@hotmail.com
}

Recibido: 12 de enero de 2019

Aceptado: 28 de febrero de 2019 


\section{Los objetos vivos.}

\section{Escenarios de la materia indócil}

Shaday Larios. Los objetos vivos. Escenarios de la materia indócil. México: Toma, Ediciones y Producciones Escénicas y Cinematográficas/Paso de Gato, 2018, 388 pp.

He comprendido la interdependencia de los objetos y la necesidad de colocarlos en determinada forma para evitar catástrofes o de cambiar súbitamente su colocación para provocar hechos necesarios al bienestar común.

Remedios Varo

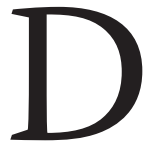
esde los cuartos de maravillas o gabinetes de curiosidades del Renacimiento, hasta las casas de antigüedades o los museos más imponentes del mundo, como el Louvre o el British Museum, los objetos han despertado el impulso animista primigenio de dotar de significado a la materia, de aprehenderla, de separarla de su origen común para poetizarla. La fascinación que producen los objetos ha dado lugar a numerosos estudios, que van desde las ciencias naturales hasta la filosofía, el diseño y las artes plásticas. La materia, convertida en herramientas, utensilios, juguetes, instrumentos, decoraciones y obras de arte, perdura, a veces de manera inconsciente, como testimonio físico de una época y de un lugar determinado.

Los objetos, inanimados per se, tienen una carga simbólica que les otorga una vitalidad latente que se reaviva cuando trascienden su carácter utilitario primigenio y dejan de ser utensilios antropomórficos o, en términos del teórico de los objetos Jean Baudrillard, cuando son poseídos. ¿Cómo enfrentar este oxímoron?, ¿cómo liberar a los objetos para dejarlos activar la memoria individual y colectiva? Si "un objeto vivo es un objeto desco- 
tidianizado, que mantiene una equidad conmigo o con otra persona" (Los objetos vivos 19), ¿de qué maneras podemos deconstruir esa jerarquía que nos coloca lejos, distantes de nuestros propios vestigios?

Estos testigos silenciosos, receptáculos de la memoria, son analizados en el libro Los objetos vivos. Escenarios de la materia indócil desde una perspectiva escénica multidisciplinaria a cargo de la creadora e investigadora mexicana Shaday Larios, quien ha dedicado su labor artística y académica a estudiar las correspondencias entre sujetos, objetos y contextos, como ella misma menciona, así como los vínculos entre memoria, entorno urbano y objetos cotidianos. El arduo trabajo de la autora parte del análisis teórico de sus propuestas escénicas en Microscopía Teatro y en El Solar, Agencia de Detectives de Objetos e incluye, en el último apartado del libro, textos de algunos creadores y sus proyectos representativos, como Jorge Vargas, Alejandro Flores, Ángel Hernández, Micaela Gramajo, Francisco Arrieta, Toztli Abril de Dios, Mariela Richmond, Irma Hermoso Luna, Caín Coronado, Xavier Bobés, Bárbara Bañuelos, Sara Pinedo, Rubén Ortíz, Ana Alvarado y Javier Swedzky.

En el teatro de objetos y en las teorías objetuales se hace referencia directa al surrealismo y a las exploraciones plásticas de Marcel Duchamp, quien fue uno de los primeros artistas que dislocó la forma en que eran percibidos los objetos cotidianos mediante los procedimientos del objet trouvé (objeto encontrado) y el ready made. Sin embargo, en muchas reflexiones se ha omitido a uno de los grandes artistas visuales que formó parte de esta revolución objetual: Giorgio de Chirico (1888-1978). Este pintor italiano siguió el pensamiento nietzscheano, así como el de Schopenhauer, en lo relativo a su noción de cosa, es decir, "la vivencia del objeto cual sensación desconocida antes que como útil" (62).

El libro consta de tres capítulos y un apartado con testimonios de poéticas de objetos documentales. En el primero, "Objetos poéticos. La mirada metafísica”, se desarrolla "la metafísica del objeto cotidiano", un análisis de la obra pictórica de Giorgio de Chirico con fundamento en diversos escritos que describen sus procedimientos. La presencia chiriquiana es un gran acierto por parte de la autora, ya que retoma el devenir cosa del objeto desde el punto de vista filosófico y visual, así como las interrelaciones entre ambas materialidades, y traduce esta poética a las artes escénicas objetuales. El proceso de esta transformación es la descontextualización del objeto (su soledad) y el objeto como generador de relaciones metafóricas (la aventura del sentido) (85).

El segundo capítulo, “Los objetos en la guerra. El Armario de Tadeusz Kantor”, está centrado en el trabajo del artista polaco y en el montaje de la obra En la pequeña casa del campo, de Witkiewicz, en 1961. Esta puesta en escena, perteneciente al periodo del Teatro Informal (1960-1961), se aleja de la representación en palabras y explora al objeto mediante juegos libres a partir del texto, de tal forma que el resultado fue una partitura 
de 19 acciones mínimas del objeto: un armario. El contexto post-catastrófico ${ }^{1}$ de Kantor está estrechamente relacionado con los periodos creativos de su obra y las interrogantes que invadieron la Europa de la posguerra respecto al arte, al fracaso de la Modernidad y a los objetos que se convirtieron en metonimias de los genocidios, en lo indecidible, en lo espectral: lo humano y lo inhumano, lo vivo y lo muerto. Además del trabajo de Kantor, en este capítulo se identifica un punto medular para la dramaturgia del teatro de objetos: la utilización de la partitura como sistema de notación de movimiento, ritmo e imagen que se asemeja más a una escritura procesual, en términos de la autora, y que será empleada por diferentes creadores de fines del siglo $\mathrm{xx}$.

En "Los objetos documentales dentro y fuera de escena", el tercer capítulo, se entretejen las reflexiones sobre De Chirico y Kantor para conformar una de las vertientes del teatro de objetos: el uso del objeto documental y el objeto etnográfico, que sigue el procedimiento metafísico del que se habla en el primer capítulo y está cargado de un contexto, como en la poética de Kantor. En este capítulo, Larios mantiene un diálogo abierto con la investigadora Diana Taylor a través de las nociones de archivo y repertorio para enriquecer esta visión de los objetos documentales, debido a que, "como fuentes archivísticas en potencia, se puede argumentar que su potencialidad justamente radica en ser un archivo vivo que incluye presencias que lo activan para hacerlo público" (259). Después del entramado metafísico, los objetos post-catastróficos y las técnicas etnográficas que apelan a los objetos como archivo vivo, se suma el concepto de realización escénica que desarrolla Erika Fischer-Lichte en Estética de lo performativo (2004), como el intercambio de presencias físicas entre actores y espectadores "en las que se hallan inseparablemente unidos lo estético y lo social o político" (Estética de lo performativo 89).

Este intercambio de presencias en y por medio de los objetos deviene en una nueva categoría del teatro de objetos documental, que Larios llama Dispositivos Cooperativos Objetuales (DCO). Un ejemplo de este tipo de montajes es la obra La máquina de la soledad, ${ }^{2}$ que realizó la autora con Microscopía y Oligor; contiene los preceptos teóricos anteriormente desarrollados: el encuentro del objeto (una maleta con más de 600 cartas de amor del siglo XIX), la abstracción de la "coseidad", así como el diseño y activación del dispositivo.

1 Larios propone la noción de post-catástrofe "como posibilidad de regeneración, como experiencia de confín, como generador de utopías hacia la re-invención de un nuevo mundo, como sensación capaz de ser traducida en una traslación poética hacia una figura compleja de horror-belleza. Por un lado, la idea de la materia post-catástrofe como punto de partida para la poetización de un pequeño todo que surge desde "eso" residual; por otro, la idea de catastrofización como categoría expandida aplicable a cualquier proceso creativo" (“El objeto 'post-catástrofe’ y la 'catastrofización' de la materia” párrafo 5).

2 http://lamaquinadelasoledad.org 
El capítulo final, "Testimonios. Poéticas de objetos documentales", está dedicado a la descripción y reseña crítica de algunos de los DCo de los últimos años. En las 12 micropoéticas y el anexo fotográfico es posible expandir las distintas maneras de acercarse a los objetos desde una perspectiva enriquecida por el universo de referentes que planteó la autora a lo largo del libro.

La lectura de Los objetos vivos. Escenarios de la materia indócil es clara y pertinente. Desde las primeras páginas se asientan los pilares teóricos y se distingue la metodología que detona una infinidad de preguntas estéticas, filosóficas y éticas sobre las posibilidades del objeto en un contexto artístico. La experiencia como creadora de Shaday Larios se vuelca en una reflexión teórica profunda que parte de sus propias inquietudes y resuena en diferentes artistas y estudiosos dedicados al análisis tanto del teatro de objetos como de figuras animadas. Este trabajo resulta indispensable para creadores e investigadores de artes escénicas, ya que subsana magistralmente uno de los rezagos teóricos en materia de poéticas objetuales contemporáneas y abarca, desde una visión multidisciplinaria, las problemáticas en torno a los procesos creativos, metodológicos y de escritura de un tipo de arte escénico tan peculiar como es el teatro de objetos, en su doble dimensión retórica y mnémica.

\section{Fuentes consultadas}

Fischer-Lichte, Erika. Estética de lo performativo. Madrid: Abada Editores, 2011.

Larios Ruiz, Shaday. Escenarios post-catástrofe: filosofía escénica del desastre. Cuadernos de Ensayo Teatral, núm. 19. México: Paso de Gato, 2010.

Larios Ruiz, Shaday. "El objeto 'post-catástrofe' y la 'catastrofización' de la materia. Preguntas y evidencias para un teatro de objetos documental". Titeresante. Revista de títeres, sombras y marionetas, Associació Interseccions, 10 de mayo de 2014, www. titeresante.es/2014/05/el-objeto-post-catastrofe-y-la-catastrofizacion-de-la-materia-preguntas-y-evidencias-para-un-teatro-de-objetos-documental-por-shaday-larios/, consultado el 6 de marzo de 2019. 


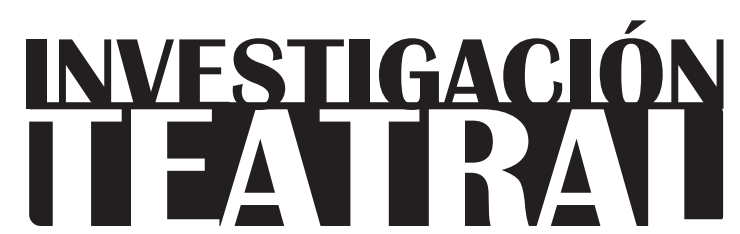

Revista de artes escénicas y performatividad

Vol. 10, Núm. 15

abril-septiembre 2019

Segunda época

ISSN impreso: 1665-8728

ISSN electrónico: 2594-0953

Universidad Veracruzana

\title{
Reseña del libro:
}

\section{Los payasos. Poetas del pueblo. El circo en México}

\author{
Carlos Gutiérrez Bracho*
}
* Centro de Estudios, Creación y Documentación de las Artes (CECDA), Universidad Veracruzana, México. e-mail: cagubra@gmail.com

Recibido: 13 de febrero de 2019

Aceptado: 20 de marzo de 2019 


\section{Los payasos. Poetas del pueblo. El circo en México}

De María y Campos, Armando. Los payasos. Poetas del pueblo, edición, apostillas y selección iconográfica de Sergio López Sánchez. Ciudad de México, Citru/InBA/Secretaría de Cultura, 2018, 416 pp.

$\mathrm{A}$ casi 80 años de que Armando de María y Campos escribiera Los payasos. Poetas del pueblo, el Centro Nacional de Investigación, Documentación e Información Teatral Rodolfo Usigli (CITRU), el Instituto Nacional de Bellas Artes (INBA) y la Secretaría de Cultura reeditan esta obra, cuya versión original es, como señala Sergio López Sánchez ${ }^{1}$ en el texto introductorio, "una verdadera rareza localizable sólo en unas pocas bibliotecas públicas y en algunas colecciones bibliográficas privadas" (13). Por lo mismo, dice López Sánchez -quien fue responsable de la edición, apostillas y selección iconográfica de la nueva publicación-, adquirió "una fama casi mítica" y su precio -el de aquella edición original- resulta, hoy en día, "bastante elevado" (ibídem). Sin embargo, la fama y "rareza" de este ejemplar no se debe, únicamente, al valor académico, literario e informativo que la obra en sí misma podría tener, sino porque, en las casi ocho décadas posteriores a su publicación, los estudios académicos en español dedicados al payaso son escasos, lo que es otra "rareza" debido a la aceptación -cada vez más creciente- que esta figura cómica tiene en la formación de artistas escénicos y público en general, no sólo de México, sino de varias partes del mundo.

¿Quién fue Armando de María y Campos? Este escritor, investigador, periodista e historiador nació en la Ciudad de México en 1897 y murió en ese mismo sitio en 1967. En La

1 Desde el año 2000, López Sánchez es investigador del CITRU; es, además, licenciado en Artes Escénicas para la Expresión Teatral por la Universidad de Guadalajara y, entre otros, ha publicado los libros Eraclio Bernal: de la insurgencia a la literatura (2012), Teatro Casa de la Paz: mudanzas en el tiempo (2011), y El Teatro Ángela Peralta de Culiacán Rosales: de trenes, tedio y espectáculos a fines del siglo XIX (2010). 
INVESTIGACIÓNTEATRAL

Revista de artes escénicas y performatividad

Vol. 10, Núm. 15

abril-septiembre 2019
Los payasos. Poetas del pueblo.

El circo en México

Carlos Gutiérrez Bracho

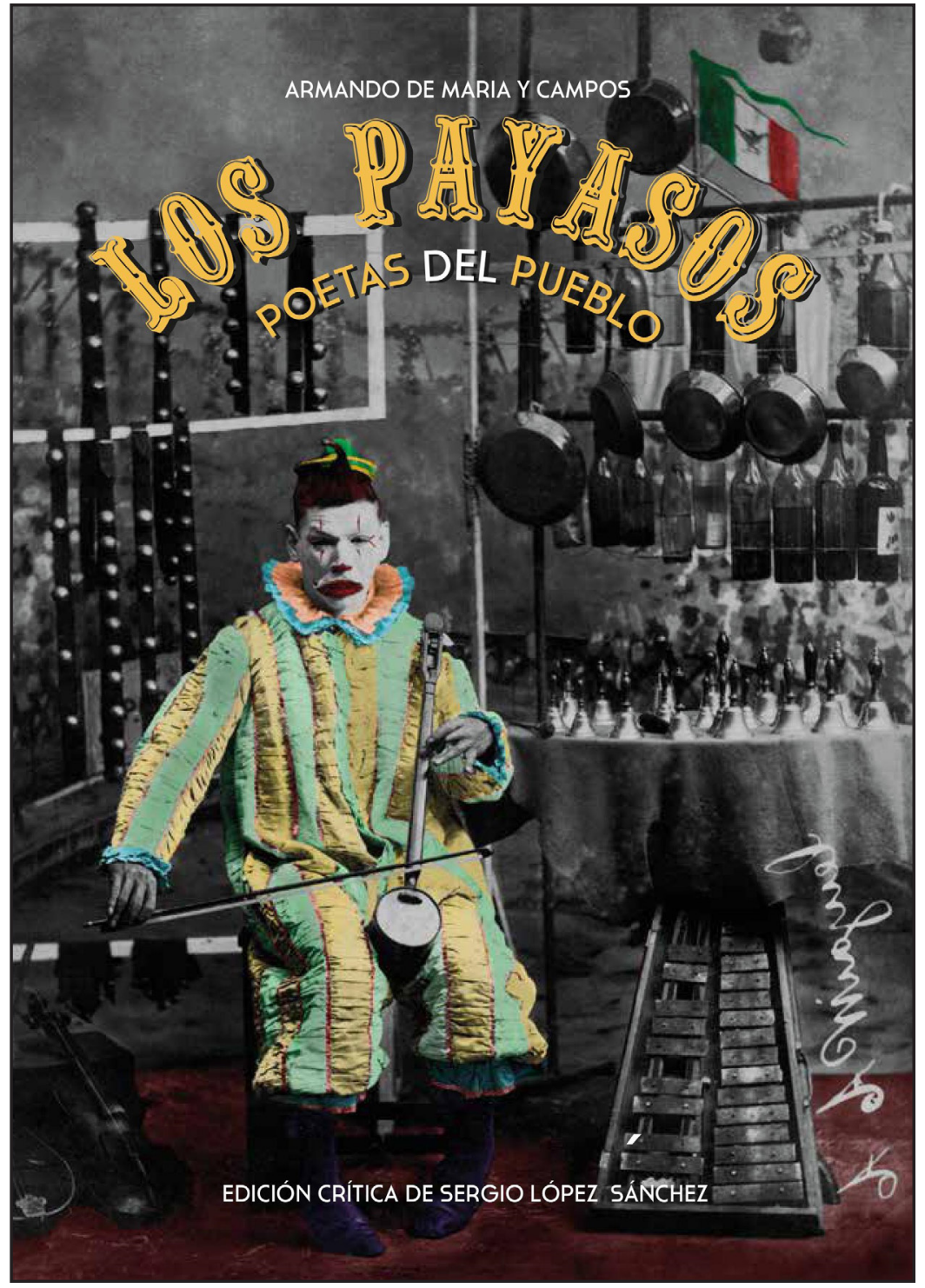

Andrés Atayde Guízar, el payaso "Miguel". Colección Andrés Atayde Guzmán. Cromatización digital de Josué Barrera. Cortesía del Citru.

literatura mexicana del siglo Xx, José Luis Martínez escribe que De María y Campos tuvo una enorme vocación por los espectáculos. Desde 1920 y hasta su muerte vio, "sistemáticamente", teatro, toros y circo, "en todas sus modalidades", es decir, “de género chico' o de revista y tandas, dramático, de títeres, radioteatro, teleteatro, óperas y conciertos"; también se dio a la tarea de "reunir libretos, programas y documentos [...] y a conocer la vida de toreros, payasos, actores, autores, empresarios, pioneros de la aviación y, sobre todo, a relatar 
lo mucho que vio, leyó y oyó con soltura y desenfado periodístico" (179). Publicó 81 libros, entre los que hay poesía, novela, biografías, ensayos, antologías y crónicas teatrales. Uno de ellos fue, precisamente, Los payasos, poetas del pueblo, editado en la Ciudad de México, por Editorial Botas, en 1939, cuando De María y Campos tenía 42 años de edad.

En su introducción a la nueva edición de Los payasos, poetas del pueblo, Sergio López Sánchez ofrece un estado del arte sobre los estudios acerca de los espectáculos que se realizaron en la Ciudad de México antes de que De María y Campos escribiera su libro. Se trata de Reseña histórica del teatro en México, de Enrique de Olavarría y Ferrari (1895); Historia del Teatro Principal de Puebla, de Eduardo Gómez Haro (1902); Historia del Teatro Principal de México, publicada por Manuel Mañón (1932), y Reseña histórica del teatro en la ciudad de Guadalajara, Jalisco, de Luis M. Rivera (1935). Tanto para la obra de Olavarría y Ferrari, como para el libro de De María y Campos, hace una aclaración pertinente: aunque ambos hablan de espectáculos realizados "en México", no se refieren al país, sino a la Ciudad de México. De María y Campos, para este libro, se interesó en "los artistas circenses populares, particularmente los payasos y el uso que hacen ellos del lenguaje español" (17).

En Los payasos, poetas del pueblo, advierte que López Sánchez, que Armando De María y Campos no realizó una investigación con estilo académico. Es descrita por el mismo De María y Campos como un "reportazgo retrospectivo de exploración y aventura del circo en México" (51), integrada por una serie de textos de carácter periodístico, en los que también muestra un marco histórico de la actividad circense a lo largo de la historia, como el nacimiento del circo contemporáneo en el siglo XVIII, "por un caballista inglés de nombre Bates" (53). Una novedad para la época en que fue editada la primera edición de Los payasos, poetas del pueblo, de acuerdo con López Sánchez, es el origen de buena parte de la información. De María y Campos usó, escribe, "una fuente de primerísima mano escasamente hasta entonces" (18): las tiras de volantes o programas de mano de los espectáculos de maroma y otros a los que asistió. Como periodista, cronista de toros y de teatro que era, se dedicó a coleccionar estos documentos, los cuales revelan información que de otra manera se hubiera perdido, porque "nunca llegó hasta los periódicos de su tiempo" (ibídem). Sobre su propia labor, De María y Campos escribió:

El material con que he trabajado esta crónica del circo en México lo forman los programas o convites que tan efímera vida tuvieron en su tiempo y que, sin embargo, supieron cautivar el alma del instante fugaz que les dio la vida. Únicamente cuando es indispensable recurro a la hoja periodística, al libro de la época, al testimonio del testigo presencial, como hilo precioso para zurcir los programas, más de un millar, que una paciente y jubilosa búsqueda me ha permitido acumular. A cada hallazgo, en una frase o en una estampa, sentía la emoción de rescatar al pasado un poco de su espíritu, 
de violar un secreto de la historia, que fue vida, que puede volver a vivir, resucitando, a poco que la caliente uno con su propio calor.

No he desairado ni uno solo de los papeles que pude hallar, porque todos, hasta el más insignificante, conservan una mueca, un ademán, una sonrisa del maravilloso espectáculo que anunciaron (51).

La edición original era de "una factura modesta, pero digna" (14); fue realizada con encuadernado rústico e ilustrada a cuatro tintas. El libro se vendió intonso, es decir, sus pliegos no estaban cortados y cada lector debía separar las páginas con un abrecartas. En su momento, la Editorial Botas publicó los textos de autores fundamentales en la historia de la literatura mexicana, como es el caso de Martín Luis Guzmán, José Vasconcelos, Mariano Azuela y Federico Gamboa, por citar algunos. En la edición que ahora ofrece López Sánchez se han agregado un glosario, para que el lector pueda reconocer palabras y términos escénicos/circenses que han quedado en desuso, así como un apartado de fuentes complementarias, en el que se encuentran las que sirvieron a la actual edición.

Además, como las direcciones de los centros de espectáculos de la Ciudad de México en el siglo XIX no se corresponden con las actuales, esta nueva edición ofrece una guía de cafés, calles, circos... con el fin de ayudar a reconocer la ubicación de viejos locales de espectáculos en la Ciudad de México de hoy; así, esta obra también muestra una panorámica de la gran cantidad de espacios dedicados a las artes escénicas y circenses de la capital mexicana. Asimismo, es de resaltar la colección de imágenes antiguas de la Ciudad de México, con lo cual se convierte también en un viaje visual al pasado de la metrópoli.

Aunque el texto original de De María y Campos aporta datos para reconocer actividades circenses desde la época prehispánica, hace falta precisión en algunas fuentes de información, lo cual deja dudas sobre su confiabilidad y rigor. Tampoco la nueva edición hace un estudio crítico sobre dichas fuentes y eso se echa en falta. Por ejemplo, basado en la Historia verdadera de la conquista de la Nueva España, de Bernal Díaz del Castillo, De María y Campos apunta que, a la llegada de Hernán Cortés, Moctezuma tenía enanos, bufones o payasos dentro de su corte. El texto no dice en qué parte, específicamente, Díaz del Castillo aporta esta información ni si los llamó de esa manera o si se trató de figuras similares a las que había en el Viejo Continente o qué las diferenciaba. De María y Campos también explica que los aztecas "presintieron" el circo como un deporte con significación religiosa; en este caso, se refiere a los "voladores" totonacos del norte veracruzano. Es poco preciso decir que dichos "voladores" hacían actividad circense, porque el circo contemporáneo surgió en el siglo XVIII y no tenía un carácter religioso.

Por otro lado, De María y Campos documenta la conformación del primer circo que se presentó en el Coliseo de la Nueva España. El programa de la primera temporada anuncia 
"bailarines de cuerda", que el mismo investigador no sabe si identificar como "equilibristas" y cuya indefinición no le es posible resolver debido a que no encontró ningún dato o referencia sobre su actuación en las gacetas coloniales. Cuenta cómo, en la esquina noroeste del Palacio Nacional y en otros sitios como el Portal de Mercaderes, a finales del siglo XVIII, se ponían carteles que anunciaban los espectáculos del Coliseo; ahí acudían los habitantes de la capital de la Nueva España para informarse sobre la programación. Estos carteles solían estar ilustrados con pinturas alusivas a cada espectáculo.

En ese tiempo, escribe De María y Campos, los eventos taurinos comenzaron a ser "invadidos" por actuaciones que eran ajenas a la lidia y que se llevaban a cabo durante el intermedio de la misma. Una de ellas "consistía en que un torero, el precursor del payaso o loco de los toros, llevando el traje que usaban los pobres dementes del Hospital de San Hipólito, provocaba a la fiera y se metía violentamente en una pipa vacía recibiendo ésta la embestida del bravo animal" (136). Asimismo, durante la primera mitad del siglo XIX, la antigua plaza de toros de la Alameda se convirtió en circo de equitación, con un espectáculo hípico-mímico-acrobático, donde la figura del payaso -ya indispensable en este tipo de actos circenses- entonaba "una canción popular".

Una de las presencias fundamentales de la escena circense de la capital mexicana en el siglo XIX, que documenta ampliamente el libro de De María y Campos, fue José Soledad Aycardo, "el más popular de todos los payasos mexicanos", que "resistió serenamente la competencia de otros también famosos payasos mexicanos y cuantos clowns extranjeros excursionaron de los cuarenta a los ochenta por la pista de la maroma mexicana" (94). Aycardo hacía pullas en verso y, en ocasiones, se presentaba con un vestuario ajustado al cuerpo, la cara enharinada y un cucurucho de fieltro en la cabeza. El programa de cada espectáculo de Aycardo era impreso en unas hojas que los asistentes podían recoger en la taquilla y estaba escrito en verso, porque este personaje también era poeta. Aquí un ejemplo:

[...] Un juguete volatín

de esta función es la guía

hasta dar el acto, fin, que será el trampolín por toda la compañía.

Mil vueltas darán en él en distintas posiciones pasando sobre un corcel disputándose el laurel danzantes y figurones. 
[...] Escenas más adecuadas

de circo, toman su lleno, pasando por las espadas que se le pondrán cruzadas al jovencito Moreno.

Vicente Torres hará muchas jocosas posturas, y a risa provocará pues las ejecutará con ridículas figuras [...]

Vengan pues a mi función damas, jóvenes, ancianos, niños, niñas, mexicanos, y los de toda nación.

Los llamo de corazón y a serviros no me tardo; no me claven ese dardo si no me hacen el honor que os pide su servidor José Soledad Aycardo (97).

Había otras compañías que competían con Aycardo. Entre ellas, estaba la de Antonio Pérez de Prian, donde se encontraba un gracioso llamado Trinidad Tamayo, quien cantaba poesía acompañado de su guitarra.

La obra de De María y Campos también da cuenta de cómo la vida circense mexicana no fue ajena a los acontecimientos políticos en esa centuria. En algunas ocasiones, como evasión; en otras, como una especie de víctima involuntaria de dichos sucesos. Por ejemplo, por la muerte de Melchor Ocampo, Santos Degollado y Leandro Valle, la sociedad en México vivía triste y aterrorizada, pero el pueblo "que sabe poco de política, engaña su hambre angustiosa concurriendo a funciones de volatín, equilibrios, gimnasia, voladores columpios, volteos y pantomimas" (189). O la lucha entre liberales y conservadores, que "arrancó de la maroma a no pocos maromeros, llevándolos a los campos de batalla" (203). También, cuando el archiduque de Austria aceptó la corona del nuevo Imperio, al Gran Teatro Imperial llegó una nueva compañía de circo integrada 
por acróbatas mexicanos; asimismo, con la llegada del Imperio, se dio en México una ola de "europeísmo" que invadió toda la metrópoli y desplazó de los teatros, quintas y patios, la maroma y el circo (215).

En 1867, llegó a México el circo europeo de Chiarini, que provocó "una evolución absoluta en la maroma mexicana", debido a la aparición en la pista mexicana del clown tipo inglés, con "pantalones bombachos, cara enharinada, peluca azafranada con tres cucuruchos de pelo en la frente, tonto de pista a la manera británica" (215). Se dio, pues, un desplazamiento del gracioso mexicano, que sólo aparecía en las funciones que se daban en la plaza de toros. A partir de ese momento, se llevó a cabo una invasión de circos extranjeros en las pistas del país. Es, también, según la explicación de De María y Campos, la presencia de compañías extranjeras la que hizo que el gracioso, paulatinamente, cambiara su nombre y apareciera el nominativo clown, para estas figuras cómicas. Para este investigador era importante reconocer el momento en el que el circo extranjero llegó a México, porque su presencia influyó para que la maroma mexicana perdiera "su fisonomía inconfundible" (229). En este terreno, tuvo un papel fundamental Ricardo Bell, "el gran payaso nacional" (231), quien conjuntó el humor británico y el ambiente mexicano.

A lo largo de las páginas que componen esta obra, se habla, precisamente, de cómo el gracioso mexicano vivió una decadencia física y artística, debido a la llegada del payaso europeo que, "logrando adaptarse al medio mexicano, acaba por ser el payaso nacional" (274). Asimismo, este texto no deja de mirar la conformación de figuras internacionales, como Grock o Chaplin, que también influyeron en la comicidad mexicana. No falta, por supuesto, una mención al que De María y Campos consideraba el "verdadero Polichinela mexicano": Cantinflas, uno de los máximos representantes de las carpas populares. Finalmente, a pesar de las imprecisiones que parece tener la investigación que realizó en los años 30 del siglo pasado Armando de María y Campos, no deja de ser un texto importante para conocer parte de la historia del humor popular en México, por tratarse, como se dijo al principio, de uno de los pocos textos que dan cuenta de la historia del payaso en México. Además, termina con varios escritos cortos de autores como Francisco Zarco, Fernando Orozco y Berra e Ignacio Manuel Altamirano sobre esta figura que es fundamental para la cultura mexicana del siglo $\mathrm{xx}$.

\section{Fuentes consultadas}

Martínez, José Luis. La literatura mexicana del siglo XX. Ciudad de México: Consejo Nacional para la Cultura y las Artes (Conaculta), 1995. 


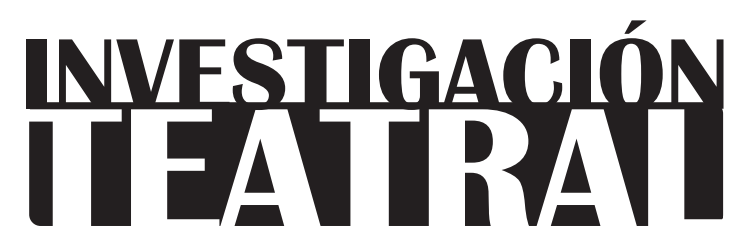

Revista de artes escénicas y performatividad

Vol. 10, Núm. 15

abril-septiembre 2019

Segunda época

ISSN impreso: 1665-8728

ISSN electrónico: 2594-0953

Universidad Veracruzana

Reseña:

\title{
La Muestra Estatal de Teatro de Chihuahua 2018: desmontajes y reseñas
}

\author{
Carlos Urani Montiel*
}

\footnotetext{
* Departamento de Humanidades, Universidad Autónoma de Ciudad Juárez, México.

e-mail: carlos.montiel@uacj.mx
}

Recibido: 11 de septiembre de 2018

Aceptado: 09 de enero de 2019 


\section{La Muestra Estatal de Teatro de Chihuahua 2018: desmontajes y reseñas} ace dos años y medio, un grupo de estudiantes y yo presentamos una iniciativa ante la comunidad artística y académica de Ciudad Juárez, Chihuahua: el Centro de Investigación y Documentación Dramática Norteatro. ${ }^{1}$ Nació por la necesidad de guardar y difundir la memoria del teatro escrito, producido y puesto en escena en el norte de México, en particular en nuestra localidad. Su portal (norteatro. com) sirve de archivo digital y plataforma para el estudio, discusión y enseñanza del arte dramático. El interés se concentra en la actividad escénica de una región que cuenta con una sólida tradición de dramaturgos, festivales, compañías e investigadores. Además de los contenidos que difundimos en internet y redes sociales -principalmente, reseñas de las puestas en escena-, interactuamos de forma directa con el público en varios escenarios y distintos momentos.

En el Festival Internacional del Drama Español Siglo de Oro, por ejemplo, antes de la función contextualizamos las obras que participan en este evento bifronterizo, el más antiguo dedicado al teatro clásico hispano. Acepté la invitación del municipio para ser juez en el 35 Festival de Teatro de la Ciudad, en julio de 2017; también entrevistamos -después del espectáculo- a los grupos artísticos que visitan la ciudad año con año en el Festival Internacional Teatro sin Fronteras, organizado por la compañía Telón de Arena. Recientemente, realizamos el Taller de Espectadores, un foro de convivencia y reflexión que sigue el modelo de la escuela fundada por Jorge Dubatti, en el que, a lo largo de 15

1 El colectivo se conforma por Amalia Rodríguez Isais, maestra en Estudios Literarios, así como por Karla Moreno Diego y Grecia Márquez García, licenciadas en Literatura. 
sesiones, compartimos experiencias y conocimiento con teatristas y gente siempre atenta a la cartelera local. Por último, la vinculación más importante -y que le da sentido al presente testimonio- fue la conseguida con la Secretaría de Cultura de Chihuahua para que Norteatro fuera parte activa, por segundo año consecutivo, de la Muestra Estatal de Teatro (MET).

En estas líneas pretendo realizar una revisión de la MET, a partir de una mirada crítica, asumida por el colectivo al que pertenezco. Así que, en un primer momento, reflexiono sobre la gestión en torno al diseño del programa, en donde se involucran cuestiones legales, de pertinencia y selección, previas a la inauguración, pero determinantes en el devenir de la MET. Posteriormente, desde la crítica teatral y como coordinador de Norteatro, recojo la experiencia del diálogo sostenido con las propuestas más interesantes: La luz de las ausencias, Apapacho, Por favor cierra la puerta, gracias y El caimán y los sapos. Las consideraciones finales sintetizan mis opiniones y sugieren recomendaciones en donde la labor de Norteatro busca consolidarse como un elemento constitutivo de futuras muestras.

Investigación, desmontaje y reseña crítica conforman las fases de un trabajo conjunto que atendió las nueve puestas en escena que participaron en la MET. Los desmontajes realizados frente al público, y con los miembros de cada compañía, fueron coordinados por los asistentes al Taller de Espectadores. Los desmontajes, opina Ileana Diéguez, aportan otros horizontes a quienes conciben "la teatralidad como un laboratorio para la configuración de los imaginarios sociales"; además del resultado, los teatristas comparten "procesos de búsqueda, investigación, entrenamiento y construcción, integrándolos en un evento artístico-pedagógico" (15-16). La asignación de las obras dependió del gusto y habilidades de los talleristas. El objetivo de la actividad se dirige hacia la exposición del trabajo previo de la puesta en escena: producción, propósito y limitaciones. En las entrevistas, investigación y creación dialogan a favor de la reflexión en torno al hecho teatral recién ocurrido.

\section{Gestión y curaduría}

Las Muestras Estatales de Teatro se han efectuado durante tres años continuos, gracias al impulso de un proyecto de alcance nacional de la Secretaría de Cultura en su nivel federal. Aunque la convocatoria es emitida por dicha institución -y se podría calificar de centralista-, los estados tienen la facultad de adecuarla a sus necesidades. Si, por un lado, las muestras contribuyen al fortalecimiento de la expresión dramática a través de una plataforma de exhibición de los grupos de cada entidad, por otro también debería 
existir un filtro - por medio de una curaduría cabal- que garantice que sean el receptáculo anual de lo más relevante de las escenas estatales. Ésa tendría que ser la consigna institucional. ${ }^{2}$ Reunir en un tiempo y espacio común "a la parte activa del teatro de todos los estados -opina Fernando de Ita- permite tener literalmente una visión individual y de conjunto del estado que guarda el teatro público por entidad, por región y a nivel nacional" (37).

En Chihuahua, esta iniciativa de difusión artística y congregación gremial celebró su emisión número 27, en 2018. En la pasada MET de Ciudad Juárez, 14 funciones, montadas por nueve compañías durante cuatro días, prometían un recorrido por las propuestas escénicas estatales. La dramaturga Maribel Carrasco, el gestor cultural y director Aristeo Mora, además del dramaturgo, director y ensayista Alberto Villarreal, conformaron el jurado, una tercia de buen nivel. Además de la exhibición, los montajes compitieron para llegar a la 39 Muestra Nacional de Teatro, celebrada en la Ciudad de México, en noviembre de 2018 -en donde Norteatro también se hizo presente, en la Muestra Crítica-, con una parada intermedia en la Muestra Regional de Teatro Noreste, en Tamaulipas.

Desde el primer día, me cuestioné sobre la impresión de los evaluadores ante la disparidad. ¿Pasmo, incredulidad, suspensión del juicio? Uno de ellos, Villarreal, afirma que "la naturaleza del teatro, en su accionar práctico y estético, es la desestabilización, sólo con esto se consigue vitalidad" (citado en Bujeiro, "El teatro como contrapeso" 92). El dictamen final se convirtió en intriga; no por la obra ganadora o la suplente, ya que la contienda recaía en dos o tres propuestas -aún menos cuando una quedó descalificada-, sino por los reconocimientos a director, escenografía, actores y dramaturgia. ¿De dónde escoger? Por fortuna, la deliberación no decepcionó. La premiación traía consigo apostillas y congojas para los organizadores. Los jueces, en aprecio a su tiempo y trayectoria, se desligaron de la planificación de la MET; incluso, informaron que, de las ocho carpetas participantes en la convocatoria - por ellos nunca consultadas-, fueron aceptadas todas, por lo que no hubo condiciones suficientes para deliberar sobre quiénes merecían reconocimiento individual. El escrutinio se hizo polvo y desierto.

Hubo grupos que decidieron no postularse. Me refiero a un par de casos que, aunque lejanos a las tablas, devinieron en la abstención. La comunidad artística estatal aún recuerda cuando, en la MET 2016, Hybris Teatro obtuvo el primer lugar con Lo que queda de

2 En su su reseña sobre la Muestra Nacional de Teatro 2017, celebrada en León, Guanajuato, Enrique Olmos de Ita dice que ésta funcionó "como un festival dado que la programación, desbalanceada en lo estético y geográfico, en realidad encarna las transitorias voluntades de un órgano colegiado (dirección artística), tal y como operan los festivales de artes escénicas comunes y corrientes, sin pretender una visión íntegra en excelencia o un recuento 'de lo mejor"' (párrafo 2). 
INVESTIGACIÓNTEATRAL

Vol. 10, Núm. 15

abril-septiembre 2019
La Muestra Estatal de Teatro

de Chihuahua 2018

Carlos Urani Montiel

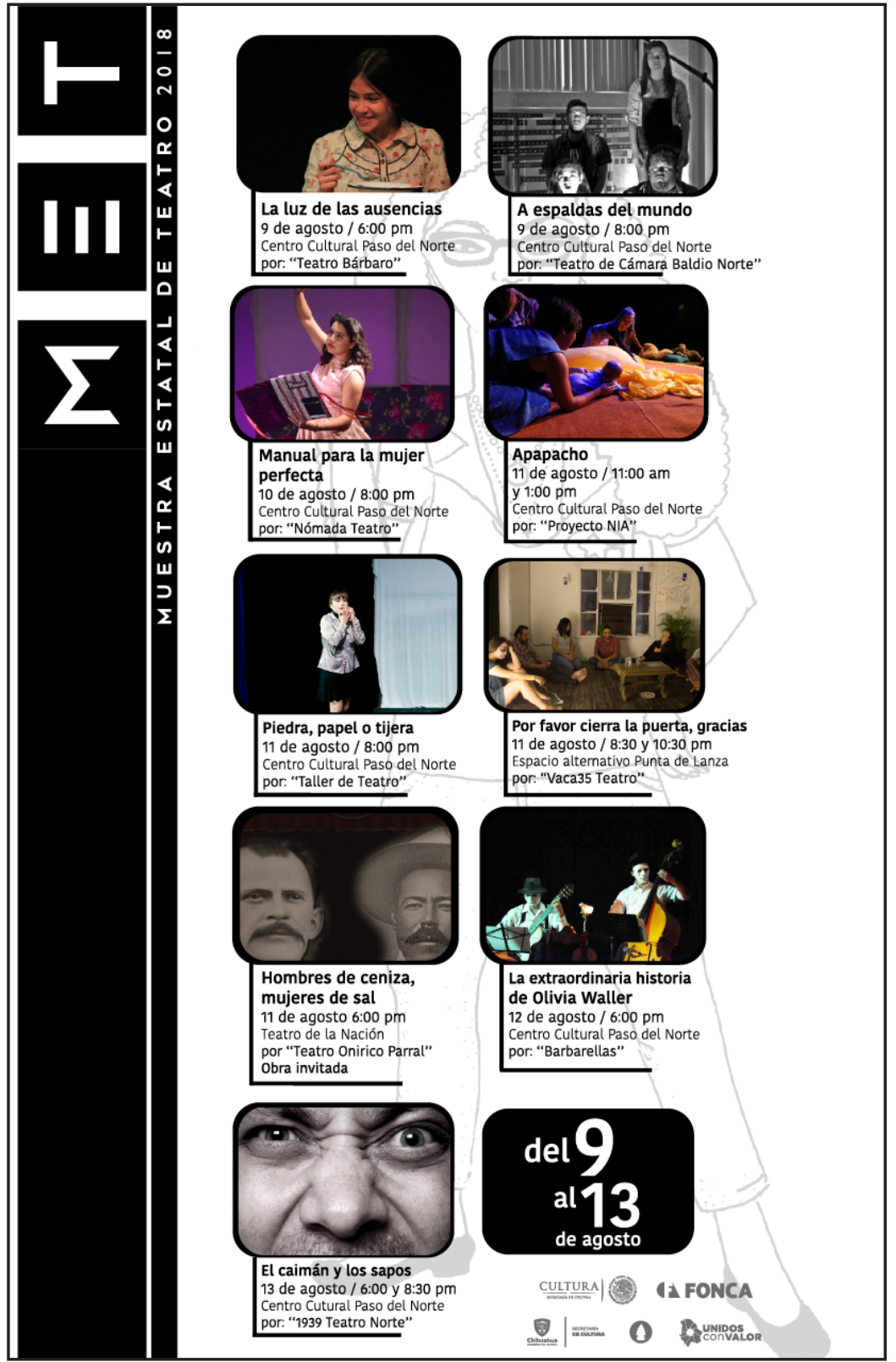

Programa de la MET.

Chihuahua, 2018.

Secretaría de Cultura.

nosotros, dirigida por Marco Martínez, pero - por cuestiones de derechos- la Coordinación de Artes Escénicas favoreció a la obra suplente, en vez de respaldar a los ganadores. La compañía, radicada en Ciudad Juárez, representa el paso a paso de un quehacer escénico original, independiente y profesional; a pesar de que su estreno fue extemporáneo, 
comprendo el desinterés. ${ }^{3}$ El otro caso es Telón de Arena, el grupo más longevo y numeroso en la entidad, que programa actividades culturales durante todo el año en su propio foro; como en la MET 2017 participó con cuatro obras y ahora la convocatoria señalaba que las "compañías y grupos teatrales podrían participar sólo con un montaje", su consejo artístico postuló tres (Río Ánimas, La señora Macbeth y Los de afuera), pero decidió no participar porque la cláusula sanciona la producción escénica en exceso. Con dichas omisiones, la MEт Chihuahua perdió su esencia. Estos hechos signan el trato de la institución con sus creadores y, así, el cometido de la calidad se puso en crisis en detrimento de toda línea curatorial.

\section{Teatro juvenil sin menores de edad}

La convocatoria restringe "montajes en cuyo reparto participen menores de edad"; la normativa también asienta que la "participación en la presente convocatoria implica la aceptación de las bases de la misma". Por ello, La luz de las ausencias, compuesta y dirigida por Saúl Enríquez, quedó descalificada. Esta obra es de Teatro Bárbaro, grupo artístico profesional de la capital del estado, que opera su propio foro y cuenta con el apoyo del programa México en Escena. La prohibición carece de sentido, pero no de claridad. ${ }^{4}$ Hace un año, la compañía presentó San Sipriano redentor y los Lágrima-team, de Raúl Valles, con un elenco incompleto, ya que el Niño Ladino era interpretado por un menor. Luis Bizarro, director de Teatro Bárbaro, desdeña las restricciones de carácter legal; incluso, confesó, durante la última premiación, que prefiere dar proyección y experiencia a su joven actriz Frida Serna -de 15 años-, quien dio vida al personaje de Tita en una obra "para toda la familia”, escrita especialmente para el grupo norteño.

En La luz de las ausencias, el peso de la marginalidad, la violencia en la sierra tarahumara, la discapacidad motriz del coprotagonista, León, así como el abandono de ambos padres, menguan ante una pregunta: “¿De qué estamos hechos?”. Tita y su hermano buscan

3 Las obras debían estrenarse entre el 1 de enero y el 13 de abril, fecha de lanzamiento de la convocatoria emitida por la Secretaría de Cultura del Estado de Chihuahua. Hybris Teatro estrenó Medio día, seguirá el mal tiempo, de Manuel Barragán, a finales de junio. En el Taller de Espectadores contamos con la presencia del director, Marco Martínez.

4 Concuerdo con Alejandra Serrano, quien ha documentado el teatro en los estados por más de una década, en su solicitud de revisión de las bases de las MET, sobre todo, para "evitar restricciones que son por demás absurdas" (37). Para más información, consultar su libro Teatro en los estados 2007-2017. 
averiguarlo. El motivo de la orfandad, recurrente en la dramaturgia de Saúl Enríquez, ${ }^{5}$ asola la vida de los protagonistas, quienes encuentran pequeños asideros en el quehacer cotidiano de la cocina o de la escuela rural. La sencillez del argumento, sostenida por un par de narradores siempre presentes, potencia varios planos expresivos, por medio de los cuales la puesta en escena se vincula con el espectador a través de la poesía, el olor, la música y el baile, además de una escenografía estática, pero multifuncional, sobre la que se aliñan metáforas de alto contenido emocional. ${ }^{6}$

Los narradores nos hablan desde un plano en el que ya todo ha ocurrido. Este orden cronológico-anacrónico (retrospectivo y a veces prospectivo) genera un distanciamiento frente a Tita y León, que delinea una atmósfera íntima para el relato oral. Sin embargo, esas figuras omniscientes que conocen motivaciones secretas y reflexiones privadas juegan otro papel. Además de enmarcar la fábula, pronto se corporizan e inciden en la escena, no de forma ilustrativa - es decir, no se hace lo que dicen-, sino que interactúan sutilmente con los personajes e incluso interpretan roles secundarios. Por otra parte, sus palabras no sólo narran sucesos espacio-temporales, sino que construyen imágenes poéticas a través del verso libre, paralelo al actuar de los hermanos: "Tierra adentro, / la sierra. / Adentro / se escuchan cantos. / Híkuri. / Medicina. / Silencio. / La obscuridad permite ver las estrellas como son, / más allá de su belleza; / León en medio de ella" (Enríquez). En un giro final y sorpresivo, los narradores abandonan la omnisciencia, develando su verdadero rol: testigos activos que desde el principio formaban parte del mundo de ficción, colaborando a que el saldo final en la historia sea positivo. ${ }^{7}$

El diseño horizontal de la escenografía se extiende de tal forma que acoge una estufa de carbón -recargada al extremo izquierdo-, y una amplia mesa de madera, en donde se sigue una receta -transmitida por la madre-, para preparar gorditas de trigo rellenas de chile con carne, sustento económico, a la vez que espiritual, de los consanguíneos. La preparación del alimento se convierte también en una secuencia que desprende aromas y colma

5 Así ocurre en Sie7e, de Nuca Merlot Teatro, y en La luz que causa una bala, obra ganadora de la MET Jalisco 2018. El fenómeno del abandono en la infancia se trata, según Enrique Olmos de Ita, "desde una perspectiva que no es popular, sino que alcanza profundidades oníricas y metáforas verdaderamente singulares" (párrafo 4).

6 A partir del desmontaje que realicé con la obra inaugural, redacté la reseña "Y ese es mi coraje", que se ocupa en exclusivo del concepto sonoro de La luz de las ausencias (2018).

7 La incertidumbre sobre la modalidad discursiva de la narración permite trasladar a la escena un perspectivismo múltiple, técnica que ha sido estudiada por José Sanchis Sinisterra, para quien las "afinidades y discrepancias entre el punto de vista del personaje narrador y el que la interacción dialogal proporciona al receptor constituyen una interesante fuente de ambigüedades y/o redundancias" (69). 
INVESTIGACIÓNTEATRAL

Revista de artes escénicas y performatividad

Vol. 10, Núm. 15

abril-septiembre 2019
La Muestra Estatal de Teatro

de Chihuahua 2018

Carlos Urani Montiel

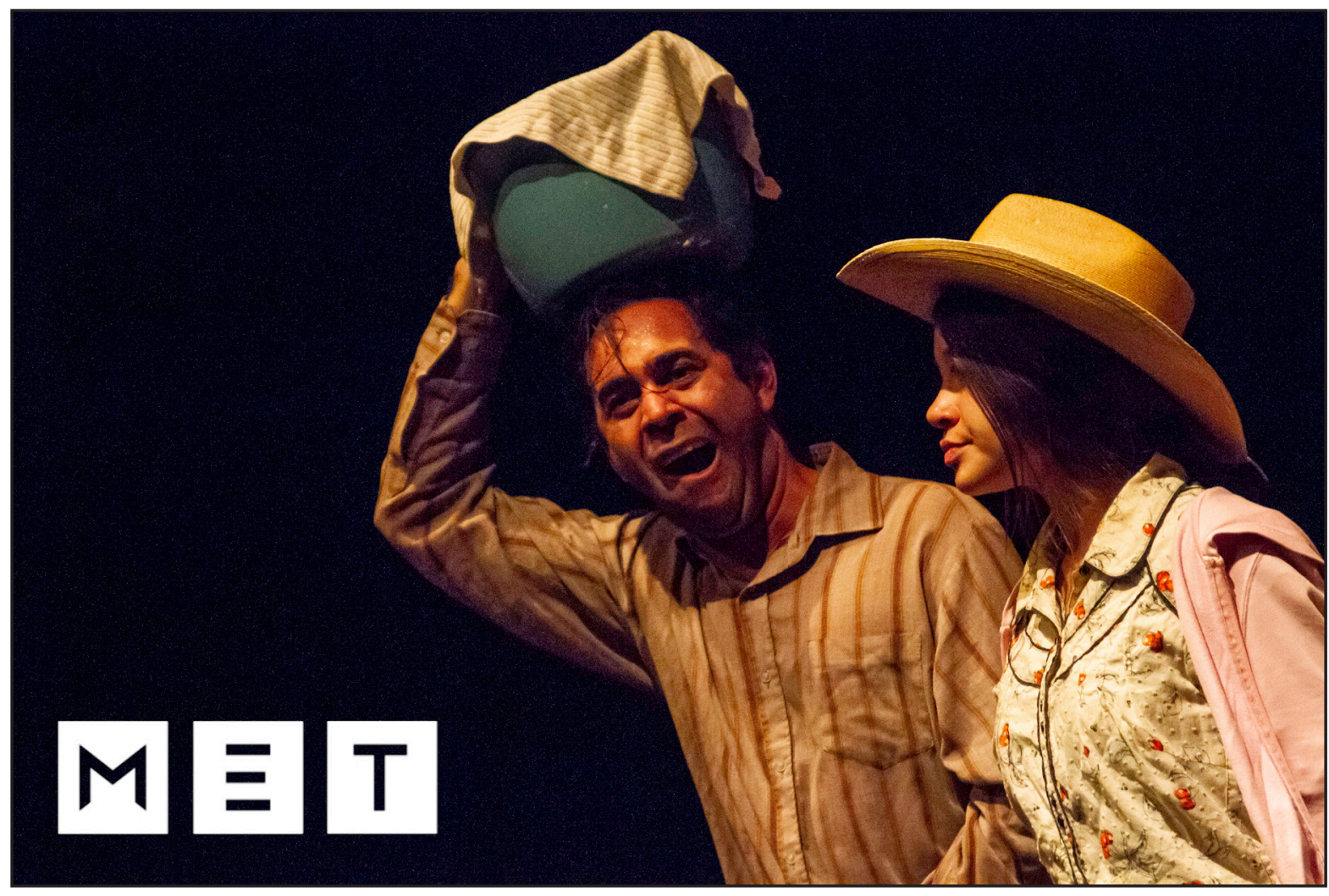

Teatro Bárbaro: La luz de las ausencias. 2018. Fotografía de Umberto Morales.

la sala de un calor hogareño al que tanto se aferran León y Tita. La luz de las ausencias conjuga el quehacer dramático de Teatro Bárbaro con la residencia de un director invitado; qué lástima que su emotividad y técnica no hayan sido recompensadas en la premiación, aunque sí en el teatro, que es lo que en verdad cuenta.

\section{Gatear en las tablas}

Desde que, en 2009, apareciera el libro Teatro para los primeros años, compilado por Wolfgang Schneider, las artes escénicas para la primera infancia - del nacimiento a los tres años- han cobrado auge y ya son una tendencia estable, por lo que cuentan con compañías y circuitos de representación especializados. En el teatro para bebés, los esfuerzos radican en la generación de vínculos comunicativos entre los artistas y los pequeños a partir de estrategias clave: escaso uso de lenguaje verbal, preeminencia de gestos y sonidos guturales, 
contacto visual, expresión y movimiento corporal como medios primarios de interacción. Estas habilidades se armonizan con el objetivo de provocar confianza, no sólo en los infantes, sino también en sus tutores, para que los primeros se involucren de lleno -con emoción, atención y cuerpo- en el espectáculo. ${ }^{8}$

Proyecto NIA, procedente de la ciudad de Chihuahua, participó en la MET con una doble función de Apapacho, dirigida por Nataly Muñoz Proo, quien desglosa su propuesta a partir del mismo título, como si fueran siglas: "Aprendizajes que Promueven Amor Para todos los que nos rodean. Abrazos del alma Con el cariño Hecho a la medida del Otro". El convivio inició en las afueras del Teatro Experimental Octavio Trías, en donde cuatro actores, caracterizados y a nivel de piso, dieron la bienvenida a los bebés, mientras que la directora, de pie, hacía lo propio con las mamás y los papás. Muchos asistían a este tipo de montajes por vez primera, así que había que aclarar las reglas del "juego escénico pre-conceptual" antes de ingresar a la sala: un cambiador inmediato a la entrada, un cartel con instrucciones que incentivaban el movimiento libre de los infantes: "Ellos deciden su participación, evitar forzar la interacción o limitarla".

Fernanda Avendaño, encargada del desmontaje, relata su experiencia: "Invitaban también a ejercer la lactancia materna con confianza y sin juicios, generando un espacio seguro para practicar la maternidad y paternidad de apego". El cuidado por el detalle promovió que el bebé explorara y disfrutara, "con su cuerpo, diversas formas sensitivas como el movimiento, los sonidos, los colores, la luz y las vibraciones" (Avendaño párrafo 2).

La expresión poética erigida sobre un escenario circular detona distintos estímulos sensoriales que atrapan al receptor. El papel que juega la audiencia traza una secuencia narrativa de afuera hacia adentro o viceversa porque, si bien existe cierta inercia argumental, resulta más potente la fuerza centrípeta que primero cautiva las miradas, pero que, conforme avanza el espectáculo y los histriones despliegan movimiento, atrae los cuerpos de los más ágiles y aventureros. El elenco entonces abandona el centro de la figura geométrica y rodea a unos nuevos personajes que recién experimentan las múltiples posibilidades de ser espectador.

Los jueces celebraron la propuesta de Proyecto NiA. De hecho, Maribel Carrasco escribe teatro infantil: Los cuervos no se peinan se escenifica por toda la República. Sin embargo, no entiendo por qué, si hubo un programa previo a la MET, compuesto por tres obras des-

8 Tras un compendio historiográfico, Evelyn Goldfinger concluye que "As the variety of theatre for babies productions illustrate, there is no single one way to design theatre for babies", ya que la audiencia responde de forma particular en cada parte del globo. No obstante, el proceso de producción sí presenta regularidades: "recalling the actors' personal experiences (as infants or with babies), watching baby videos, observing babies in relationship with their parents and/or conducting workshops with baby and caregiver audiences that are filmed and adults are asked for feedback" (296). 
tinadas a este público (MET Niños), no se incluyó ahí a Apapacho. Misterio insondable que seguro se reduce a una cuestión de papeleo o de cartera.

\section{Frontera creadora}

La condición fronteriza de Ciudad Juárez dicta acciones, rutinas y movimientos sociales propios de una vecindad, hecha unidad a fuerza de la interlocución entre distintas economías y modelos de habitar. Una madre, en el puente internacional, le desea suerte a su hija en su diario ir y venir al community college en El Chuco; una operadora apenas llega a tiempo a la parada de la ruta que la llevará al turno nocturno de la maquila; los locatarios, en las segundas de la Velarde, se gritan de una a otra acera; el mecánico halla en el tercer yonque la pieza automotriz que falta; los amigos se aposentan en esquinas, veredas o cruces en un habitual despliegue de historias singulares, que hacen del espacio fronterizo un escenario vital de intensas emociones. El teatro sabe recogerlas y las plasma en cuerpos que las revisten de añoranza.

Además de celebrar la nostalgia por una edad de oro bastante cercana, un eje de la obra Por favor cierra la puerta, gracias es la violencia como marca distintiva de la frontera; cada intérprete da cuenta de ella en sendos monólogos. En coproducción con el Laboratorio Escénico Teatro de Fronteras - perteneciente a Telón de Arena-, Vaca 35 de la Ciudad de México trajo a Juárez su proclama de “Teatro en grupo", cuyo sustento radica -como señala el director, Damián Cervantes- en la creación de espectáculos escénicos que dialoguen con el entorno y que propongan una reflexión profunda, tanto en actores como en quienes los miran a escasos centímetros. Por favor cierra la puerta, gracias encarna esta idea a partir de una dramaturgia colectiva próxima al biodrama que congregó las vivencias del elenco local.

Las historias individuales, llenas de soledad, melancolía, miedo y humor negro cartografiaron una metrópolis sitiada, pero con ganas de bailar y cantar. Antonio Rubio - quien dirigió el desmontaje- opina que la música de Juan Gabriel o de Los Silver "ayuda a crear esa atmósfera llena de nostalgia que se pretende evocar. En este caso, los actores no habitan estas espacialidades, sino que las exteriorizan por medio del recuerdo para combatir al horror" (párrafo 4). La obra se realiza en un espacio alternativo, donde la frontera se vuelve protagonista: la sala de un departamento céntrico en donde sólo caben 24 personas por función. Fue un reto trasladar el montaje, sin Ciudad Juárez como telón de fondo, a la Ciudad de México, en la Muestra Nacional de Teatro, en donde se presentó en la línea curatorial sobre testimonio, memoria e identidad.

Parece que el producto de toda residencia artística en la frontera debe girar en torno al (re)cuento de las víctimas. Cada vez que un grupo de creadores realiza una 
estancia en la ciudad, sin importar que haya juarenses involucrados, la violencia luce como tema, motivo o recurso retórico. ${ }^{9}$ Asumo la premisa de que el espíritu atiende experiencias límite con mayor presteza, respecto a actividades rutinarias; por tanto, estamos propensos a cargar de contenido emocional a los sitios donde esas vivencias ocurrieron y urdirlas en una secuencia narrativa que permite racionalizar y subsanar las secuelas. No obstante, y dando por hecho que en una reunión íntima de amigos no se relatan balaceras ni figuran anécdotas de encobijados, la violencia como eje expresivo es -y siempre será- una decisión, nunca una imposición, por más cruenta que sea nuestra realidad. Me parece que dicha resolución obedece a una tendencia institucional promovida por aparadores, premios y circuitos comerciales que socorren a creaciones que padecen -incluso enarbolan- el síntoma de la supervivencia. ¡Lo lograron! Salieron vivos de Juaritos y el mundo debe saberlo. Opino que existen otras formas discursivas que asumen la dignidad de la ciudadanía, aun y cuando recurran al retrato feral de nuestro norte. ${ }^{10}$

\section{Y la ganadora es...}

La MET bajó el telón con una doble función de El caimán y los sapos. La mancuerna entre la compañía 1939 Teatro Norte y la dramaturgia de Edeberto "Pilo" Galindo resulta tan natural en la frontera que sus producciones son garantía (Curva peligrosa, Acitrón de un fandango, Bubble Gum, En un tren militar, Filos y la futura De trapos corazón). Más allá del lazo familiar, existe una manera de componer que se expresa a través de un cauce en el que la sonoridad del diálogo, la materialización del entorno y el trazo escénico de cada secuencia potencian y enriquecen las palabras del dramaturgo, convirtiéndolas en acciones que apelan al espectador, al grado de que la respuesta emocional pareciera estar anticipada desde el texto dramático. Sin embargo, la escritura de "Pilo" Galindo, al carecer de acotaciones precisas, invita a que el ingenio del director - en este caso Abraxas Trías- configure un espacio propicio para que el auditorio sea uno con la trama.

9 Menciono tres ejemplos de distintas disciplinas: el cómic Viva la vida: los sueños de Ciudad Juárez, de Edmond Baudoin y Troub's (2011); la antología Road to Ciudad Juárez: crónicas y relatos de la frontera, compilada por Antonio Moreno (2014), y la puesta en escena Baños Roma, de la compañía Teatro Línea de Sombra (2013).

10 Como ejemplo, enumero otra terna: el poemario Juárez, tan lleno de sol y desolado, de Arminé Arjona (2004); Ciudad futuro, testimonio de Isaac Villa, "El Alas Blissett" (2012), y Fuenteovejuna, adaptación de Perla de la Rosa, escenificada por Telón de Arena (2017). 
Así ocurre en El caimán y los sapos, pieza documental que -tanto el título, como el dispositivo escénico y su adscripción a dicho género- involucra al receptor como comunidad o, en el peor de los casos, como cómplice. El docudrama extrae su asunto de un hecho real, lo que implica el embate del ámbito social dentro de la ficción. A mediados de 2013, Óscar Balderas publicó en el diario El Universal un artículo que combina la crónica periodística con el testimonio estremecedor de una joven víctima de la trata de blancas. "El Caimán, terror de trabajadoras sexuales en el DF" retrata la explotación de mujeres, muchas de ellas menores de edad, inmiscuidas en una red de corrupción donde operan varios agentes: captores, antros, "padrotes", poder judicial, altos funcionarios y aquellos quienes encubren el delito desde el silencio. La historia de Diana reconstruye la muerte de su "carnala" a manos de Ernesto, apodado "El Caimán": "El animal se comió a Andrea -recuerda su amiga y se estremece-. Te juro que esta historia es real; así castiga este desgraciado". El reportaje detalla el perfil del "sultán de Tenancingo", quien es una "maldad encarnada en un cuerpo moreno, fibroso [...] mirada demencial [...] habilidoso enamorador [...] no sólo es un proxeneta rico, sino uno amado, respetado, recolector de favores y sádico 'empresario"' (Balderas párrafo 23).

Si el documento periodístico constituye la base misma del texto dramático, su finalidad -noticia y denuncia- debía trasladarse a escena. El periodista asevera: "No es ficción, es un hombre real que [...] tiene víctimas en todo el país y que mata de miedo a las muchachas" (Balderas párrafo 14). La escenografía genera intimidad por lo limitado del rectángulo -tipo arena - cercado por 50 asistentes; también provoca fricción corporal, ya sea por la contigüidad entre las sillas o porque los actores transitan a través de corredores, detrás del público, y proyecta la sensación de encierro, obtenida con el plástico que nos confina a todos dentro de la caja negra. ${ }^{11}$ Yazmín Martínez, coordinadora del desmontaje, expresa su preocupación por "el hecho de no poder salir. En ese momento empezamos a sentir algo parecido al miedo de esas niñas, [...] una ansiedad ante la incertidumbre” (párrafo 2). El dispositivo escénico permite que la recreación de eventos se perciba tan próxima que el ejercicio de expectación se desestabilice, ya que no hay distancia entre el riesgo fingido y el desasosiego que incita. No sorprende, entonces, que al final, en pleno llanto, alguien se haya apresurado a abrazar a la actriz Laura Galindo, ni que una persona haya pensado que el desmontaje fue insensible por irrumpir el impacto de la obra, aun mucho después de los aplausos.

Criticar la propuesta de 1939 Teatro Norte parecería indolente, debido a lo duro del tema y a la conmoción que provoca. Uno podría argüir la relación directamente propor-

11 El capítulo "Público y expectación”, en El caimán y los sapos, de Edeberto "Pilo Galindo" estudia a detalle, y de forma comparativa, el montaje que aquí me ocupa, así como el producido por Teatro Bárbaro en la MET del año pasado (La puesta en escena y el espacio teatral 2017). 
INVESTIGACIÓNTEATRAL

Revista de artes escénicas y performatividad

Vol. 10, Núm. 15

abril-septiembre 2019
La Muestra Estatal de Teatro

de Chihuahua 2018

Carlos Urani Montiel

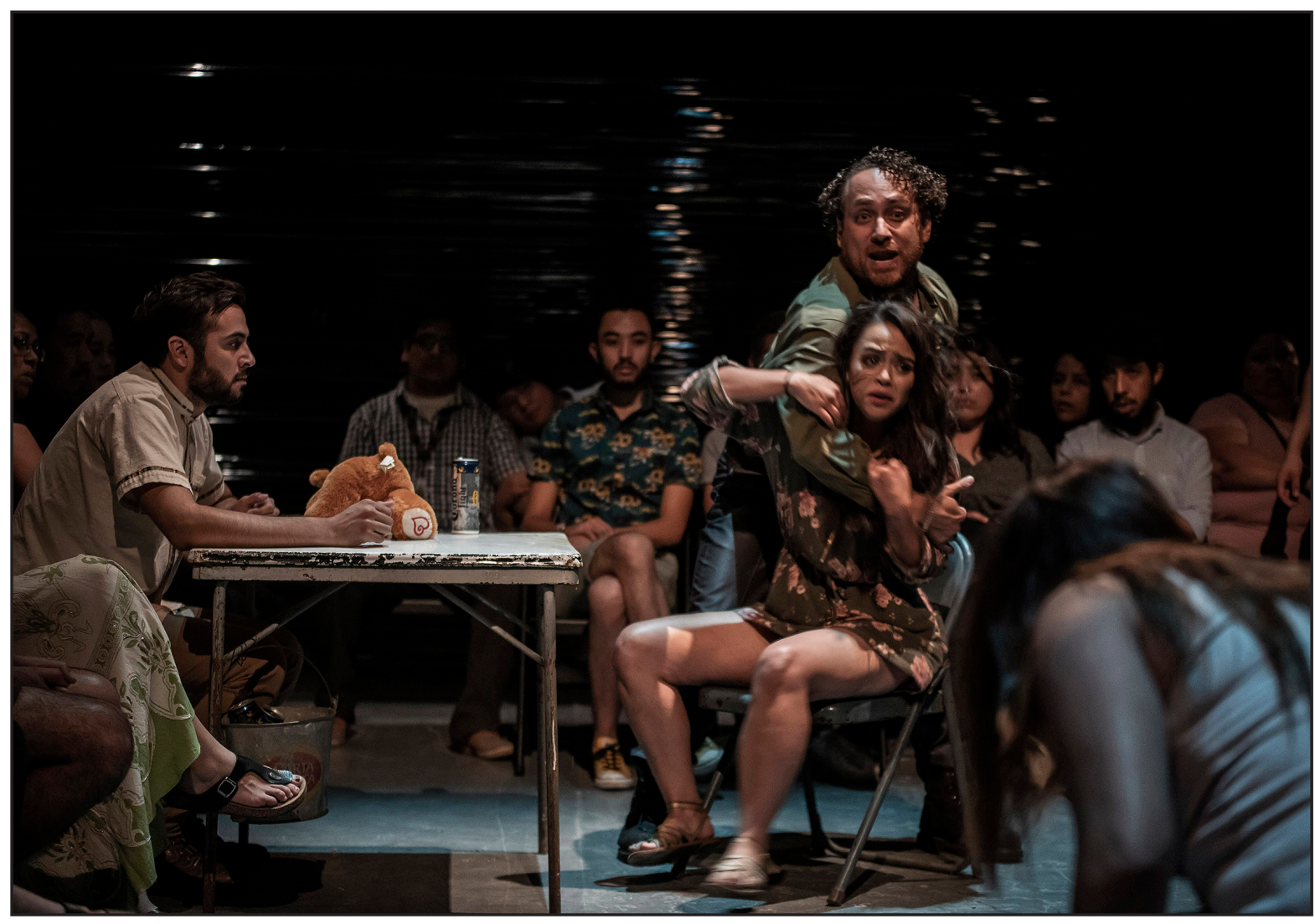

1939 Teatro Norte: El caimán y los sapos. 2018. Fotografía de Raúl Ramírez "Kigra”.

cional entre la violencia inherente al fenómeno y el furor con que se resuelven escenas cruciales; por ejemplo, cuando Andrea es sorprendida en la bañera y su amiga lucha porque no se la lleven. No obstante, el vals como metáfora de la tortura alega dicha apreciación. Por otra parte, aunque existe un personaje ajeno al tiempo de la fábula, es decir, el escritor que recoge el relato de la sobreviviente, su intervención no crea distancia, ya que durante la entrevista cede a la seducción de la informante y confiesa haber tenido tratos con una prostituta. Cuando esta figura, que esconde tras de sí la pluma del reportero o del dramaturgo, forma parte del problema, entonces el drama se concentra en la ficción y no en la reflexión. Un escritor en escena rompe la acción y apela a un cuerpo ajeno a los protagonistas, porque personifica la palabra, portavoz de una intención. Como esto no ocurre con el reportero de El caimán, el público se ve arrastrado por un torrente sensitivo que cancela su sentido crítico y demerita la reflexividad. Sin mediación o filtro, el observador olvida que la actriz representa, interpreta y cita. La crítica del teatro documental se expande cuando la fábula 
trastoca sólo a los personajes, al tiempo que reclama la interpretación del espectador ubicado afuera, aunque no ajeno ni inclemente, del universo representado.

\section{Consideraciones finales}

En la MEт 2018, celebrada en Ciudad Juárez, ${ }^{12}$ detecto dos rupturas: la de la normativa respecto a las condiciones locales y la de la Secretaría de Cultura, personificada por su titular Concepción Landa, en tanto que presume desinterés o desconoce las necesidades de los creadores. Ante ambas fracturas y el déficit a la respuesta de la convocatoria, las encargadas de Promoción y Difusión y de Desarrollo Cultural diseñaron un programa desequilibrado en contenido y pobre en calidad.

Frente a este panorama, ¿qué urge? ¿Cómo mejorar las siguientes emisiones? ¿Qué papel juega la crítica teatral? La cordialidad, el respeto y la transparencia me parecen clave para generar confianza y una línea horizontal de diálogo entre gestores y artistas. Un sitio web específico para la MET podría alojar y difundir la convocatoria -que cuesta tanto conseguir-, así como las carpetas de cada obra, los costos de realización y los tiempos de pago.

Lo primordial es una curaduría que dictamine las líneas generales del evento; sin ella, no hay esfuerzo ni inversión que valgan. Luz Emilia Aguilar Zinzer e Ilona Goyeneche consideran las MET "como un espacio para ejercitar la práctica curatorial -tan necesaria, pero aún tibiamente aceptada por el gremio, considerando ésta dentro de las posibilidades que permite el diseño mismo de las iniciativas estatales" (citado en Secretaría de Cultura del Estado de Jalisco 3).

En Chihuahua, en vez de nutrir el programa con los ocho postulantes, se pudo invitar a grupos profesionales para fortalecer el quehacer de agrupaciones emergentes en la entidad. Por otra parte, aunque con una incidencia plena, también es vital un marco jurídico que soporte la actividad de los teatristas. El problema se ha detectado año con año en el Encuentro de Creadores, pero las propuestas que de ahí emanan no trascienden en documentos oficiales. Urge revocar algunas cláusulas, como la referente a menores de edad, y apremiar que la convocatoria sea coherente con el teatro chihuahuense.

12 En el Encuentro de Creadores, celebrado en la ciudad de Chihuahua, a unos días de arrancar la Muestra, se enfatizó el adelanto en Jalisco respecto a los avances y fortalecimiento de su comunidad teatral. Norteatro viajó a Guadalajara para participar en el Laboratorio de desmontaje y de crítica abierta, coordinado por Luz Emilia Aguilar Zinzer e Ilona Goyeneche; esta sección también recoge lo vivido en la MET en tierras tapatías. Cabe mencionar que, de las 31 propuestas recibidas en Jalisco (de 50 cupos posibles), las curadoras seleccionaron 13 obras. 
Finalmente, ante la variedad de teatralidades, públicos y formatos, recomiendo rediseñar el formato de premiación. Los propios creadores, auxiliados por observadores externos -ya no como jurado-, pueden llegar a un consenso para designar la propuesta más representativa. A fin de cuentas, la MET es un encuentro que materializa, en una semana, el trabajo anual de todo un gremio. Procuremos este espacio en donde creadores, críticos, gestores y público celebran y atienden sus artes escénicas.

Cuando la institución administra recursos, también establece valores de legitimación. Por ello, Alberto Villarreal sugiere que la política cultural debería asumir una posición de dirección artística y no sólo administrativa, ya que el desarrollo de las teatralidades también se realiza desde la oficina ("El teatro como contrapeso" 93). Sobre esa directriz, la mirada crítica -al tanto de las condiciones de producción, lenguajes escénicos, objetivos y alcances de las propuestas- posee un gran potencial.

El Centro de Investigación y Documentación Dramática Norteatro asume con gusto y rigor la incidencia crítica sobre las puestas en escena. Durante los desmontajes, abrimos el diálogo no sólo con el público, sino con los teatristas, quienes aportaron su experiencia para vislumbrar el hecho escénico en su totalidad. Nuestras reseñas, además de guardar memoria de cada montaje, consideran el proceso creativo para reflexionar sobre lo que ocurrió en las tablas, en ese efímero momento en el que todos -gestores, creadores y espectadores- hacemos teatro.

\section{Bibliografía}

Avendaño, Fernanda. "Nanas, cariños y apapachos". Norteatro, Centro de Investigación y Documentación Dramática Norteatro, 15 de agosto de 2018, www.norteatro.com/ wp/nanas-carinos-y-apapachos, consultado el 30 de agosto de 2018.

Balderas, Óscar. “"El Caimán», terror de trabajadoras sexuales en el DF”. El Universal, 23 de julio de 2013, http://archivo.eluniversal.com.mx/primera-plana/2013/impreso/ el-caiman-terror-de-trabajadoras-sexuales-en-el-df-42583.html, consultado el 30 de agosto de 2018.

Bujeiro, Verónica. "El teatro como contrapeso. Conversación con Alberto Villarreal”. Letras Libres, núm. 181, 2014, pp. 92-93.

Diéguez, lleana. "Des/tejer, desmontar, de/velar. (A modo de introducción)". Des/tejiendo escenas: desmontajes. Procesos de investigación y creación, compilado por Ileana Diéguez. Ciudad de México: Universidad Iberoamericana, 2009, pp. 9-20.

Goldfinger, Evelyn. “Theatre for Babies: A New Kind of Theatre?”. Key Concepts in Theatre/Drama, editado por Shifra Schonmann. Rotterdam: Sense Publishers, 2011, pp. 295-299. 
Ita, Fernando de. "El estado de las Muestras". Teatro en los estados 2007-2017, editado por Alejandra Serrano. Ciudad de México: Teatro Mexicano, 2018, p. 37.

Martínez, Yazmín. "Gritos en silencio". Norteatro, Centro de Investigación y Documentación Dramática Norteatro, 27 de septiembre de 2018, www.norteatro.com/wp/ gritos-en-silencio, consultado el 30 de noviembre de 2018.

Montiel, Carlos Urani. "Y ese es mi coraje". Norteatro, Centro de Investigación y Documentación Dramática Norteatro, 11 de agosto de 2018, www.norteatro.com/wp/y-esees-mi-coraje, consultado el 30 de agosto de 2018.

Montiel, Carlos Urani. "Público y expectación en El caimán y los sapos, de Edeberto Pilo Galindo". La puesta en escena y el espacio teatral, compilado por Roberto Ransom Carty y Raúl Valles. Ciudad de México: Ficticia, 2017, pp. 259-271.

Olmos de Ita, Enrique. "Once momentos destacados de la Muestra Nacional de Teatro 2017". Letras Libres, 18 de diciembre de 2017, www.letraslibres.com/mexico/arte/ once-momentos-destacados-la-muestra-nacional-teatro-2017, consultado el 30 de agosto de 2018.

Rubio, Antonio. "Tócala otra vez, Onésimo". Norteatro, Centro de Investigación y Documentación Dramática Norteatro, 19 de agosto de 2018, www.norteatro.com/wp/ tocala-otra-vez-onesimo, consultado el 30 de agosto de 2018.

Sanchis Sinisterra, José. Narraturgia: dramaturgia de textos narrativos. Ciudad de México: Paso de Gato, 2012.

Secretaría de Cultura del Estado de Jalisco. MET Jalisco 2018. Programa de mano. Gobierno del Estado: Guadalajara, 2018.

Serrano, Alejandra. "Revisar las bases de las MET, tarea pendiente". Teatro en los estados 2007-2017, editado por Alejandra Serrano. Ciudad de México: Teatro Mexicano, 2018, p. 37.

Apapacho, de Nataly Muñoz Proo. Dirigida por Nataly Muñoz Proo, Proyecto NIA, agosto de 2018, MET Chihuahua, Teatro Experimental Octavio Trías, Ciudad Juárez.

El caimán y los sapos, de Edeberto Galindo. Dirigida por Abraxas Trías ,1939 Teatro Norte, agosto de 2018, MEт Chihuahua, Teatro Víctor Hugo Rascón Banda, Ciudad Juárez.

La luz de las ausencias, de Saúl Enríquez. Dirigida por Saúl Enríquez, Teatro Bárbaro, agosto de 2018, MET Chihuahua, Teatro Experimental Octavio Trías, Ciudad Juárez.

Por favor cierra la puerta, gracias, creación colectiva. Dirigida por Damián Cervantes, Vaca 35 y Laboratorio Escénico Teatro de Fronteras, agosto de 2018, мEт Chihuahua, Espacio Alternativo Punta de Lanza, Ciudad Juárez. 


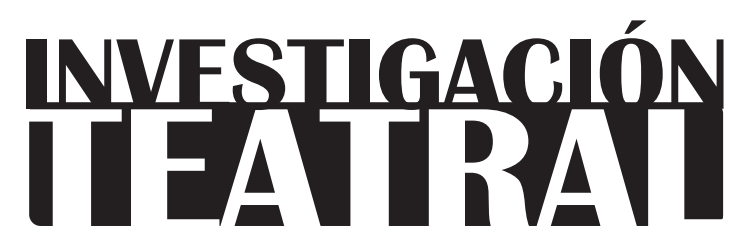

Revista de artes escénicas y performatividad

Vol. 10, Núm. 15

abril-septiembre 2019

Segunda época

ISSN impreso: 1665-8728

ISSN electrónico: 2594-0953

Universidad Veracruzana

In memoriam:

\section{Arturo Meseguer Lima (1956-2019)}

Francisco Beverido Duhalt*

\footnotetext{
"Centro de Documentación Teatral "Candileja", Xalapa, Veracruz, México.

e-mail: candilbever@yahoo.com.mx.
} 


\section{In memoriam:}

\section{Arturo Meseguer Lima (1956-2019)}

rturo Meseguer Lima era oriundo de la Ciudad México, pero vivió en Xalapa, Ve-
racruz, desde temprana edad, y descubrió el teatro cuando era adolescente. A prin-
cipios de los años 70, fue miembro fundador de la compañía Ateneum -el nombre con el que el director Raúl Zermeño, a su llegada de Polonia, re-bautizó la reestructuración de la Compañía de Teatro de la Universidad Veracruzana-, aunque no descarto alguna posible participación anterior, arrastrado por Enrique Pineda, en la efímera aventura de una carpa instalada en el Parque Juárez de la ciudad de Xalapa, donde se presentó por primera vez el monólogo La virgen loca, de Hosmé Israel.

Su primera participación como actor fue en Mazatecos (1975), una puesta en escena de Mario Alcántara, la cual se pretendía que fuera una reivindicación de ese grupo indígena. Desde ese momento, su dedicación, su interés y, sobre todo, su energía quedaron patentes, participando en todas las actividades que había en el programa de trabajo de la compañía: clases de teatro, de danza y de gimnasia. Desde ese momento, el teatro se convirtió en una de sus dos pasiones; la otra era el son jarocho, en el que se dedicó, con igual entusiasmo, a la jarana y al canto.

A pesar de ser parte del mismo grupo durante muchos años, tuvimos pocas participaciones conjuntas, aunque nos cabe el orgullo de haber sido parte del elenco de la primera obra de nuestra universidad en haber alcanzado - y develado una placa por- las cien representaciones: ¿Alguien dijo dragón?, de Carlos Lyra (1976), bajo la dirección de Jorge Castillo. Si bien mi personaje era el del galán joven -Juanito-, el verdadero protagonista era el personaje de Arturo -Tizón-, un niño mulato, a quien por esa razón todos discriminaban, incluso el Hada Madrina. 
INVESTIGACIÓNTEATRAL

Revista de artes escénicas y performatividad

Vol. 10, Núm. 15

abril-septiembre 2019
In memoriam:

Arturo Meseguer Lima (1956-2019)

Francisco Beverido Duhalt

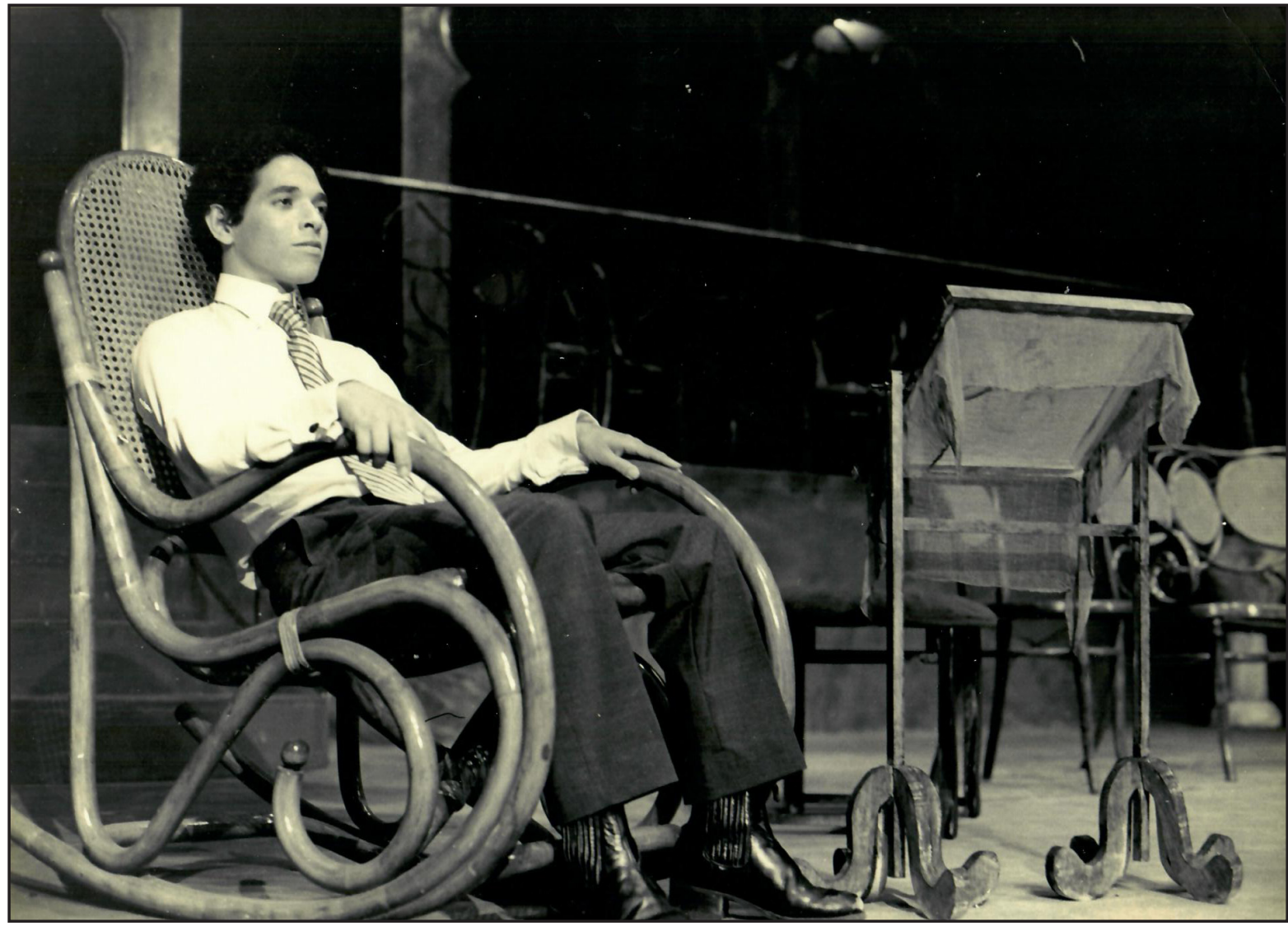

Arturo Meseguer en la obra El viaje superficial, de Jorge Ibargüengoitia, dirección de Raúl Zermeño. 1978. Foto cortesía de la familia Meseguer.

Volvimos a colaborar varias veces más: en La Atlántida, de Óscar Villegas (1976), y en Ivonne, Princesa de Borgoña, de Witold Gombrowicz (1978), ambas bajo la dirección de Marta Luna, así como en la memorable puesta en escena de Los signos del Zodíaco, de Sergio Magaña (1977). Pero sus papeles más importantes o más significativos fueron en otras obras: El viaje superficial, de Jorge Ibargüengoitia (1978), con dirección de Raúl Zermeño (donde su personaje hacía mancuerna con el de Enrique Pineda) y, sobre todo, en la inolvidable Los bajos fondos, de Gorki, dirigida por Julio Castillo (1979).

Más adelante, volvió a hacer mancuerna con Enrique Pineda en la efímera "Infantería Teatral”, desde su primera puesta en escena: Santa Catarina, de Óscar Villegas, en 1980. Si bien el grupo tuvo una duración muy breve, apenas cuatro años, logró algunas de los trabajos más importantes de aquella época para la universidad: Cúcara y Mácara (1980); 
La Ñonga, de Óscar Liera (1981); La última carcajada de Rosa Pérez, de Guillermo Garza (1982), y La pira, de Óscar Villegas (1983). Al regreso de Raúl Zermeño en 1984, quien reunió las tres compañías existentes, más los Talleres Libres de Actuación, en un solo grupo al que llamó Organización Teatral de la Universidad Veracruzana (Orteuv), se integró a ésta última y participó en muchas de sus puestas en escena importantes, entre ellas: ¿Cierren las puertas! (1988) y Veracruz, Veracruz, de Víctor Hugo Rascón Banda -estrenada en 1994, como parte de las actividades conmemorativas del Cincuentenario de la Universidad Veracruzana-.

No podemos olvidar su participación en Reflejos, un espectáculo de pantomima dirigido por Alejandro Morán en 1978, o en Los niños de otro planeta, una puesta en escena con títeres dirigida, ese mismo año, por Mercedes de la Cruz. Hay que mencionar, además, la experiencia de teatro experimental al aire libre de un taller impartido también en 1978 por Rense Royaards, del grupo Het Werkteatre de Ámsterdam, con la que Marco Antonio Montero buscaba ampliar los conocimientos y habilidades, así como diversificar las actividades de la compañía para no centrarlas en el teatro formal.

Si no me equivoco, su primer trabajo como director de escena fue en 1983 cuando, para celebrar un aniversario del espacio escénico "La Caja", se organizó una "Cruzada Teatral" por la ciudad, presentando varios espectáculos al aire libre. Uno de ellos fue El rey mono contra el demonio de hueso blanco (1983), un cuento tradicional chino adaptado y dirigido por Arturo con el Taller Coreográfico de la Universidad. A ella le siguieron, entre otras, $\mathrm{Ca}$ mino a Tokaido, de Dolly Velasco (1985); Cuento de navidad, de Emilio Carballido (1984); Octubre terminó hace mucho tiempo, de Pilar Campesino (1991), entre otras.

A principios de los 90, descubrió el Festival de Teatro Universitario e inició su actividad como funcionario: organizó de la edición XI (1986) a la XVI (1994). Fue por su iniciativa que, tras una interrupción de diez años y con el apoyo de los rectores Raúl Arias Lovillo, primero, y de Sara Ladrón de Guevara, después, la universidad retomó los Festivales Universitarios en 2012, de cuya organización se ocupó en los últimos años y que le incitó a organizar, con un esquema parecido, el Festival de Coros Universitarios, entre otras muchas cosas.

A pesar de ser abuelo -su hijo Camil, además de las satisfacciones de verlo como un músico profesional de alcances internacionales, le obsequió esa otra satisfacción-, Arturo nunca dejó de ser el eterno adolescente. Siempre fue "acelerado", "energético", vigoroso y vital; lo único que podía ponerle freno -a veces- era su disciplina y su rigor para todo lo que hacía, soñando y proyectando siempre nuevas cosas o cómo mejorar y superar las existentes. Aparentemente desperdigado, difuso, era capaz de concentrarse en varias cosas a la vez. Entregado no sólo a su trabajo, sino también a los que le rodeaban, participaba -en el mejor y más amplio sentido del término- con quienes compartían la escena con él. Muchos 
INVESTIGACIÓNTEATRAL

Revista de artes escénicas y performatividad

Vol. 10, Núm. 15

abril-septiembre 2019
In memoriam:

Arturo Meseguer Lima (1956-2019)

Francisco Beverido Duhalt

de los participantes en los casi diez festivales de los últimos años tienen presente su imagen cariñosa, entusiasta y su capacidad de liderazgo.

Arturo dejó inconcluso su proyecto de publicar una memoria por los 50 años del Festival de Teatro Universitario, al que adoptó con el mismo cariño con el que abrazaba todas sus empresas. No pudo completar su reto mayor -al que supongo que se le hizo difícil acostumbrarse-: la Dirección de Difusión Cultural de la Universidad Veracruzana, cargo que asumió en 2018. Su "acelere" le hizo adelantarse a muchos de nosotros y, por lo pronto, el Festival de Teatro Universitario ha quedado huérfano, mientras que la universidad ha perdido a uno de los personajes centrales de sus actividades culturales. 